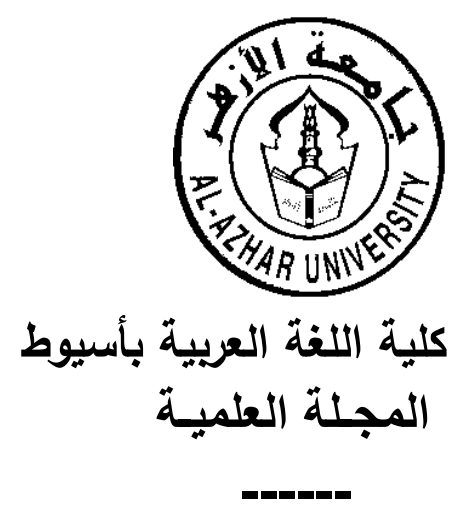

\title{
التــوجيـيـه الالغـوي
}

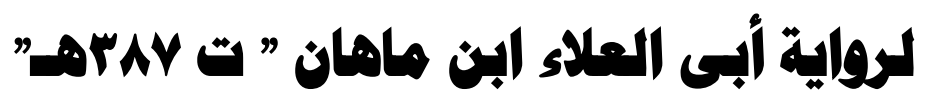 لأحاديث مصيح مسلم

$$
\text { إعداد }
$$

د/ سلامه عمر محمد عبد الرحيم

أستاذ أصول اللغة المساعد بكلية البنات الإسلامية بأسيوط

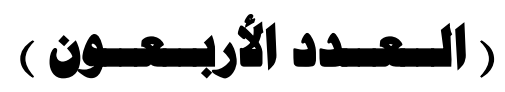

( إصـدار أكتــوبـر - البــري الأول )

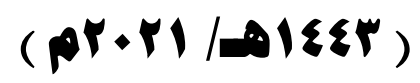




\section{التوجيه اللغوى لرواية ابن هاهان لأحاديث صميح هسلم}

سلامه عمر محمد

قسم أصول اللغة ، كلية البنات الإسلامية ، جامعة الأزهر ، فرع أسيوط. مصر البريد الإكترونى: SalamaAbdelrahem.el.8.473@azhar.edu.eg

|

أردت من خلال هذا البحث تسليط الضوء على رواية ابن ماهان لأحاديث صحيح

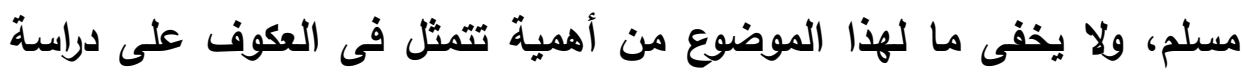

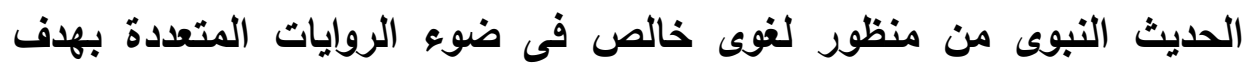

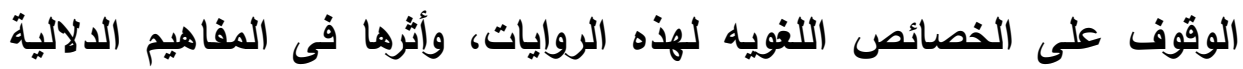

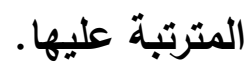
الكلهات المفتاحية: الرواية، الدلالة، الحديث، النبوي، التوجيه. 


\section{The linguistic orientation of Ibn Mahan's narration of the hadiths of Sahih Muslim}

Salama Omar Mohamed

Department, basic of language, Faculty of,Islamic Girls, Al-Azhar University, Assiut Branch, Egypt.

E-mail: SalamaAbdelrahem.e1.8.473@azhar.edu.eg

\section{Abstract}

Through this research, I wanted to shed light on Ibn Mahan's narration of the hadiths of Sahih Muslim. It is not hidden from the importance of this topic represented in the study of the Prophetic hadith from a pure linguistic perspective in the light of the various narrations with the aim of identifying the linguistic characteristics of these narrations, and their impact on the semantic concepts arising from them.

Keywords: Novel, Semantics, Prophetic, Hadith, Orientation 


\section{|لمبمقدمبة}

إن الحمــ لله خلق الإنسـان علمـهـ البيـان، والصـلاة والسـلام على سيدنا محمد أفصح الناطقين، وعلى آله والتابعين.

\section{9-10}

فـلا يـزال الحديث النبوى الثـريف مـوردًا عـنبًا ومـنهلاً رائقـا للعديــــن

الدراسات، ويأتى فى مقدمتها تلكك الاراسـات التي تعنى بلغته على جهة بيان ألفاظه واستكناه معانيـه، ومن هذا المنطلق اخترت للاراسـة والبحث روايـة من روايـات صحيح الإمـام مسـلم بن الحجـاج، وهـى روايـة أبـى العـلاء ابن ماهـان

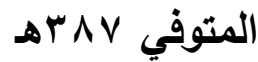

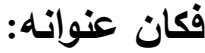

\section{"التــوجيسه الانفوي "}

\section{لرواية أبى العلاء ابن هاهان ت rAr هـ لأحاديث صميح مسلم}

ولا يخفى مـا لهذا الموضـوع من أهميـة تتمثل في العكوف على دراسـة الحديث النبوي من منظور لغوي خالص فى ضوء الروايات المتعددة التى حفلت بها بطون مصنفات شراح الحديث. بهذف الوقوف على الخصائص اللغوية لهذه الروايات وأثرها فى المفاهيم الدلالية المترتبة عليها. وقد تعددت الدوافع الباعثة على اختياري لهذا الموضوع وتحددت في عدة

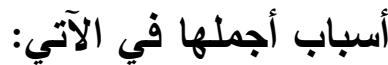

أولا: التأكيد على أهمية دراسـة الحديث النبوي من جميع جوانبه بوصفه

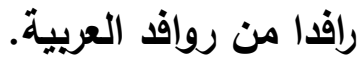


ثانيا: إماطة اللثام عن رواية ابن ماهان لصحيح الإمام مسلم باعتبارها

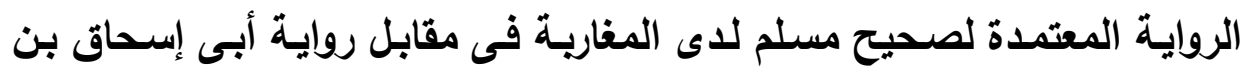
سفيان عند المشارقة.

ثالثــا: اثـتمال روايـة ابن ماهـان لصحيح الإمسام مسلم على كثير من الظواهر اللغوية التي تغري بجمعها ودراستها.

رابعا: خلو المكتبة العربية من مصنف يعنى بإبراز التوجيه اللغوى لرواية ابن ماهان لأحاديث صحيح الإمام مسلم.

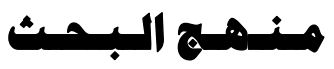

اتبعت في دراستي هذه المنهج الوصفي التحليلي، وقد انتظم المنهج الذى سرت عليه ف عدد من النقاط على النحو الآتي:

1ـ استخراج الروايات المعزوة لابن ماهان من المصادر المختلفة، والتى

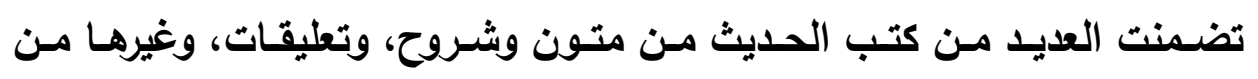
مصنفات يظن وجودها فيه.

r - تصنيف الروايات المجموعة تحت مباحث كلية وفق مستويات الدرس اللغوي الحديث " الصوتية والصرفية والتركيبية والدالية "

r بـ دراسـة لغويـة تحليليـة لروايـات ابن ماهـان مقارنـة بالروايـات الأخرى

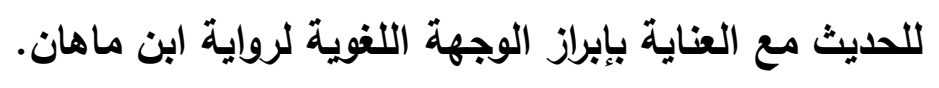
هذا. ... وقد اقتضت طبيعة البحث أن يصدر في مقدمة وتمهيد وأربعة مباحث تليها خاتمة وثبت بفهارس المصادر والمراجع. ففى الاقدمة: تحدثت عن أهمية الموضوع ودوافع اختياره، والمنهج المتبع فيه. 
أهـا التمهيــ فعنوانه " صحيح مسلم ورواية ابن ماهان " وقد عقدته للحديث عن الإمام مسلم، وصحيحه، ورواية ابن ماهان لأحاديثه.

\section{المبمث الأول: المستوى الصوتي}

وضمنته الحديث عن أهم مـا اشتملت عليه رواية ابن ماهان من قضايا صوتية كالهمز وتسهيله، والإدغام، والإبدال الواقع بين الصوامت اللغوية. المبشث الثاني: المستوى الصرفي

وفيه الحديث عن أهم مـا اشتملت عليه روايـة ابن ماهـان من خصائص

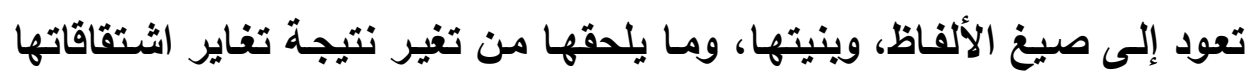
اللغوية.

\section{المبمث الثالث: المستوى التزكيبي}

وتناولت فيه عددًا من المسائل التركيبية الواردة في رواية ابن ماهان.

\section{المبمث الرابع: المستوى الدلالي:}

وفيه أهم المباحث الالالية التي أفززتها روايـة ابن ماهـان مقارنـة بغيرهـا من روايات الصحيح.

\section{الفاتمة: وفيها أهم النتائج التي كثف عنها البحث.}

فهـرس المسـادر: وتضمن أهم المصادر التي رجعت إليها من المصنفات

العلمية.

هذا ومـا كـان من توفيق فمنهـ سبحانه وتعالي، ومـا كان من تقصير فحسبي

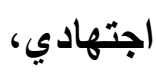

وآفر دعوانا أز الهمد لله رب العالمين. 


\section{التمهيد: صميح مسلم ودواية ابن ماهان}

\section{أولا: الإمام مسام وصميحه

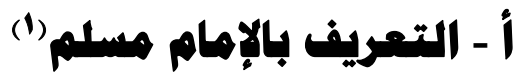

الإمام مسلم بن الحجاج القشيري صساحب المسند الصحيح أعرف من أن

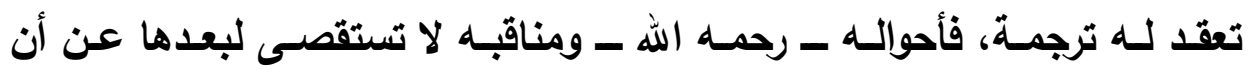
تحصى، لكني أكتفي هنا بإضاءات من حياة ذلك الإمام فأقول

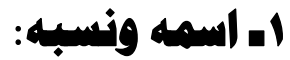

" هو الإمام المحدث الثقة الحافظ: مُسلم بن الحجاج بن مسلم بن وَرْد ابن

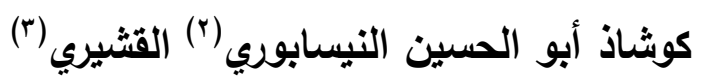

\section{r مهولده وحياته:}

أجمـع العلمـاء على ميلاده بعد المـائتين للهجرة، وإن اختلفوا في تحليد سنة ميلاده، فقيل سنة أربع ومائتين (؛)، وقيل سنة ست ومـائتين للهجرة النبويـة

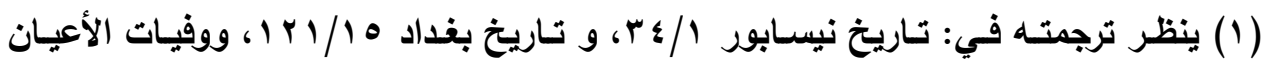

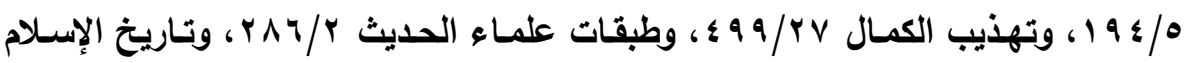
$. \varepsilon r \cdot / 7$

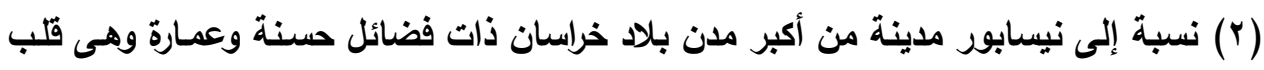

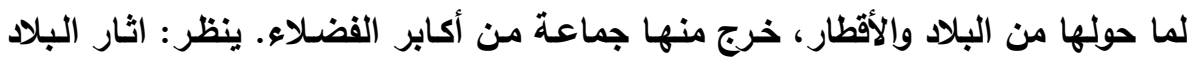

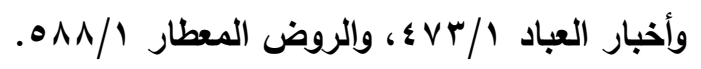

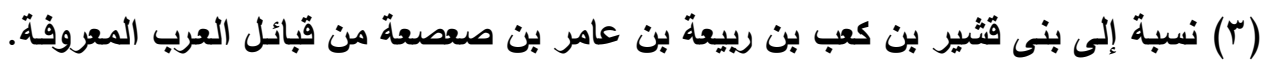

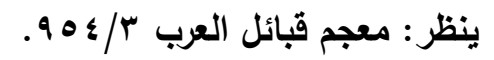

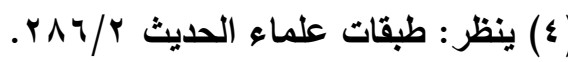


المشرفة(1)، وعلى كل حال فإن العصر الأى عاش فيه الإمام مسلم يعد من أزهى

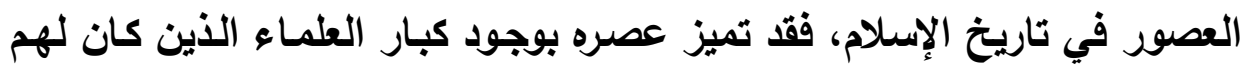
بالغ الأثر في خدمة السنة النبويـة والمحافظة عليها بتدوينها كالإمـام البخاري

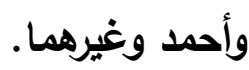

وعلى هلى من تقدمه من التابعين وتتابعيهم فقد نشأ الإمـام مسلم رحمـهُ

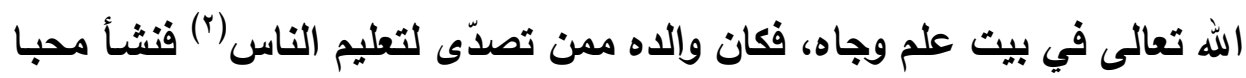

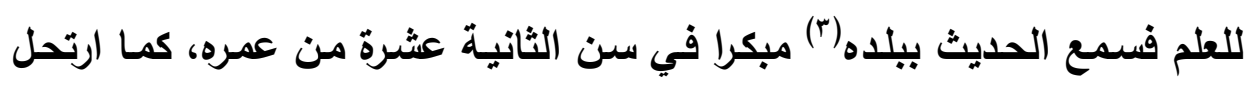

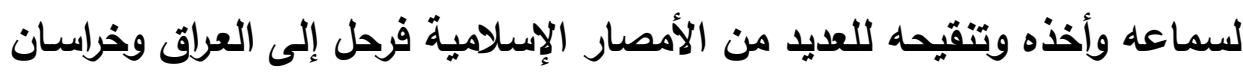

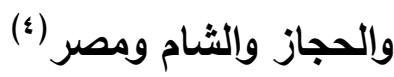

فسمع بدمشق محمد بن خالد السكسكي (ت IV IVA)، وسـمع بخراسـان

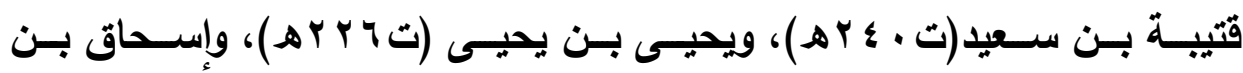

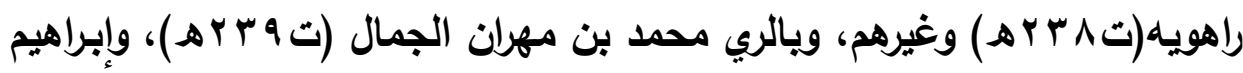

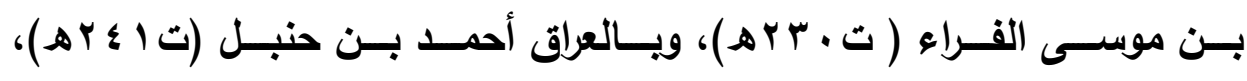

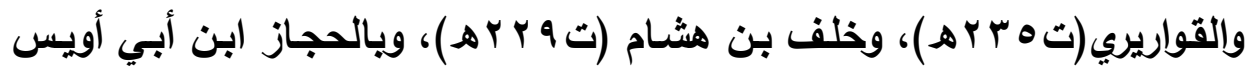

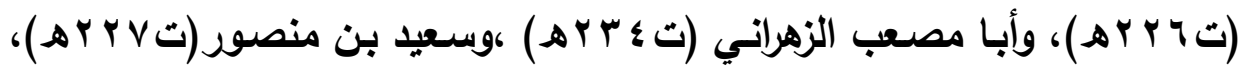

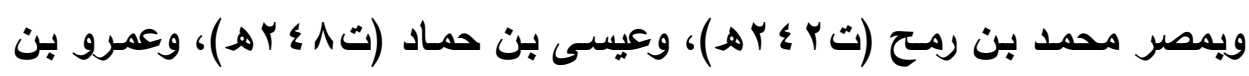

(1) وهو ما رجحه ابن خلكان. ينظر : وفيات الأعيان 190/0.

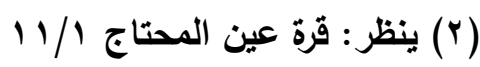

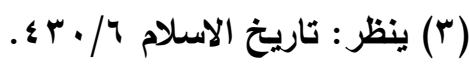

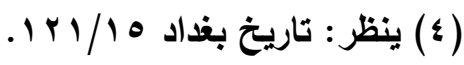


سواد(ت ه ؛ Y هـ) وغيرهم، كما دخل بغداد وسمع من أهلها (') وقد سمي المزى

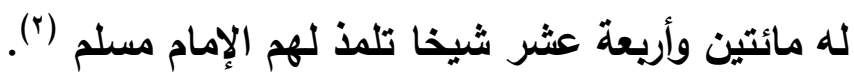

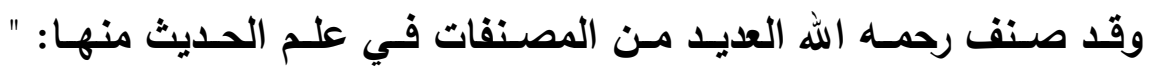

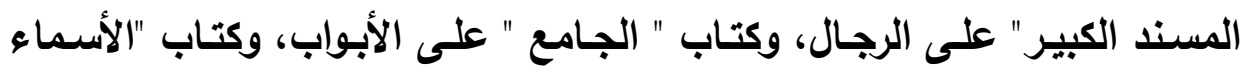

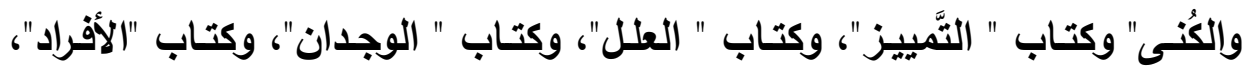

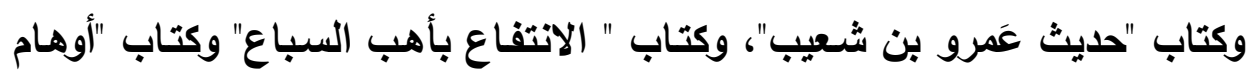

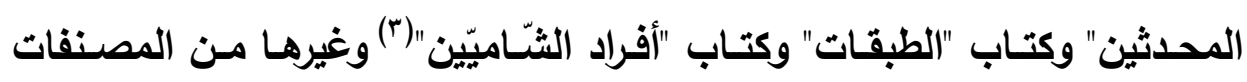

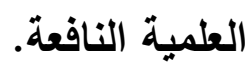

\section{rه هكانته وأقوال العلمهاء فيه:}

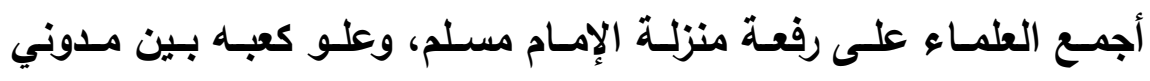

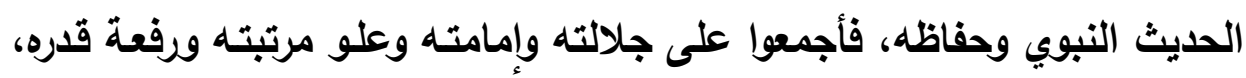

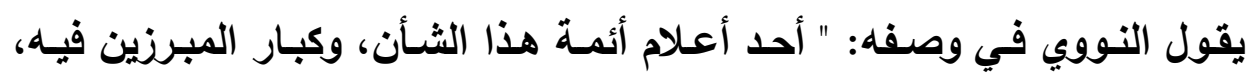

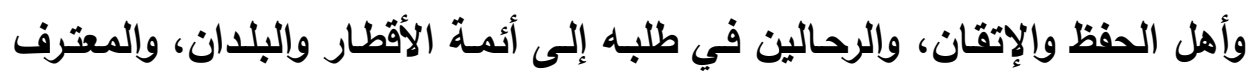

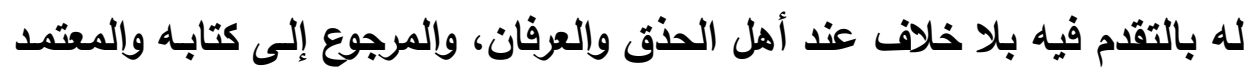

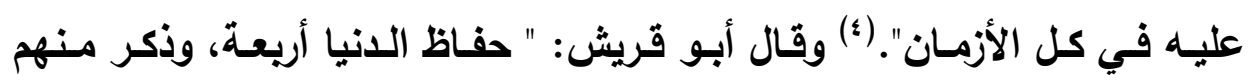
مُسنلمًَا (م).

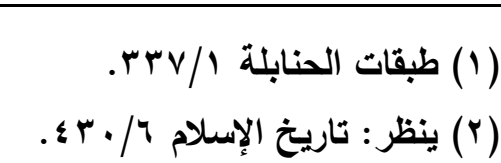

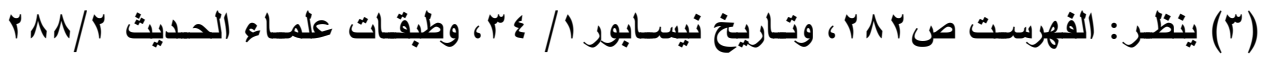

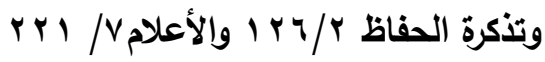

( ) شرح النووي على صحيح مسلم 1/ / / 1.

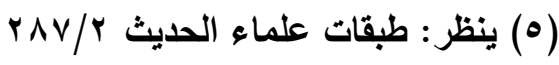


وقال ابن حجر: " حصل لمسلم في كتابه حظ عظيم مفرط لم يحصل لأحد

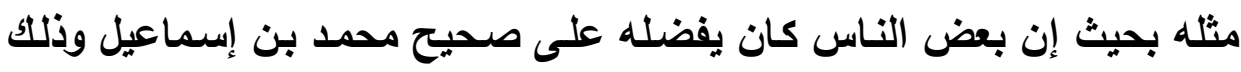

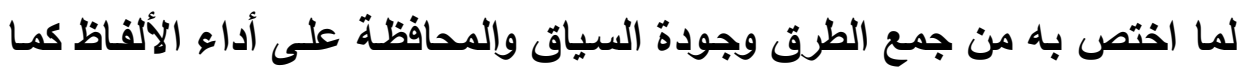

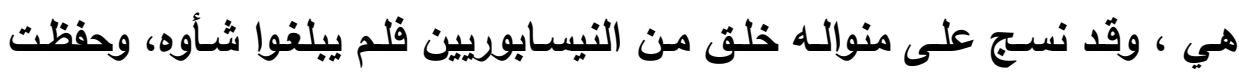
منهم أكثر من عثرين إماما ممن صنف المستخرج على مسلم فسبحان المعطي

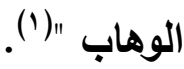

عه وفاته: توفى الإمام مسلم - رحمه الله - يوم الاثثين لخمس بقين من رجب سنة إحدى وستتين ومائتين وهو ابن خمس وخمسين سنة، ومقبرته في

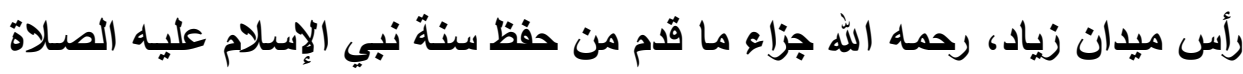

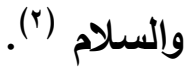

\section{ب - التعريف بصميح الإمام مسلم}

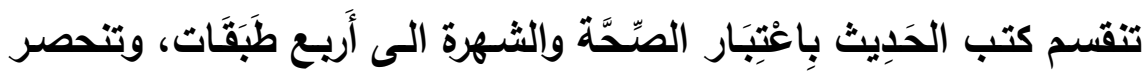

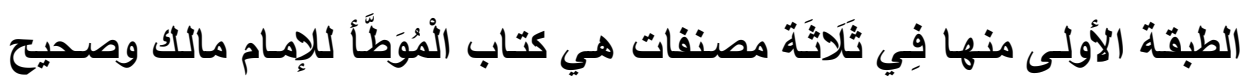

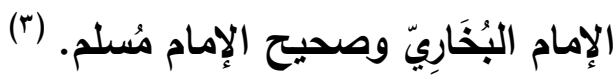
ويعد كتـاب الجـامع الصحيح للإمـام مسـلم بـن الحجـاج أحـا الصحيحين

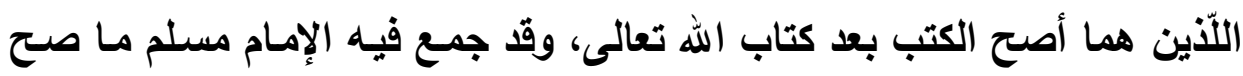
عنده من أحاديث رسول الله صلى عليه وسلم التي بلغت بالمكررات سبعة آلاف تهاب

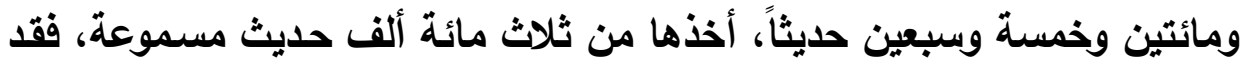

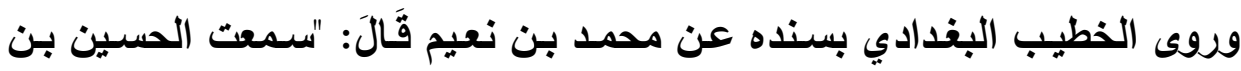

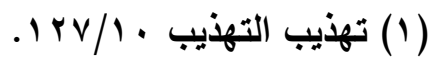

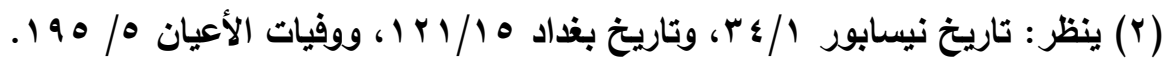

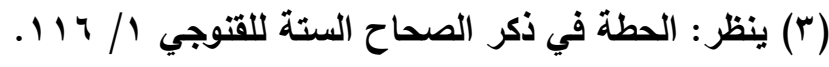


محمد الماسرجسي يقول: سمعت أبي يقول: سمعت مسلم بن الحجـاج يقول:

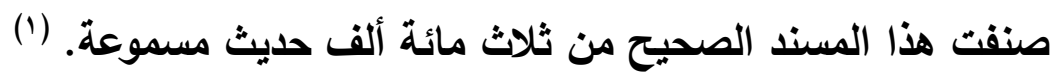

وقد امتـاز كتـاب الجـامع الصـيح لمسـلم بعدة ميزات أثـار إليها ابـن

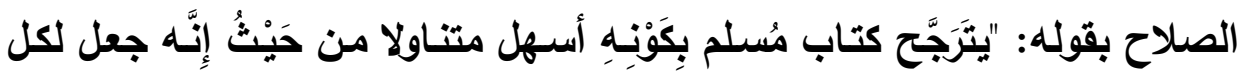

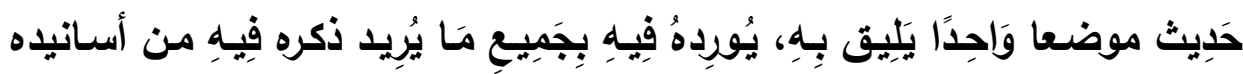

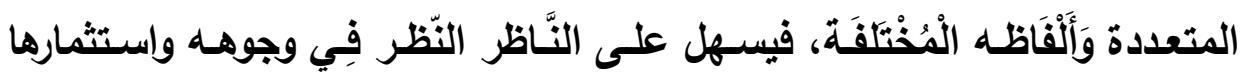

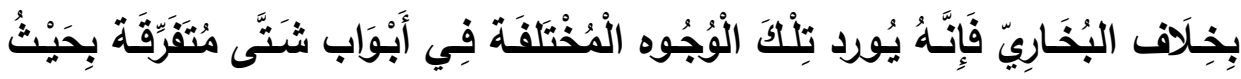

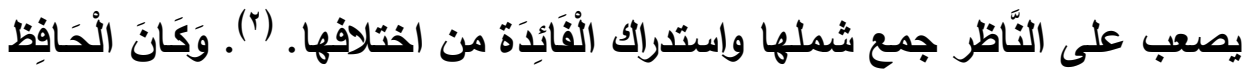

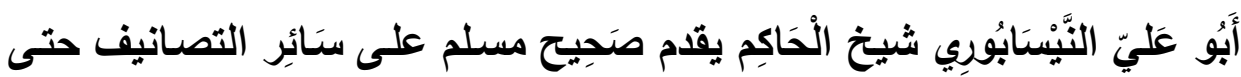

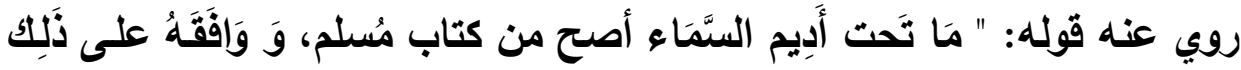

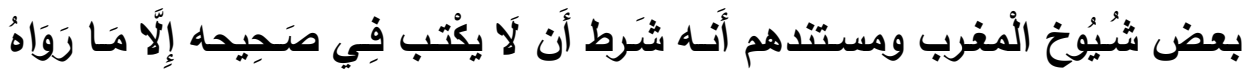

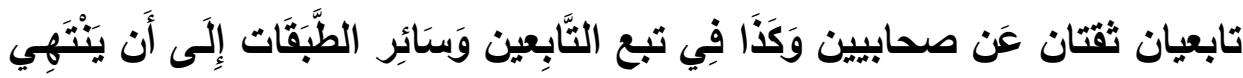

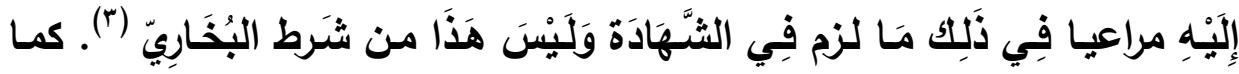

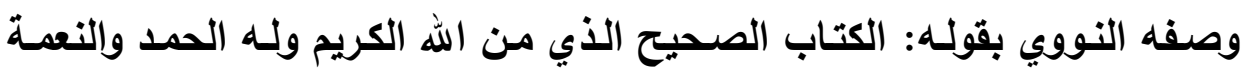

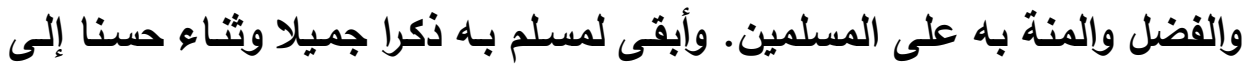

يوم الدين "(ई)

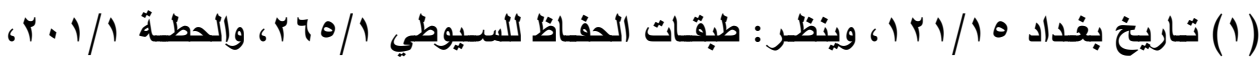

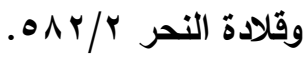

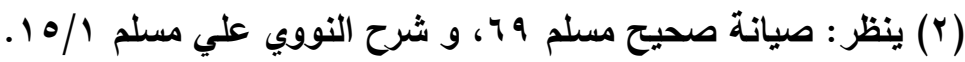

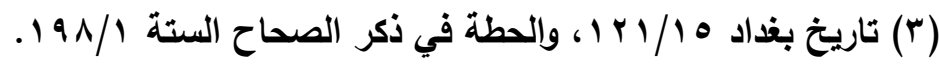

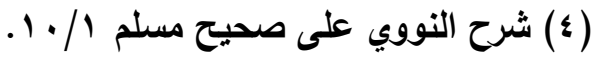




\section{ثانيا: أبو العلاءابن ماهان ودوايته لاصمية

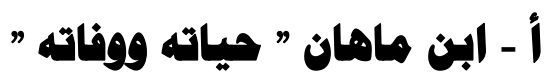

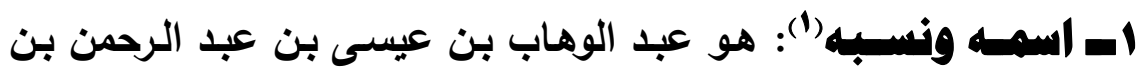

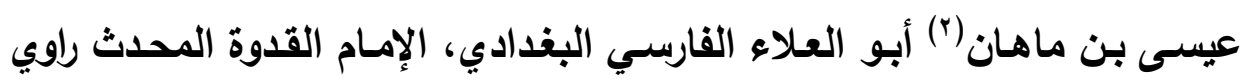

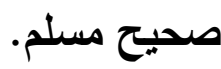

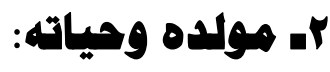

لم تورد المصادر تحديدًا لسنة ميلاد أبى العلاء، أو شيئا عن نشأته

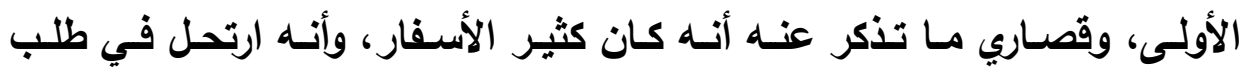

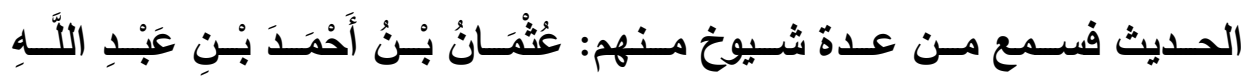

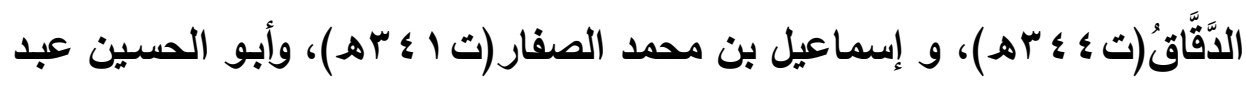

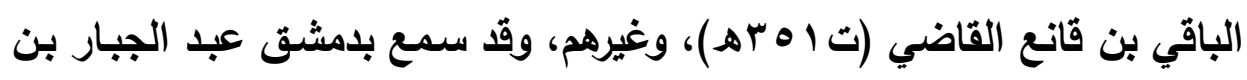

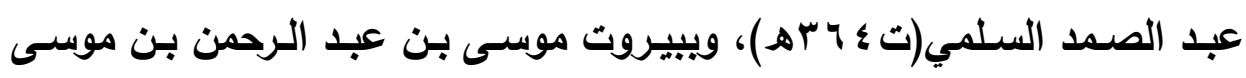

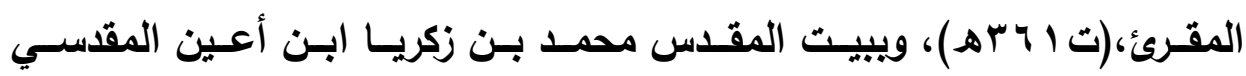

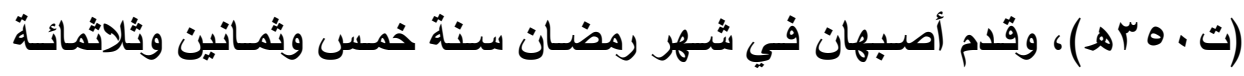

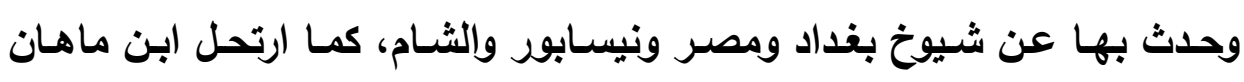

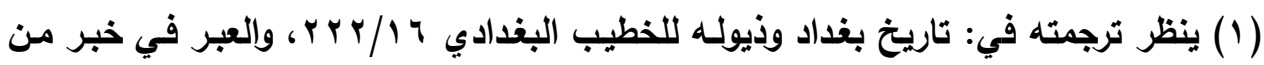

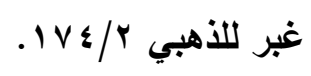

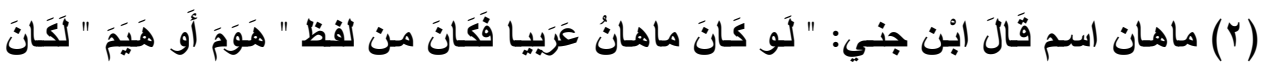

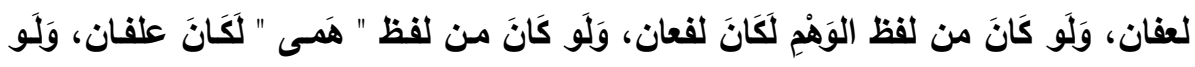

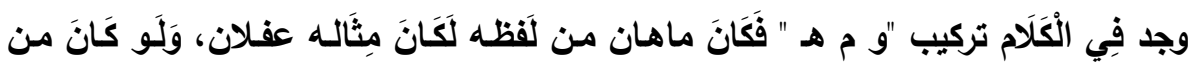

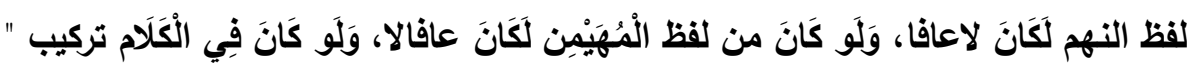

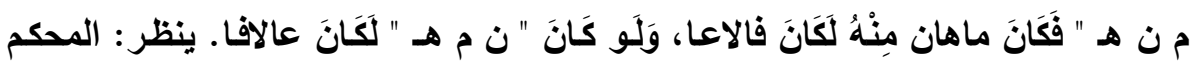

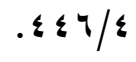




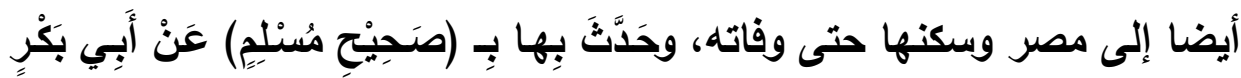

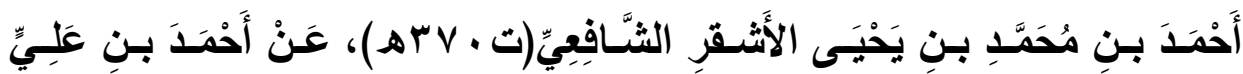

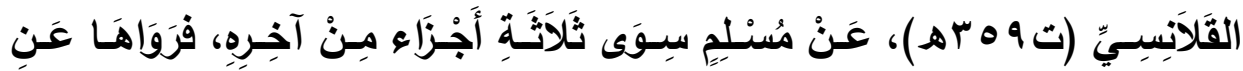

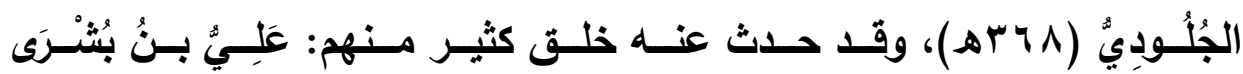

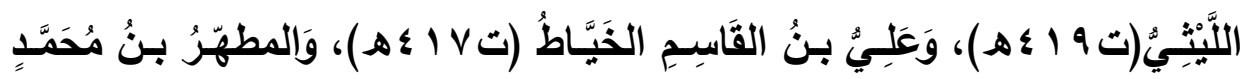

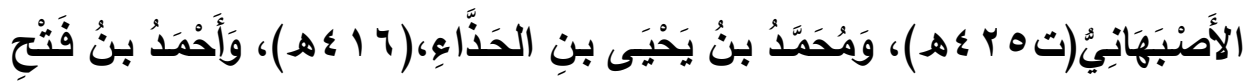

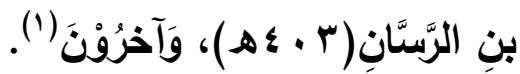

\section{r - مكانته وأقوال العلماء فيه}

كان رحمـه الله من المحدثين الثقات، وممـا يثـهـ بفضله مـا كتبه أبو

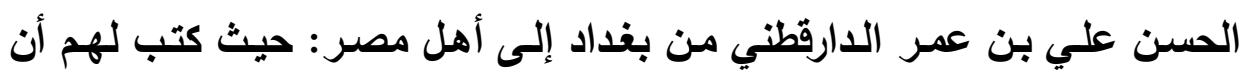

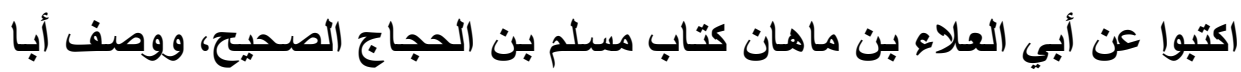

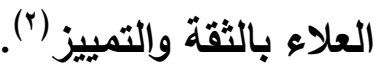

ع - وفاته: وقد توفى ـ رحمه الله_ سنة سبع وثمانين وثلاثمائة(").

\section{ب - رواية ابن ماهان المصيح مسلم}

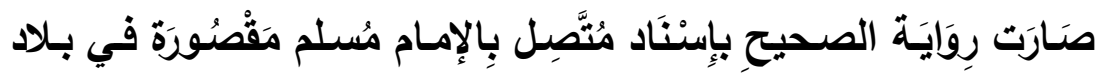

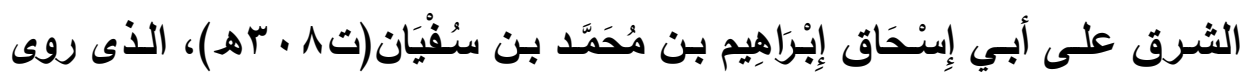

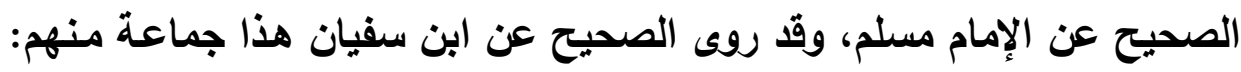

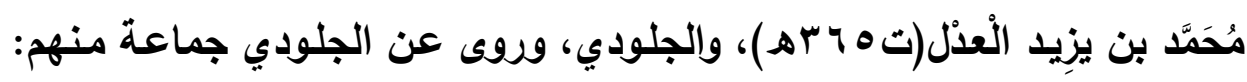

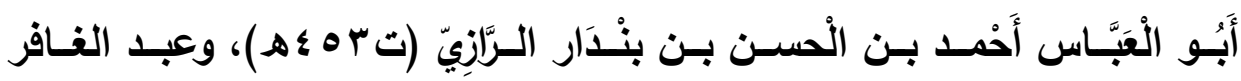

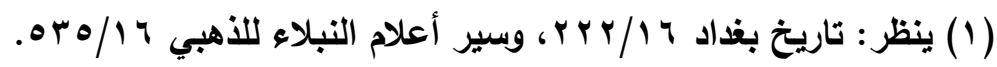

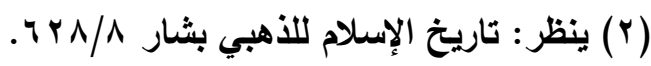

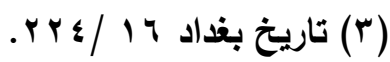




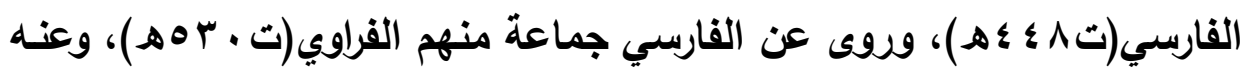

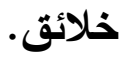

أما في بلاد المغرب فقد وقع عندهم بروايـة أبى مُحَمَّد أَحْمد بن عَلِيّ بن

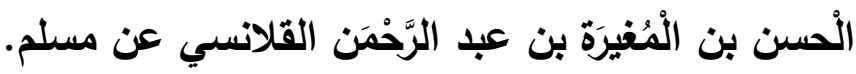

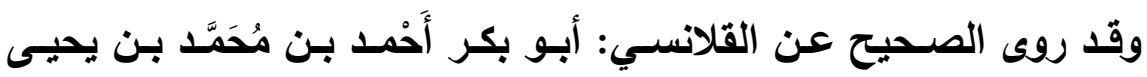
الَْثَتَفَرَ الفقيه، وروي عن الأثشقر أبو العلاء بن ماهان.

وممـا يجدر ذكره أن أبـا العلاء روي الصحيح بهذا الطريق حاشـا ثلاثنة

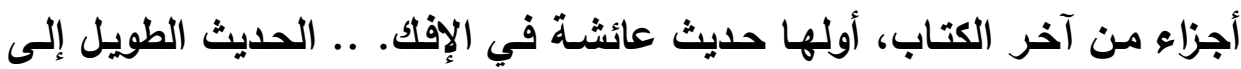
آخر الديوان، فإن أبا العلاء ابن ماهان يروي ذلك عن أبي الجلودي، عن إبراهيم بن محمد بن سفيان عن مسلم بن الحجاج.

وقد دخلت رواية ابن ماهـان الى المغرب عن طريق ابن الحذاء القرطبي الذي كانت له رحلة إلى المشرق كتب خلالها صحيح مسلم من كتاب أبي العلاء

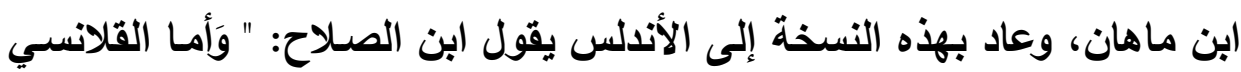

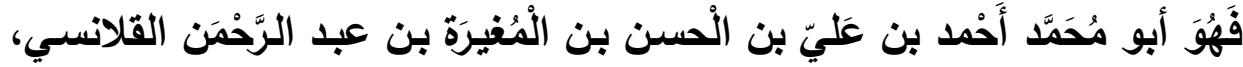

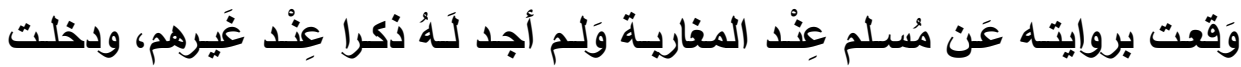

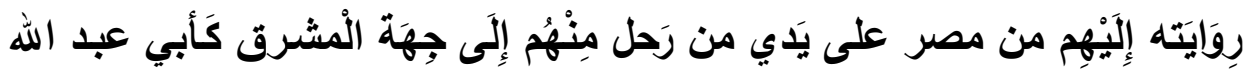

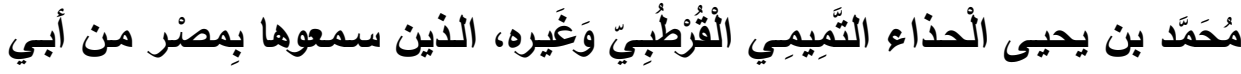

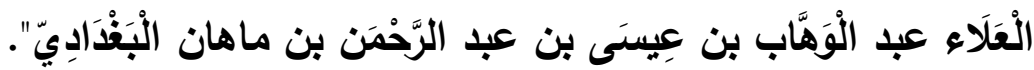
وتعد روايـة ابن ماهان لصحيح مسلم عند المغارية هي الرواية المعتمدة والأكثر أهمية عندهم لكونها لخلت إليهم في وقت مبكر قبل رواية ابن سفيان

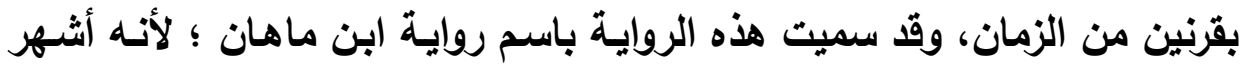

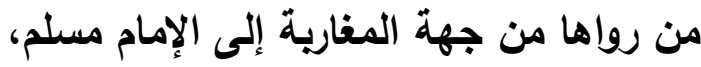


وإليها الإثـارة عند علماء المغرب في اختلاف الرواية، (') كما تعد أيضا

أحد الروايات التي اعتمدها المازري في كتابه المعلم(†).

المبمث الأول: المستوي الصوتي

مما لاثـك فيه ان الاراسـة الصوتية من المقدمات الأوليـة لاراسـة اللغنة،

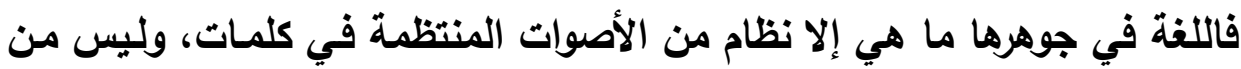

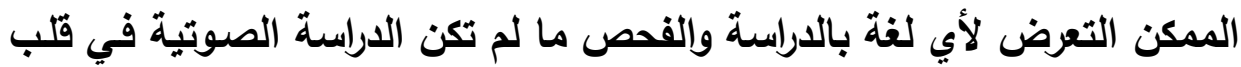

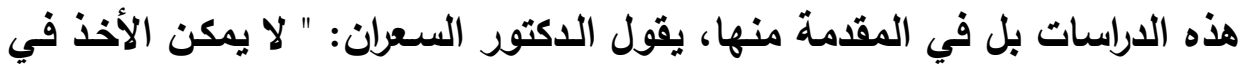

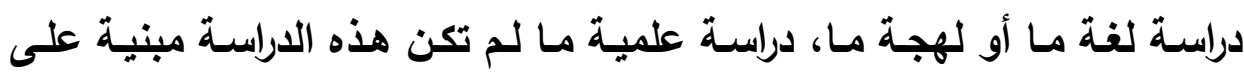

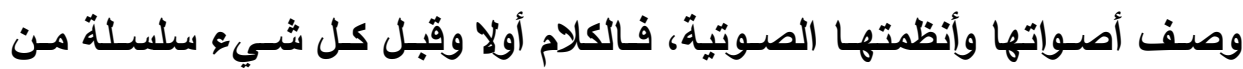

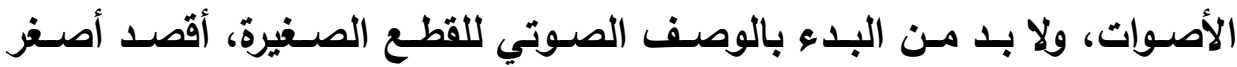

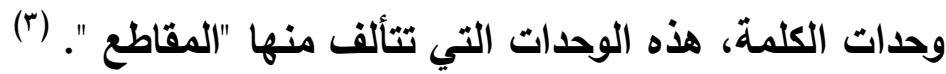
وقــ تضــت روايـات ابن ماهـان لأحاديث صـيح الإمسام مسـلم بعض المظاهر المتعلقة بالأصوات اللغوية، ويبان ذلك فيما يأتي:

(1) صيانة صحيح مسلم لابن الصلاح //11 وما بعدها، و ينظر شرح النووي لصحيح مسلم / / 11 وما بعدها

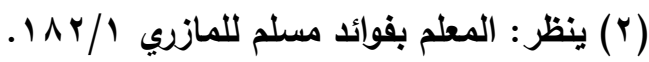

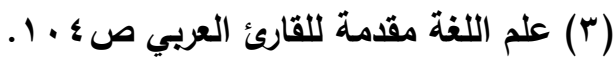




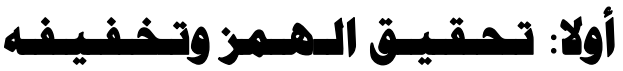

من ظواهر الأداء الصوتي المتعلقة بصوت الهمزة " ظاهرة " تحقيق الهمز وتخفيفه "، فمن المعروف أن الهمزة صوت من أصعب الأصوات نطقًا، وذلك لبعد الادي

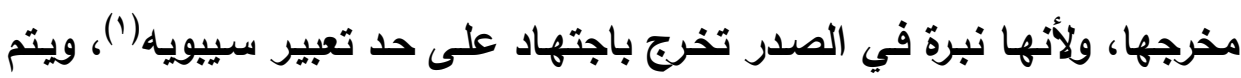
إنتـاج صـوت الهــزة بانطبـاق الـوترين الصسوتيين والغضسروفين الهـرميين في لهي

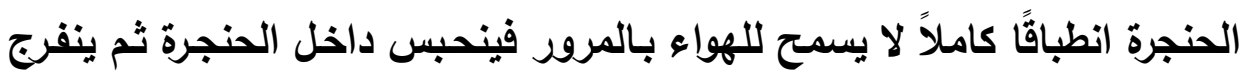

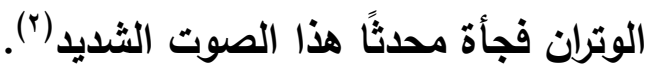

ولا شك أن هذه الوضعية الصوتية أمر عسير يتطلب جها زائدًا مقارنة بغيره من الأصوات، ولهذه الصعوية اتجه بعض العرب في لهجاتهم إلى التخلص

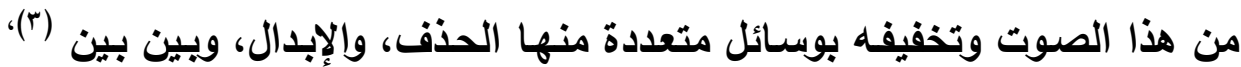

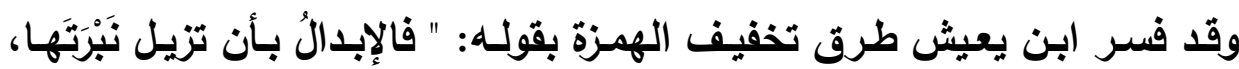

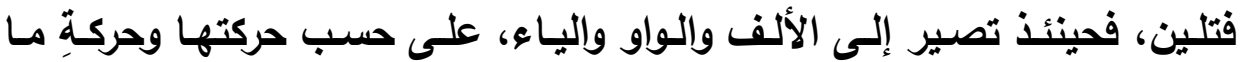

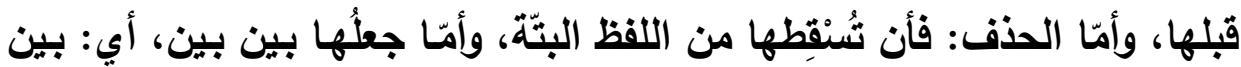
الهمزة والحرف الذي منه حركثُها، فإذا كانت مفتوحة، تجعلها بين الهمزة والألف،

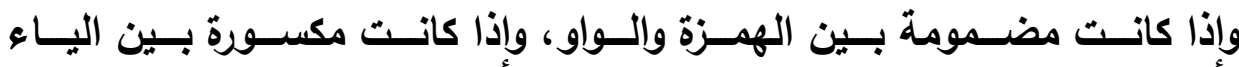

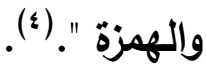

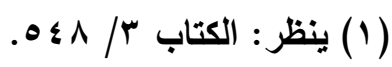

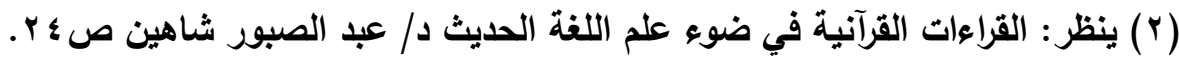

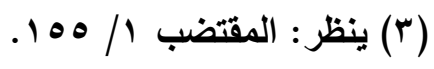

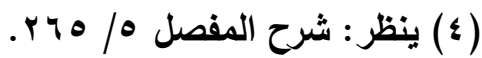


ويغنى بتحقيق الهمز الذى هو مقابل للتسهيل هو النطق بها دون تخفيف

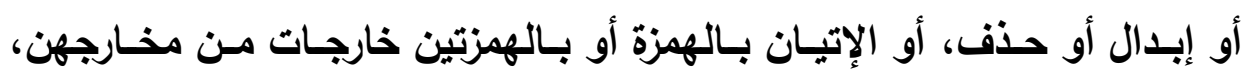

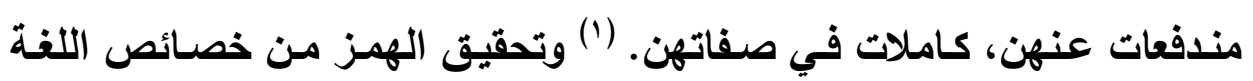

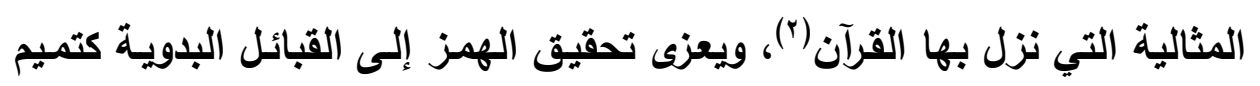

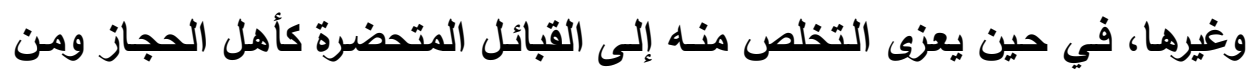
على شاكلتهم (r).

وقا عزى لابن ماهان في روايته لصحيح الإمام مسلم بعض الروايات التي مثلت لغة العرب في صوت الهمزة من جهة التحقيق والتسهيل:

\section{1 - بين تمقيق الهمرة وإبدالها ألفا}

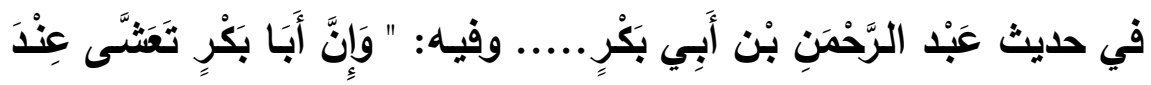

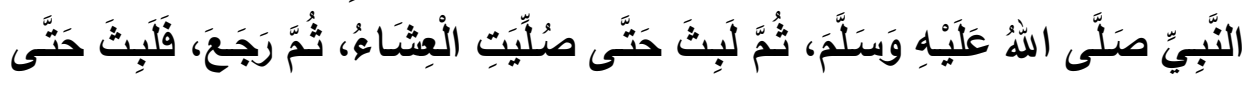

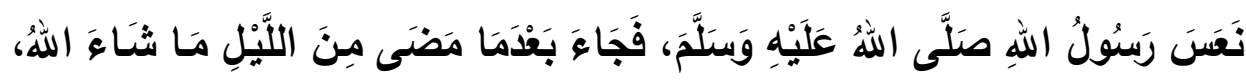

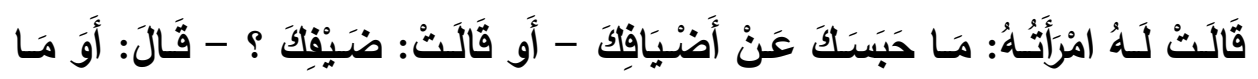

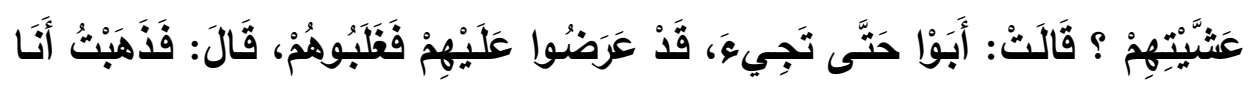

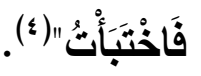

(1) ينظر : التمهيد في علم التجويد لابن الجزي ص لهوه.

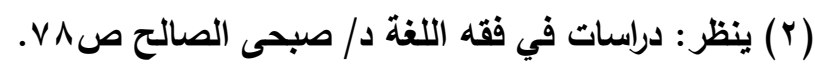

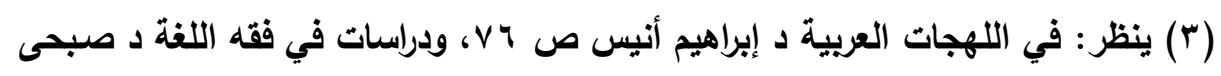

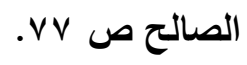

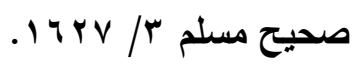




\section{الدراسة والتمليل}

سبياق الحديث في ذكر قصة أضياف من فقراء أهل الصفة، حملهم أبو

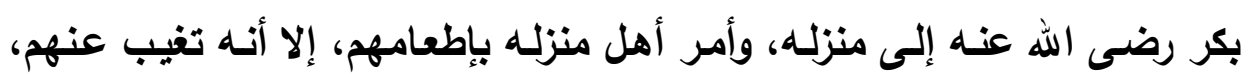

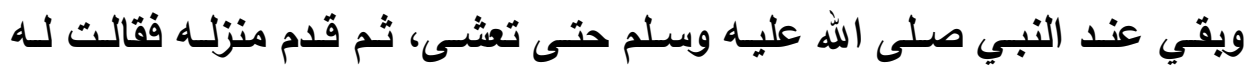

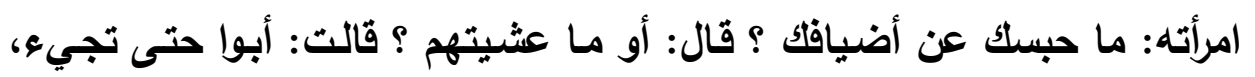

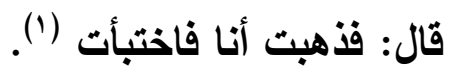

وقوله في الحديث " فذهبت فاختبأت " من كلام عبد الرحمن بن أبى بكر

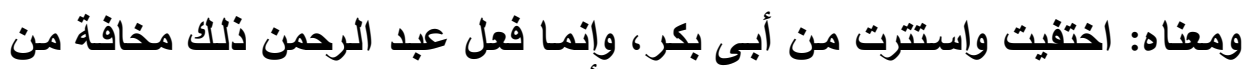
أبيـه ؛ لكونـهـ لـم يطعم الضيفان الذين نزلـوا عندهم، وممـا يقوى ذلكت مـا رواه

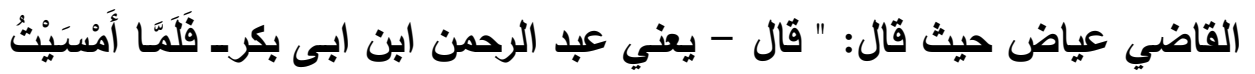

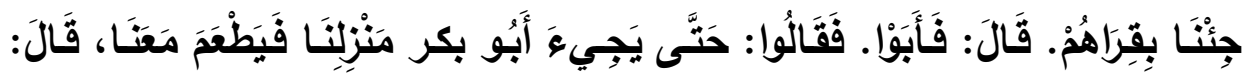

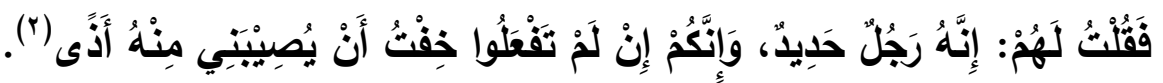
وقد روى قولـه " فاختبأت " بـالهمز ابن ماهـان، ورواه العذري والسـجزي

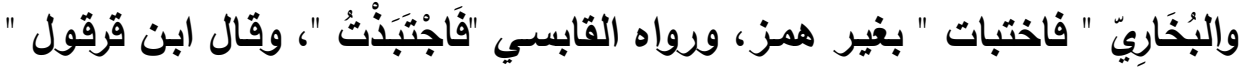

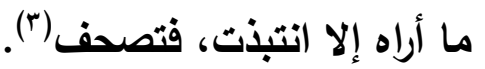
ويبدو الفرق بين رواية ابن ماهان ورواية غيره محصورا فى تحقيق الهمز

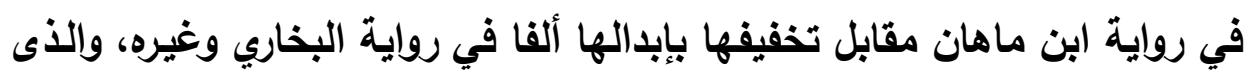

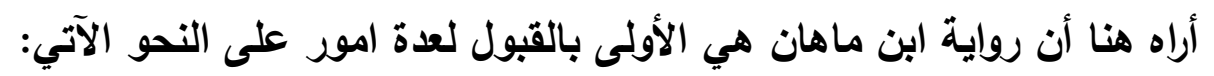

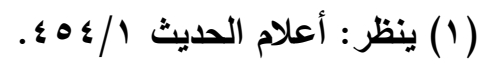

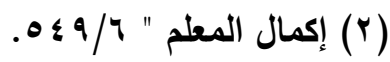

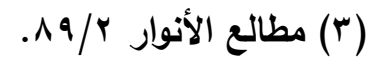


أولا: أنها تتفق مع رواية الأكثرين، ولا يعدو الخلاف بين روايته وروايتهز

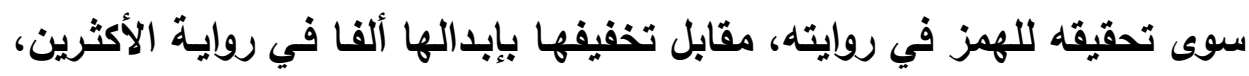

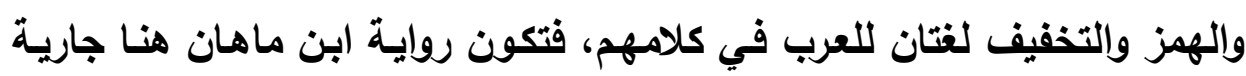
على إحدى هاتين اللغتين وهى التحقيق.

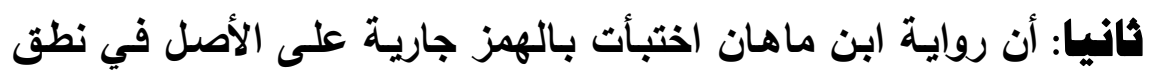

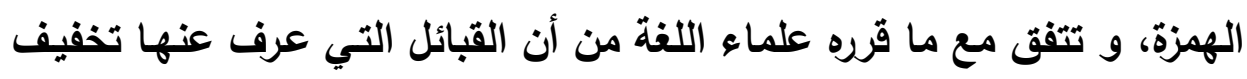

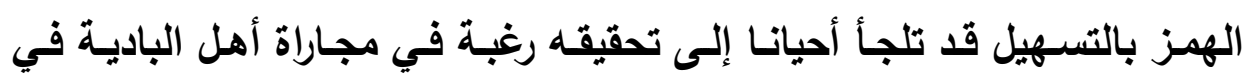

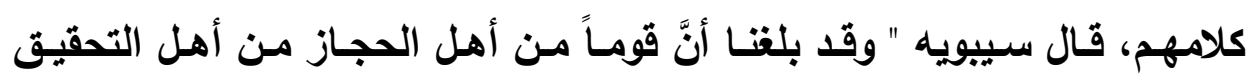

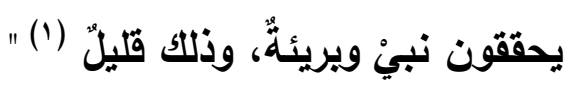

يقول الدكتور صبحى الصـالح: " على أنتـا - بـلا ريب- مـا كنا لنعرف

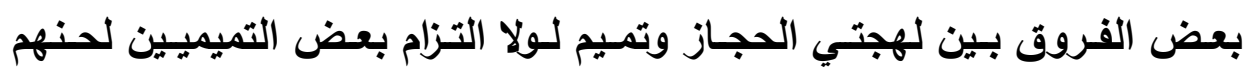

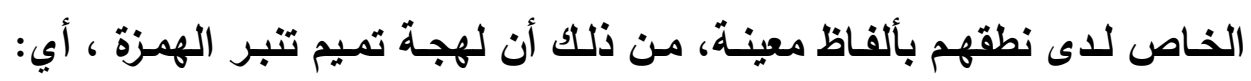

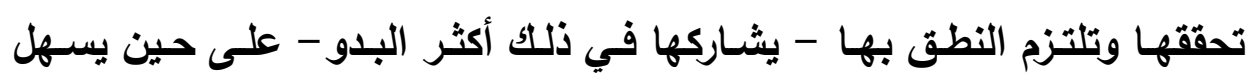

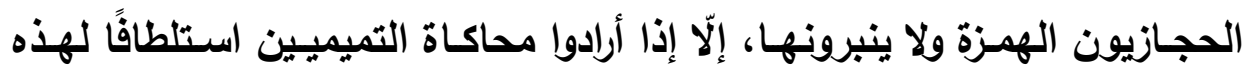

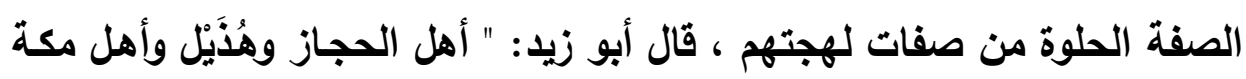

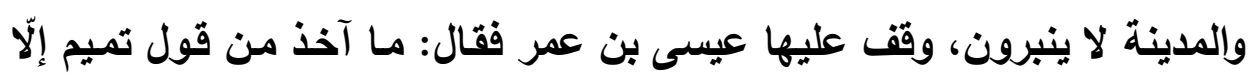

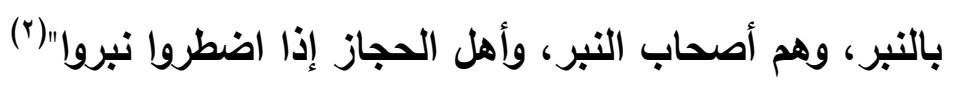
وعلي هذا تكون روايـة ابن ماهـان " اختبأت " بالهمز وردت على لسـان عبد الرحمن بن أبى بكر وهو قرشي يميل إلى التسهيل من هذه المواضع البع القليلة التي يهزهها الحجازيون.

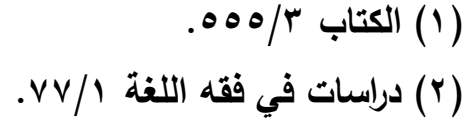


ثالثا: أن رواية ابن ماهان هي الأوفق لمعنى الحديث من جهة الدلالة

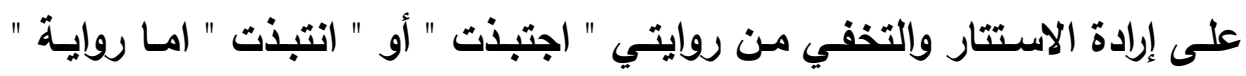
اجتبذت " فاجتبذ مقلوب عن اجتذب بمعنى: شده إليه وحوله عن مكانـه( (1)، وأمسا

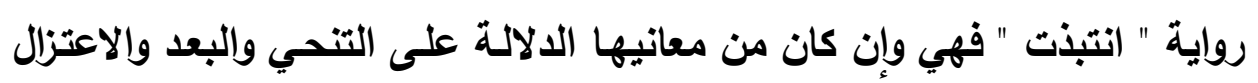

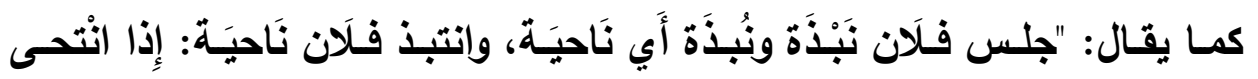

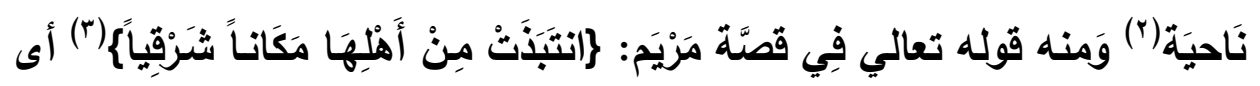

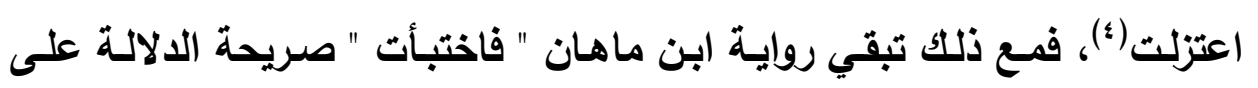

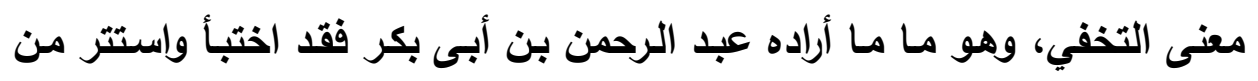

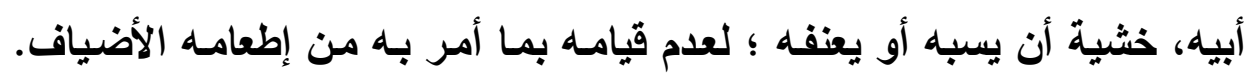

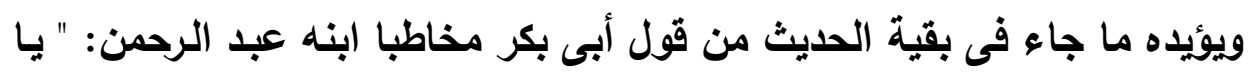

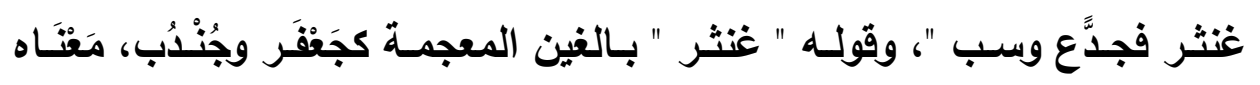

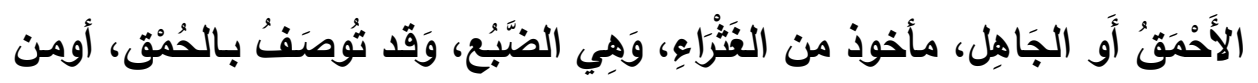

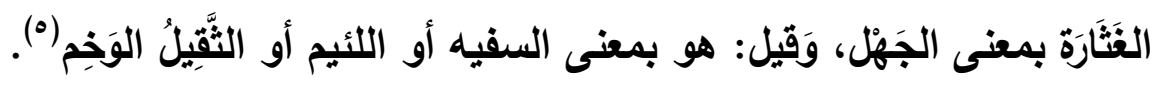

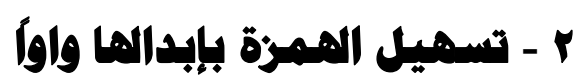

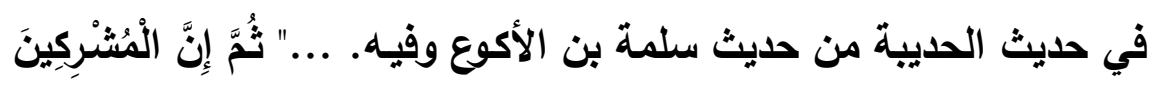

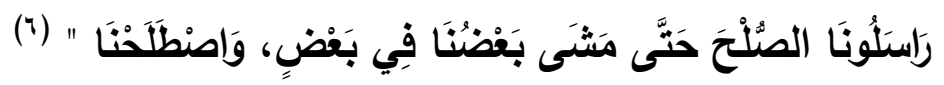

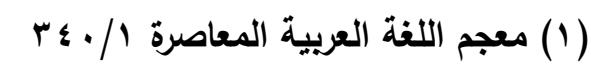

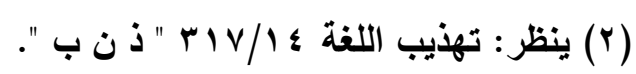

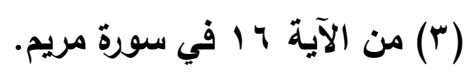

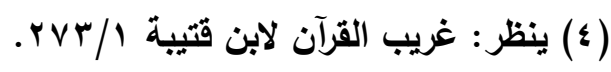

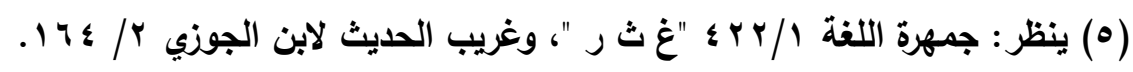

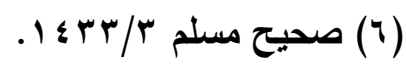




\section{الدراسة والتمليل}

قوله في الحديث " راسلونا " تعددت روايته، فروى في أكثر نستخ مسلم "

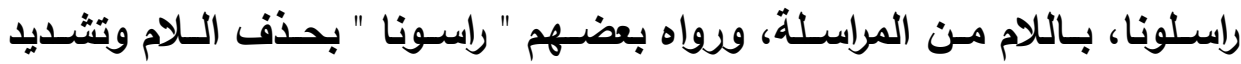

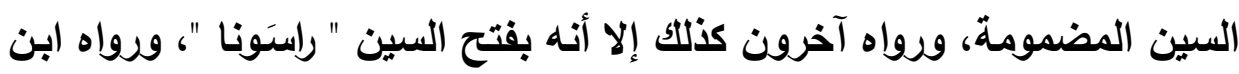

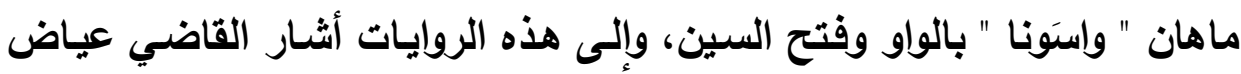

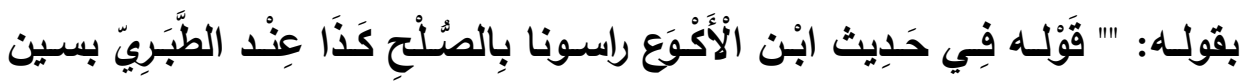

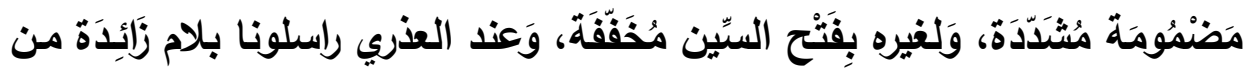

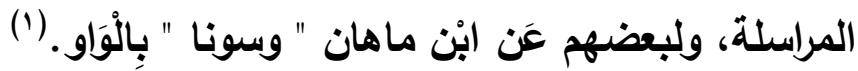

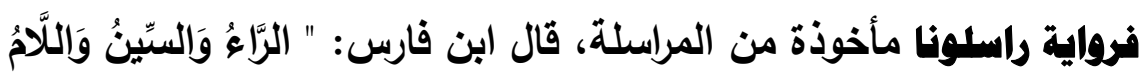

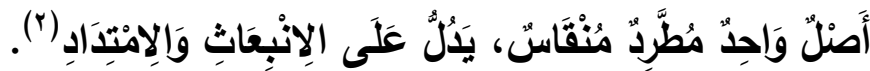

ومعنى هذه الرواية: خاطبونا ويعثوا إلينا بالصلح (ז)

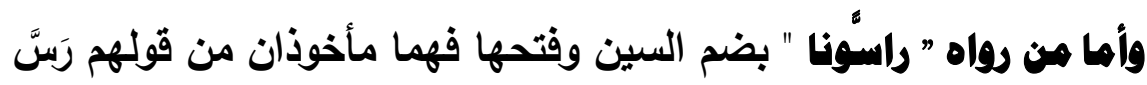

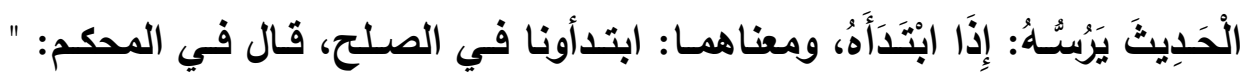

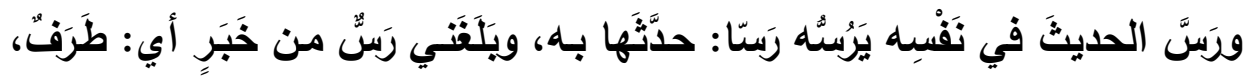

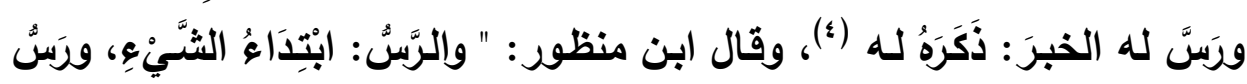

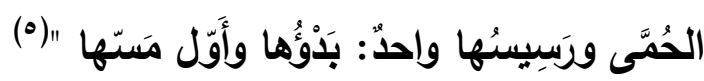

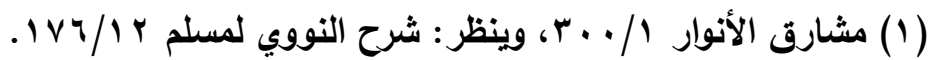

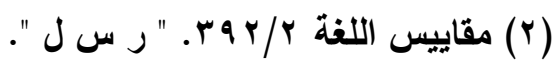

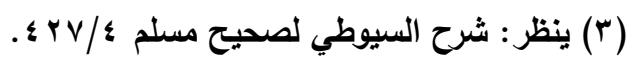

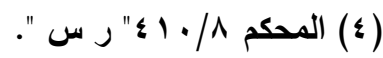

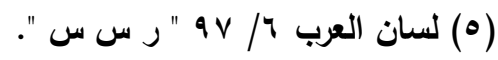


أها رواية ابن ماهان " واسونا " بالواو فقد أنكرها القاضي عياض ذاكرا أنـه

$$
\text { لا وجه لها في الحديث(') }
$$

والذى أراه هنا انه من الممكن قبول رواية ابن ماهان هنا "واسونا " بالواو

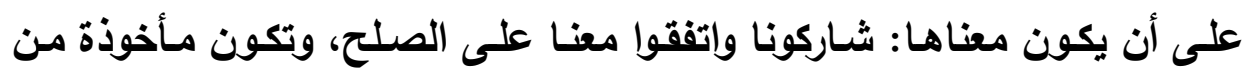

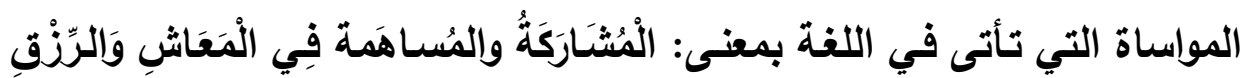
كما في اللسان(ץ) وتكون الواو في هذه الرواية مبدلة من الهمزة وأصلها آسونا. وهذا التخريج لرواية ابن ماهان صرح به ابن الأثير حيث قال: " ويُروى

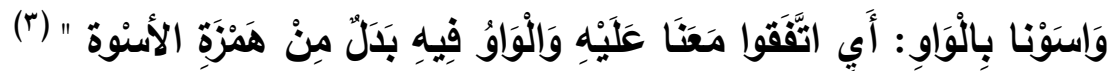
وتخفيف الهمـزة بإبـالها واوًا في آخيت وآسيت جـار على قياسـهم فى تخفيـف الهمـزة المفتوحسة المضـموم مــا قبلهـا بإبــالها واوا، وهـو يعـزى

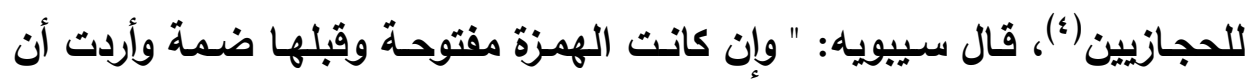
تخفف أبدلت مكانها واواً(*).

وقال الفراء: فأمّا قول العرب: واخيت، ووامرت، وواتيت، وواسيت فإنها

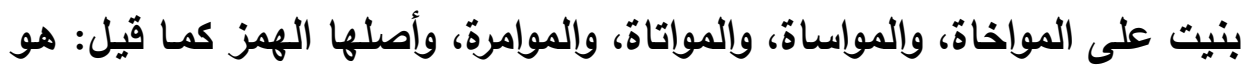

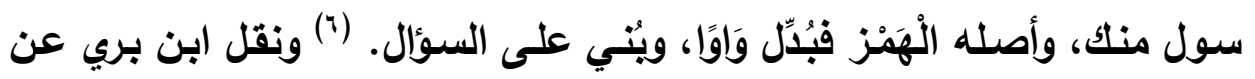

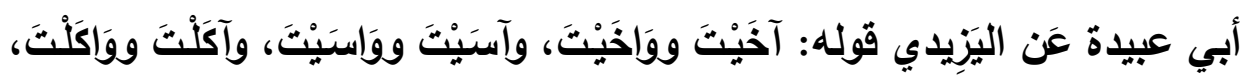

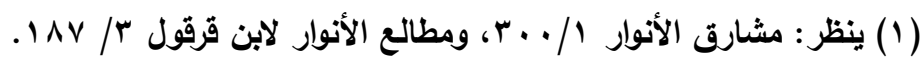

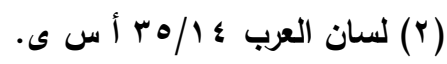

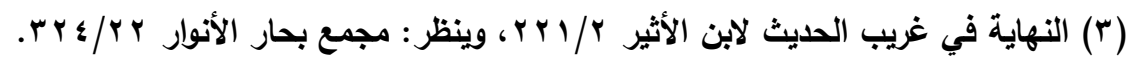

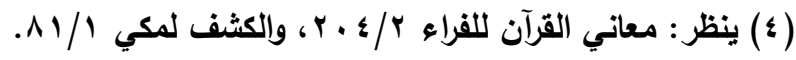

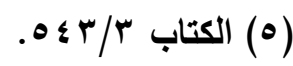

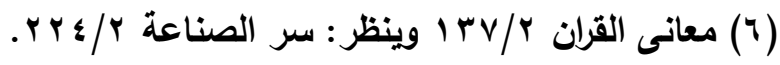




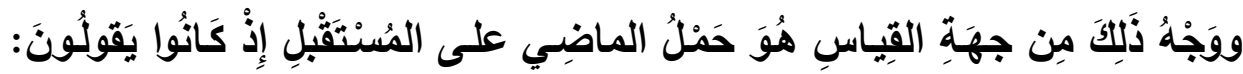

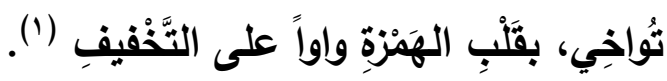

وقد علل الرضي لإبدال الهمزة المفتوحة المضموم مـا قبلها واوا فقال: "

الهمزة المفتوحة إن كـان قبلها ضمة. ..قلبت واوا ؛ لكراهتهم أن تجعل الهمزة

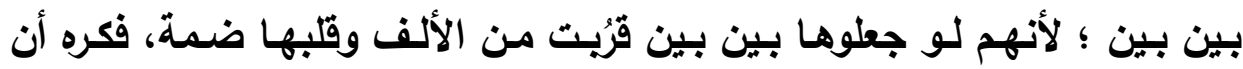

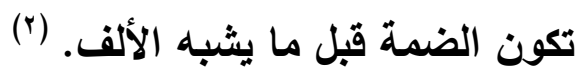

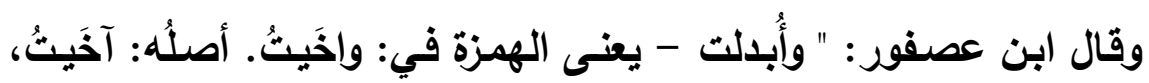

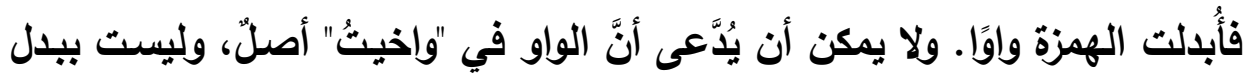

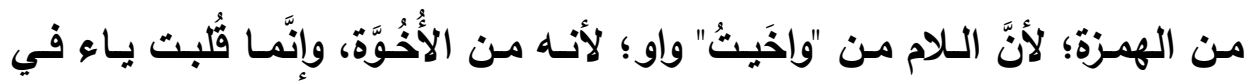

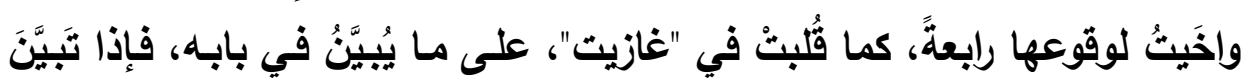

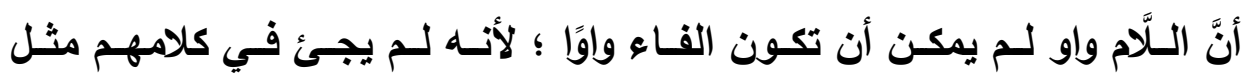

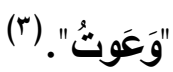

\section{ثانيا: الإدغام}

الأصوات اللغويـة في أي لغة مـا لا توجد منعزلـة ولا يمكن تحليلها على الأى

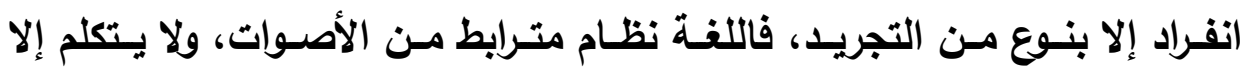

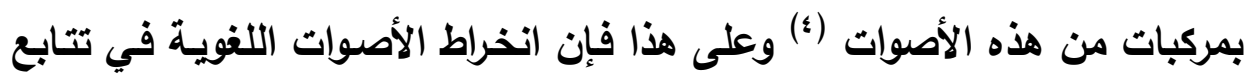

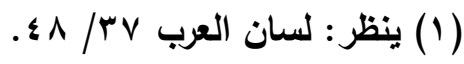

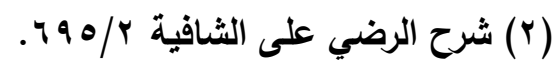

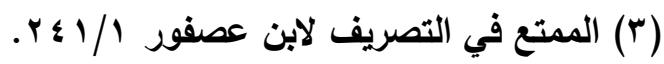

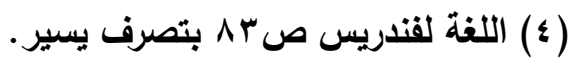


صوتي لإنتاج مركب لغوى ينتج عنه ظواهر أدائية لتلك الأصوات نتيجة لتأثر بعضها بيعض.

ويقرر المحدثون مـن علمـاء الأصسوات أن الأصـوات عندما تتجـاور في السياق الصوتي يتأثر بعضها ببعض نتيجة لذلك، و تختلف الأصوات اللغوية في

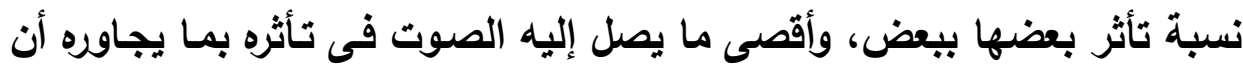

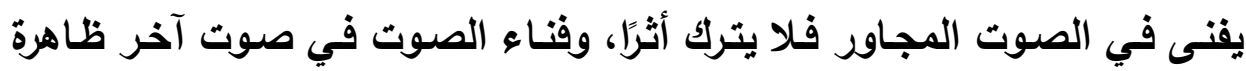

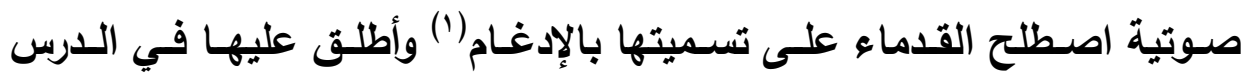

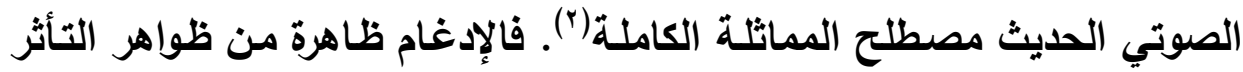

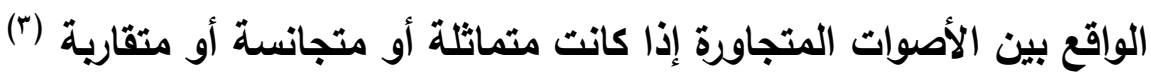
وقد ورد في رواية ابن ماهان لأحاديث صحيح مسلم ما يمكن إدراجه تحت

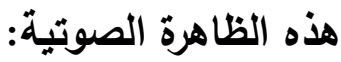

\section{اـ المثلين في " هززت " بين الفك والإدغام}

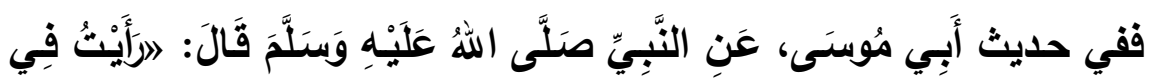

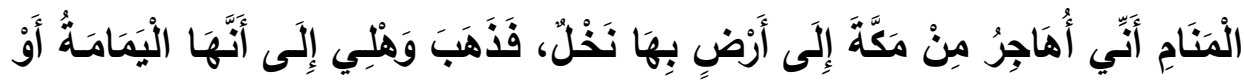

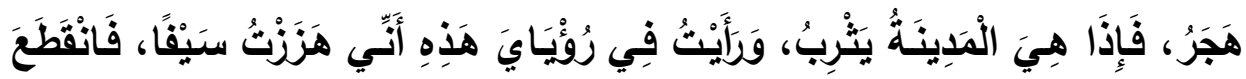

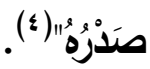

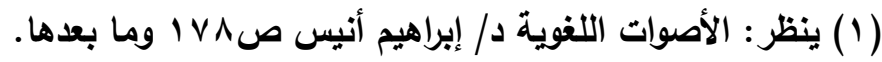

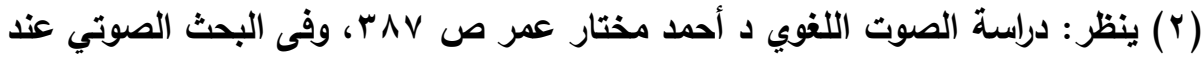

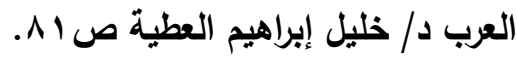

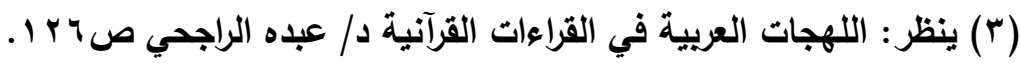

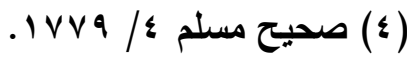




\section{الدراسة والتمليل}

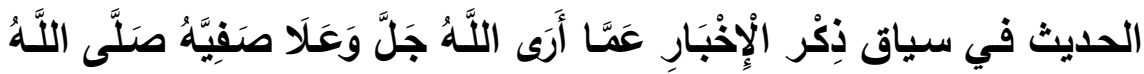

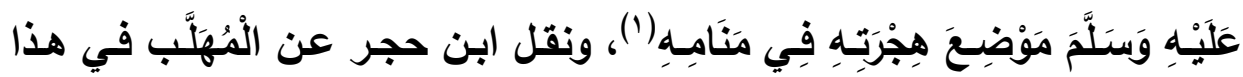

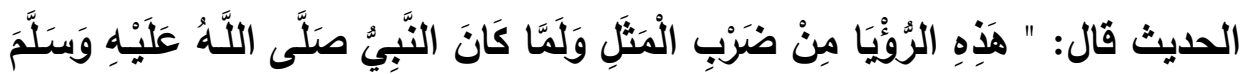

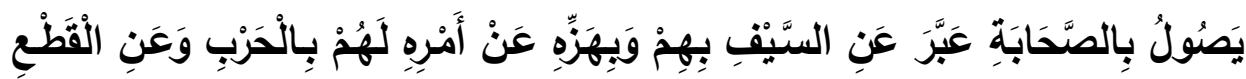

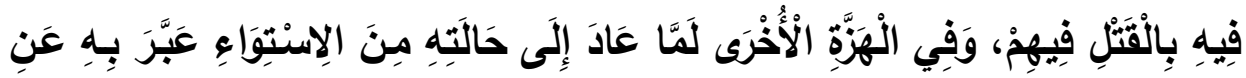

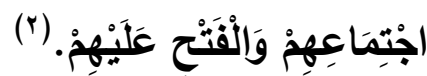

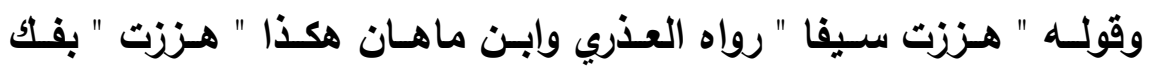
الإدغام في المثلين وهما صوت الزاي، ورواه غيره بالإدغام في الموضعين قال

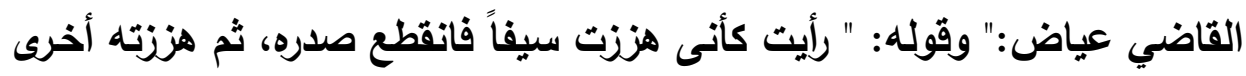

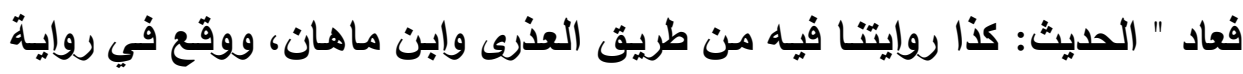

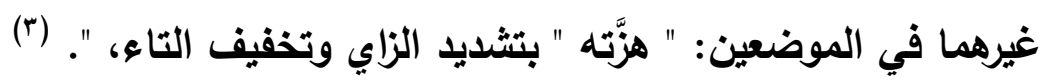

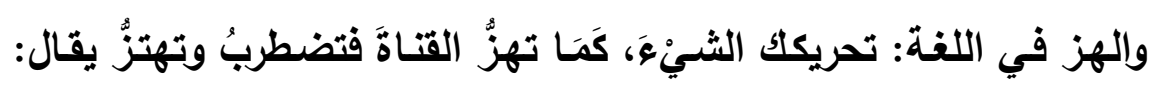

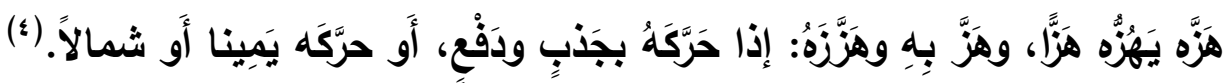
أها رواية ابن ماهـان فهي جاريـة على لغة أكثر العرب عند إسناد الفعل

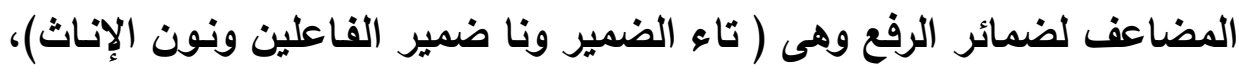

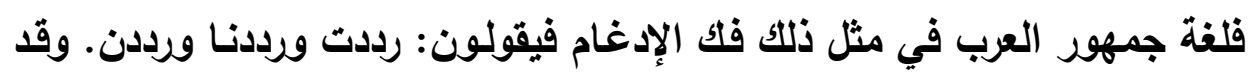

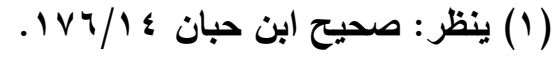

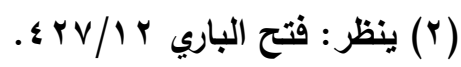

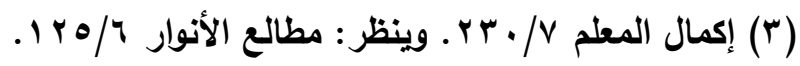

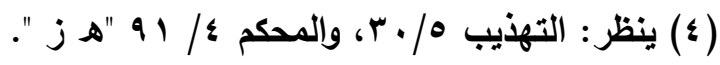


أورد سـيبويه ذلكت في بـاب مضــاعف الفعل واختـلاف العرب فيـه ('): "وفسـره

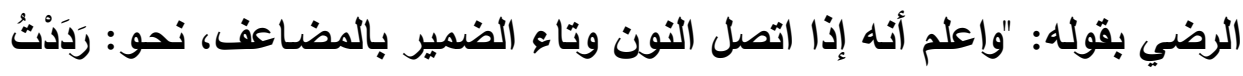

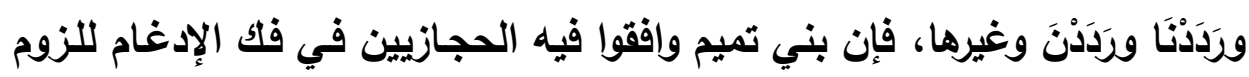

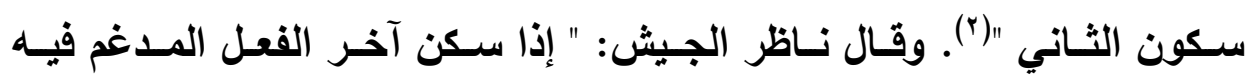

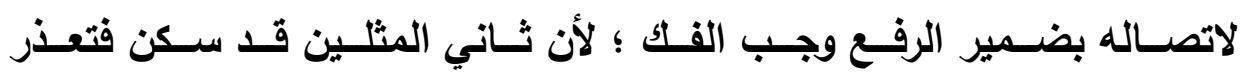

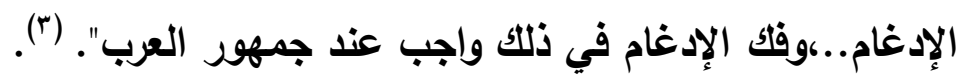

\section{وامها مسن رواه ” هزتـه " فعلى لغة لبعض العرب وهم بنو بكر بن وائل}

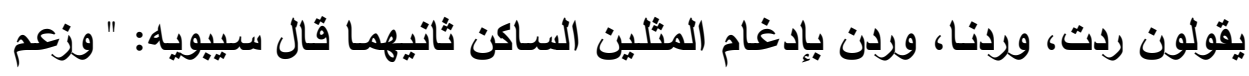

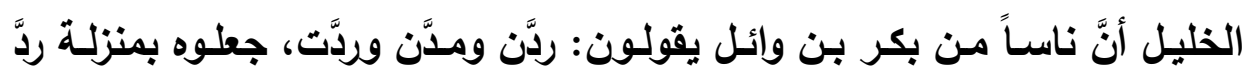

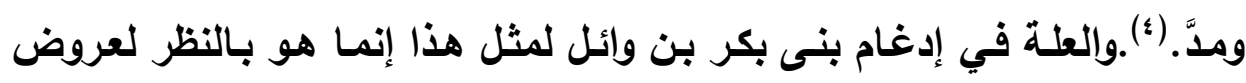

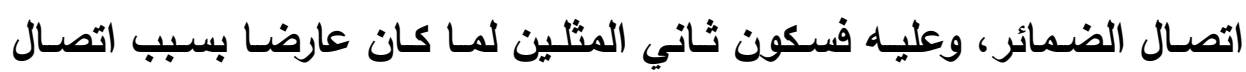

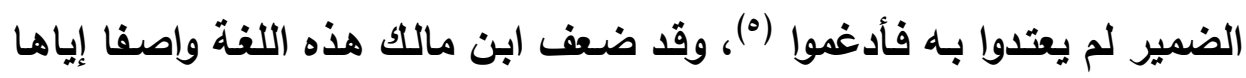

بأنها لغية فقال في التسهيل: والإدغام قبل الضمير لغية (؟).

$$
\begin{aligned}
& \text { (1) ينظر: الكتاب r/ • به. }
\end{aligned}
$$

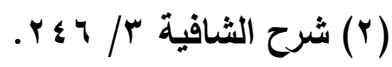

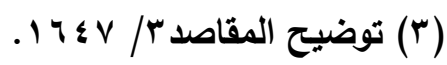

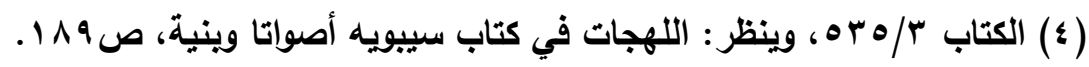

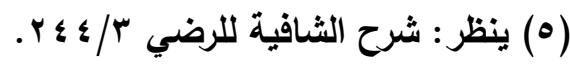

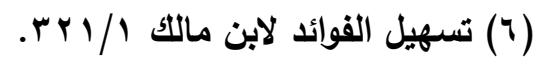




\section{ثالثا: الإبدال بين الصوامت}

يعد الإبدال أهم المظاهر الصوتية المتعلقة بنطق الالفاظ: ويعنى به إقامـة

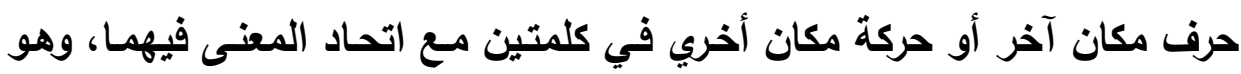

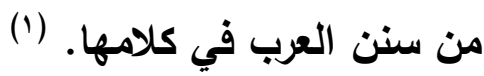

ومرجعه تباين اللهجات العربية في نطق وأداء بعض الألفاظ اللغوية يقول أبو الطيب اللغوي: " ليس المراد بالإبدال أن العرب تتعمد تعويض حرف من في لئ

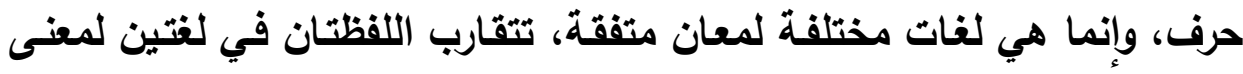

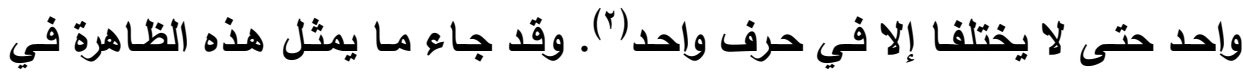
رواية ابن ماهان لصحيح الإمام مسلم وهو التبادل بين صوتي الهمزة والهاء و ذلك فيما يلي:

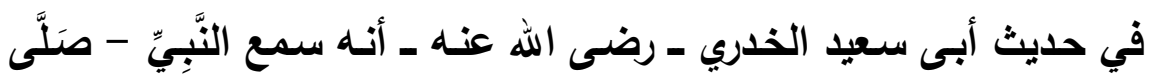

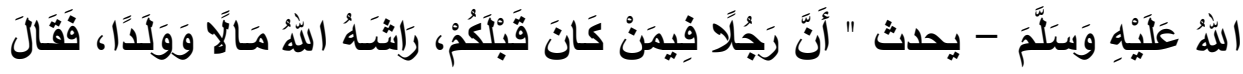

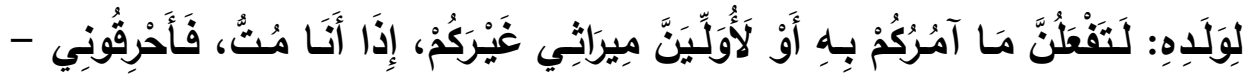

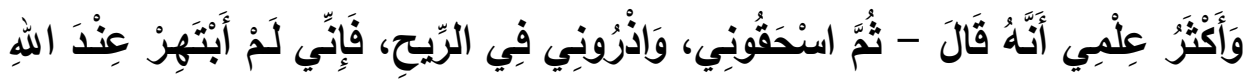
خَيْرًا" (").

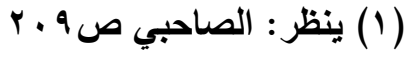

$$
\begin{aligned}
& \text { (r) الإبدال لأبي الطيب اللغوي 19/1. }
\end{aligned}
$$

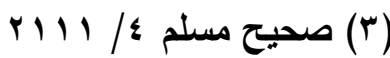




\section{الدراسة والتمليل}

الحديث أخرجها الإمـام مسلم في بـاب سعة رحمة الله تعالي وأنها سبقت غضبه، وسياق الحديث يدور حول قصة رجل وهبه الله مـالا واولادا، فأوصاهم أنـه إذا مـات عليهم أن يحرقوه ويسحقوا عظامـه، ويذروه فى الهواء مخافة من

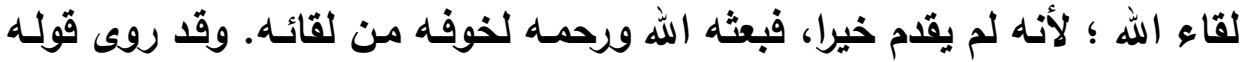
" يبتهر" بالهاء، ورواه ابن ماهان بالهمزة، قال القاضي عياض: " أكثر روايات

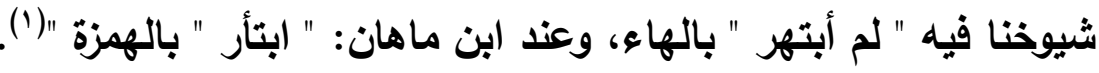
وينحصر الخلاف بين رواية الأكثرين ورواية ابن ماهان في إبدال الهاء في قوله " يبتهز " همزة فيقال " يبتئر ". وحدوث الإبدال بين صوتي الهمزة والهاء واقع في كثير من كلام العرب

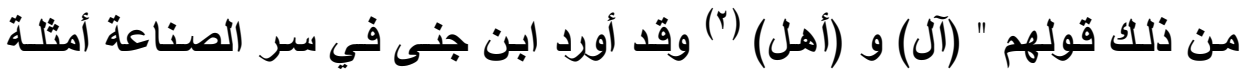

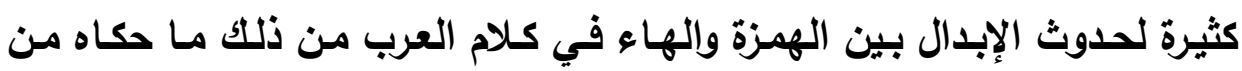

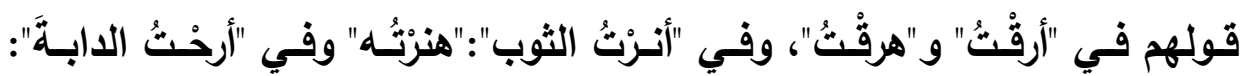

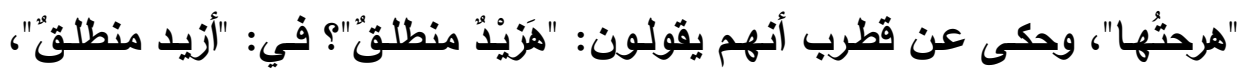

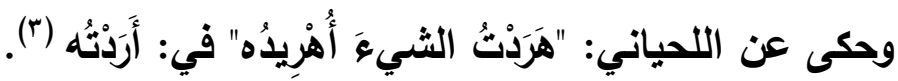
والعلة الصوتية في حدوث هذا التبادل بين صوتي الهمزة والهاء واضحة و

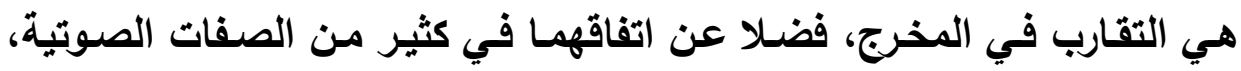
فكلاهما يخرج من الحنجرة فهما صوتان حنجريان والهمزة: صوت شديد مهموس فئس

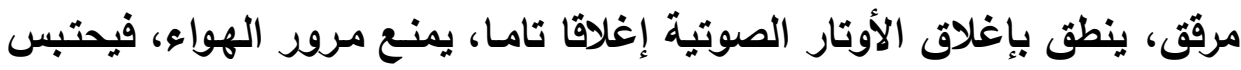

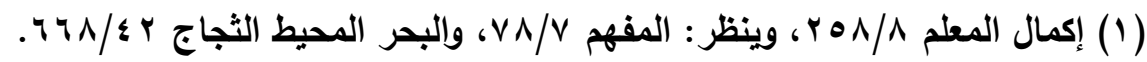

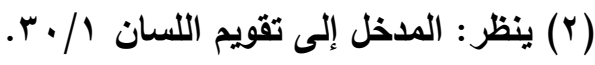

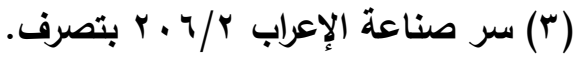


خلفهما ثم تفتح فجأة، فينطلق الهواء متفجرا. ويأتي الحكم بهمس الهمزة، من ناحية أن الأوتار الصوتية معله، تغلت تماما، فلا يحدث فيها ذلك الك الاهتزاز اللازم

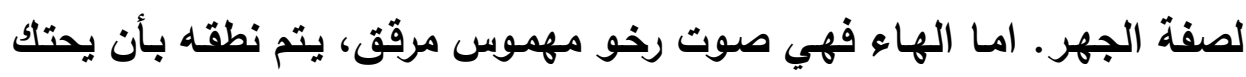

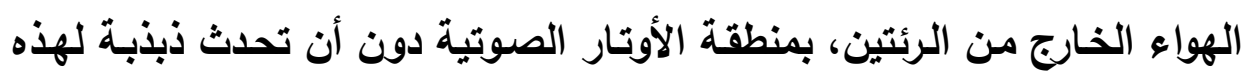

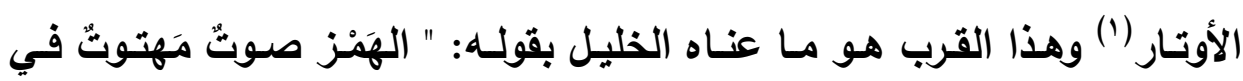

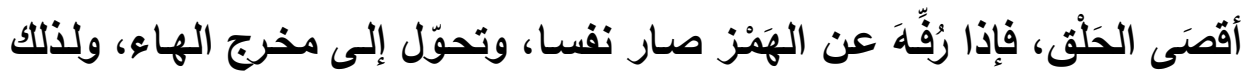

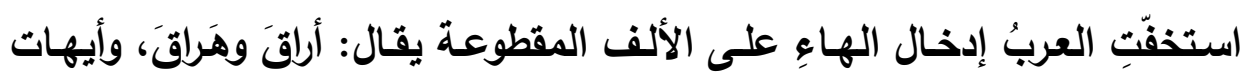

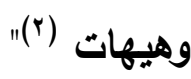

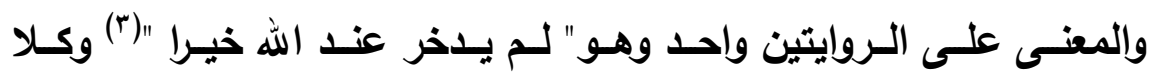

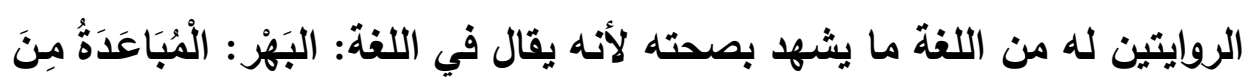

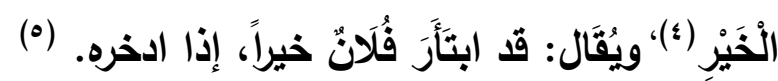

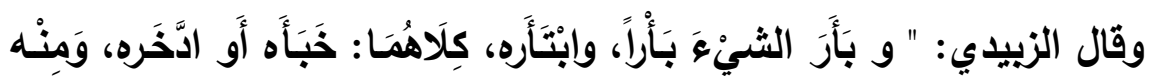

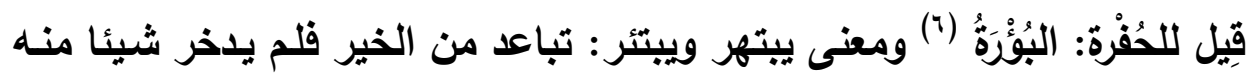
لعاقبته.

وروايـة ابـن ماهـان بـالهمزة هـي الأولـى بـالقبول لـورود الحـديث بطـرق

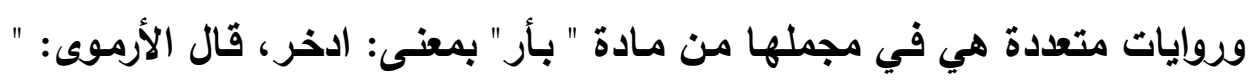

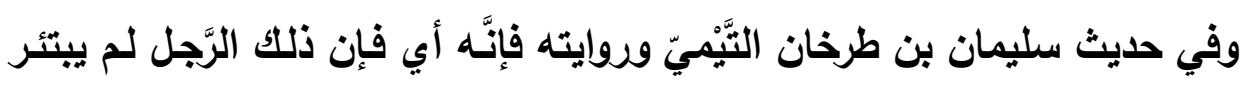

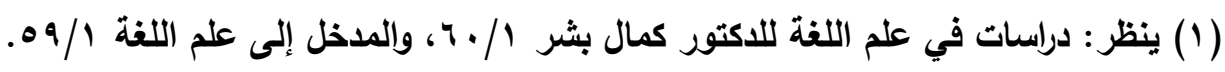

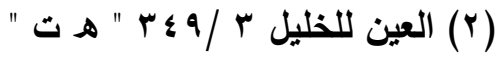

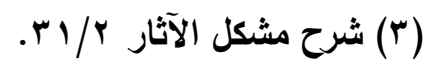

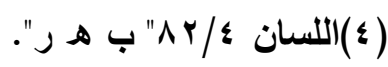

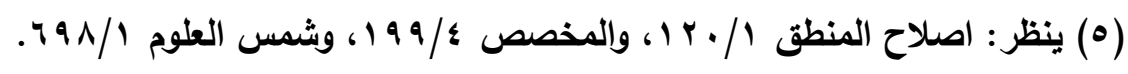

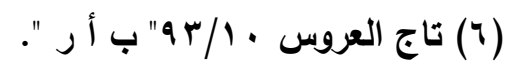


عند الله خيرًا قال سليمان: فسرها أي فسر هذه الكلمة (قتادة) وقال معناها: لـ

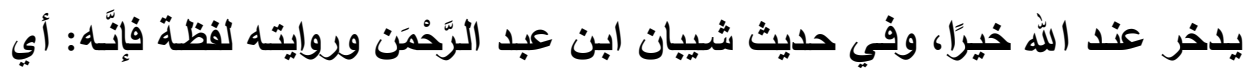

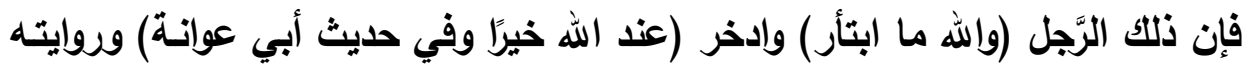

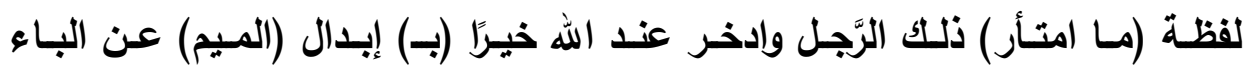

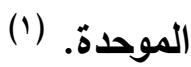

\section{المبمث الثاني: المستوى الصرفي}

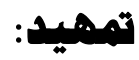

المستوى الصرفي: أحد مستويات الدرس اللغوي الذي يعنى برصد التغيرات

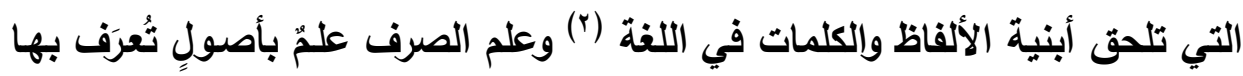

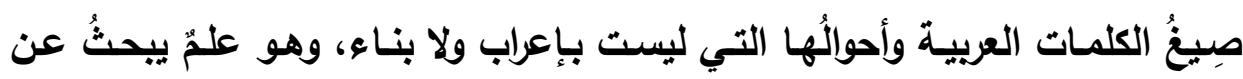

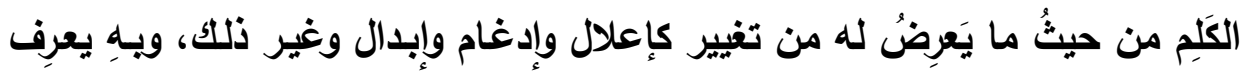

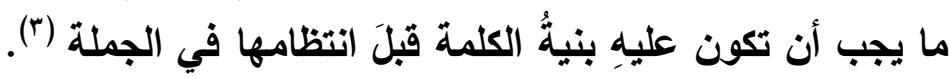
وقد جاء في رواية ابن ماهان لصحيح مسلم عدد من الروايات التي تختلف

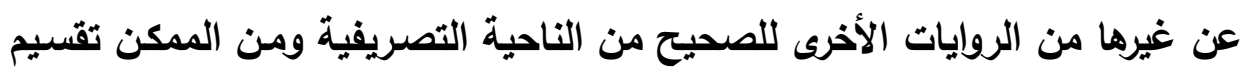

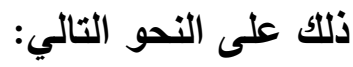

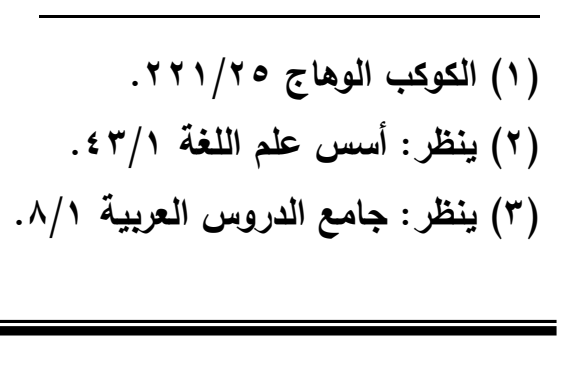




\section{أولا: اختلاف الرواية في صيغ الأسماء}

\section{|- 1 التصغيز}

من الظواهر الصرفية المختصـة بالأسـماء التصغير وهو عبارة عن تغيير الاسم ليال على صغر المسمى وقلة أجزائه، إذ الكبير مـا كثرت أجزاؤه والصغير

بعكس ذلك (1).

ويقع في الكلام على أضرب الأول: التصغير، ويختصّ بالجثث ؛ لأنه ضد

الكبير، نحو: جمل وجميل، الضرب الثاني: التحقير ويختصّ بمـا يظنّ عظيمـا ؛ لأنه ضدّ التعظيم، نحو: ملك ومليك، الضرب الثالث: التقريب، ويختصّ بمـا يظنّ بعيدا نحو: فويق السطح، ودوين السقف، وقبيل الشـهر، الضرب الرابع: التقليل ويختص بالمقـادير نحو: مويـل، ودريهمـات، وحنيطـة، وأجيمـال(؟). وفيمـا بـأتي دراسة لما جاء من روايات ابن ماهان مما يندرج تحت هذه الظاهرة:

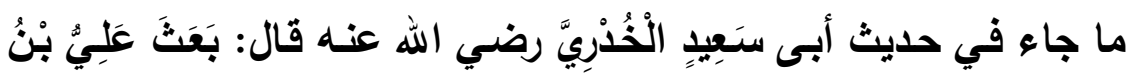

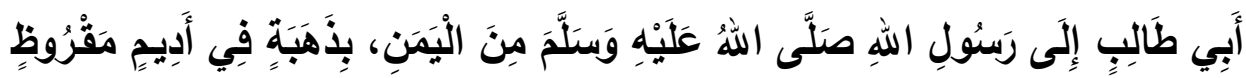

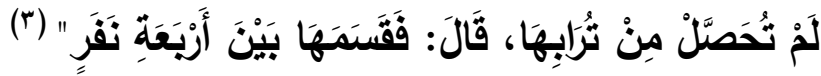

\section{الدراسة والتماليل}

ورد هذا الحديث في باب إعطاء من يخاف على إيمانـه، و قولـه "بذهبة " هكذا رواه كافة الرواة عن مسلم، وجاء في روايـة ابن ماهـان " بذهيبة " على

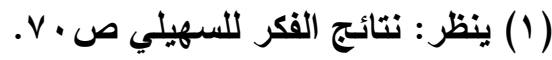

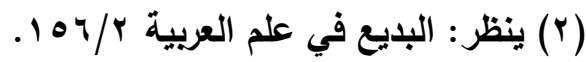

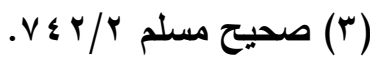




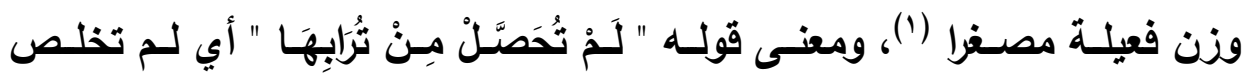
وتصفى.

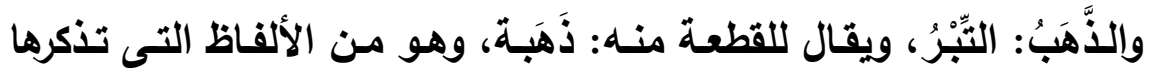

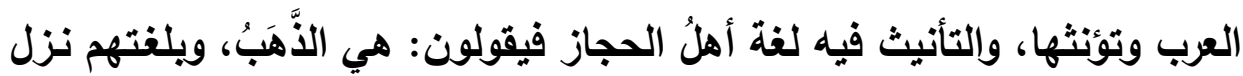

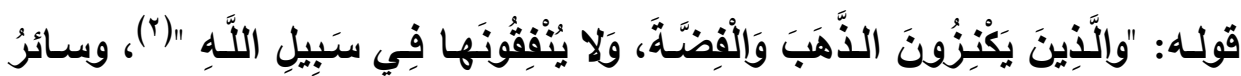

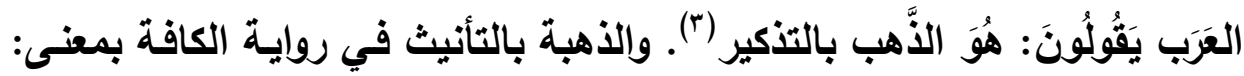
القطعة من الذهب وقد جاهت في رواية ابن ماهان بلفظ " ذهيبة " بالتصغير،

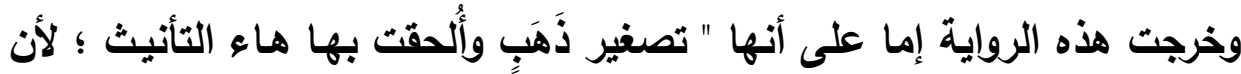

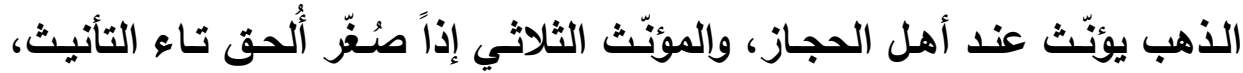

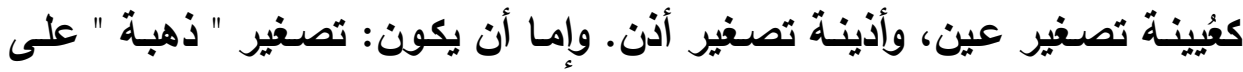

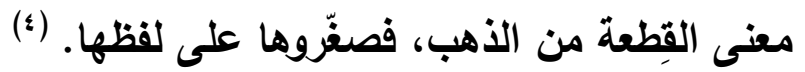

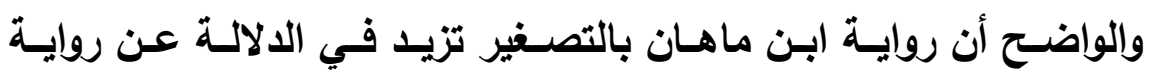

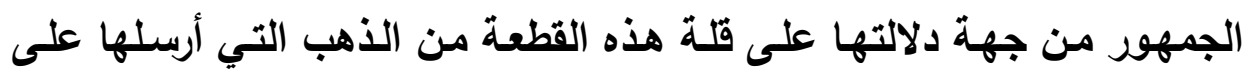

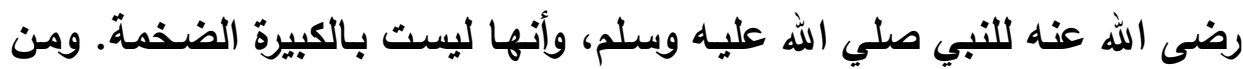
أغراض التصغير التقليل علي نحو ما ذكر الخليل(ه):

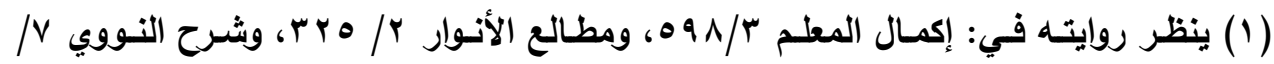
.171

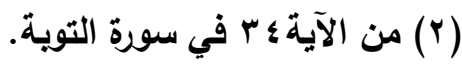

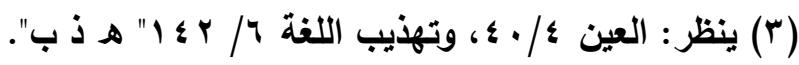

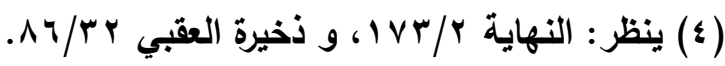

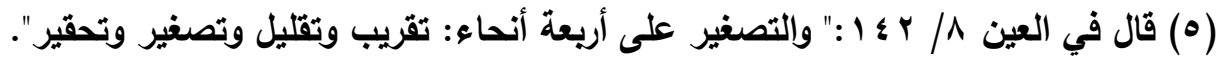




\section{rـ فعل وفعيل " شقص وشقيص "}

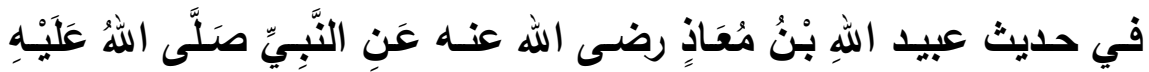

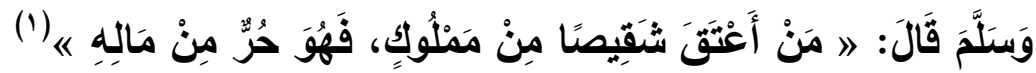

\section{الدراسة والتمليل}

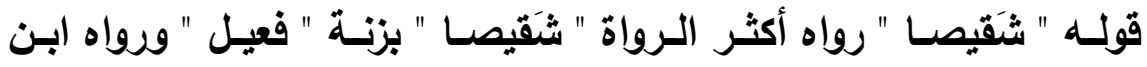

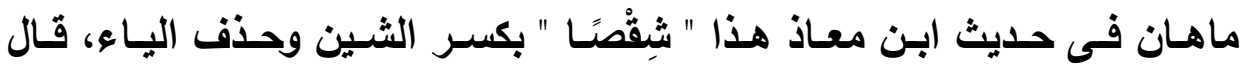

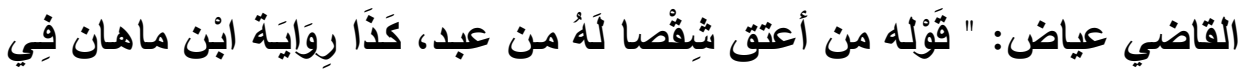

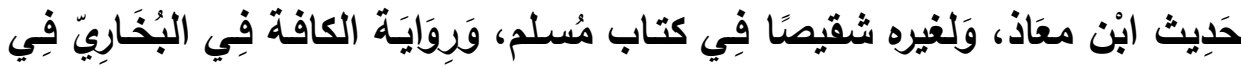

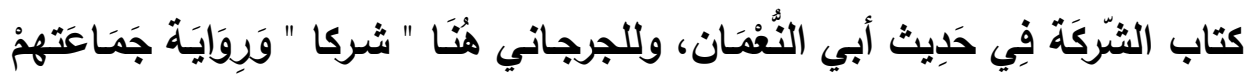

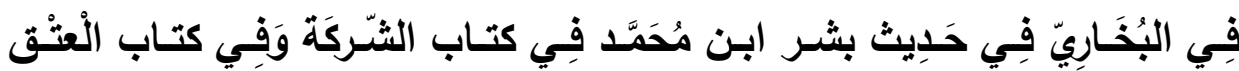

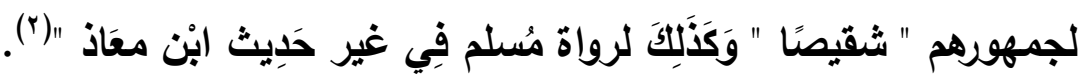

ومعنى الحديث إجمالا: أن من أعتق نصيبا لـه من مملوك مشترك بينه

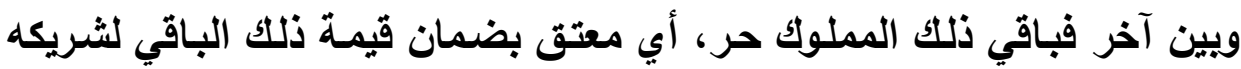

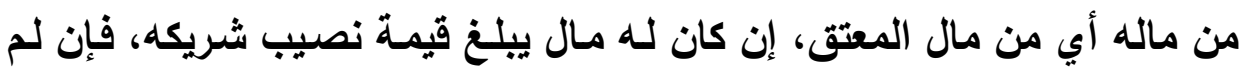

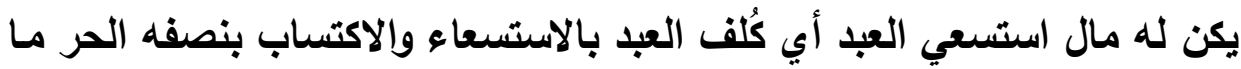

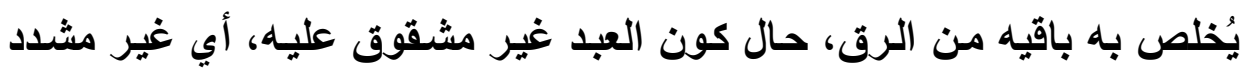

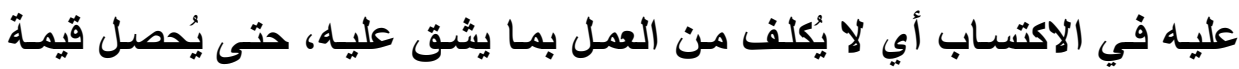

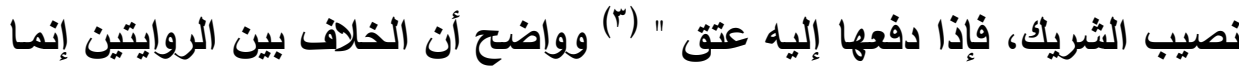

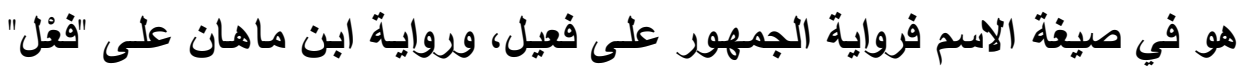

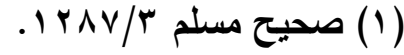

$$
\begin{aligned}
& \text { (r) مشارق الأنوار rov/r) }
\end{aligned}
$$

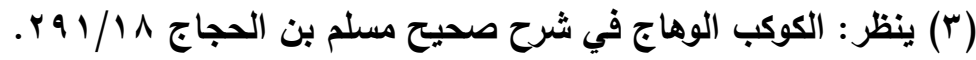




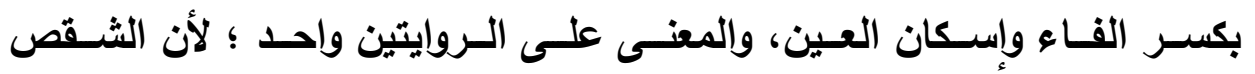

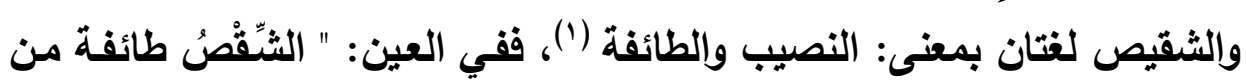

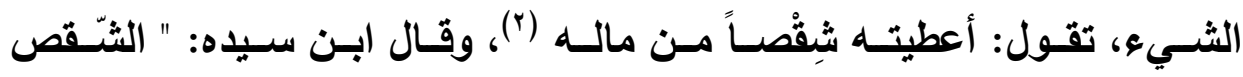

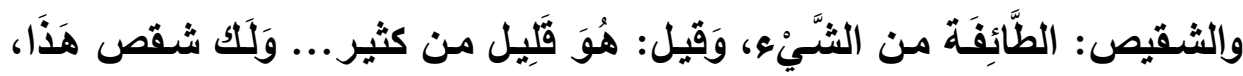

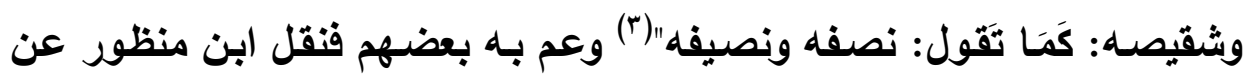

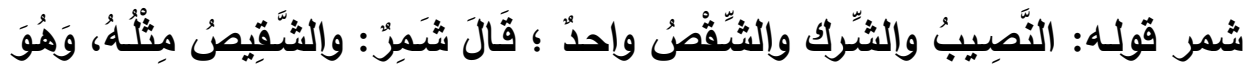

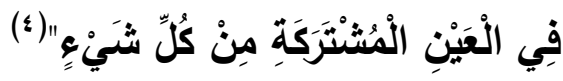

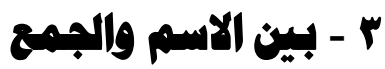

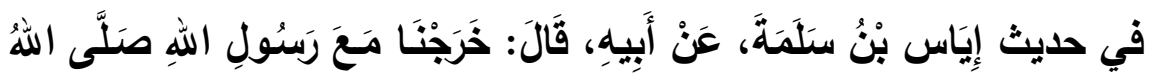

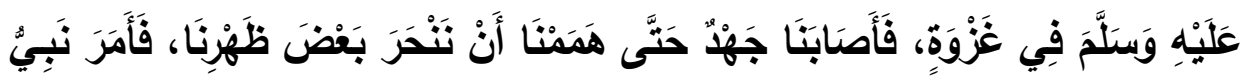

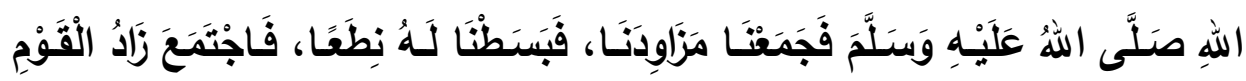

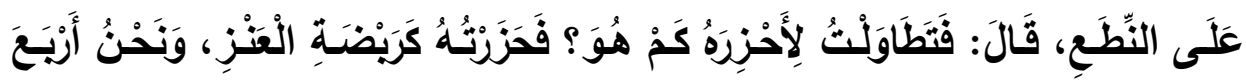

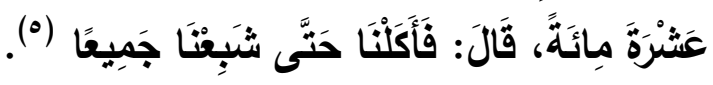

\section{الدراسة والتمليل}

قوله في الحديث " مزاودنا " جاء مرويا بثلاث روايات على النحو التالي

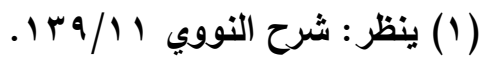

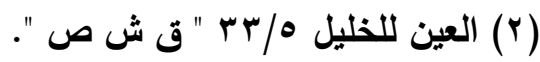

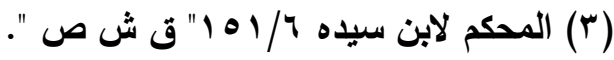

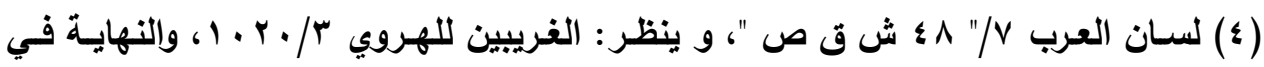

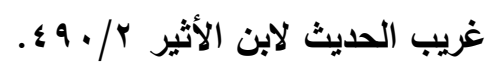

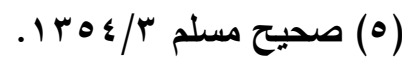


الرواية الأولي " هزاودنـا " وهى رواية المروزى، الروايـة الثانية " أزوادنـا"

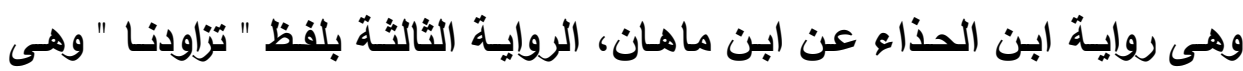
رواية أكثر الرواة عن مسلم (1). فرواية " مزاودنا " فعلى أنها جمع مزود بكسر الميم كمنبر، والمِزْوَدُ: هو

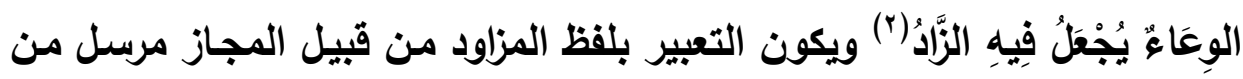
ذكر المحل وإرادة الحال.

وأهـا روايـة ابسن ماهـان " أزوادنـا " فعلى أنها جمع للفظ " زاد " قال ابن

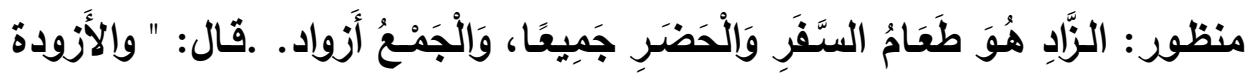

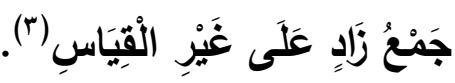

وأها رواية ” تزاودنا " فقد وردت مروية بفتح التاء وكسرها (๕)، فمن رواها بالفتح فعلى أنه مصدر بمنزلة التزويد، ومعناه: جمعنا ما تزودنا بـه في سفرنا

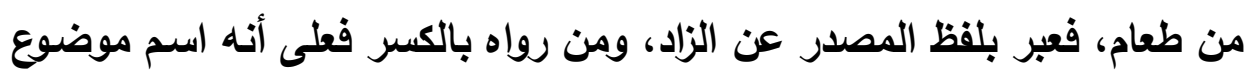

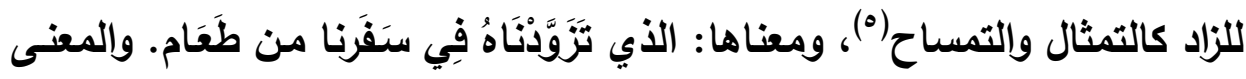

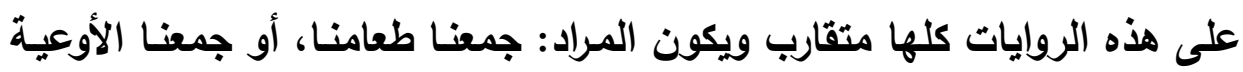

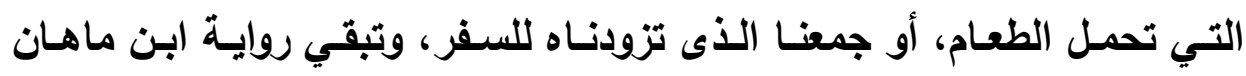

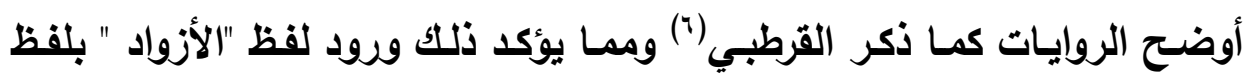

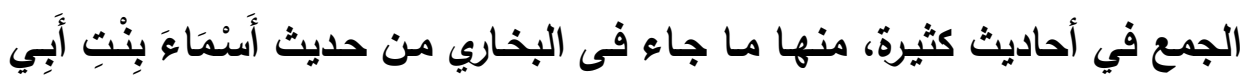

$$
\begin{aligned}
& \text { (1) ينظر: مشارق الأنوار / /؟ آس. }
\end{aligned}
$$

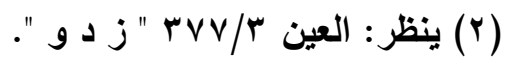

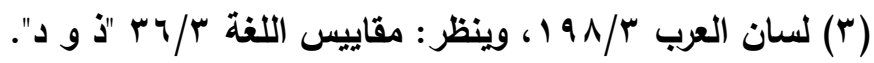

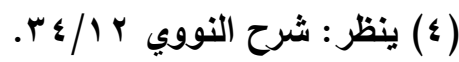

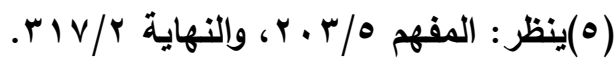

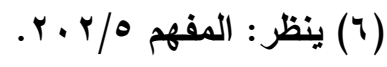




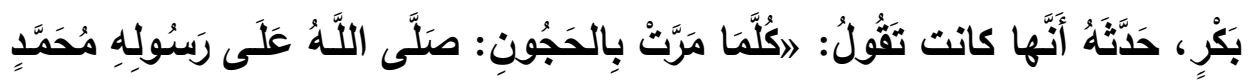

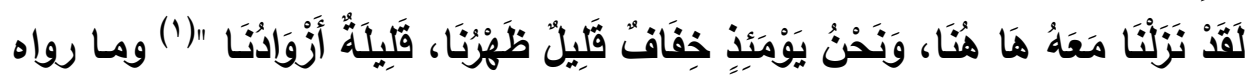

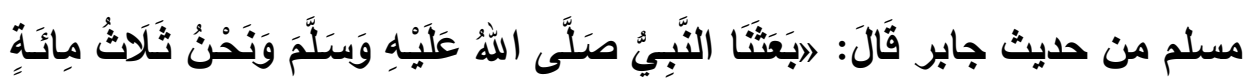

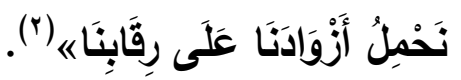

\section{ثانيا: اختاف الرواية في صيغ الأفعال 1 - فَعمل - أَفْعَل أ - " ققل وأققل "}

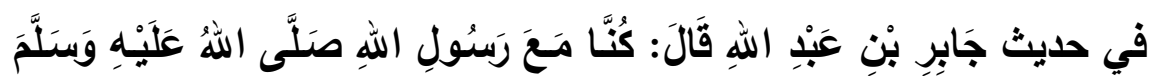

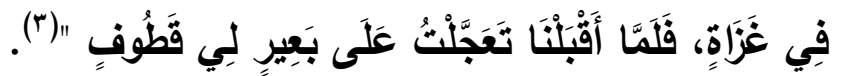

\section{الدراسة والتصليل}

قوله " أقبلنا "رواه جمهور الرواة هكذا " أقبلنا " بالباء، ورواه ابن ماهان "

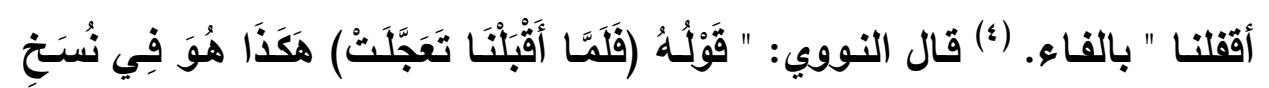
بِلَادِنَا أقبلنا، وكذا نقله القاضي عن رواية بن سفيان عن مسلم قال: وفي رواية

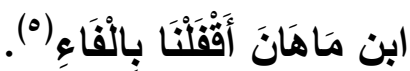

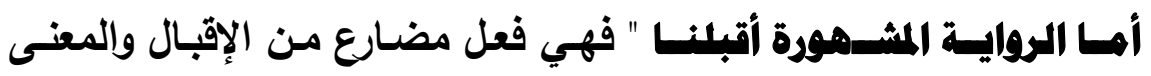

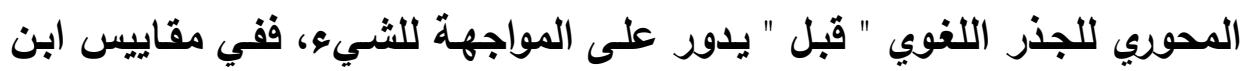

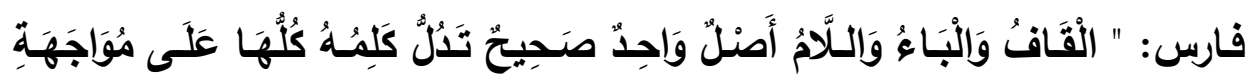

$$
\begin{aligned}
& \text { (1) صحيح البخاري V/r. }
\end{aligned}
$$

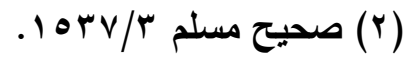

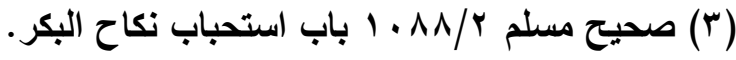

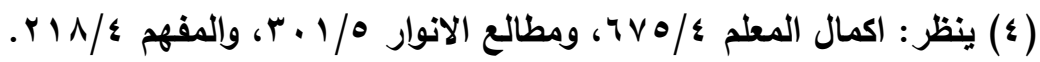

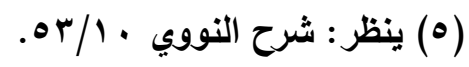




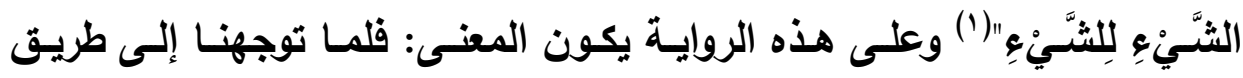

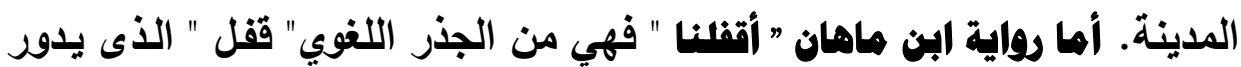

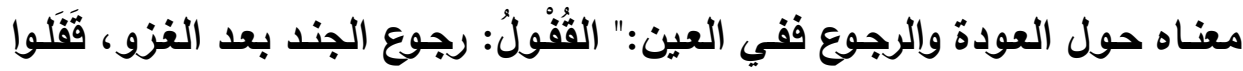

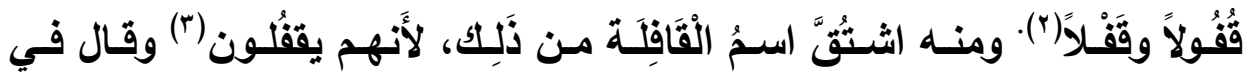

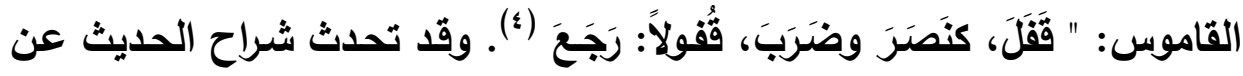

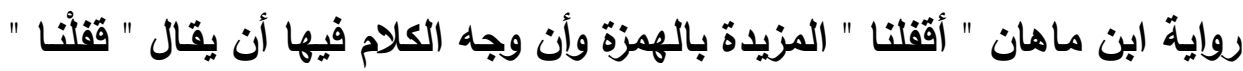

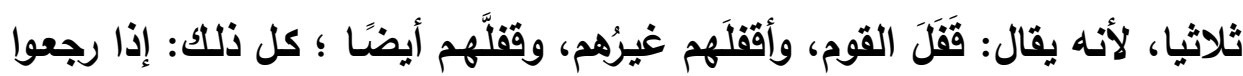

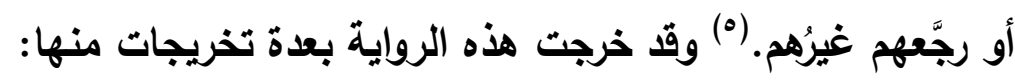
ا. يحتمل أن تكون الرواية " أققلَّا " بفتح اللام، أي أققلنا النبي - عليه السلام - المتقدم ذكره قبل.

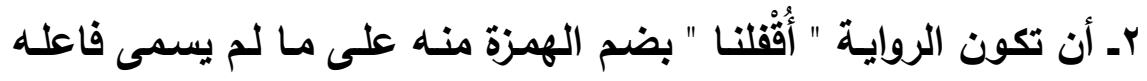

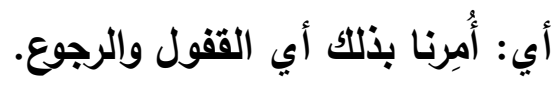

r - أن تكون: أققلْنا " بسكون اللام بمعنى أققل بعضنا بعضاً لأمر النبي - صلى الله عليه وسلم - إياهم بذلك وإذنه لهم فيه.

ع. ويجوز أن يكون " أققلنا " بمعنى: شرعنا في القفول، ودخلنا فيه. (")

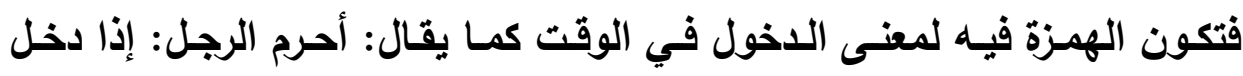

$$
\begin{aligned}
& \text { (1) مقاييس اللغة 10/01"ق ب ل ". }
\end{aligned}
$$

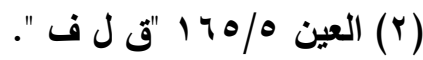

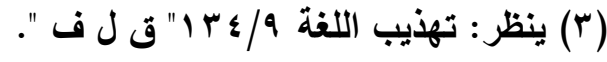

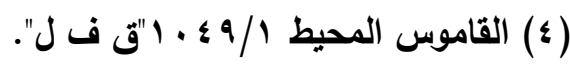

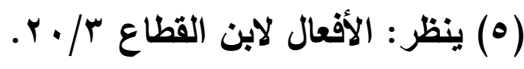

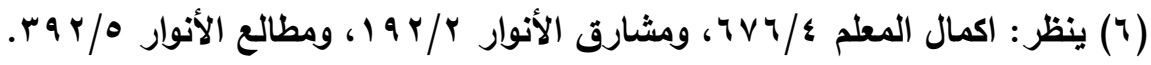


الحرم(")، ويهذه التخريجات لروايـة ابن ماهـان لَا يحُسب فِيها وهم على مَا قَالَ

بَعضهم (r)

\section{ب - بهر وأجهر - nمر}

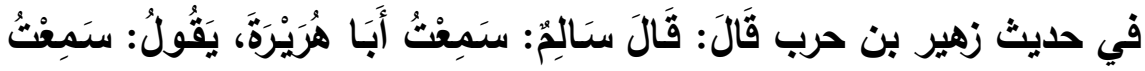

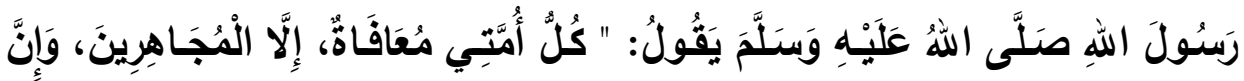

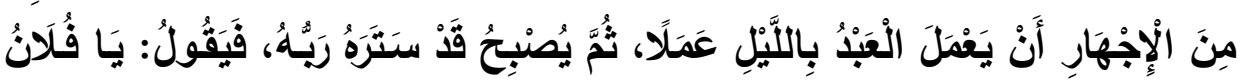

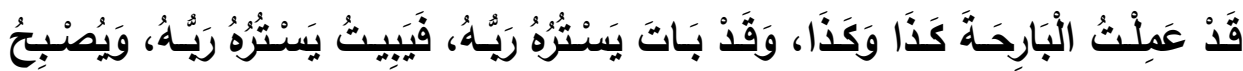

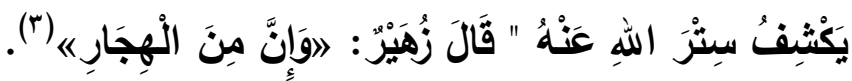

\section{الدراسة والتمليل}

الحديث في باب النهى عن هتك الإنسـان ستر نفسـه، وقد جاء قولـه " الإجهار " مرويا بعدة روايات على النحو التالي:

الأولى: روى بلفظ " الإجهار" وهى رواية كافة الرواة عن مسلم من الفعل

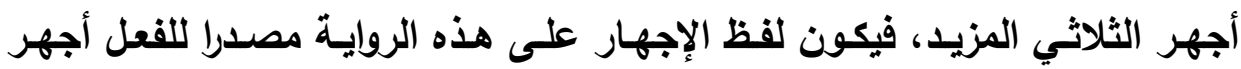
بمعنى أعلن. الثانيسة: رواه ابسن ماهـان " وإن من الجهار " من الفعل جهر

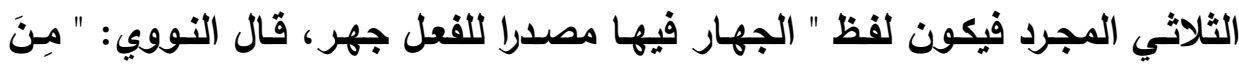

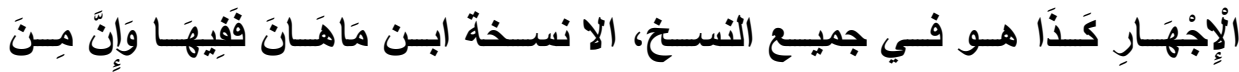

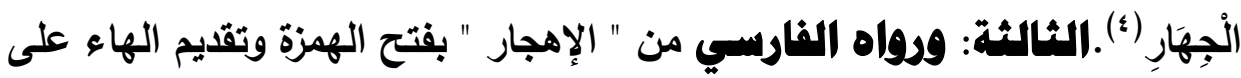

(1) ينظر : الكناش في فنى النحو والصرف TV/r/ (1)

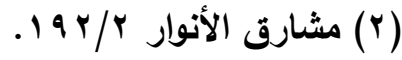

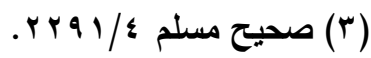

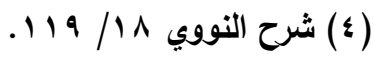


الجيم. ( "الزابعة: رواه زهير بن حرب شيخ مسلم " من الهجار " بتقديم الهاء على الجيم.

أمـا الروايتـان الأولـي والثانيـة فهمـا صحيحتان مـن جهة اللغـة ؛ لأنـه يقـال:

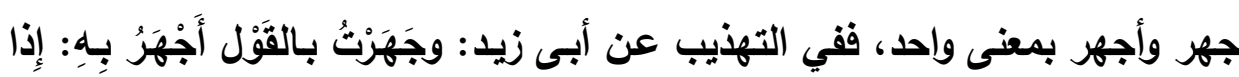

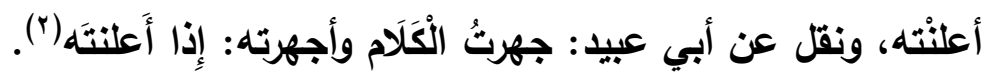

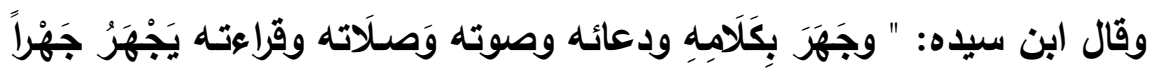

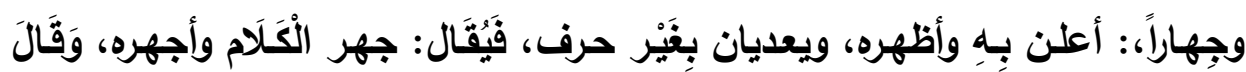

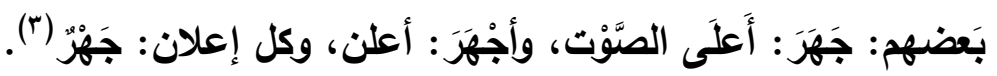
ومعنى الحديث على الروايتين: وإن من الإعلان والكشف أن يعمل الرجل عمـلا فيستره الله عليـه، ثم يصبح فيهتك سـتر الله عليه ويفضـح نفسـه فيقول عملث كذا وكذا.

وأمسا رواية من رواه " الإهجار" فقد خرجت على أنها مصدر للفعل أهجر بمعنى: أفحش في الكلام مأخوذة من الهُجر بضم الهاء، فهي العين " الهُجْر:

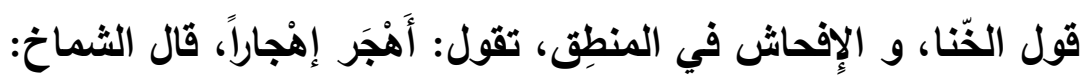

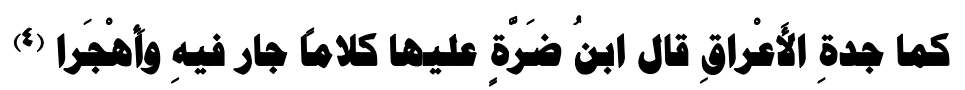

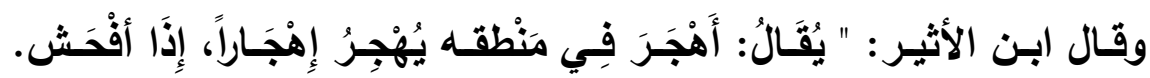

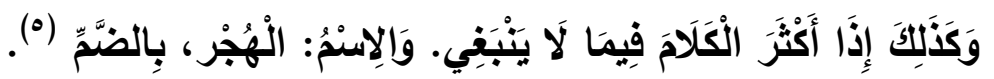

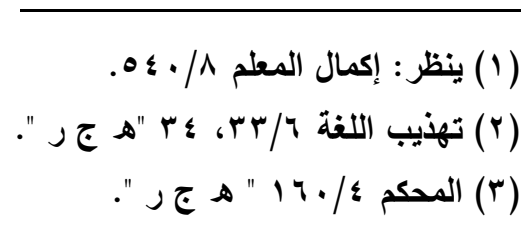

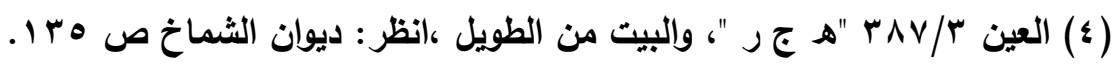

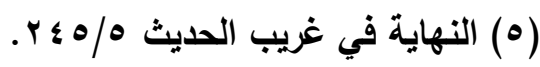


أما رواية من رواه " الهجار " بتقديم الهاء على الجيم، فقد وصفت بأنها على خـلاف الصـواب، قـال القاضـي في المشـارق: " وأمسا الهجـار فبعيد لفظـا

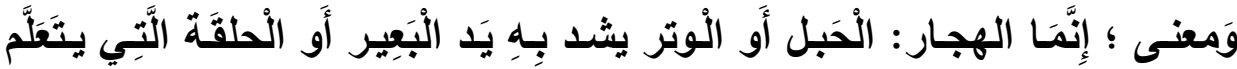

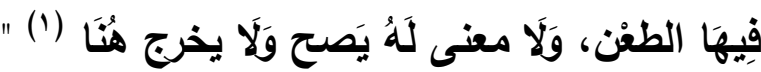

وقد صححها بعضهم من جهة أن يكون الهجار لغة في الإهجار بمعنى

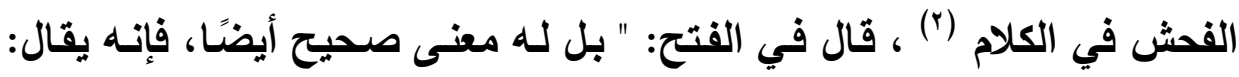
هجر، وأهجر: إذا أفشش في كلامسه، فهو مثٔل جهر، وأجهر، فما صح في هذا صح في هذا، ولا يلزم من استعمال الهجار بمعنى الحبل، أو غيره أن لا يستعمل

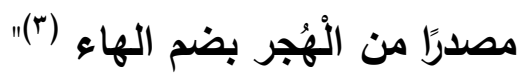

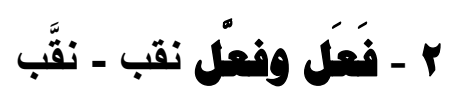

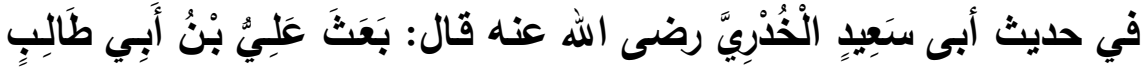

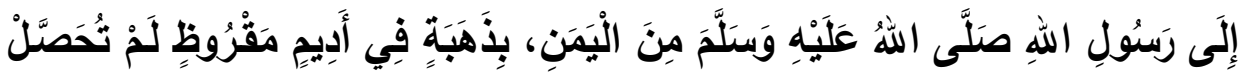

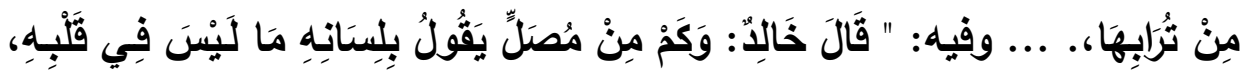

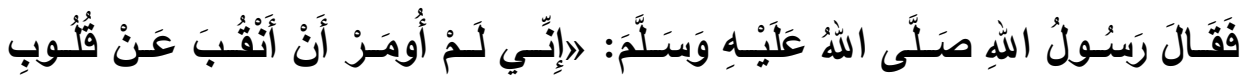

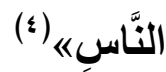

\section{الدراسة والتمليل}

روى قولهه " أنقُب " بفتح الهمزة وسكون النون وضم القاف وفتح الباء،

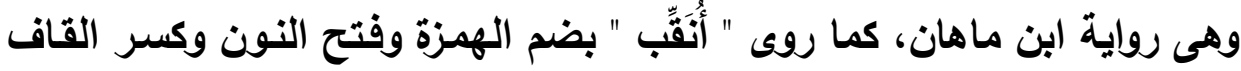

$$
\begin{aligned}
& \text { (1) مشارق الأنوار 17r/1. }
\end{aligned}
$$

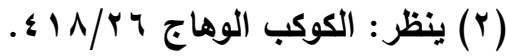

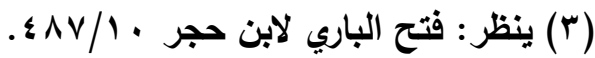

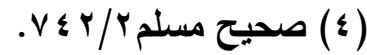


المشدة وفتح الباء في آخره وهى رواية غيره، قال فى مطالع الأنوار: قولهه: "وَلََمْ

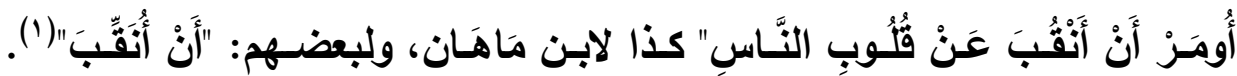

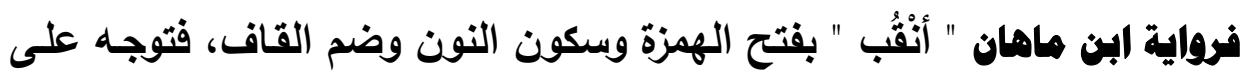

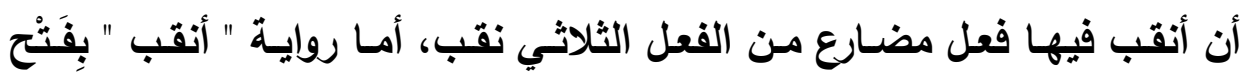

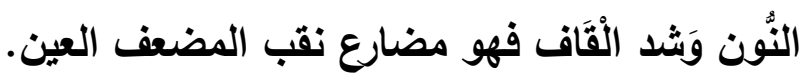

ويبدو الخلاف بين الروايتين من جهة التباين في صياغة المضارع من الفعل نقب على التجرد والزيادة بالتضعيف، والمعنى على الروايتين متقارب ؛ لأن أنقب وأنقب على الرويتين من الفعل نقب الذى يدور معناه حول: فتح شيء

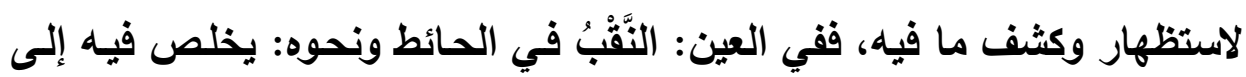

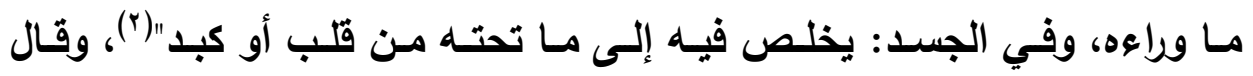

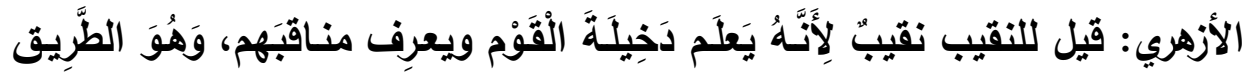

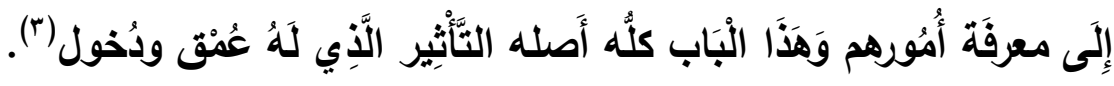
وعلى هذا فالمعنى على الروايتين متحد، فالروايتان جاءتا على ما يجئ

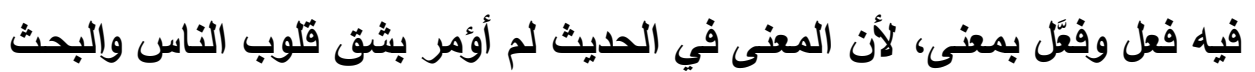
والتفتيش عما بداخلها لأن الله هو الذى يتولى السرائر.

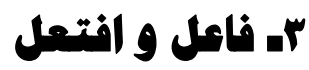

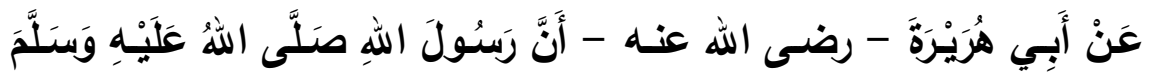

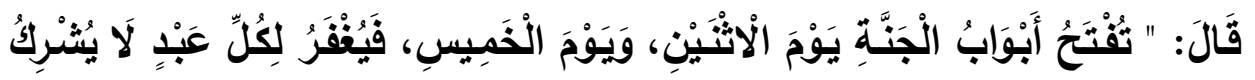

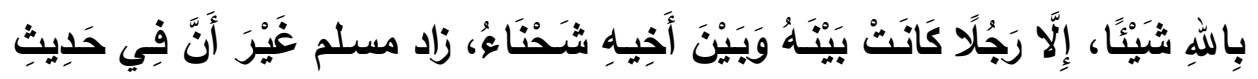

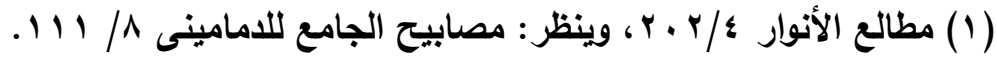

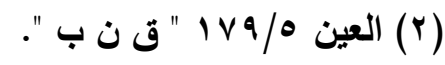

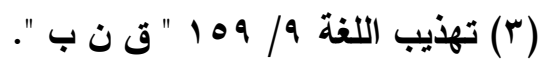




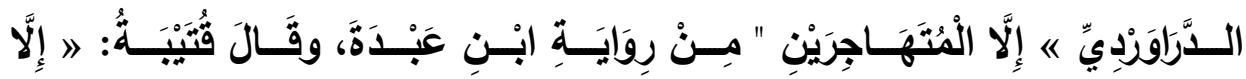

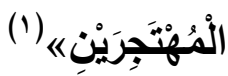

\section{الدراسة والتمليل}

قولـها" إلا المتهـاجرين" رواه كافـة الرواة كذلك، وَعنــــــنـن ماهـان "بلفظظ "

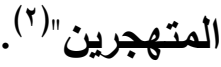

والخـلاف بـين الروايتين راجـع لاختـلاف صـيغة الفعل المشـتق منـهـ كلـ

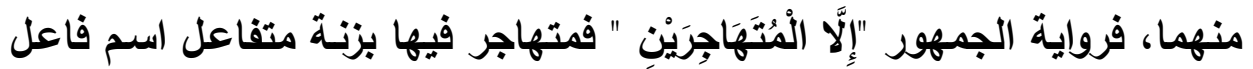
من الفعل " هاجر" بوزن فاعل من الهَجر بمعنى: المجافاة والترك كما يقال قاتل

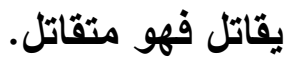

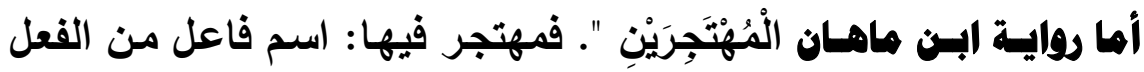
اهتجر" بوزن افتعل كما يقال احتكم فهو محتكم.

ومسن العلمـاء من ذهب إلى القول إلى عدم التفرقة بين الصيغتين في المغنى وأنهما بمعنى واحد ويعنى بهما المتصـارمين المتقاطعين، ويؤيده مـا في الأساس من أنه يقال: " هجره وهاجره واهتجره(")، وقال اليفرنس في تفسير قولهـ

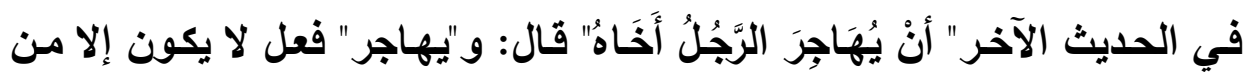

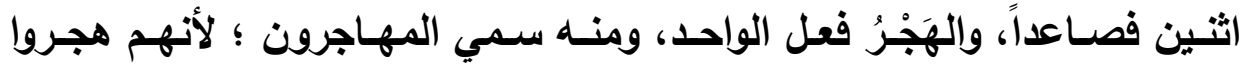

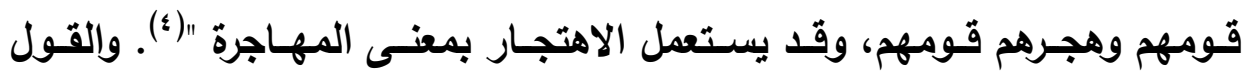
بترادف الصيغتين في المعنى حسن يمكن حمل الحديث عليه، كما أنه يمكن أن

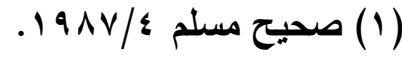

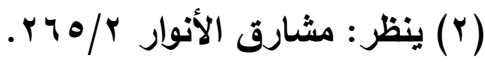

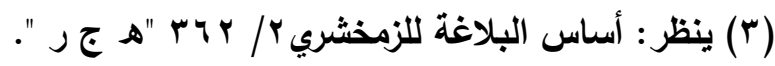

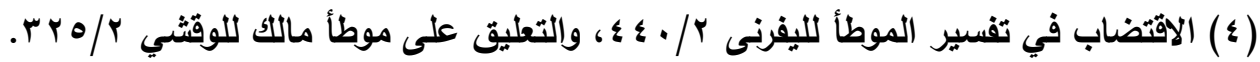




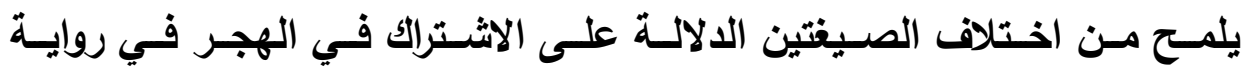

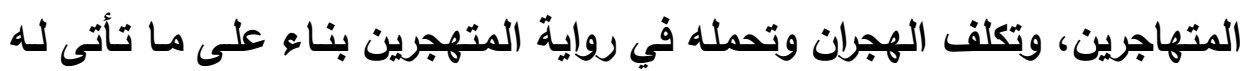

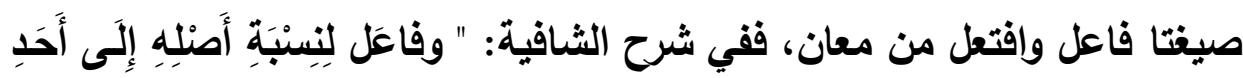

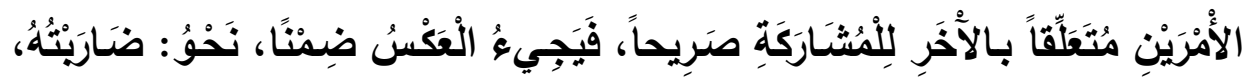

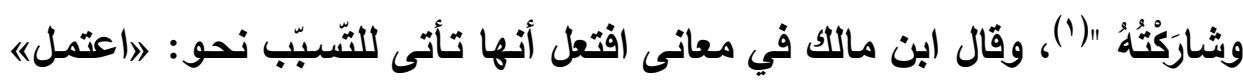

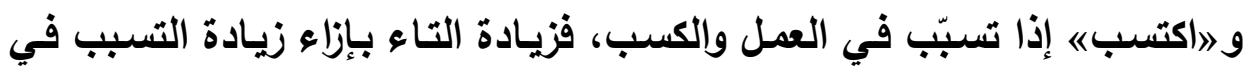

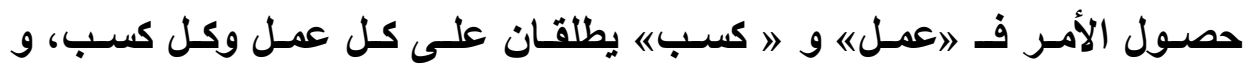

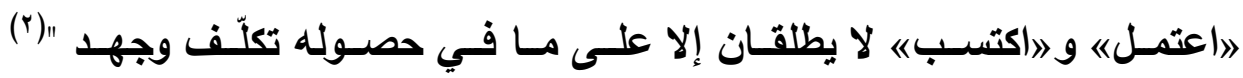

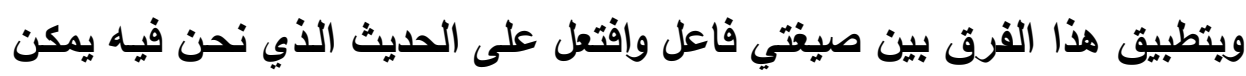

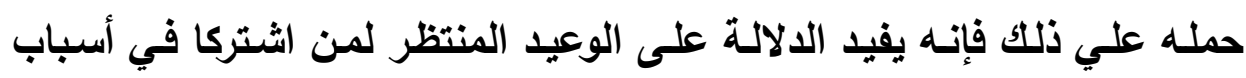
الهجر، أو تكلفه بالمعاداة والقطيعة(r).

\section{ثالثا: اختلاف الرواية بافتلاف الاشتقاق}

\section{اـ يكهرون ، يكرهون}

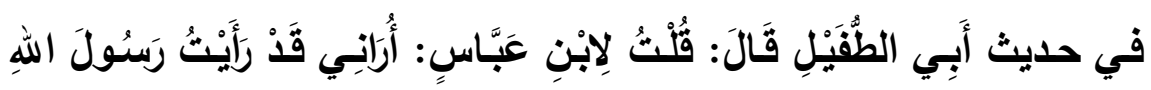

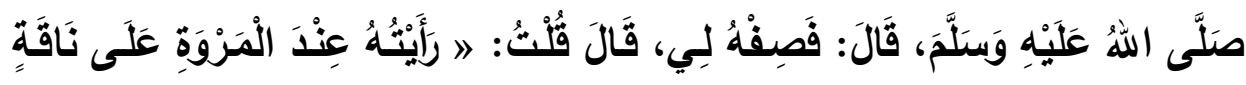

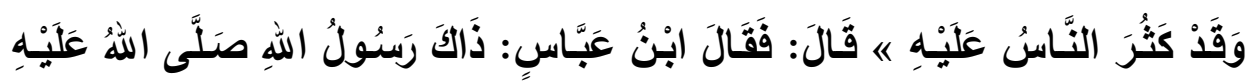

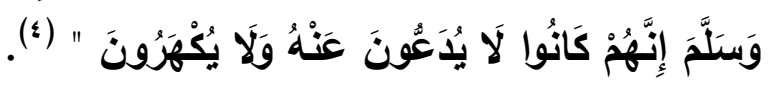

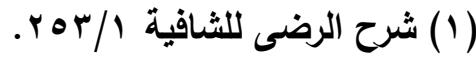

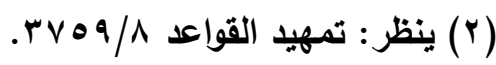

$$
\begin{aligned}
& \text { (Y) }
\end{aligned}
$$

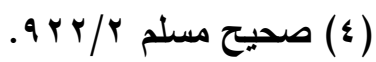




\section{الدراسة والتمليل}

الحديث في سياق بيـان حلمـه صـلي الله عليه وسـلم، وأن النـاس كـانوا

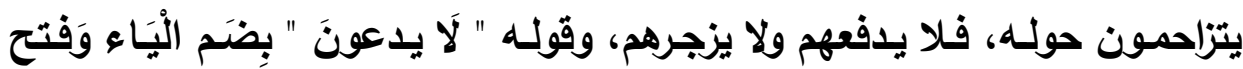

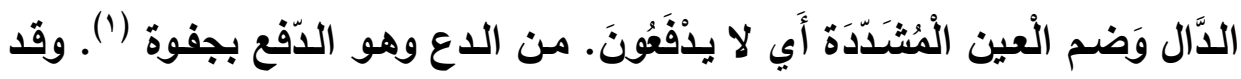
روي قوله في الحديث " يكهرون " بروايتين:

الأولي: رواية ” يكرهون " بتقليم الراء على الهاء وهى رواية الفارسي كما

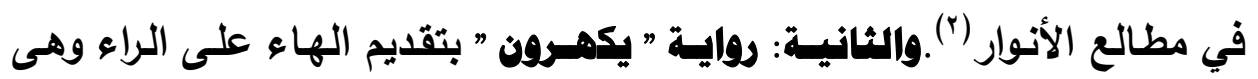
رواية العذري و ابن ماهان كما في إكمال المعلم("). أمـا الروايـة الأولـي: " يكرهون " فهـي مـأخوذة من الإكراه والمشقة يقـال

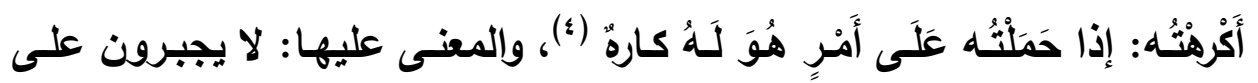

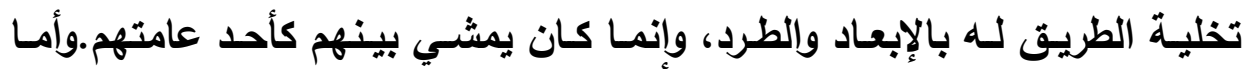

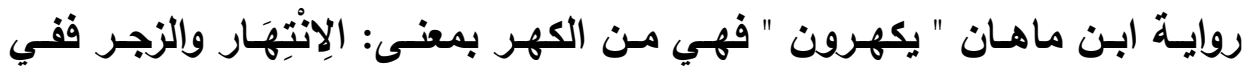

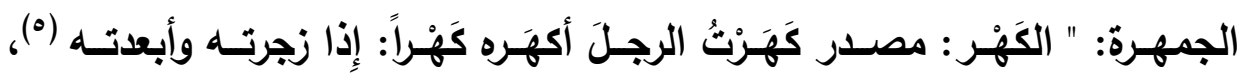

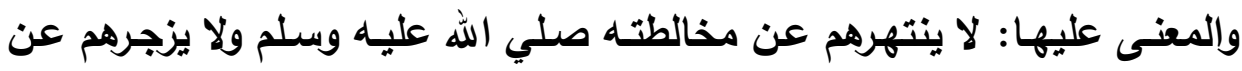
الالتفاف حوله أحد من سعة حلمه

وعلى الرغم من تقارب المعنى على الروايتين، فقد صوب القاضي عياض

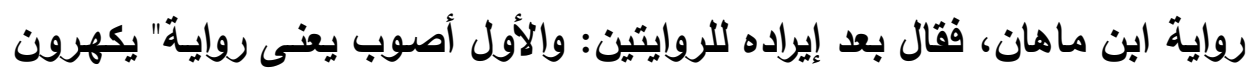

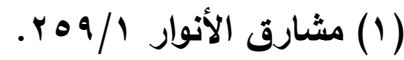

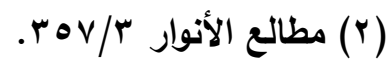

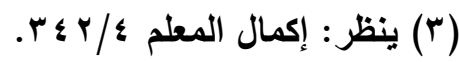

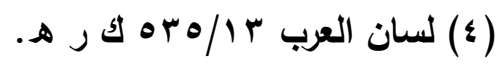

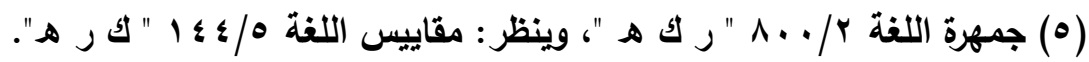


" بتقديم الهاء. (') وكذا صويها ابن قرقول(†). وما يثـهـ بقوة هذه الروايـة مـا

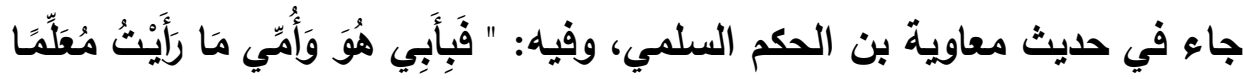

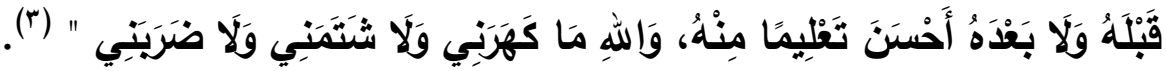

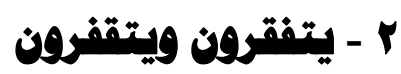

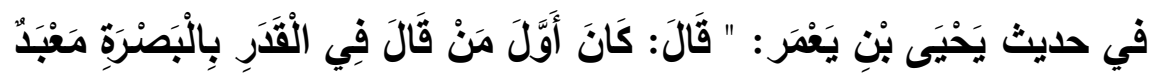

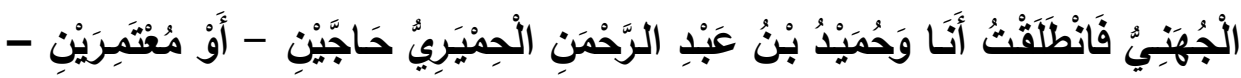

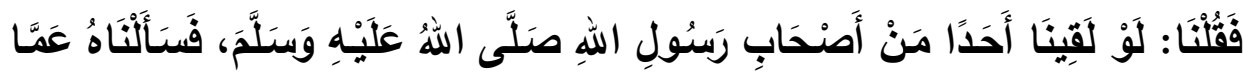

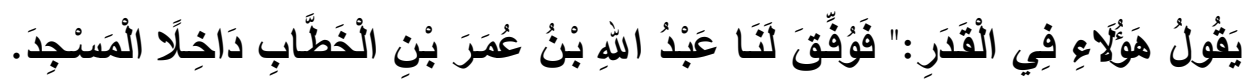

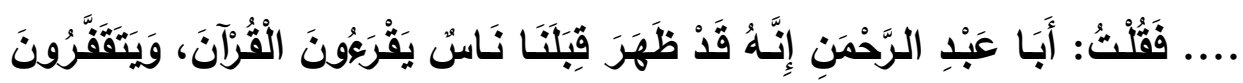

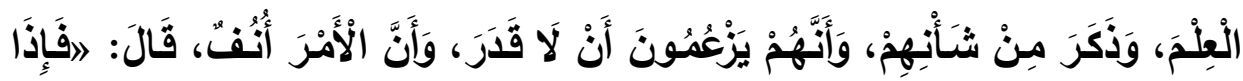

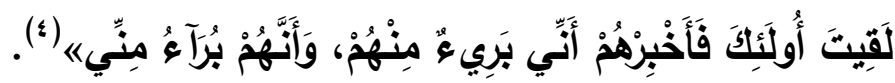

\section{الدراسة والتمليل}

قولـه في الحديث السـابق " يتقفرون " جاء مرويًا بعدة روايـات: منها " يتقفرون " بتقديم القـاف على الفـاء، ورواه بعضهـه " يقتفرون " بقـاف سَكَكِنة

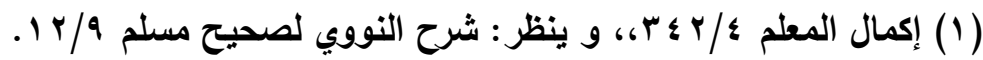

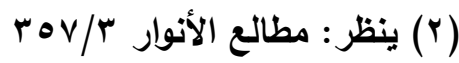

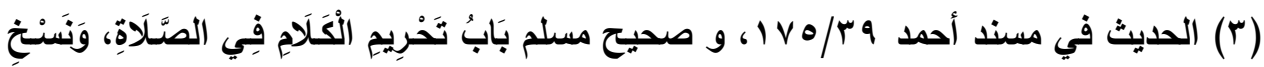
مَا كَانَ مِنْ إِبَاحَتِهِ

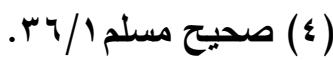




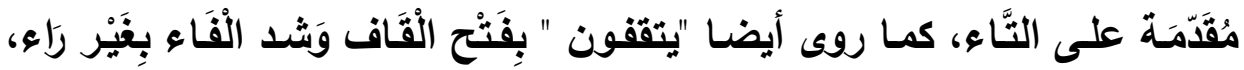

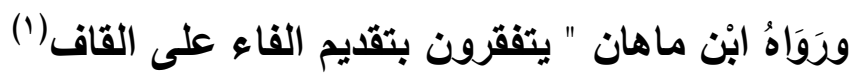

فأها رواية " يتقفرون " بتقيم القاف على الفاء فهي أثـهر الروايات وهى

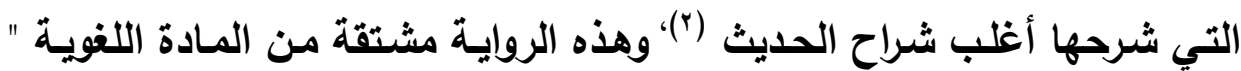

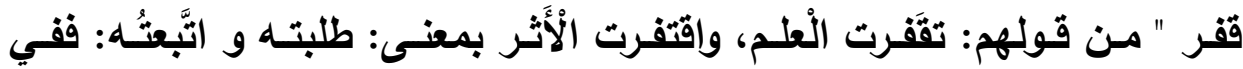

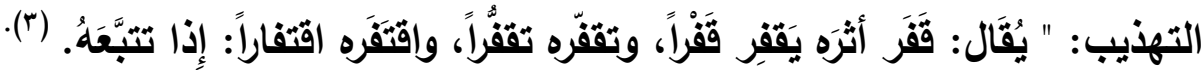

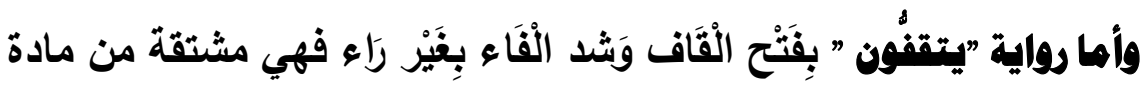

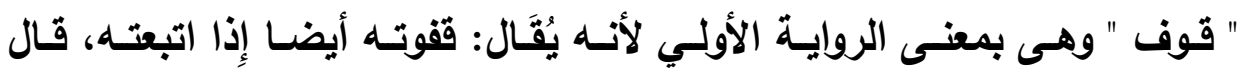

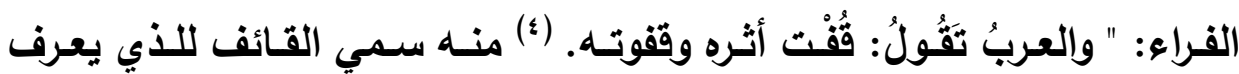

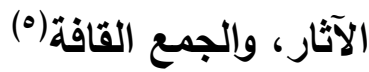

وأها رواية ابن هاهان " يتفقرون " بتقليم الفاء على القاف فجذرها اللغوي " فقر " وأصلها من قولهه: فقرتُ البئر: إذا حفرتها لاستخراج مائها، وَمِنْهـه جاءت

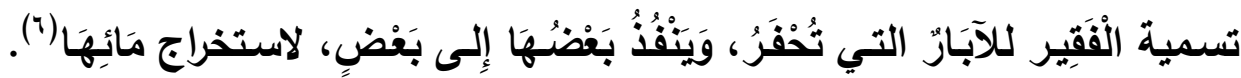

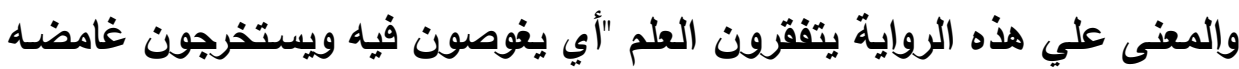
ويفتحون مغلقة ومبهمة.

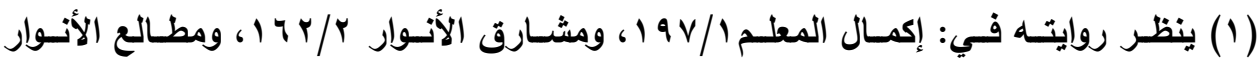

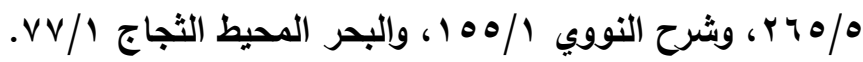

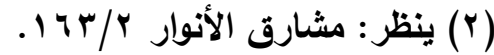

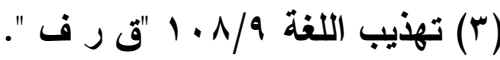

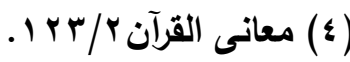

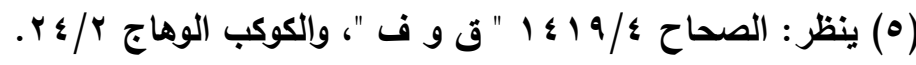

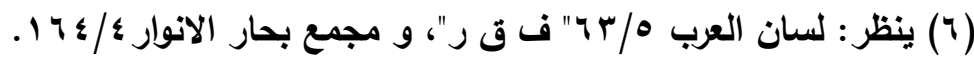


وقد صحح القاضـي عياض هذه الروايـة ووصفها بأنها الأليق بمعنى

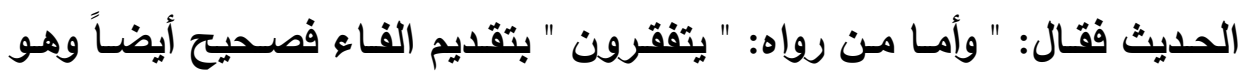

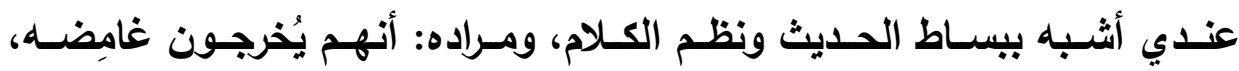

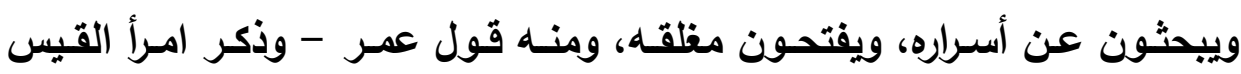

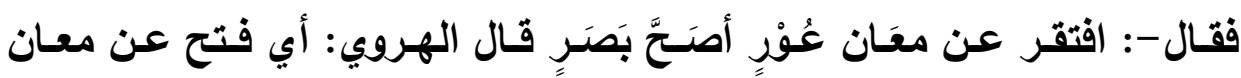

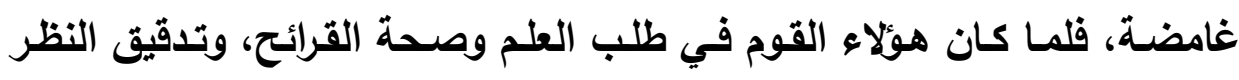

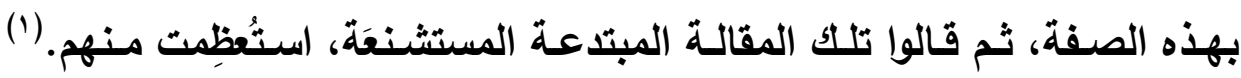
ومعنى هذا الكلام أن سياق الحديث يدعم رواية ابن ماهان ويقويها.

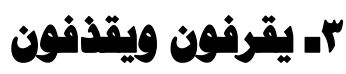

في حديث عبد الله بن عباس قَالَ: " أَخْبَرَبِي رَجُلْ مِنْ أَصْحَابِ النَّبِّيّ صَلَّى

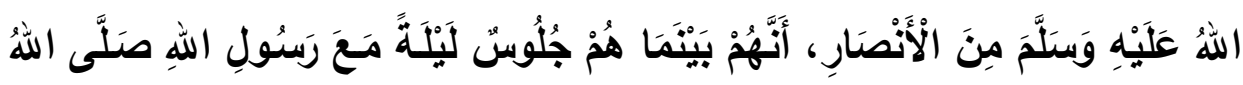

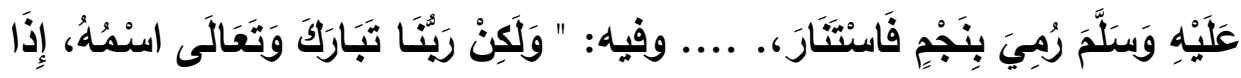

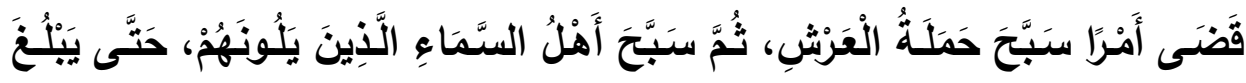

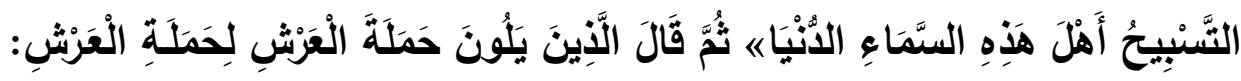

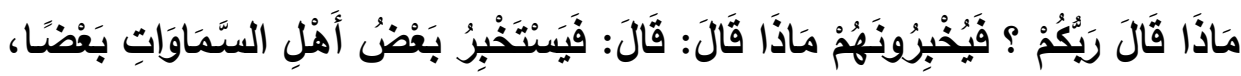

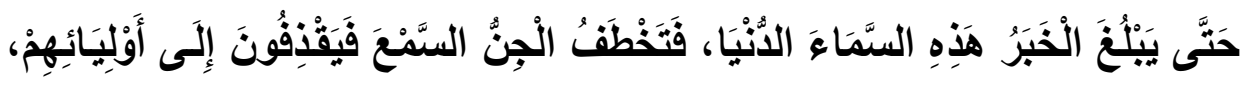

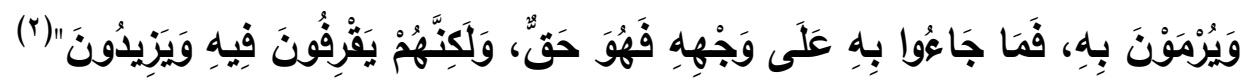

\section{الدراسة والتمليل}

الحديث في باب تحريم الكهانة وإتيان الكهان، وقوله في الحديث " يَقْرفِونَ

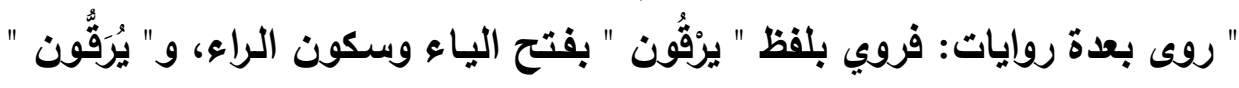

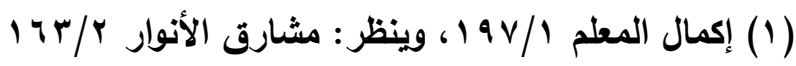

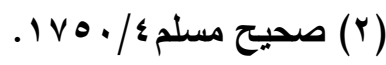


بضم الياء وفتح الراء وتشديد القاف (')، ورواه الجلودي " يقذفون " بالذال "(ז) ورواه ابن ماهان " يقرفون " بالراء(ז).

أها رواية" يرقَون " بفتح الياء وسكون الراء وفتح القاف، ورواية" يرقُّون " بضم الياء وفتح الراء وتثديد القاف، فمعناهما واحد، وهو الزيادة، وهما مشتقان من الفعل " رقي بمعنى صعد، ولا فرق بينهما سوى أن أحد اللفظين مأخوذ من الفعل المضـفف والآخر على أصـله مسن الفعل المجـرد، قـال الخطابي " قولـهـ:

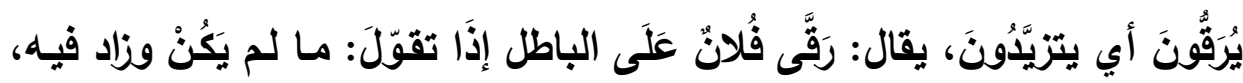

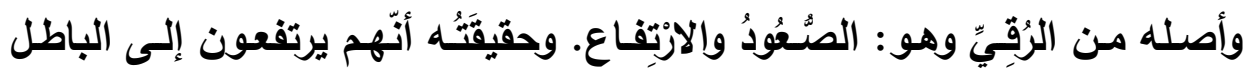

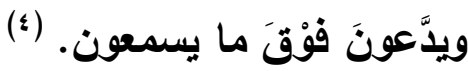

وأها رواية ” يقذفون ” بالذال فهي مشتقة من الجذر اللغوي قذف " الذى

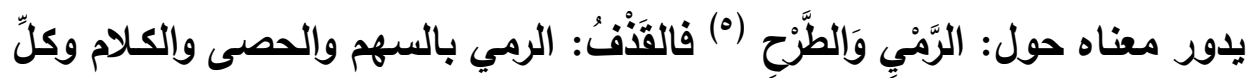

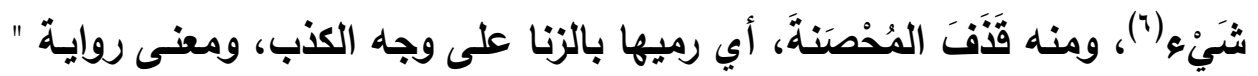

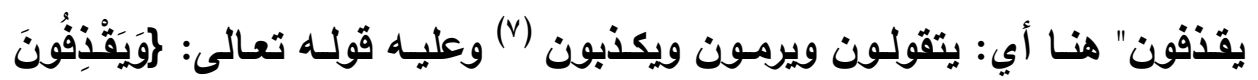
بِالْغَيْبِ أبي يقولون ما لا يعلمون (^).

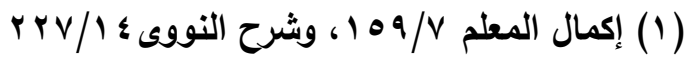

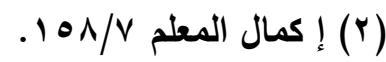

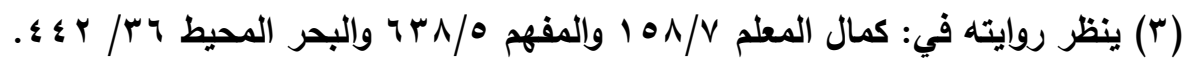

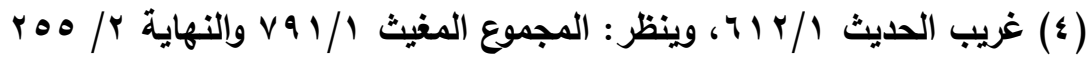

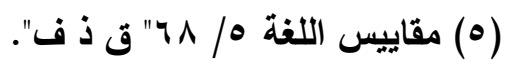

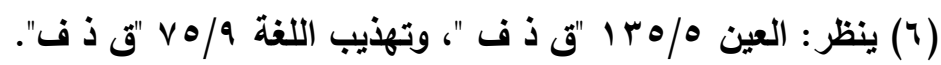
(V)

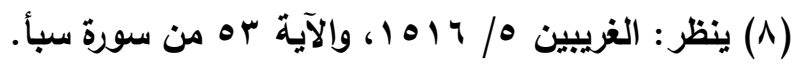


وأها رواية ابن ماهان " يقرفون " فهي مشتقة من الجذر اللغوي " قرف "

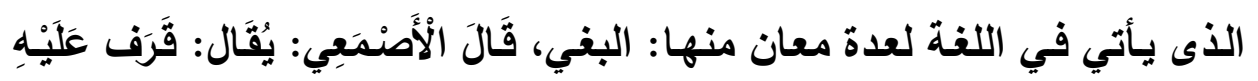

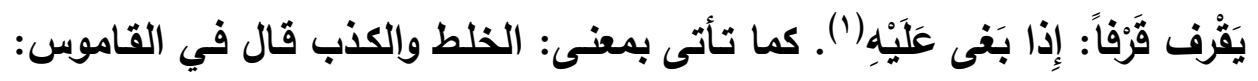

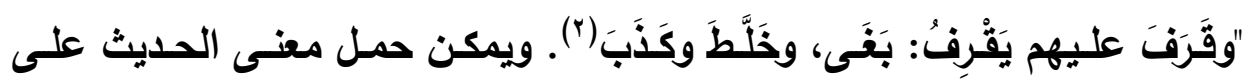

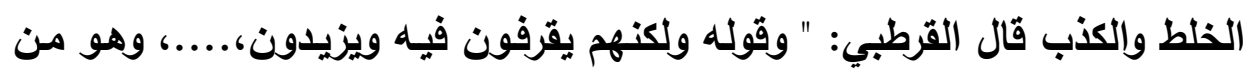

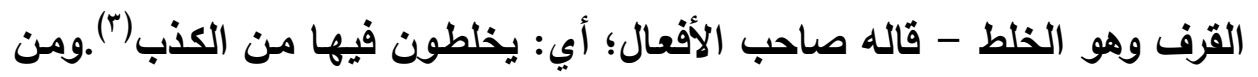

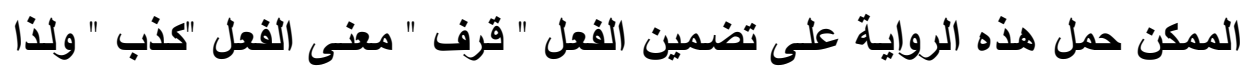

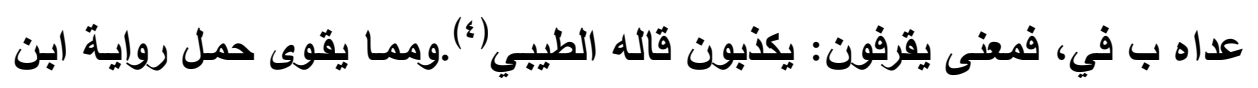

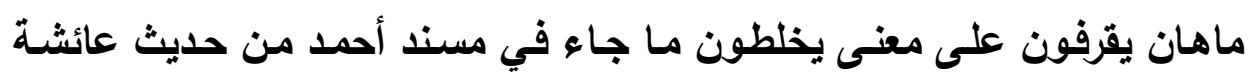

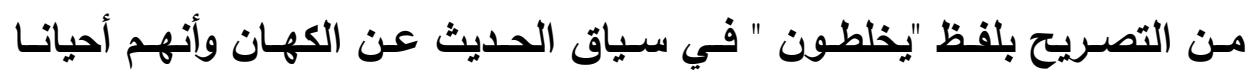

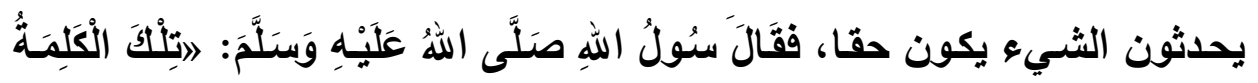

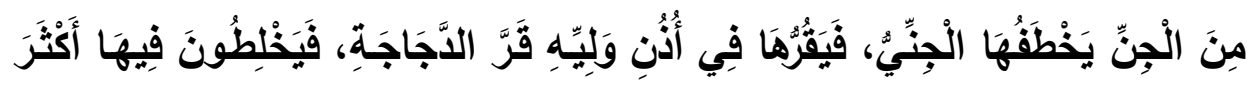

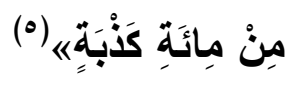

$$
\begin{aligned}
& \text { ع - غفره - صغره }
\end{aligned}
$$

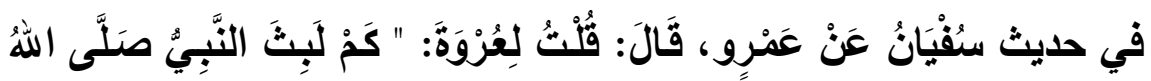

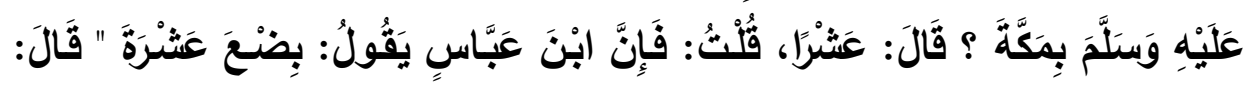

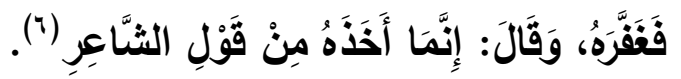

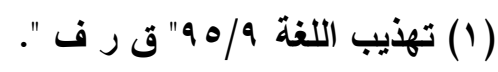

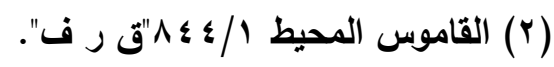

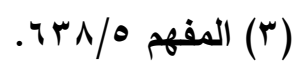

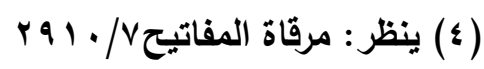

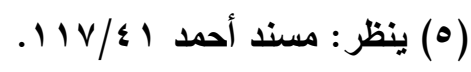

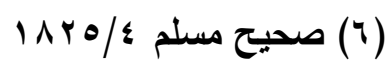




\section{الدراسة والتمليل}

الحديث في سياق سؤال عمرو بن دينار عن مدة إقامته صلي الله عليه

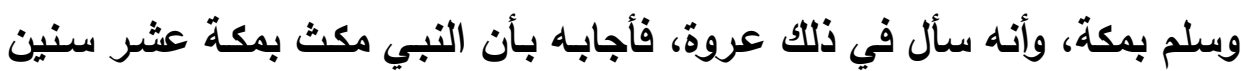

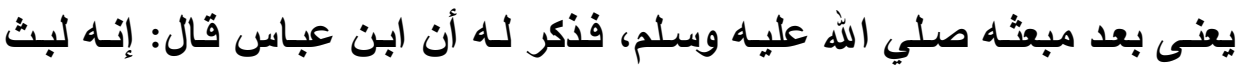
بضع عشرة سنة، فأنكر ذلك. وقوله " فغفره " رواه الجلودي بالغين والفاء، ورواه

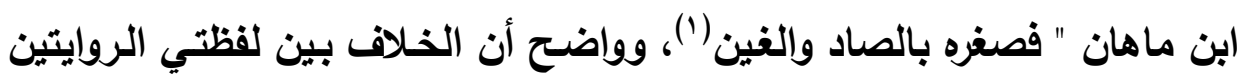

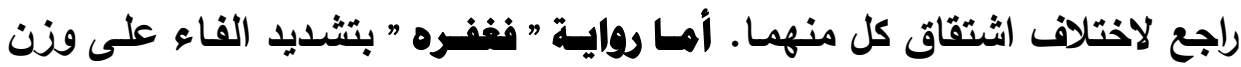

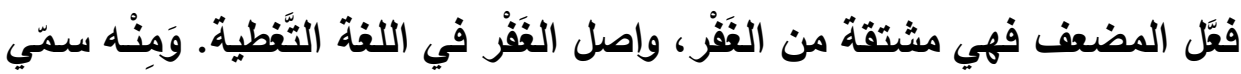

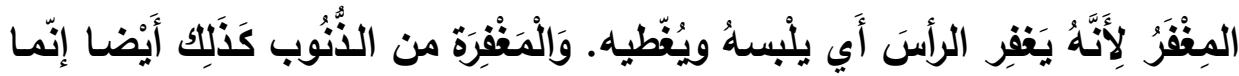

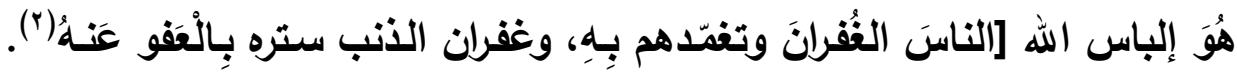

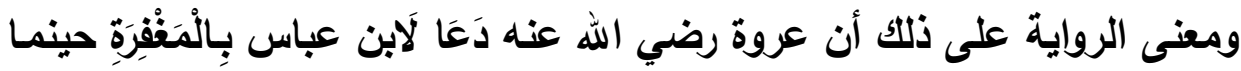

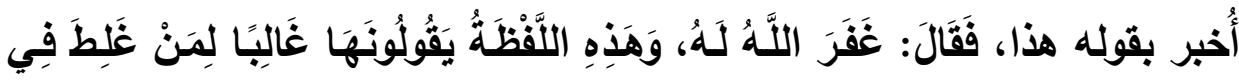

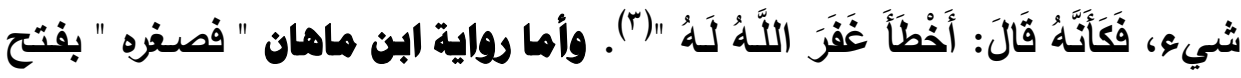

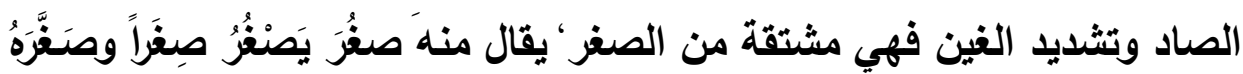

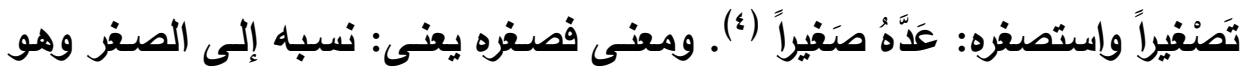

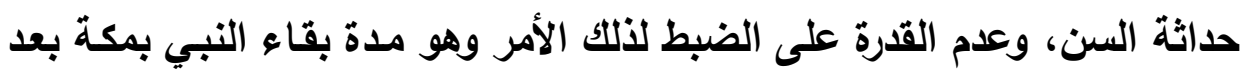

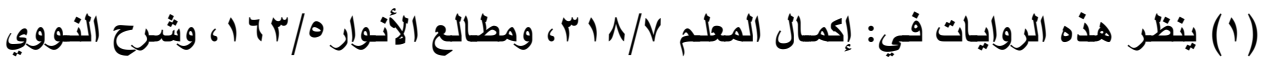

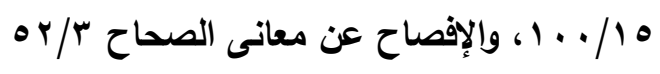

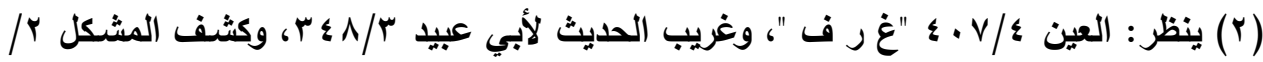
r. ros

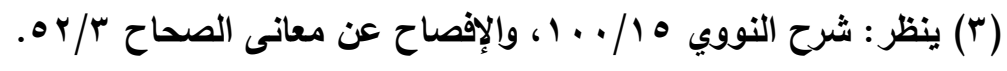

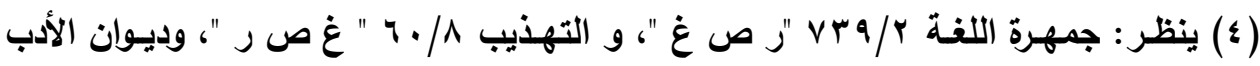

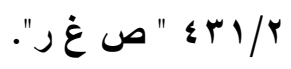


المبعث وقبل الهجرة.. وهو ما أثار إليه القرطبي بقوله: فصغَّره من الصغر، أي:

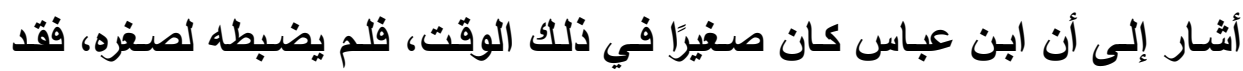

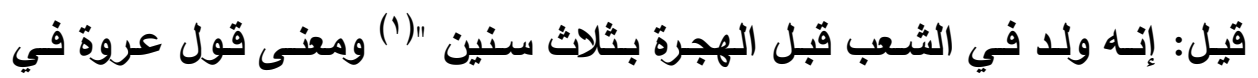

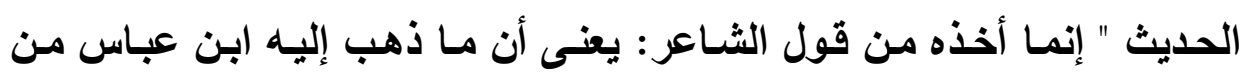

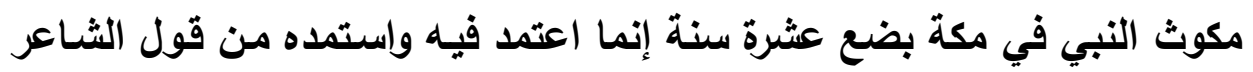

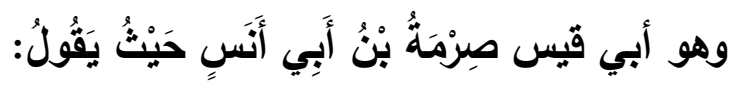

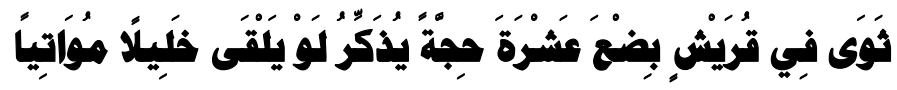

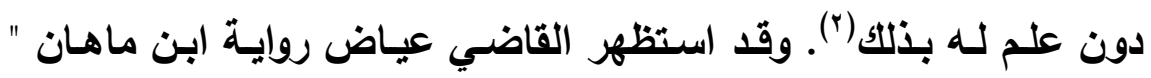

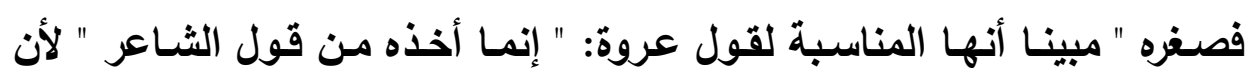

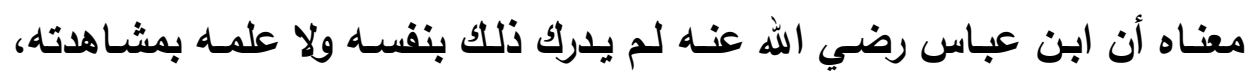

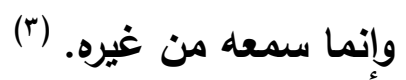

والذي عليه جمهور أهل العلم أن النبي _ صلى الله عليه وسلم ـ أقام

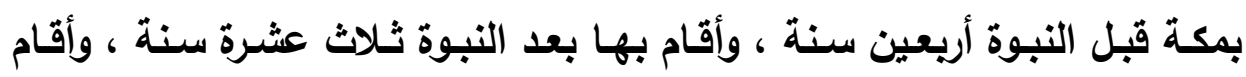

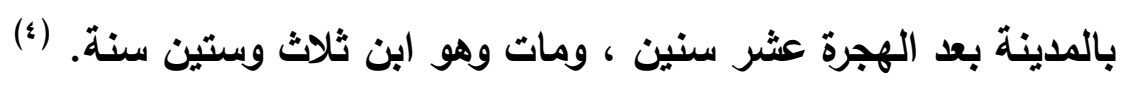

(1) المفهم (Y) 1 (1)

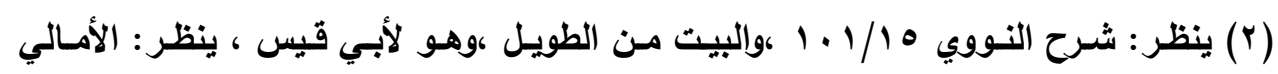

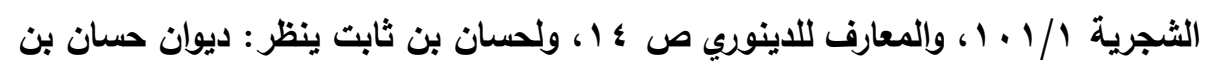

$$
\begin{aligned}
& \text { ثابت ص V Y }
\end{aligned}
$$

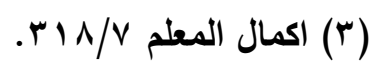

(£) ينظر: البداية والنهاية لابن كثير ،حققه ودقق أصوله وعلق حواثيه /علي شيري N/10. 


\section{المبحث الثالث: المتوى التركيبي}

تههيــد: المستوى التركيبي أو النحوي " هو ثالـث مستويات التحليل

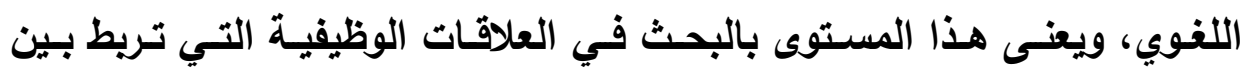
الكلمات أو المفردات داخل التركيب اللغوي الواحد. وقد تضمنت رواية ابن ماهدان لأحاديث صحيح مسلم على عدة مسائل تركيبة:

\section{أولا: الاختلاف في الإمراب}

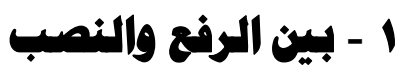

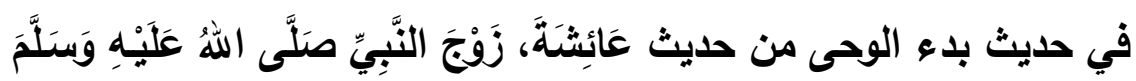

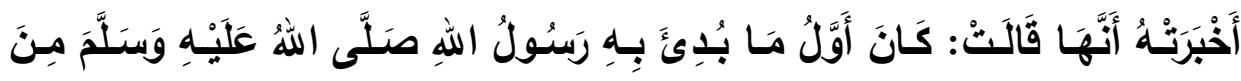

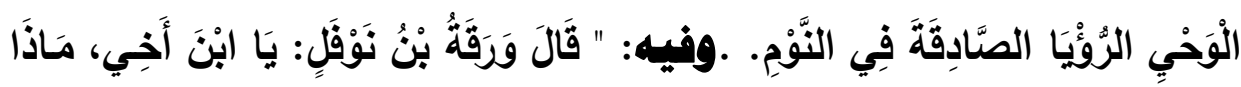

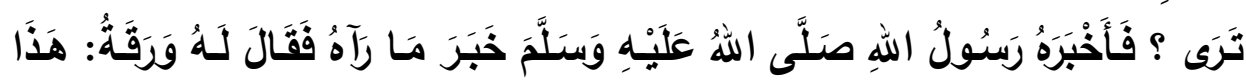

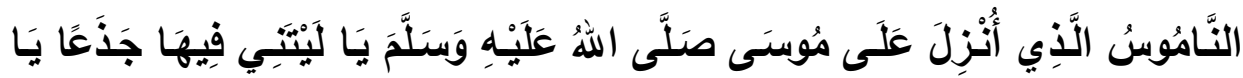

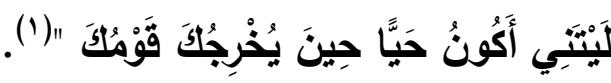

\section{الدراسة والتمليل}

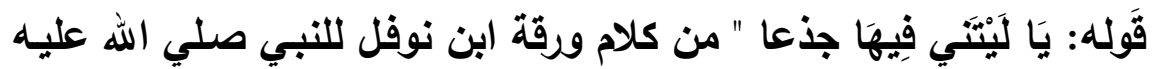

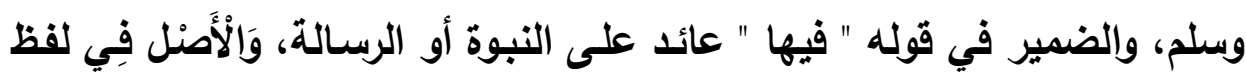

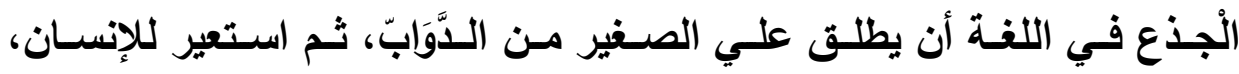

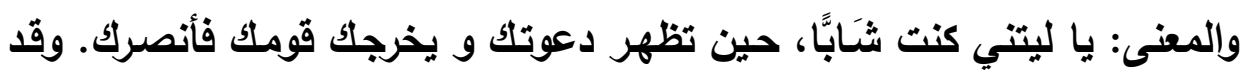

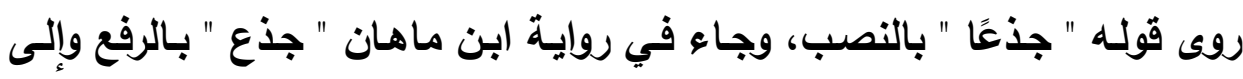

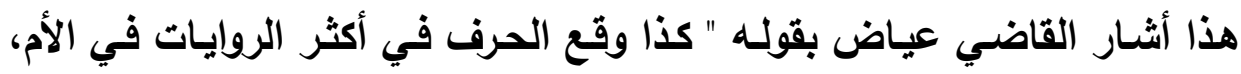


وفى كتاب البخاري" جذعاً " بالنصب، ووقع هنا عندنا لابن ماهـان: جذَعٌ "( ).

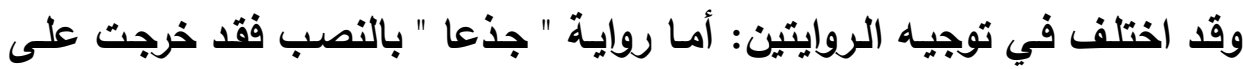

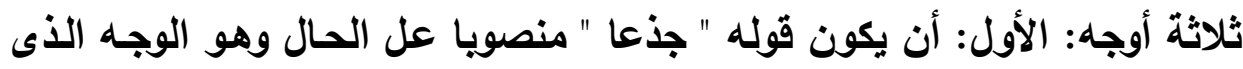

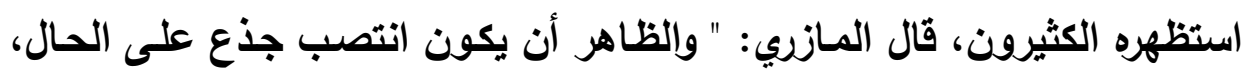

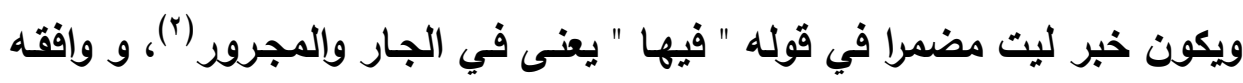

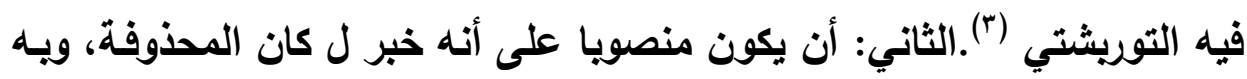

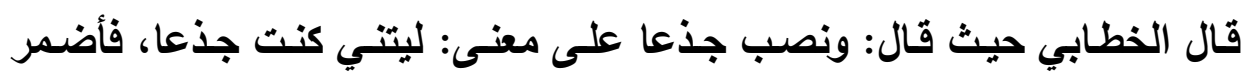

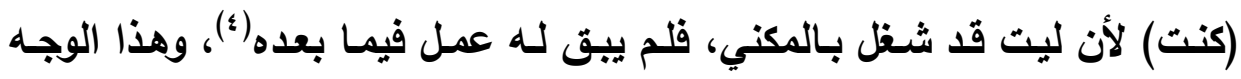

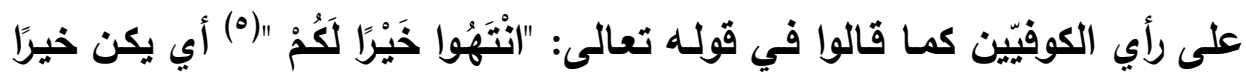

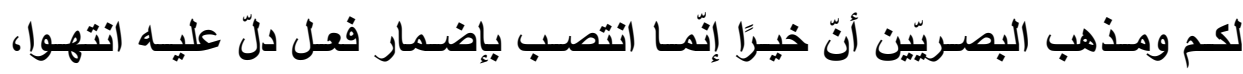

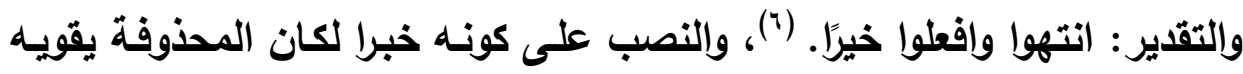

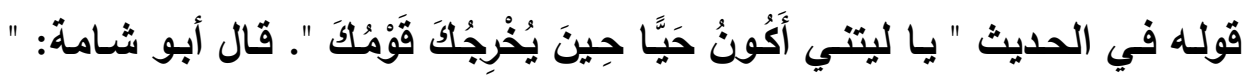

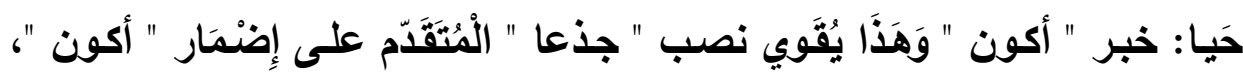

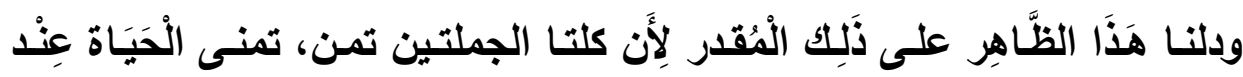

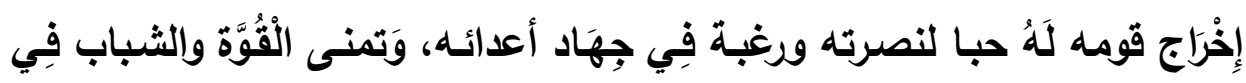

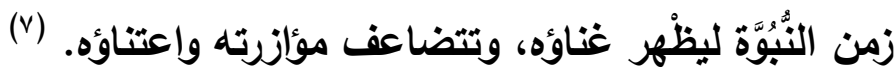

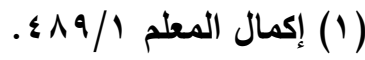

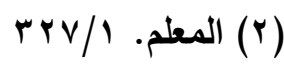

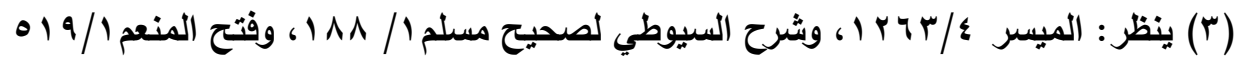

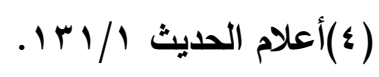

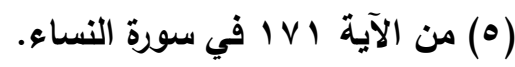

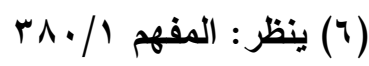

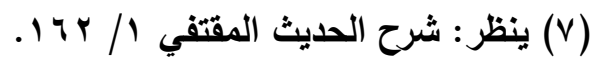


الثالث: أن تكون "ليت "أُعمِت عمل تمنّيثُ، فنصبت اسمين، كما أجاز

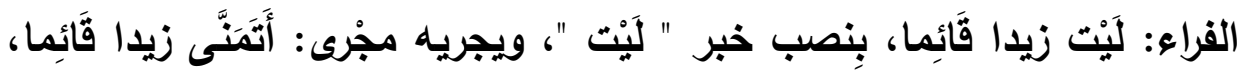

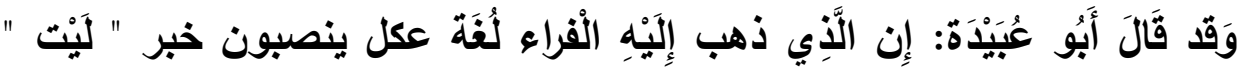

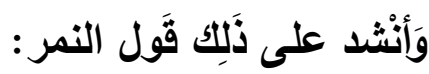

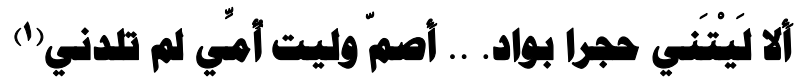

أها رواية ابن ماهان " جذع " بالرفع فلا اشكال فيها من جهة الإعراب، فهي

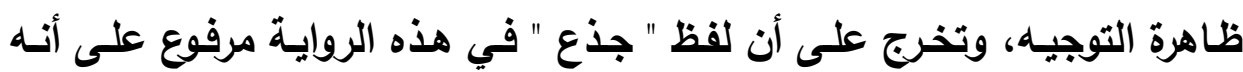

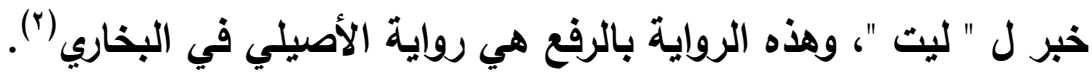

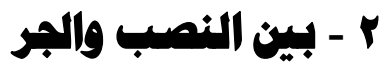

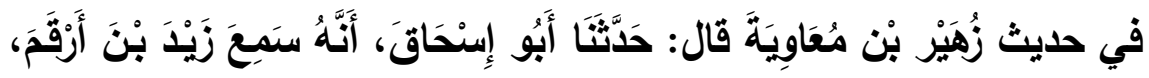

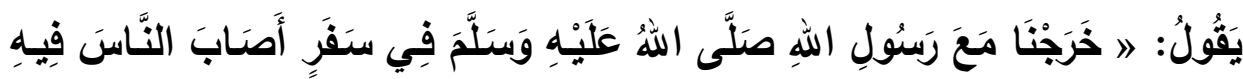

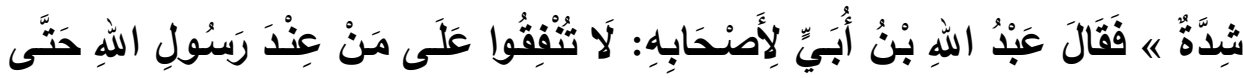

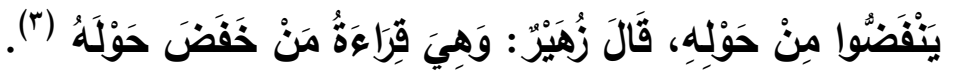

\section{الدراسة والتميل}

الحديث في سياق بيان صفات المنافقين وأحوالهم، وقولـهـ "( قَالَ زُهَيْرُ)

$$
\text { يعنى به زهير بن معاوية راوي الحديث عن أبي إسحاق. }
$$

والعبارة التي قالها زهير هي " وهى قراءة من خفض حولهله " ممـا يشكل تفسيره وييانه، وقد ضبطت هذه العبارة عن الوقشي من طريق ابن ماهان " مِن

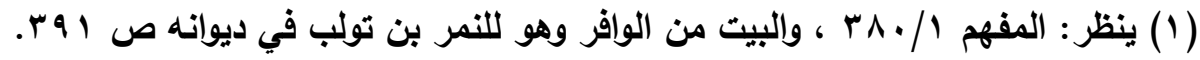

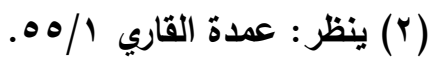

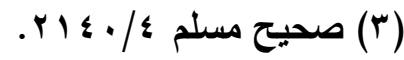




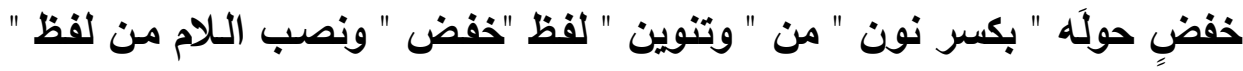

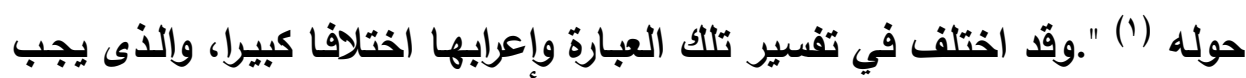
تقريره بداية عدة أمور:

أولا: أن هذه العبارة من قول زهير بن معاوية حكاية لقول عبد الله بن أبي

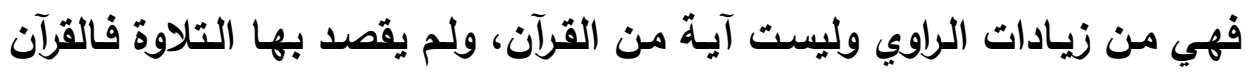

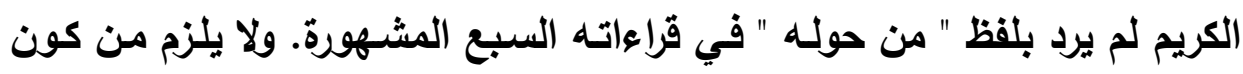

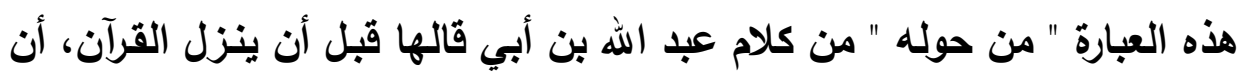

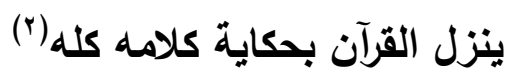
ثانيا: ذهب بعض الثراح إلى أن لفظ " من حوله " وقعت في قراءة ابن

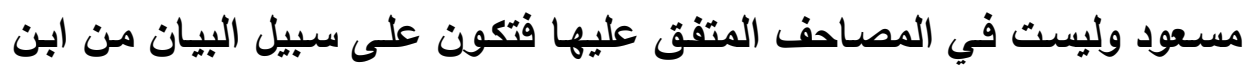
مسعود، وكثير من قراءاته جاءت على وجه التفسير (). ثالثا: ذهب بعض العلماء إلى أن "من حوله " موجود في قراءة عبد الله بن

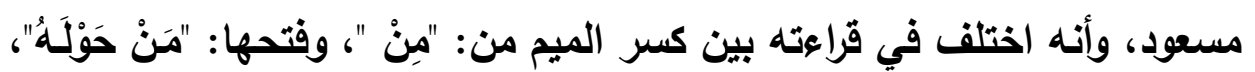

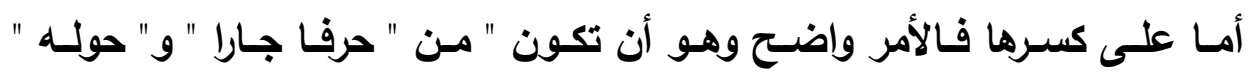

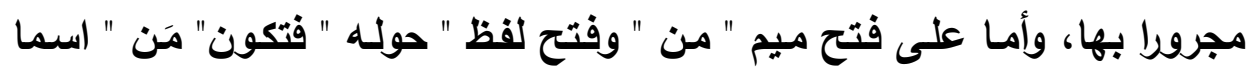

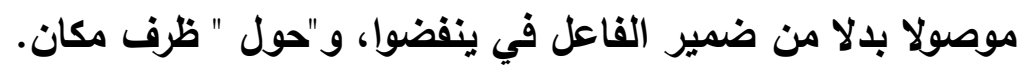

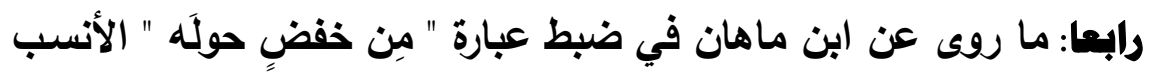

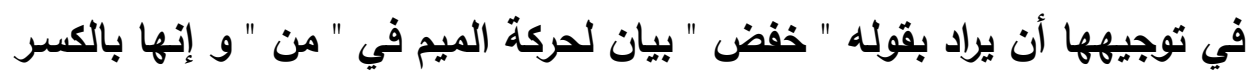

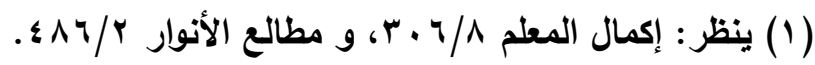

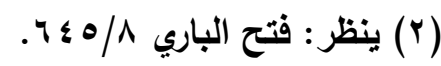

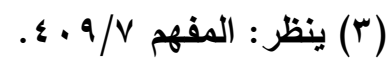


في قراءة عبد الله، ومما يقوي هذا التفسير أن هذه العبارة رويت بلفظ: "خَفَضَ

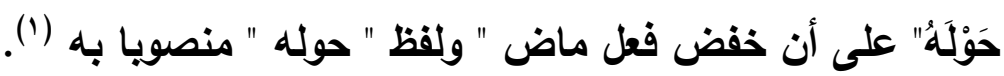

\section{ثانيا: تعاقب هروف المعاني}

\section{" الباء، ومن، وفي " (20)}

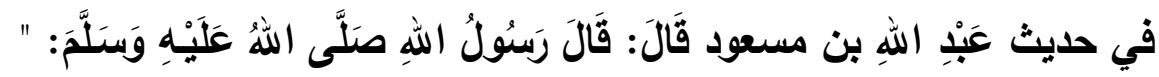

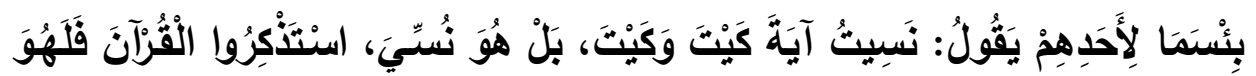

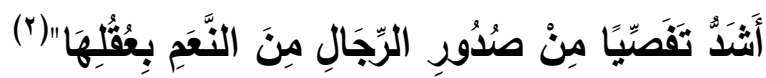

\section{الدراسة والتمليل}

العديث في سياق الأمر بتعهر القرآن، ومداومـة استظهاره وحفظه، وقولهه:

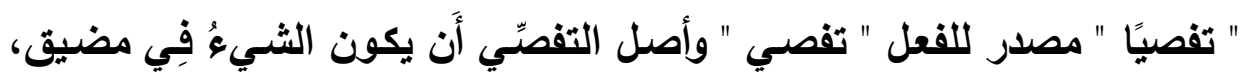

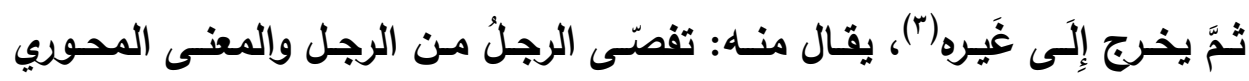

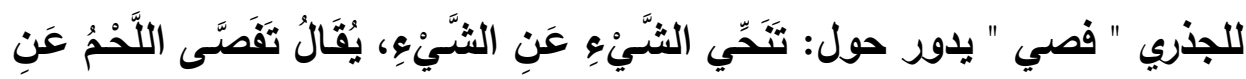

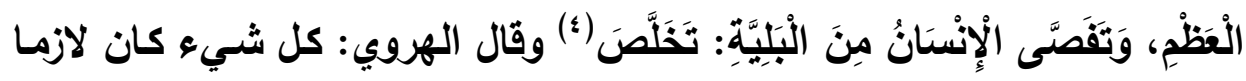

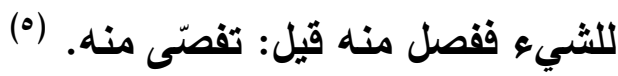

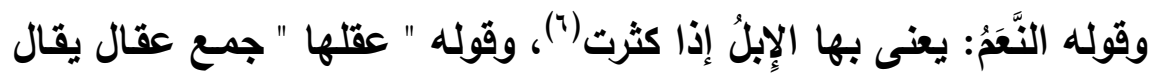

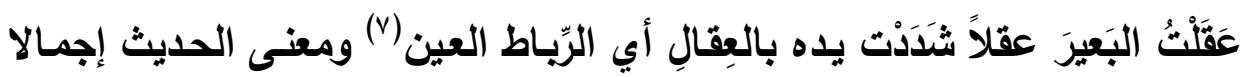

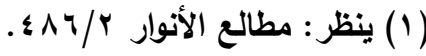

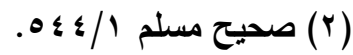

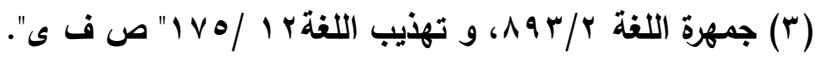

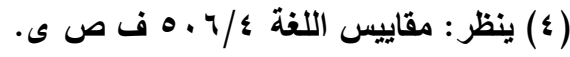

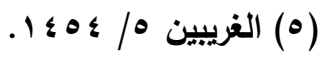

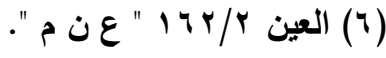

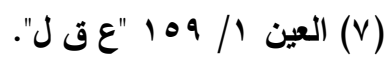


دائر على تشبيه من يتقلت منه بعض القرآن بالناقة التي انفلتت من عِقالها. (1)

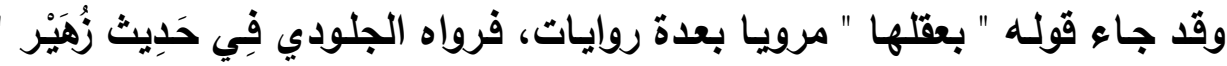
بعقلهـا " بالباء، وَرواه ابن ماهـان " مسن عقلهَا " بلفظ " مسن " كمـا روي " في

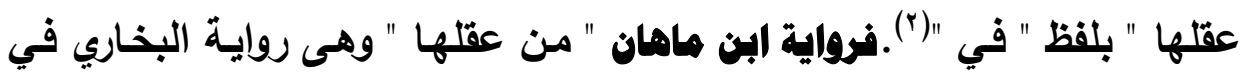

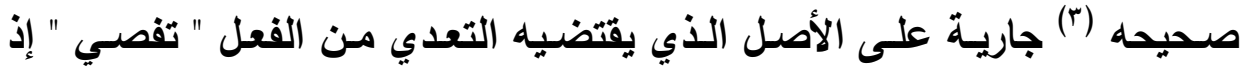

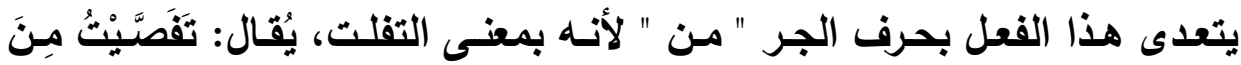

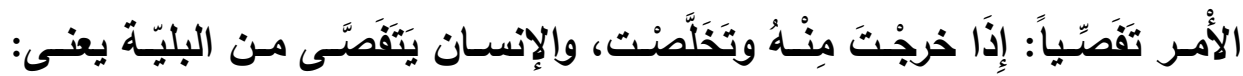
يتخلص. (؛) وأما هن رواه ” بعقها " بالباء فقيل في توجيهها أن الباء في هذه

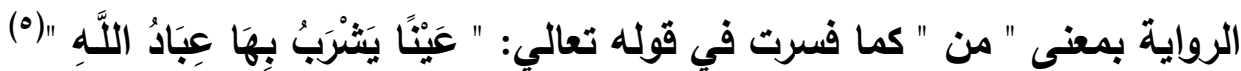
قال ابن قتيبة: " تقول العرب: شريت بمـاء كذا وكذا، أي من مـاء كذا. قال الله

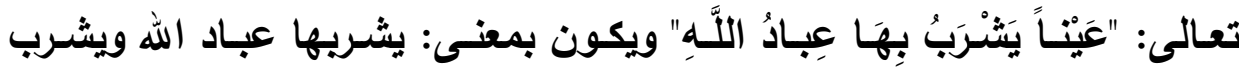
منها(") وأما رواية " في عقلها " بلفظ " في " فتحتمل الظرفية أي أشد تفصيًا من فن فئن تفصي النعم حالة كونها ملتبسةَ في عقلها. ومـن خـلال مـا تقدم يمكن القول بـأن روايـة ابـن ماهـان أولـي الروايـات بالاعتماد من الوجهة اللغوية لكونها على الأصل في تعدى الفعل تفصي بحرف

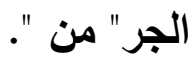

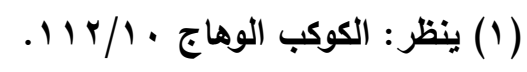

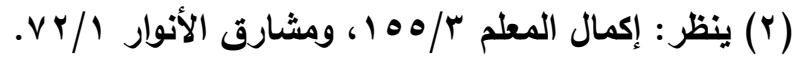

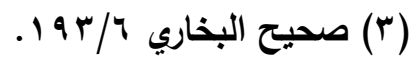

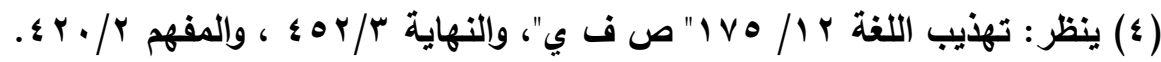

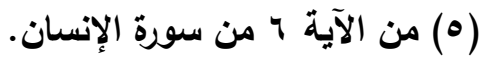

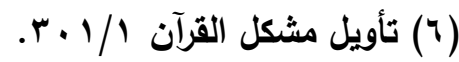




\section{ثالثا " من " بين الموصولية والجارة}

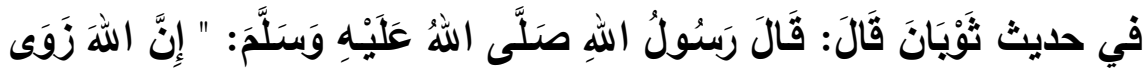

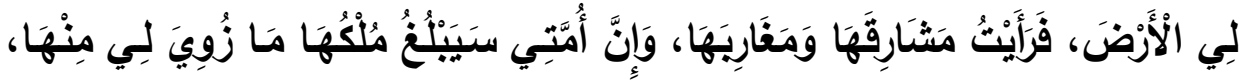

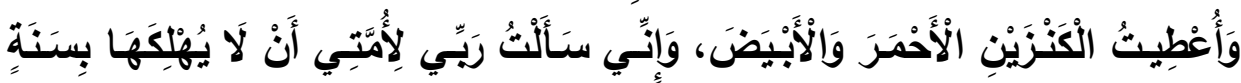

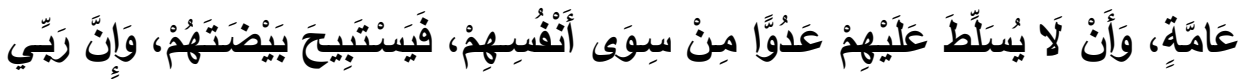

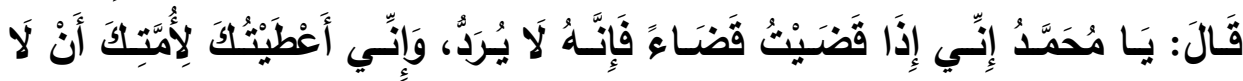

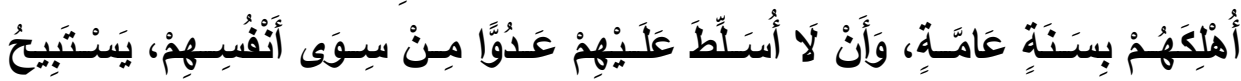

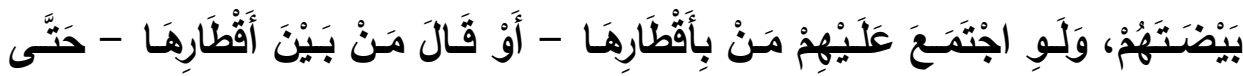

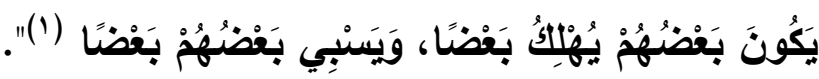

\section{الدراسة والتمليل}

الحديث أخرجه الأمسام مسلم في بـاب هـلاك هذه الأمسة بعضهم ببعض،

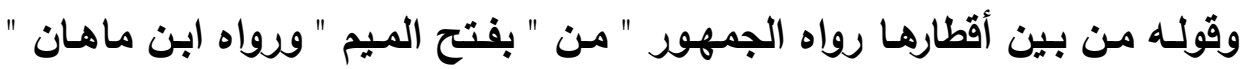

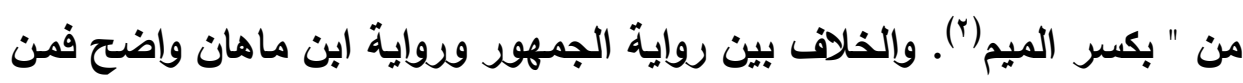

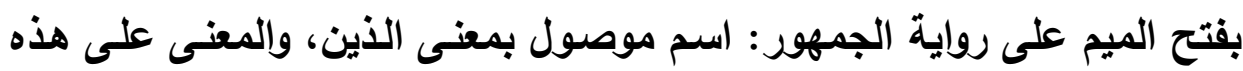

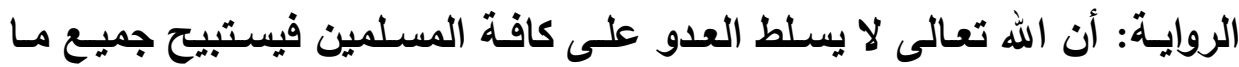
حازوه من البلاد والأرض، ولـو اجتمع عليهم كل النـاس الذين هم بين أقطار الأرض، يعنى ساكنيها فى جوانبها ونواحيها المختلفة (ז).

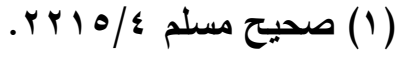

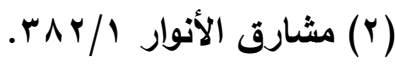

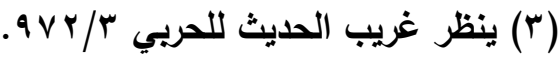


أما رواية ابن ماهان " فمن " بكسر الميم فيها، حرف جر لابتداء الغاية

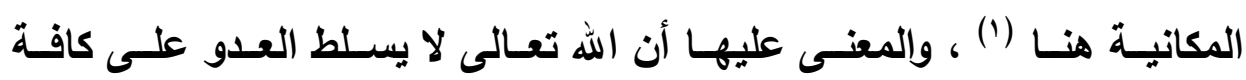

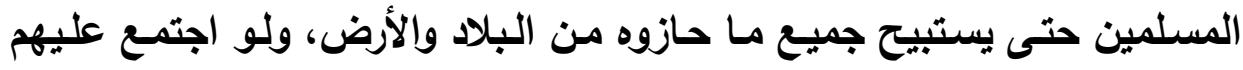
الأعداء ابتداء من كل مكان في جوانب الأرض ونواحيها.

والمعنى على الروايتين متقارب ويفيد لطف الله تعالي بهذه الأمسة بيركة

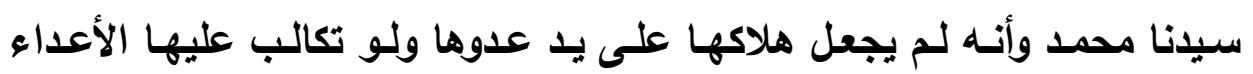
الذين يسكنون جوانب الأرض كافة.

\section{رابعا: التزكيب بين المذف والريادة}

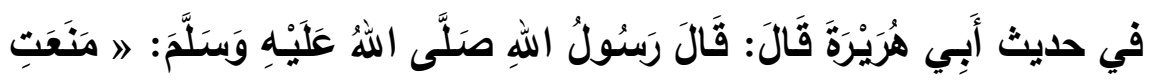

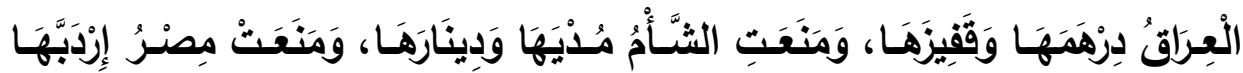

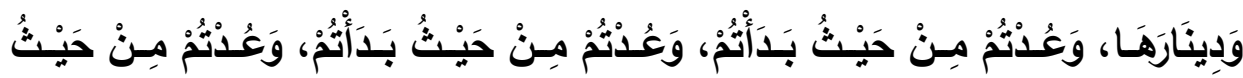

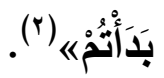

\section{الدراسة والتمليل}

العديث في باب لا تقوم السـاعة حتى يحسر الفرات عن جبل من ذهب،

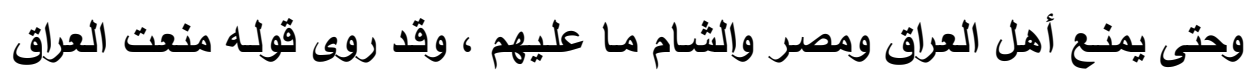

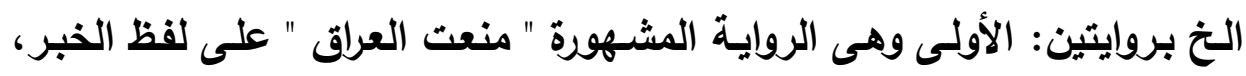

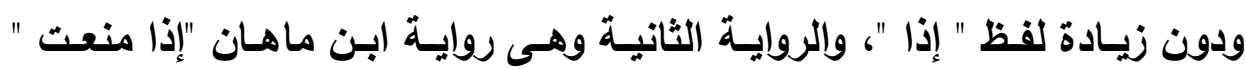

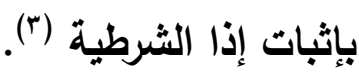

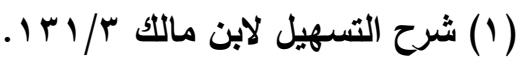

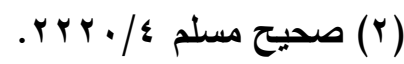

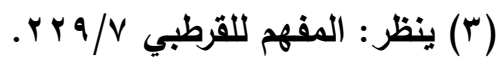


أهـا الروايسة الأولي: فخرجت على الخبر وأنـا إخبار منـه صلي الله عليه وسلم بما يقع في المستقبل من منع هذه البلدان المفتوحة من تأدية مـا عليها،

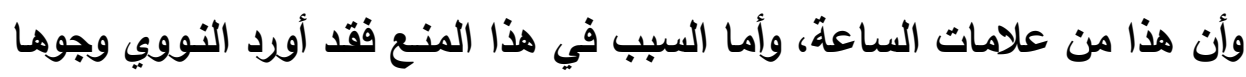

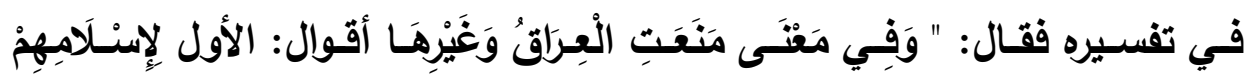

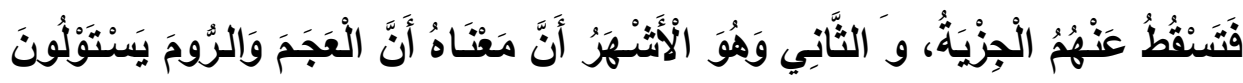

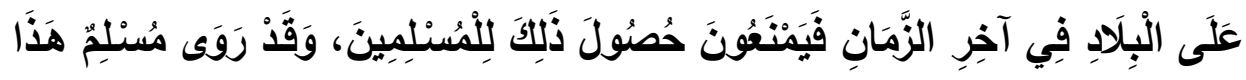

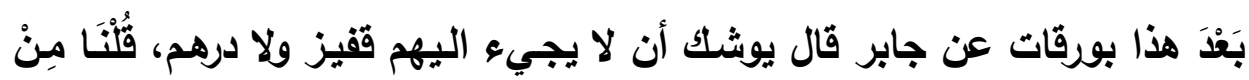

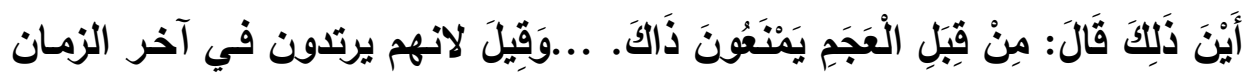

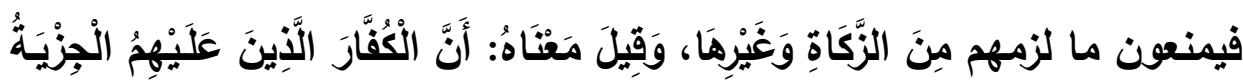

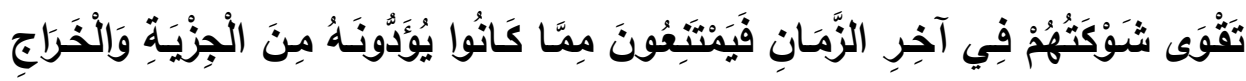

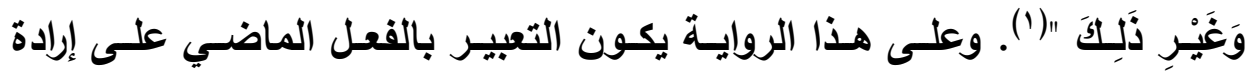

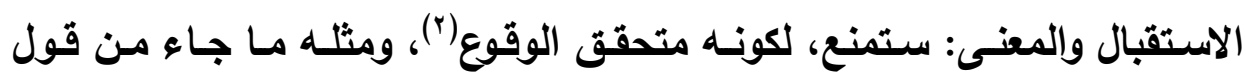

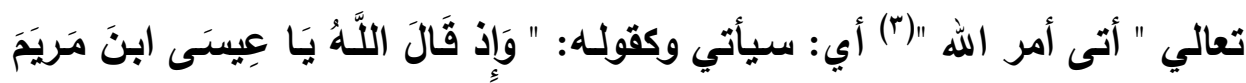

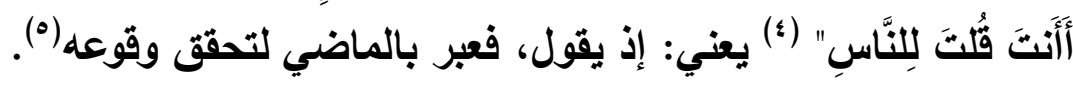

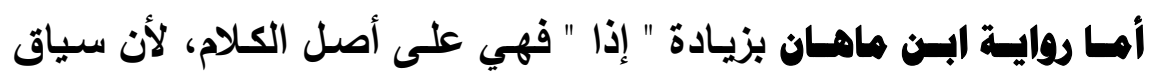

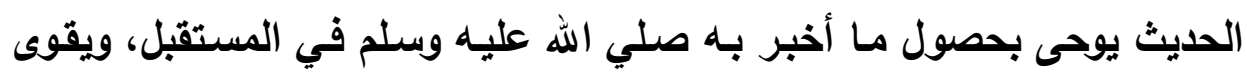

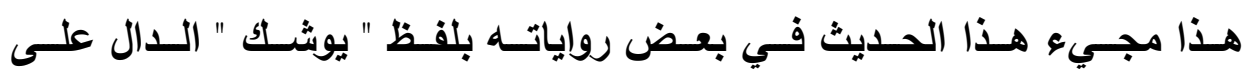

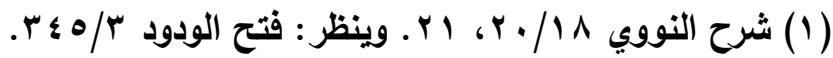

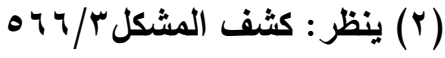

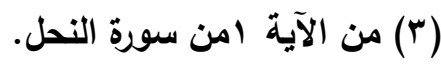

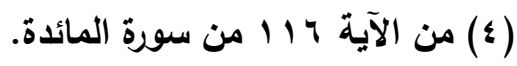

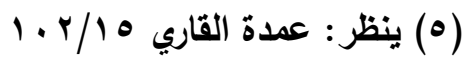


الاستقبال (1). فمجيء " إذا " في هذه الروايـة وهى ظرف لما يستقبل من الزمان

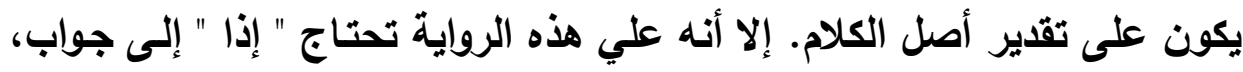
وقد اختلف في تقدير جوابها على وجهين: الأول: أن يكون جوابها قوله " وعدتم

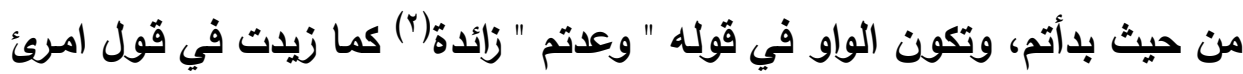

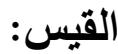

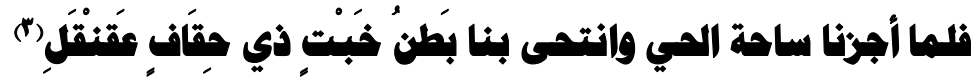

فالتقدير فيها أجزنـا سـاحة الحس. الثاني: أن يكون جواب " إذا " محذوفا

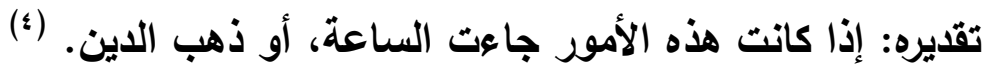

\section{خامسا: البمالة بين الإسمية والفملية}

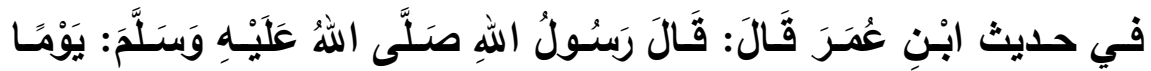

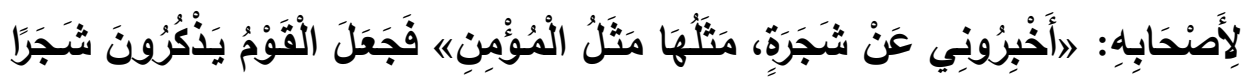

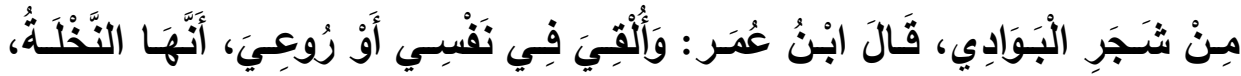

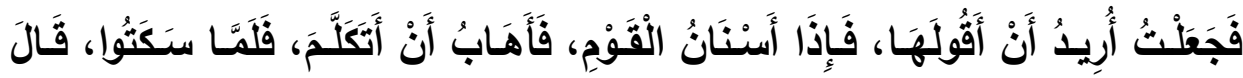

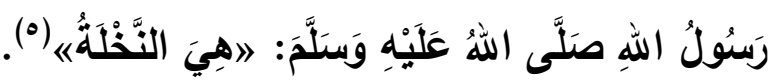

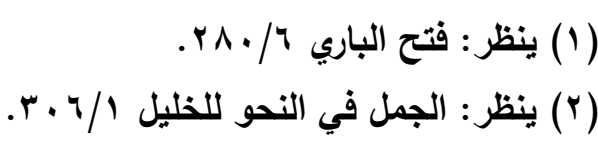

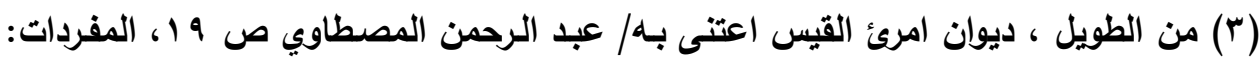

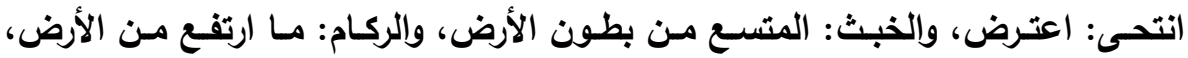

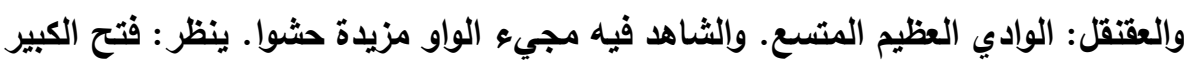

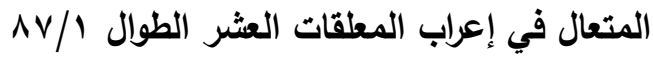

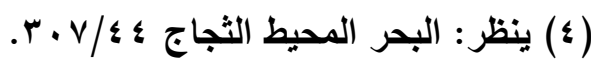

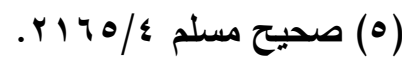




\section{الدراسة والتمليل}

قوله في الدديث " فإذا أسنان القوم " رواه الجلودي بلفظ " إذا " ورواه ابن

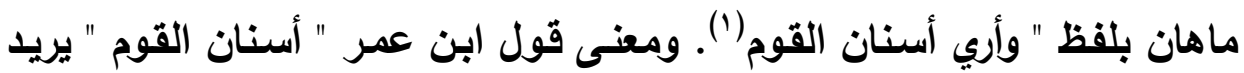

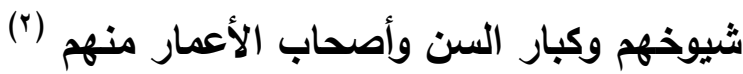

\section{وعلى رواية ” فإذا أسنان القوم " يكون التركيب مكونـا من إذا الفجائية،} والجملة الإسمية بعدها فلفظ أسنان مبتـأ وهو مضـاف إلى قولــه القوم، والخبر محذوف تقيره حاضرون أو موجودون.

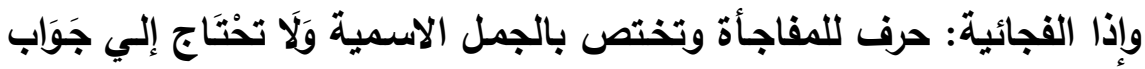

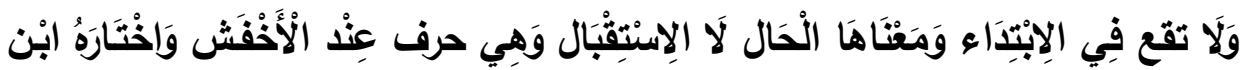

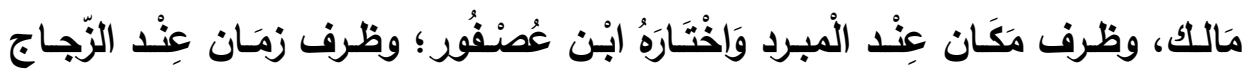

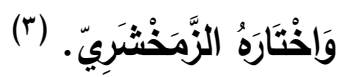

\section{أهما على رواية ابسن هاهـان " وأري أسنان القوم " فالجملة فعلية مصدرة} بفعل مضـارع والفاعل مستتر يعود على ابـن عمـر، ولفظ "أسـنان " مفعول بـهـ

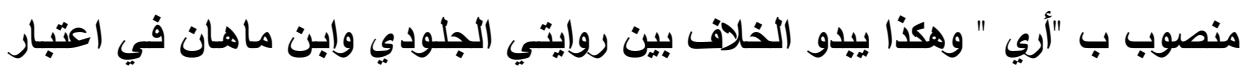

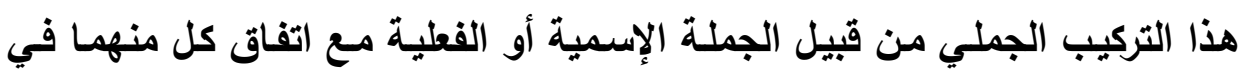

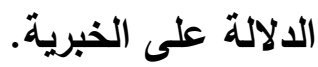

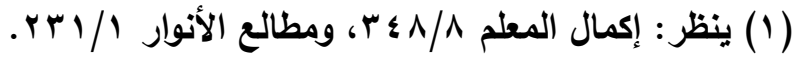

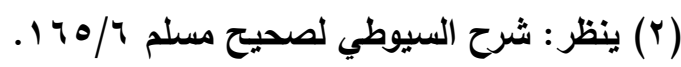

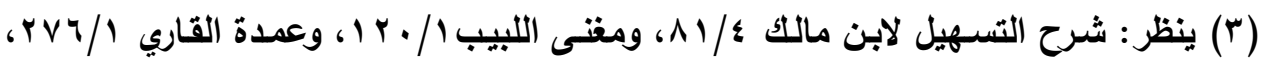

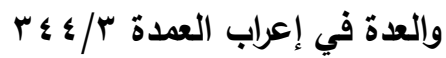




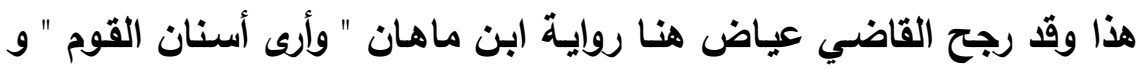

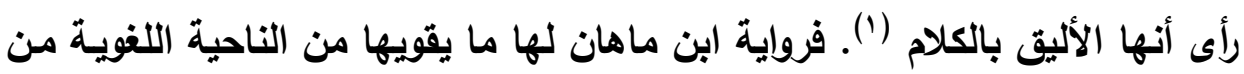

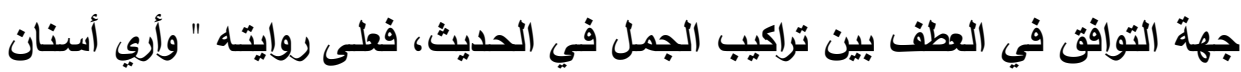

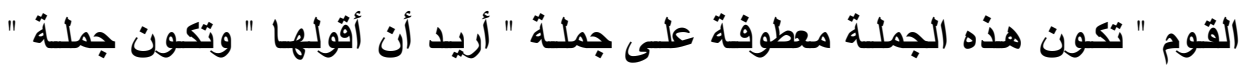

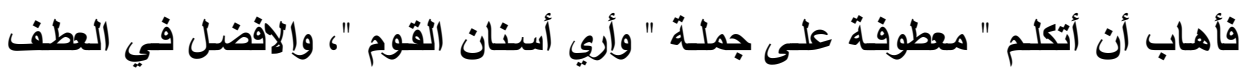

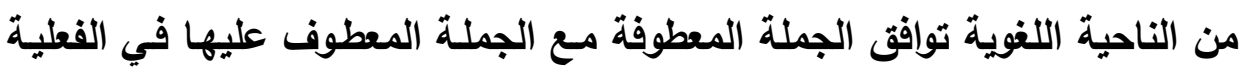

والاسمية ونحوهما، إذ التناسب في العطف أولى من التخالف(†ن).

\section{المبمث الرابع: المستوى الدلالي}

تمهيسـد: يعد التحليل على المستوى الدلالي أصسب مستويات التحليل

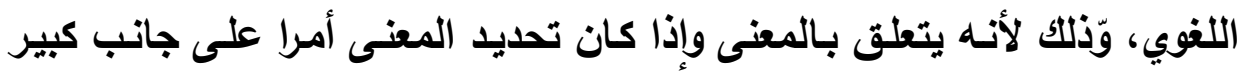

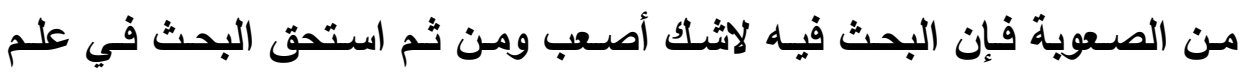

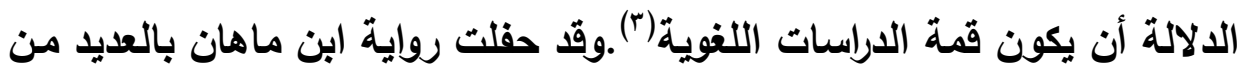
المظاهر المتعلقة بالناحية الدلالية للألفاظ

\section{أولا: الترادف}

تعد ظاهرة تعدد الألفاظ للمعنى الواحد، أو ما يطلق عليه في اللغة الترادف

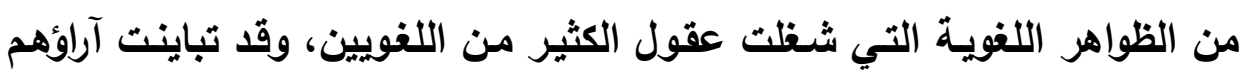

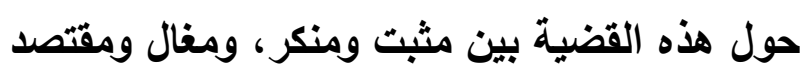
والذي تطمئن إليه النفس هنا هو مـا ذهب إليه أكثر اللغويين المحدثين

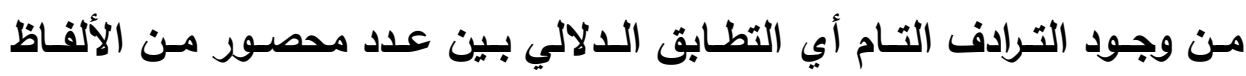

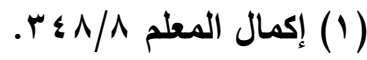

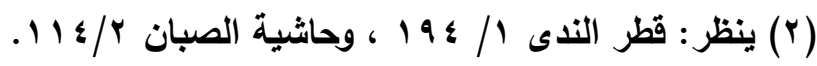

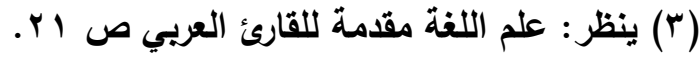


اللغوية، أما الترادف بمعنى اثترراك اللفظتين في المعنى الدلالي العام ثم انفراد

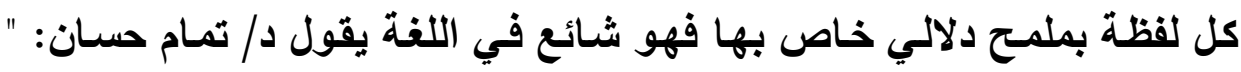

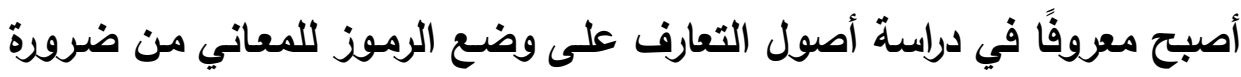

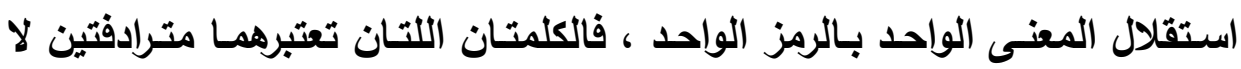

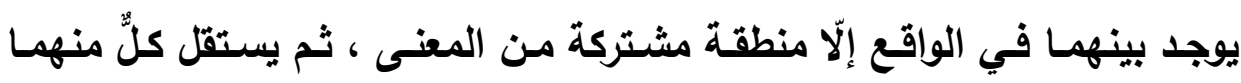

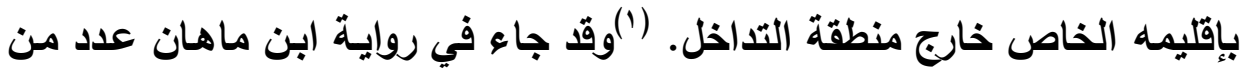
الألفاظ يمكن إدراجها تحت ظاهرة الألفاظ المترادفة:

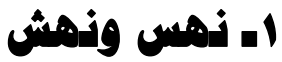

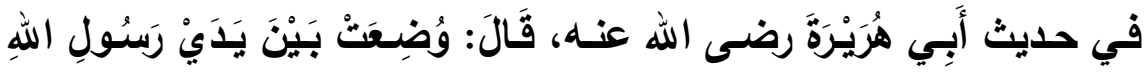

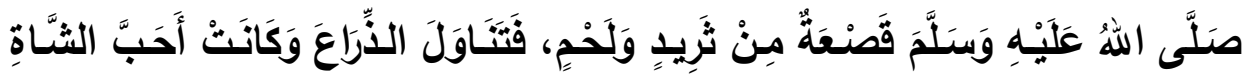

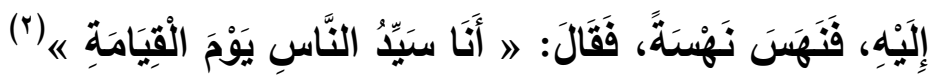

\section{الدراسة والتمليل}

قولـه " فنهس نهسـة " رواه أكثر الرواة بالسين المهملة، وجاء في راويـة

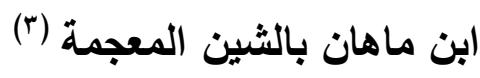

وقا اختلف اللغويون وتبعهم شراح الحديث في تفسير الروايتين، وانقسموا إزاء ذلك إلى فريقين:

الفريـق الأول: ذهب إلى القول بترادفهما وأنهما بمعنى واحد وهو: الأخذ من الثشاة والأكل منها على وجه السرعة، قال ابن فارس في المقاييس وَتَهَسَ

(1) اللغة العربية معناها ومبناها ص و جr ، و وينظر : اللغة وعلم اللغة لجان ليونز ترجمة:

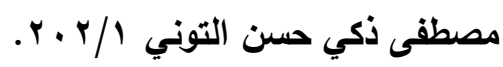

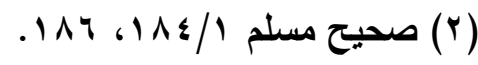

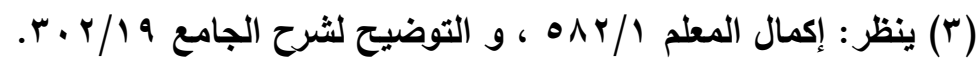




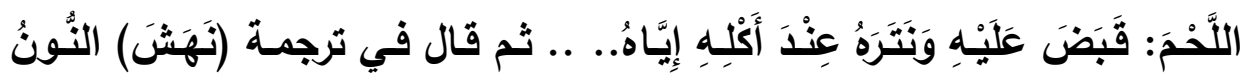

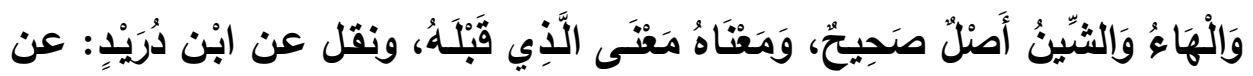

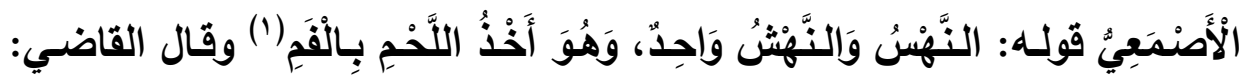

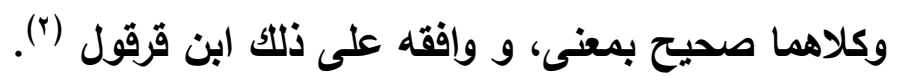

الفريق الثاني: وذهب إلى التفرقة بين اللفظتين في المعنى، من جهة أن

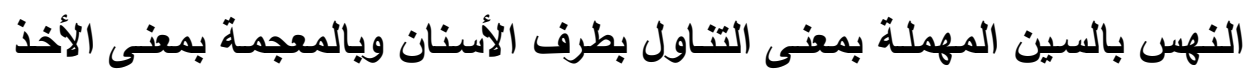

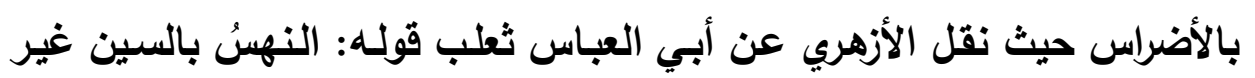

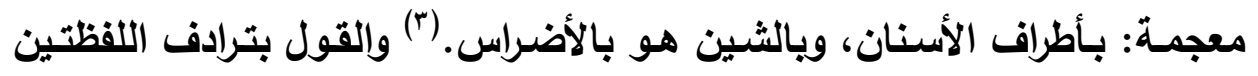

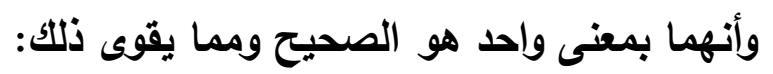

الأول: ذهـاب أكثر اللغويين وعلى رأسـهم الخليل إلى عدم التفرقة بـين

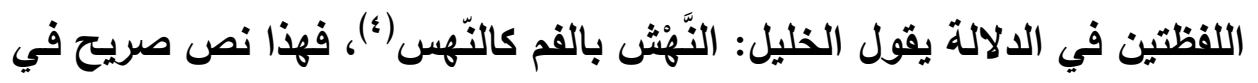

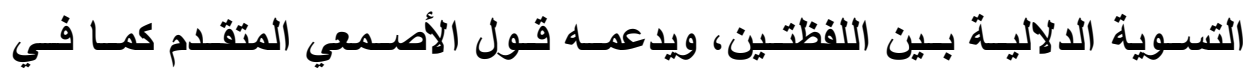
المقاييس.

الثاني: مجيء اللفظتين" نهش ونهس " بالسين المهملة والثشين المعجمة

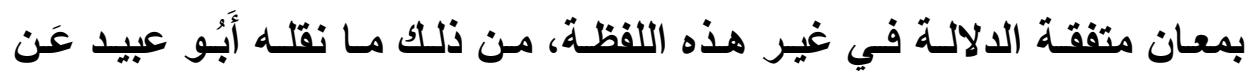

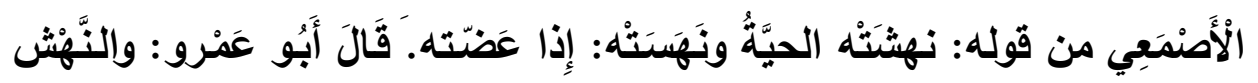

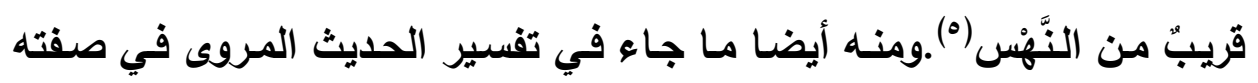

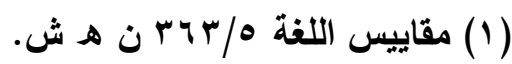

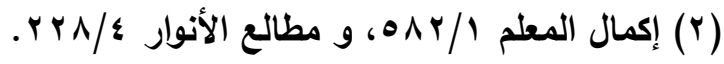

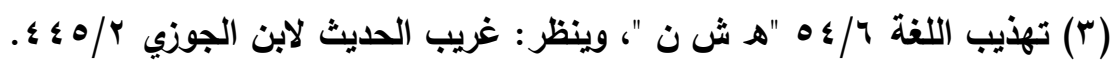

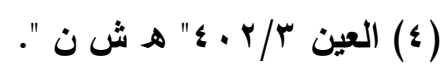

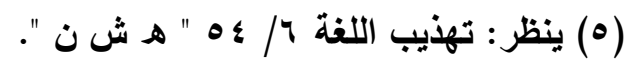


عليه السلام " أنه كان منهوس الْقَدَمَنِّ " فقد نقل عن ابْن الْأَعَرَّبي في تفسيره

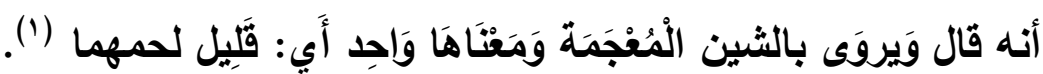

الثالث: تصريح بعض اللغويين كما في اللسان بأن صوت الثين يأتي لغة

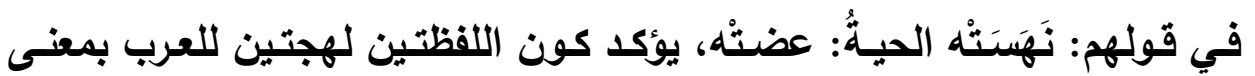
واحد

الرابع: أن سياق الحديث لا يظهر منه التفرقة بين اللفظتين في الدلالة

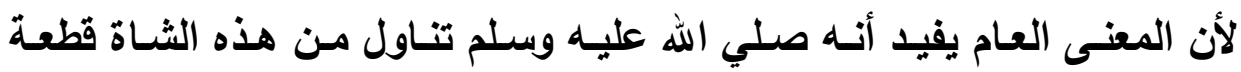
ليأكلها.

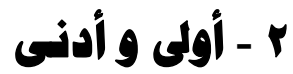

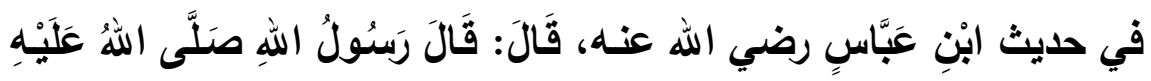

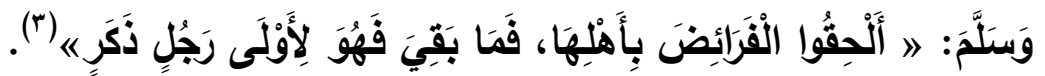

\section{الدراسة والتمليل}

الحديث في سياق بيان كيفية توزيع الميراث، وأنها يجب البدء بأصحاب

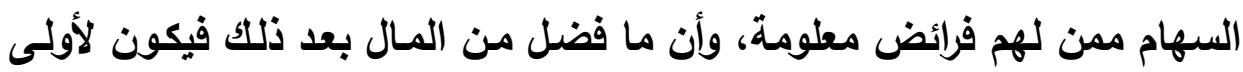
رجل ذكر من العصبة يعنى أقريهم إلى الميت.

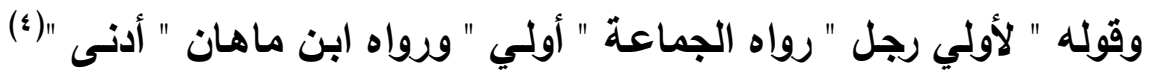

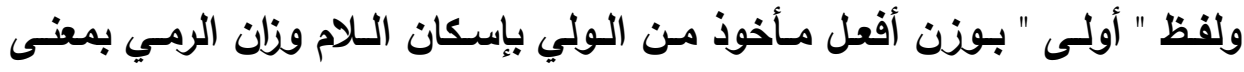

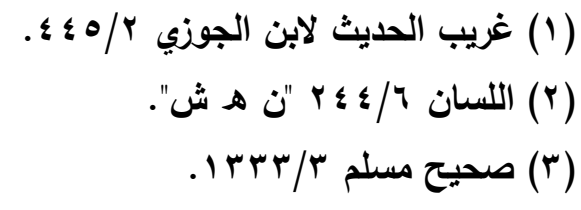

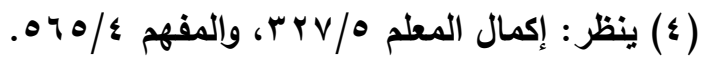


القرب، قال الجوهري: " التولَيُ: القربُ والدنوُ. يقال: تباعد بعد ولى. و كل ممـا

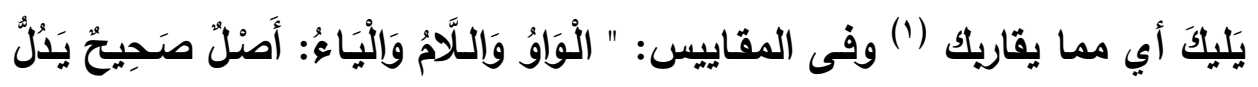

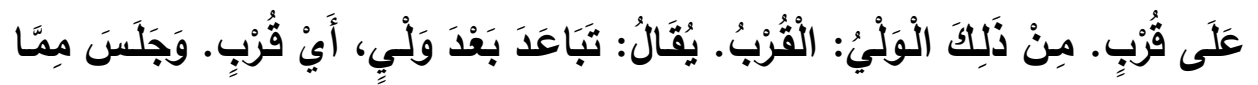

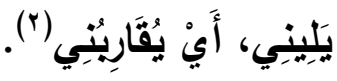

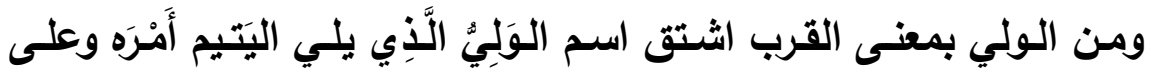

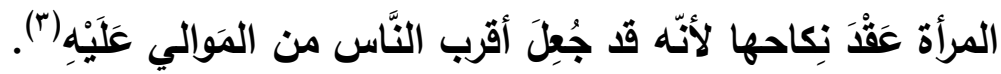

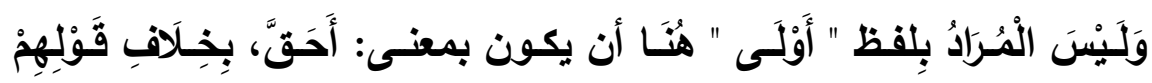

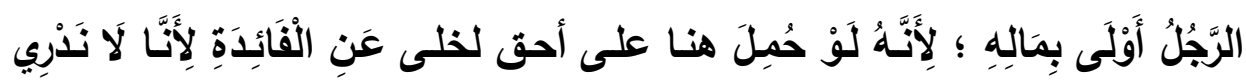

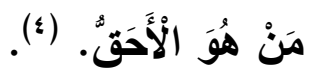

أها لنظة ” أدنى" وهى رواية ابن ماهان فهي أفعل من الانو بمعنى القرب،

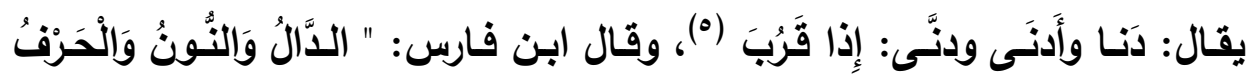

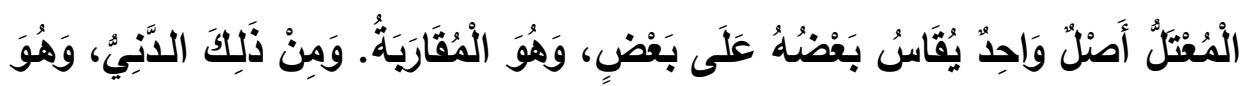

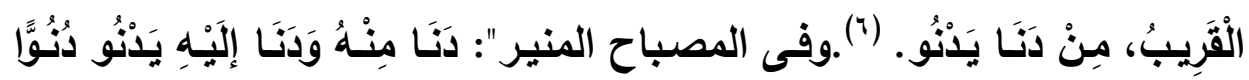

قَرَبَبَ (v)

ومن خلال مطالعة أقوال اللغويين للفظتين الواردتين هنـا نستطيع القول

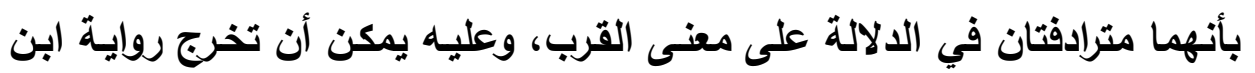

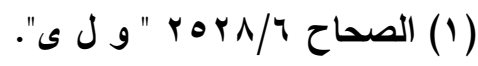

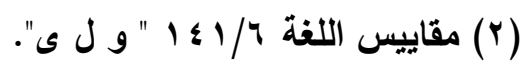

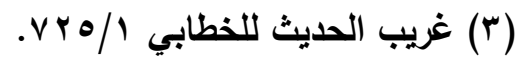

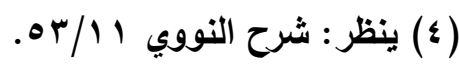

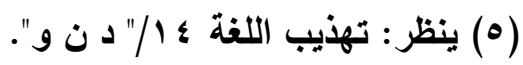

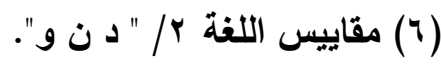

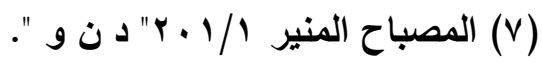


ماهان " أدنى " على أنها تفسير لرواية الجمهور ، وهى الأقرب في الدلالة على المقصود.

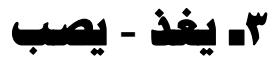

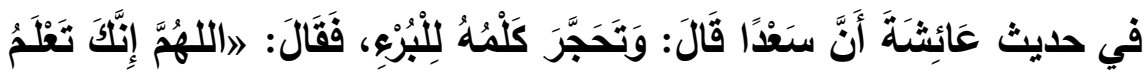

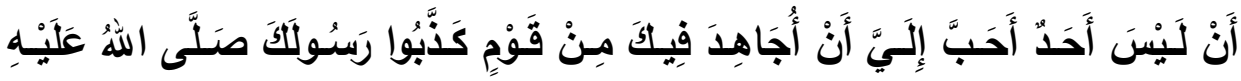

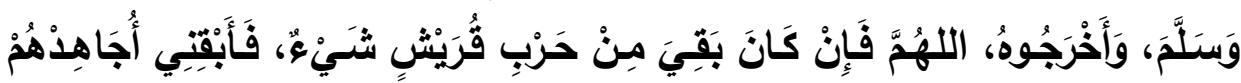

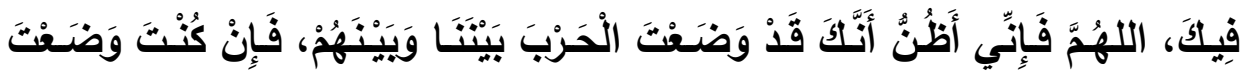

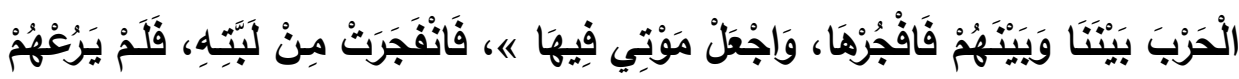

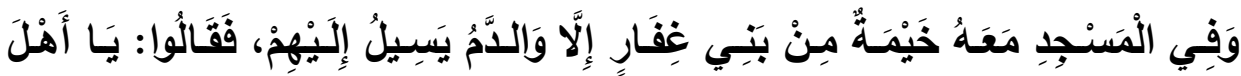

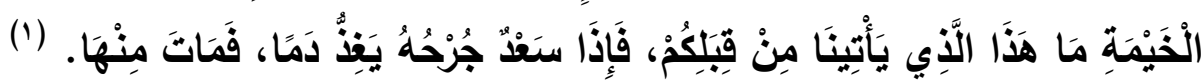

\section{الدراسة والتمليل}

قوله " فإذا سعد جرحه يغذ دما "هكذا روى قوله " يغذ " بالغين والذال لدى

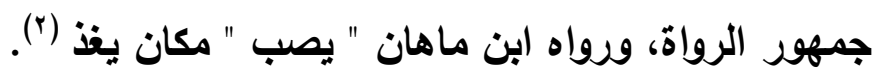

فأمسا قولهـ " يغذ " فقد روى بكسر الغين وضم الذال المشددة، ويإسكانها

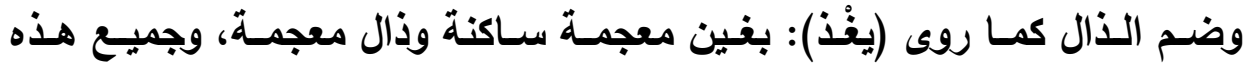

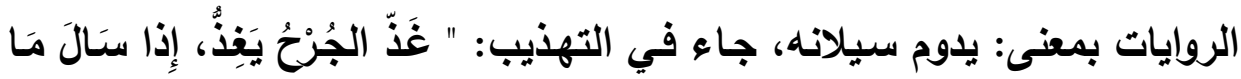

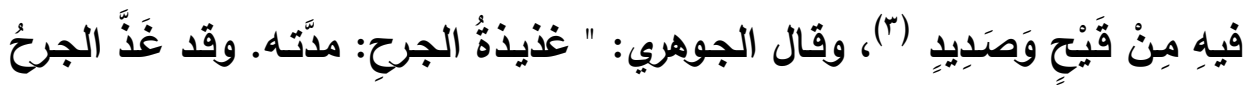

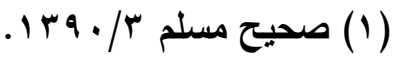

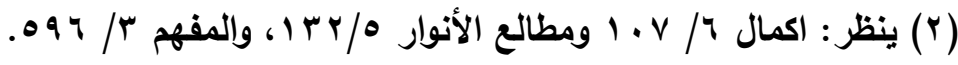

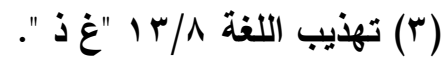




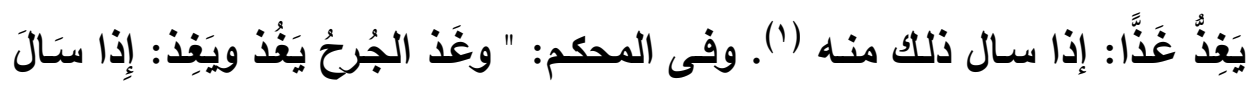

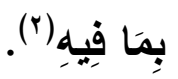

وأها رواية ابن ماهان " يصب " فهي فعل مضارع من الصب، وهو صَبُّك

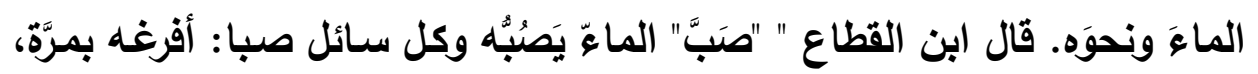

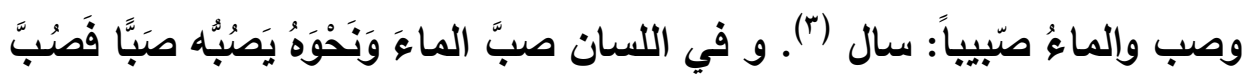

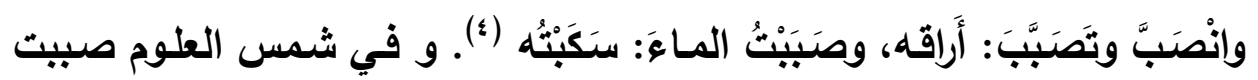

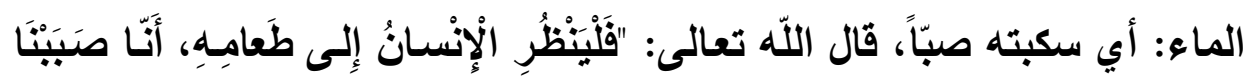

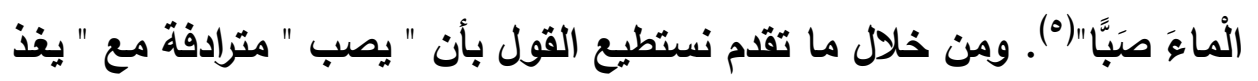

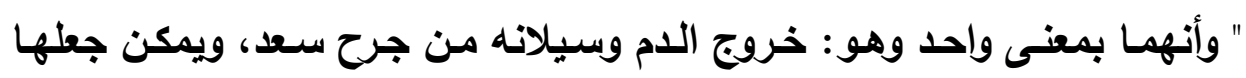

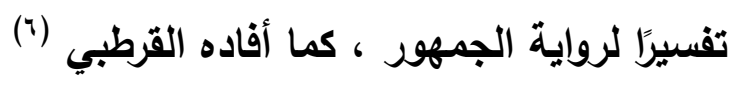

$$
\text { - } 1
$$

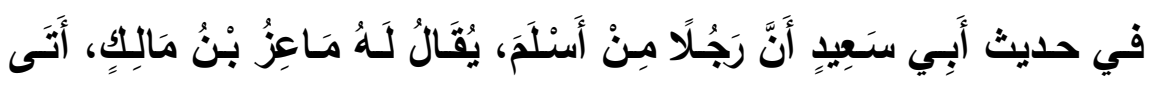

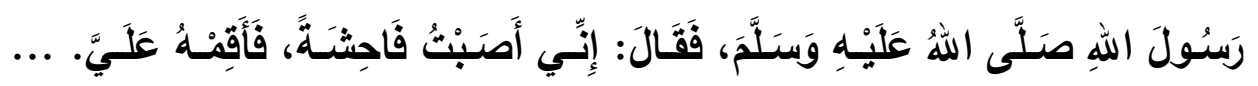

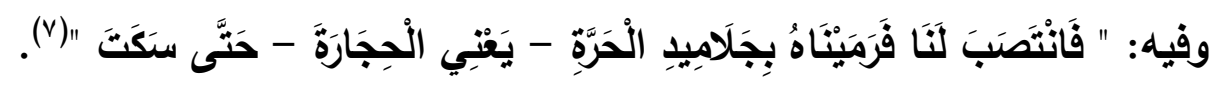

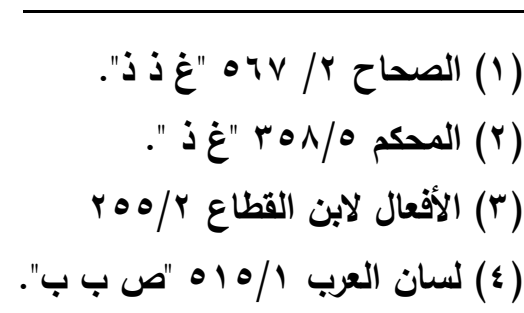

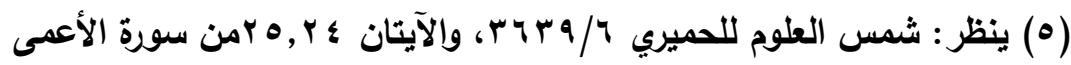

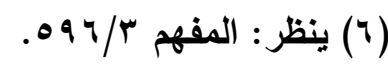

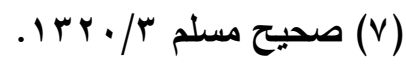




\section{الدراسة والتمليل}

وقوله: " حتى سكت " رواه كافة الرواة عن مسلم " سكت " بالتاء، ورواه

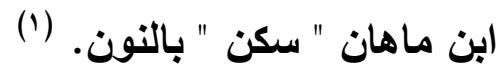

فرواية الجمهور وهى الرواية الأعرف والأثشهر، خرجت على أن سكت فيها

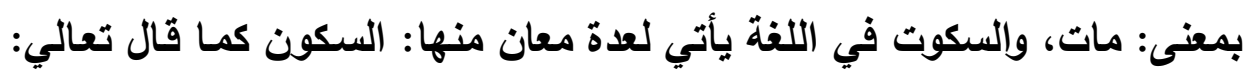

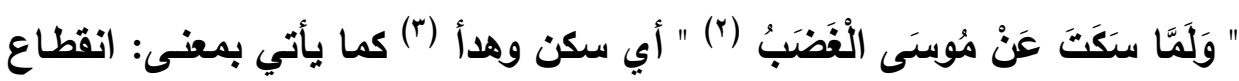

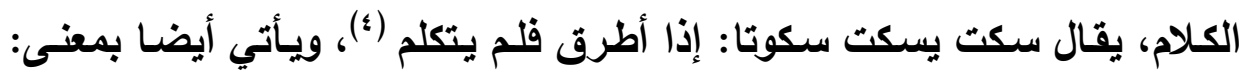

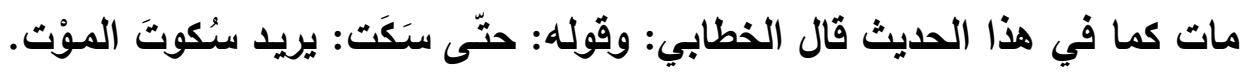

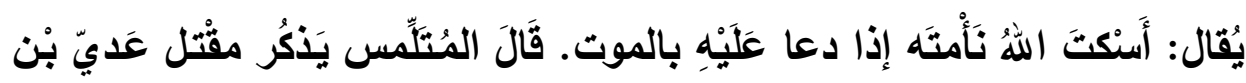

زَيْدُ

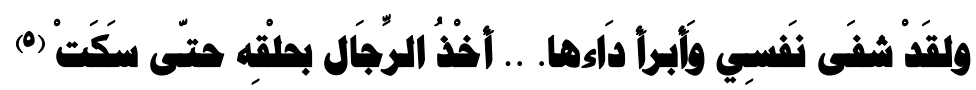

ومن خلال ما تقدم نستطيع أن نستثف المغنى المحوري للجذر اللغوي "

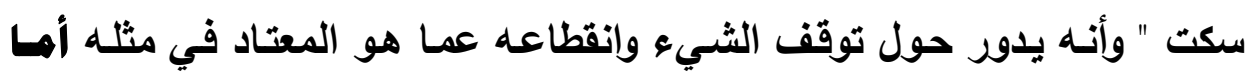

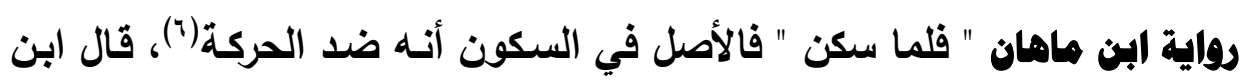

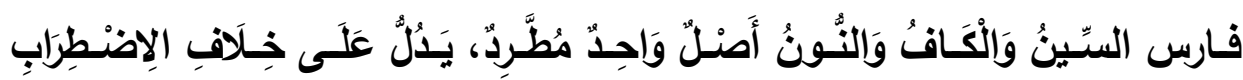

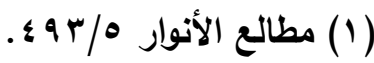

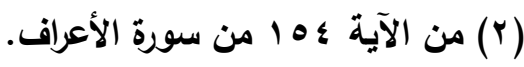

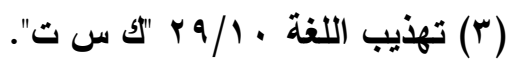

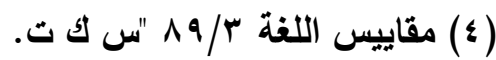

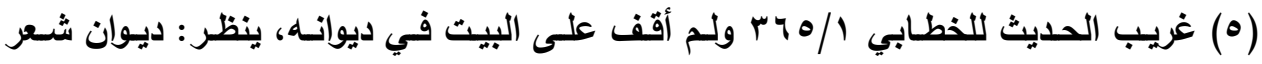

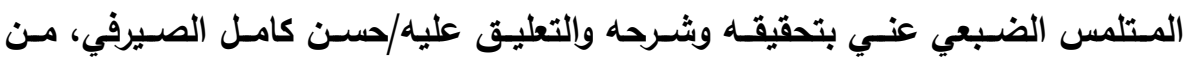

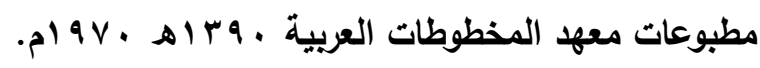

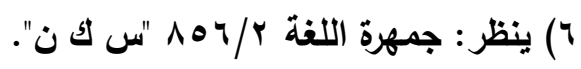


وَالْحَرَكَةِة. (') ويمكن حمل السكون هنـا على معنى الموت بجامع عدم التحرك. ومن هذا الوجه يمكن اعتبار الترادف بين لفظتي سكت وسكن بجامع الاشتراك في الدلالة على الانقطاع عن الحركة بالموت. ولذا قال القاضي عياض: "ورواه

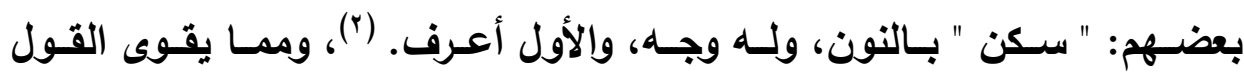
بترادف سكت وسكن في الالالة على الموت أنهما جاءت بمعنى واحد في آية: "

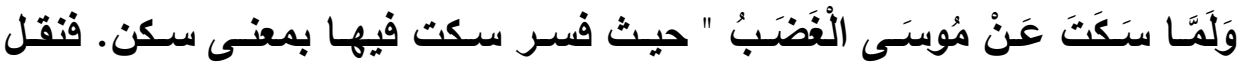

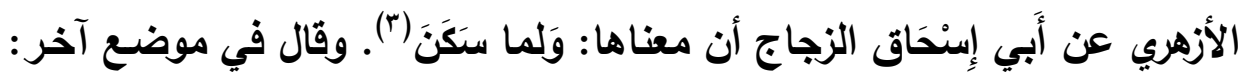

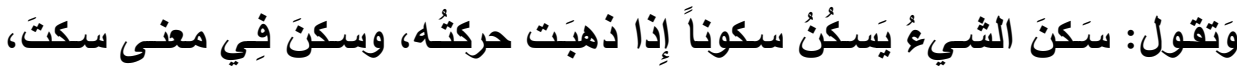

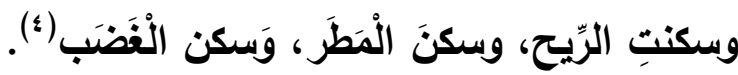

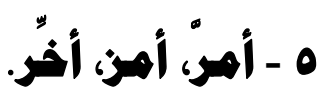

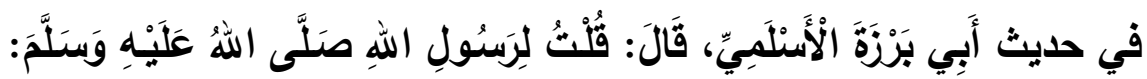

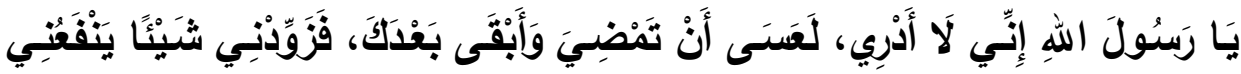

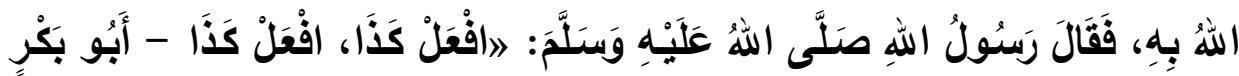

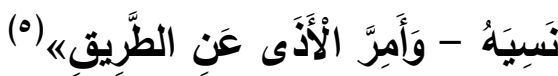

(1) مقاييس اللغة / / 1 "س ك ك ن.

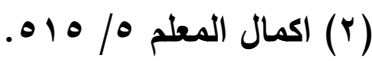

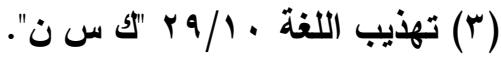

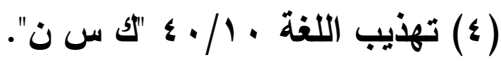

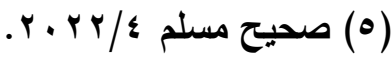




\section{الدراسة والتمليل}

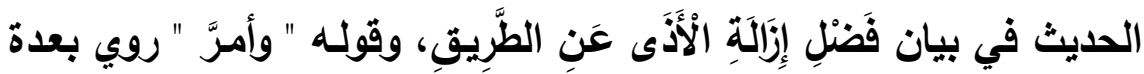

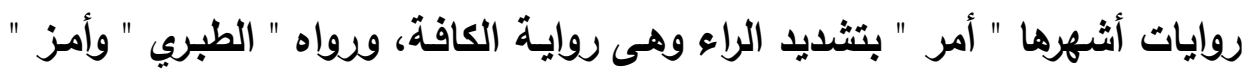

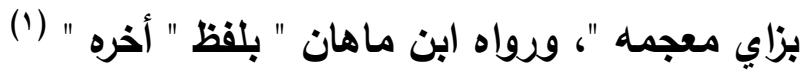

فأها الرواية المشهورة " أمر " مشددة الراء فهي أمر من الإمرار ومعناها

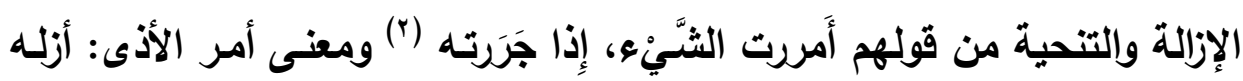

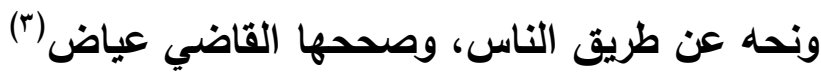

وأما رواية " أمز " بقطع الهمزة وكسر الميم وسكون الزاي فهي فعل أمر من الفعل " ماز" الذى يدور معناه حول التميز والفصل والعزل، جاء في العين:

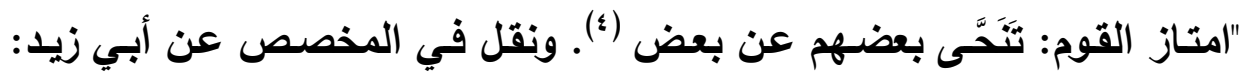

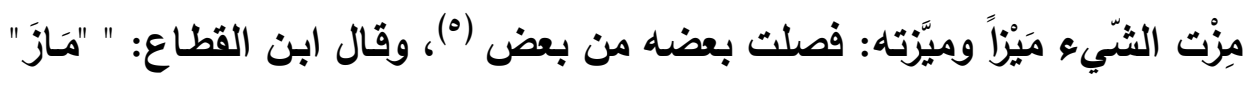

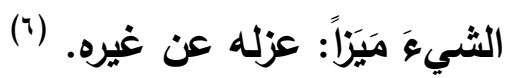

\section{وأها رواية ابن هاهان " أخر " بقطع الهمزة، وتثثديد الخاء المكسورة، فهي}

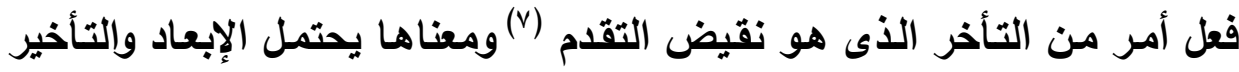

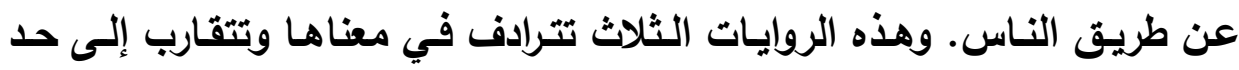

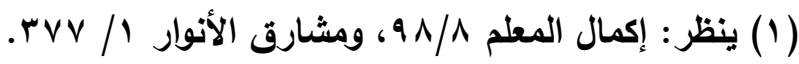

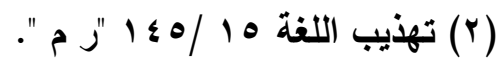

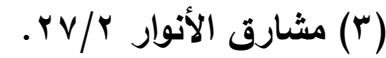

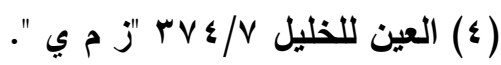

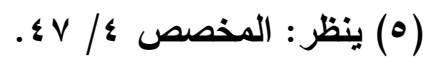

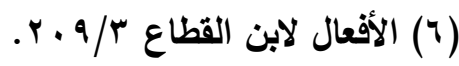

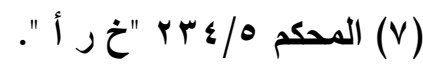


الاتحساد في المعنى حتى قـال القرطبي: " وكتّهـا بمعنى واحـد (1)، ويفهم مـن

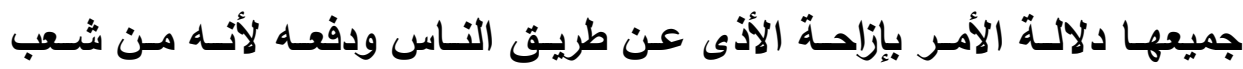
الإليمان.

\section{1. أتلى - أجلى - انجلى}

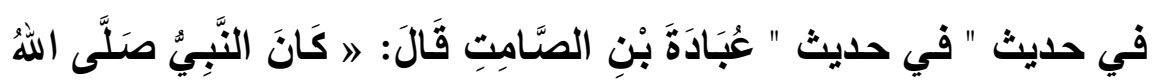

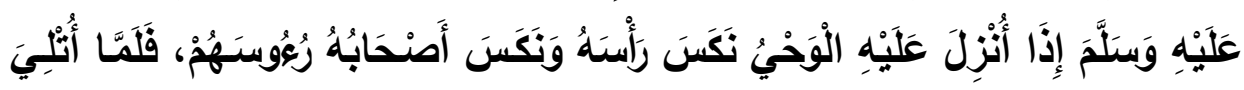

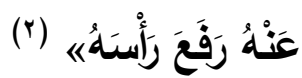

\section{الدراسة والتصليل}

الحديث في سياق بيان ما يكون من هيئته صلي الله عليه وسلم وهيئة

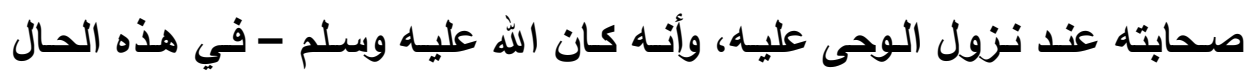

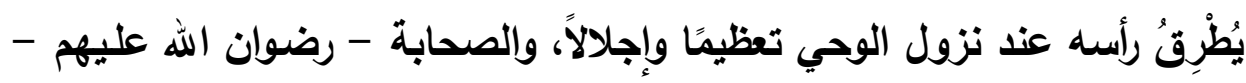

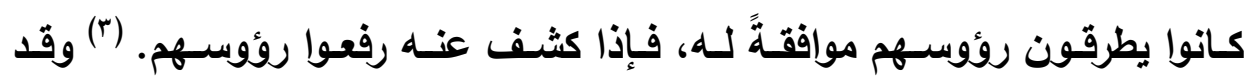

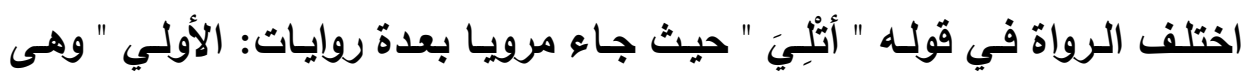

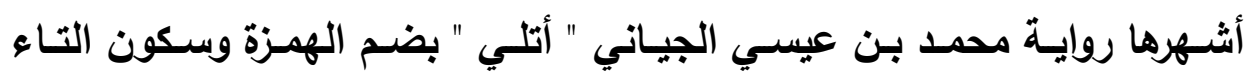

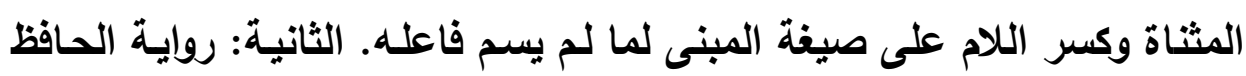

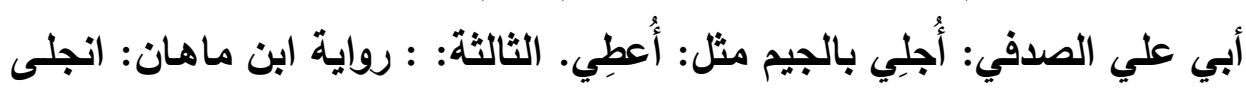

بالنون (؛) أبي علي الصنا

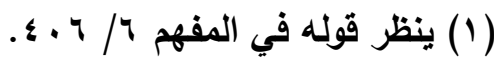

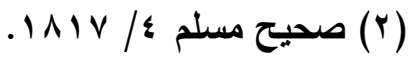

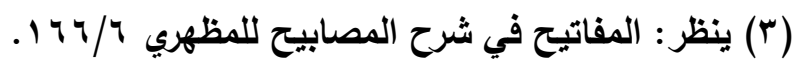

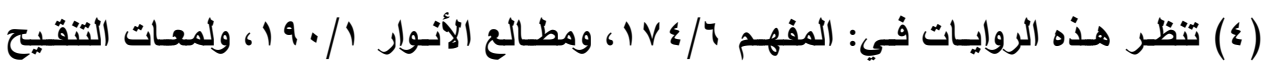

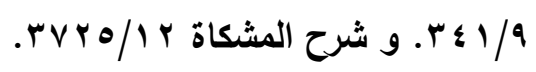




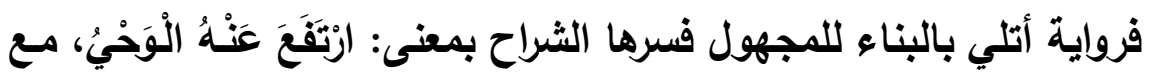
اختلافهم في اشتقاقها، فمن قائل أنها من الثلاثي: تلوته بمعنى: تركته كما جاء

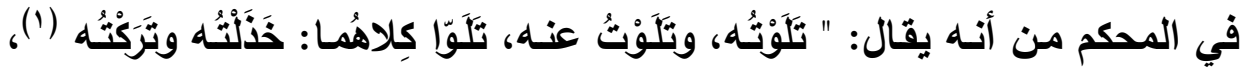

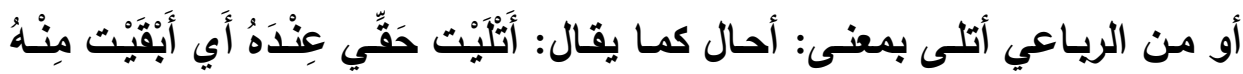

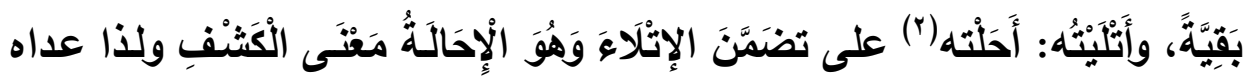

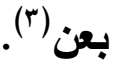

أما روايتا أجلي وانجلى فهما مأخوذتـان من الجلاء وهو: الإزالة والإذهاب

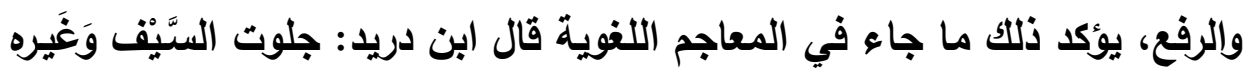

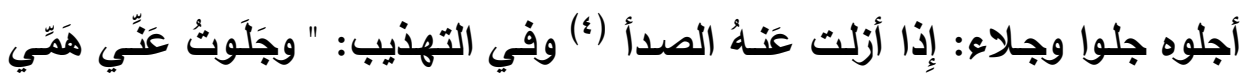

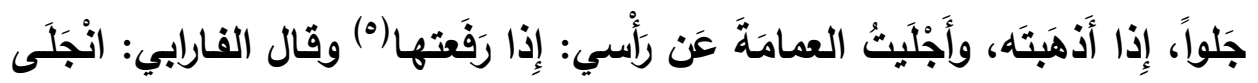

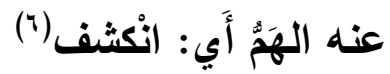

ويبقى الفرق بين روايتي " أجلي وانجلى "مرجعه إلى بناء روايـة الصدفي

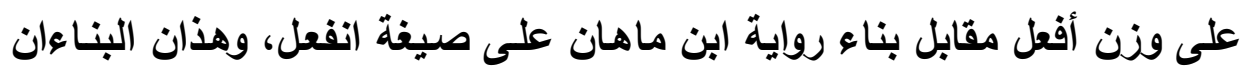

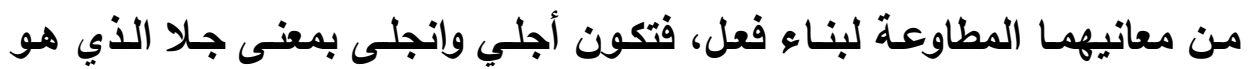
بمعنى الإزالة والرفع والكثف (v).

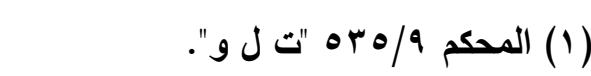

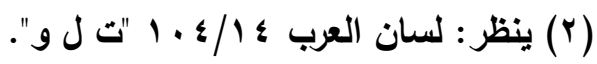

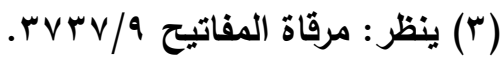

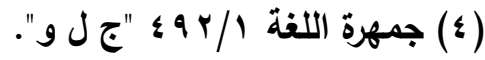

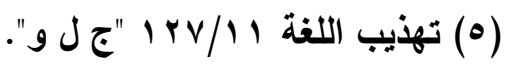

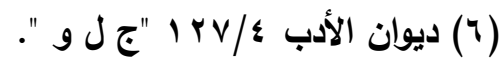

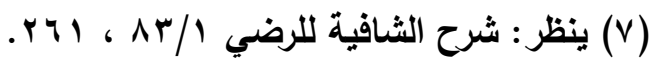


ويالتأمل نجد ان هذه الروايات على تعددها تثقارب في معناها الدلالي وهو

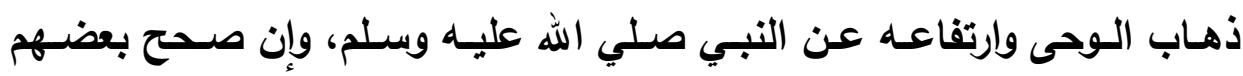

روايتي أجلي وانجلى (')

\section{ثانيا: الفروق الاغوية}

تنبع قضية الفروق اللغوية من الاختلاف الواقع بين مذهبين لغويين فى

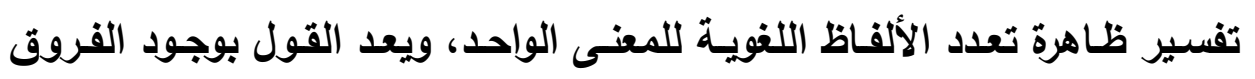
مذهبا مقابلا للقائلين بوقوع الترادف التام بين الألفاظ اللغوية. وإذا كان الأصل في اللغة بأن يوضع اللفظ الواحد لمعنى واحد يدل عليه (ץ) فإن تعدد الألفاظ الدالة على معنى واحد موجود في لغتنا و لا يمكن إنكاره.

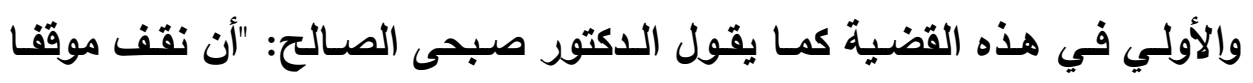

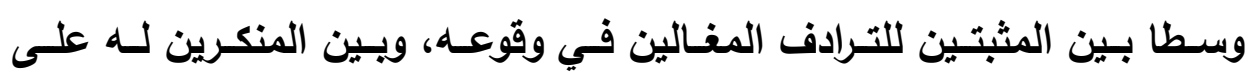

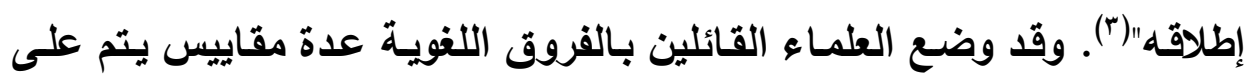

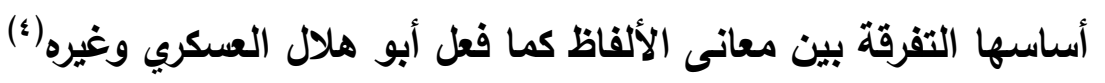
وقد اشتملت رواية ابن ماهان على ما يمكن إدراجه تحت هذه الظاهرة:

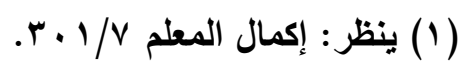

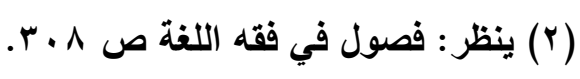

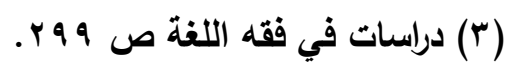

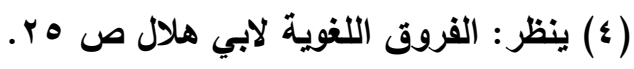




\section{ا. المدج والمبد}

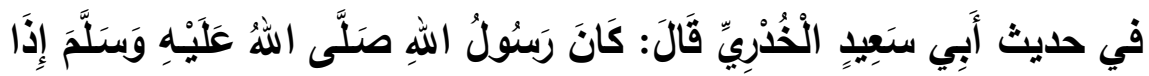

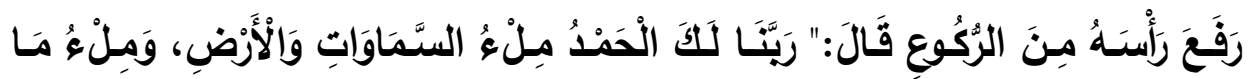

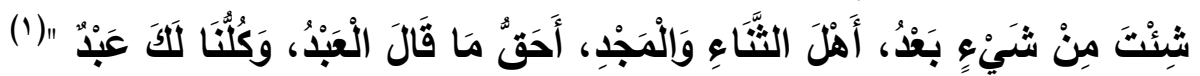

\section{الدراسة والتمليل}

اختلفت الرواية في قوله " أهل الثناء والمجد " فرواه الجمهور " أهل الثناء

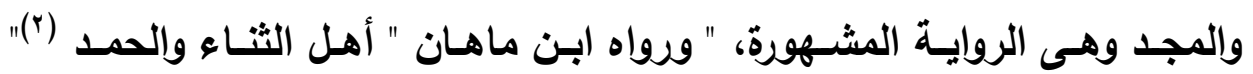

وعلى الرغم من ذهاب بعض العلماء إلى القول بترادف دلالة هذه الألفاظ وأنهان أنها تعني الثناء على الله تعالي وتثثريفه وتعظيمه حتى قال ابن العربي: " وكل واحد

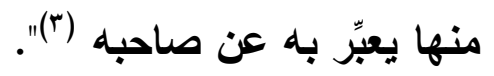

فإن بعض العلماء ذهب إلى التفرقة بين اللفظين " المجد والحمد " وهو

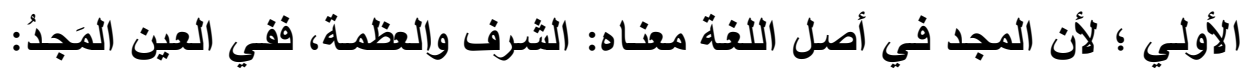

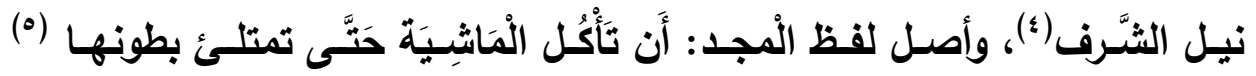

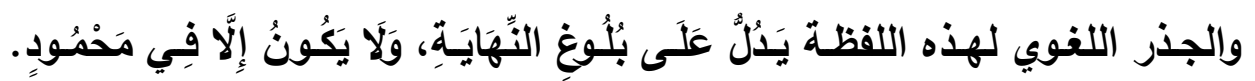

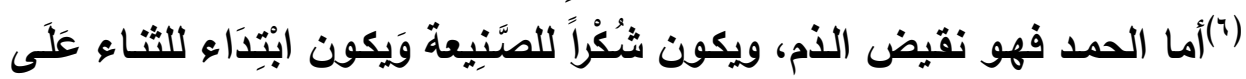

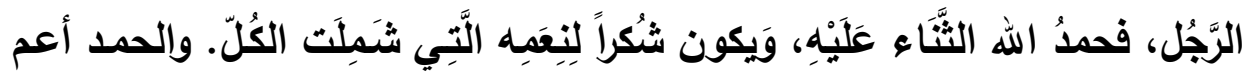

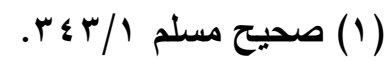

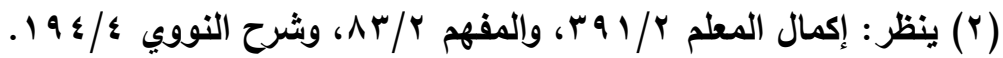

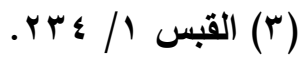

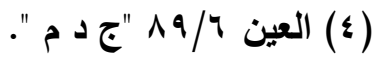

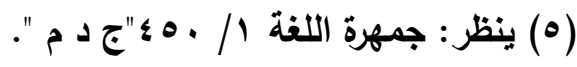

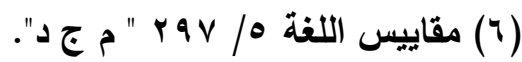


من الثكر لأنك تحمد الرجل على صفاته الذاتية وعلى عطائه ولا تثكره على

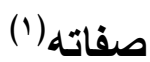

وممن فرق بين هذه الألفاظ الثلاثة القاضي عياض فقال: والفرق بين "

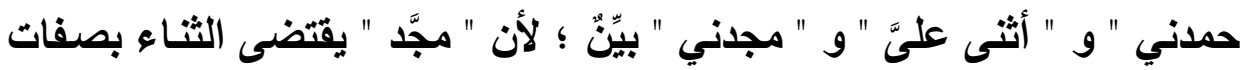

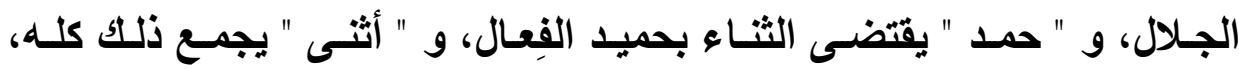

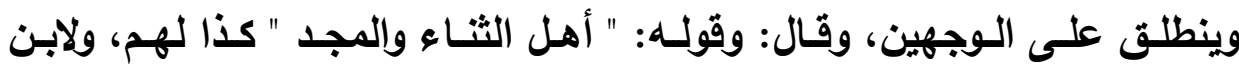

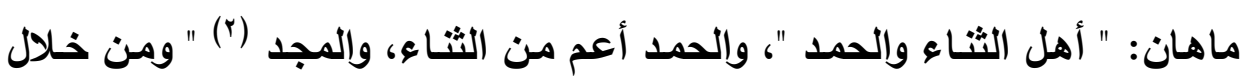

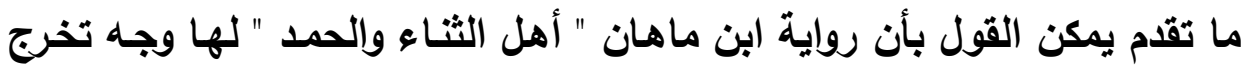

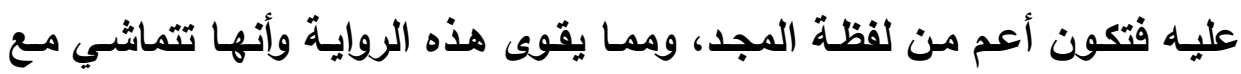

سياق الحديث قوله في بداية الحديث " للك الحمد "(").

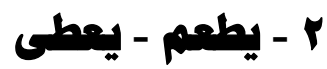

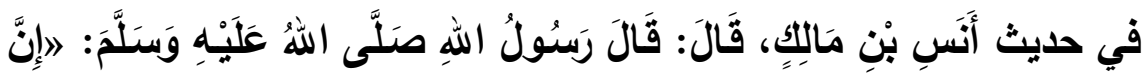

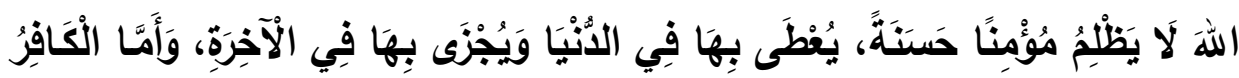

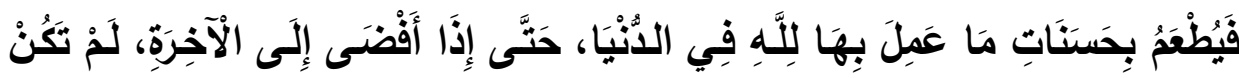

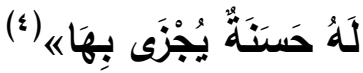

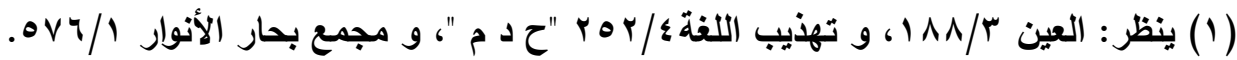

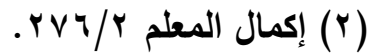

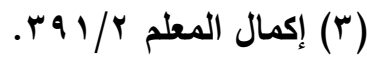

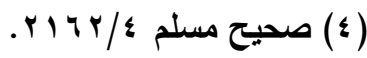




\section{الدراسة والتمليل}

سياق الحديث في بيان جزاء المؤمن بحسناته في الدنيا والآخرة، وتعجيل حسنات الكافر في الانيا، وقوله: "فيطعم بحسنات " هكذا رواه كافة الرواة، ورواه

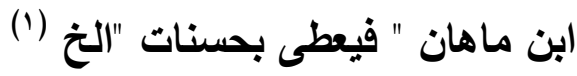

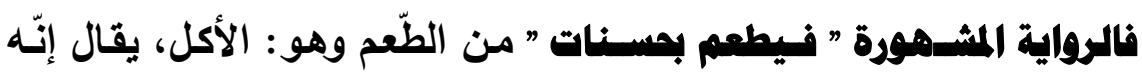

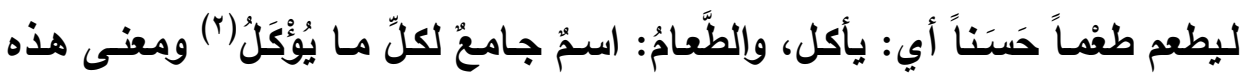

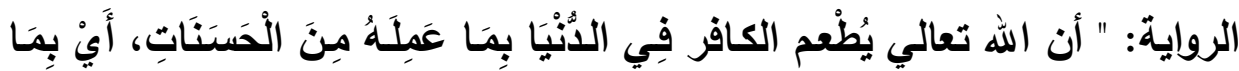

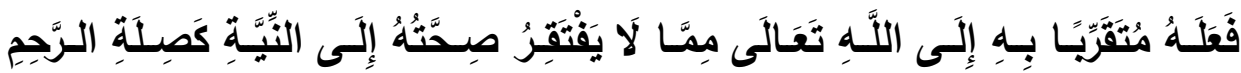

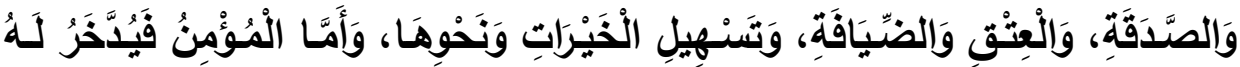

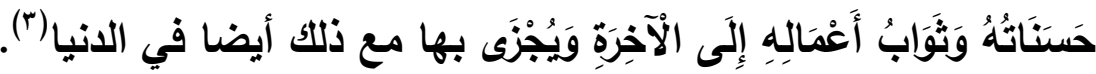
أهما رواية ابن ماهان " فيعطى بحساب " فهي من الإعطاء الأى هو مصدر

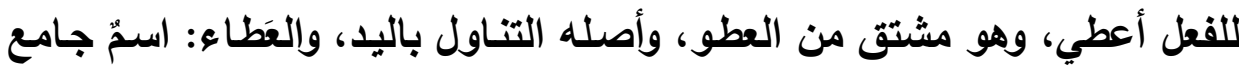

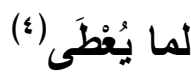

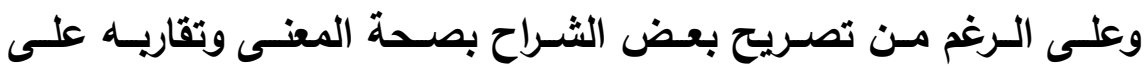

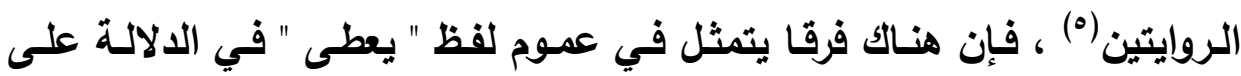
إثابة الكافر على ما يفعله من حنات في الانيا وهو ما أفادته رواية ابن ماهان

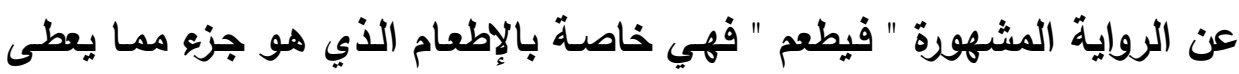

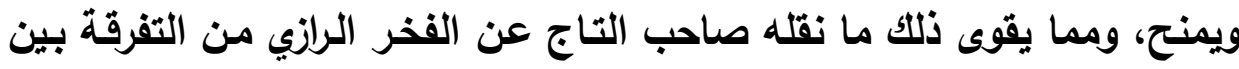

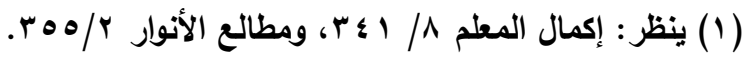

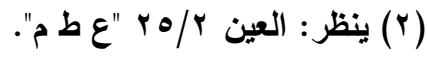

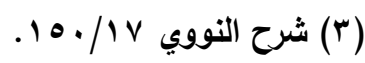

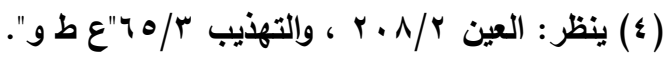

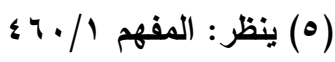




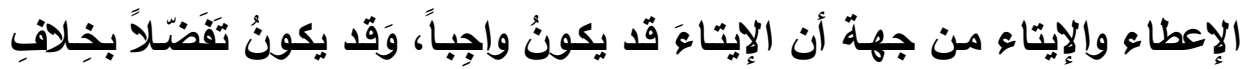

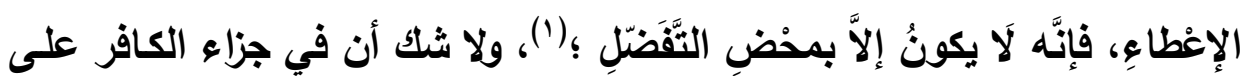
حناته بالانيا تفضلا وإنعاما من الله عليه فيناسبه لفظ الإعطاء دون الإطعام.

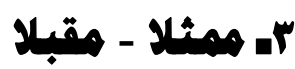

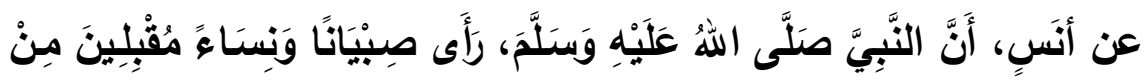

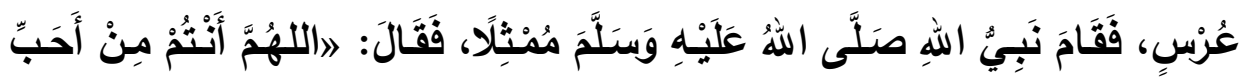

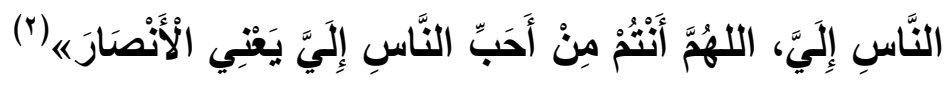

\section{الدراسة والتصليل}

الحديث في سياق بيان محبته صلي الله عليه وسلم للأنصار، وقوله " في

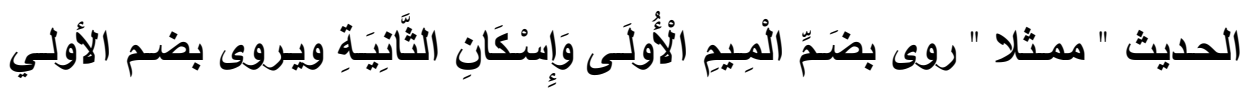

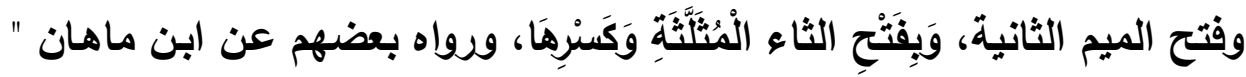
مقبلا) مقا").

أمسا الروايتان الأوليـان فتتخرجان على أنهما مأخوذتان من المثول وهو

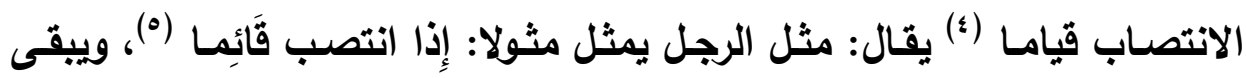
الفرق بينهما في كون رواية كسر الثاء على صيغة اسم الفاعل ويفتحها على لانى

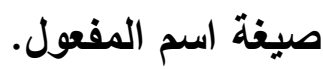

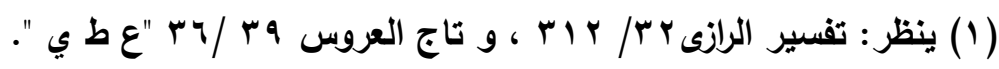

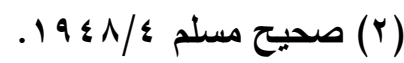

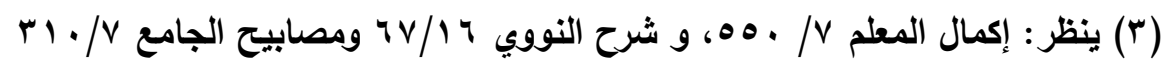

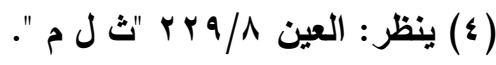

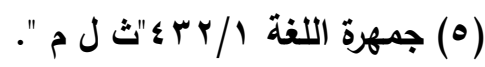


وقث اعترض على هاتين الروايتين بأنهما على هذا تكونـان مأخوذتين من

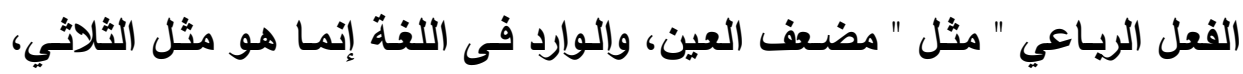
وعليه فاسم الفاعل منه ماثل، وأجيب عن هذا بأن قوله ممثُلا على إرادة التفعيل

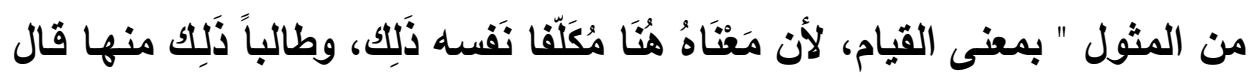

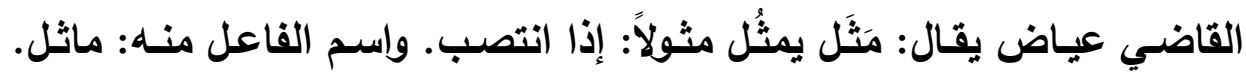

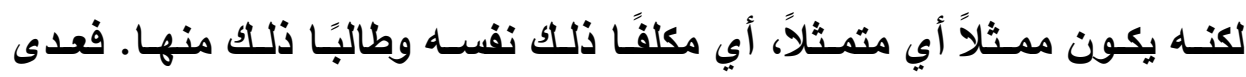
فعله (')

أما رواية ابن ماهان " مقبلا " فتوجه على أنها اسم فاعل من الفعل أقبل

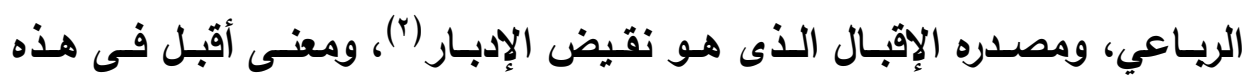

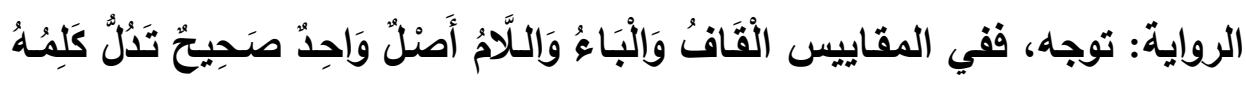

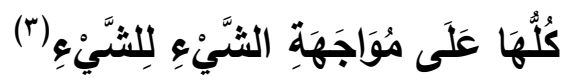

و بين الروايتين فرق يتمثل في العموم والخصوص فرواية ممثلا تفيد مجرد

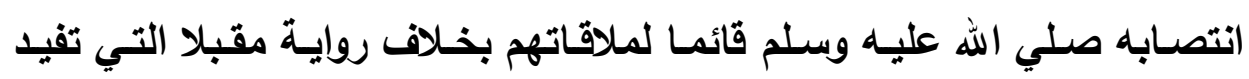

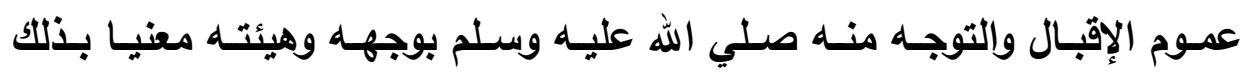

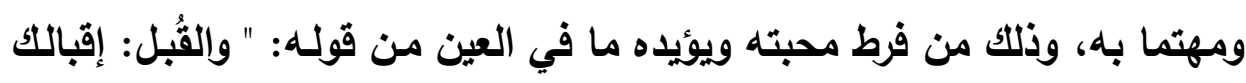

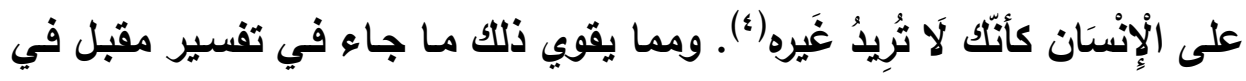

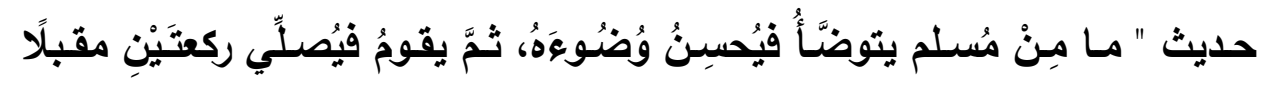

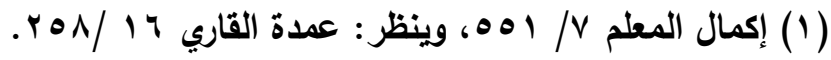

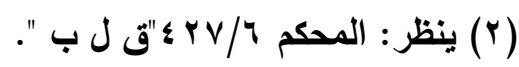

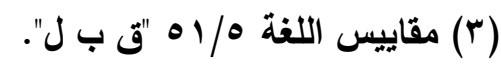

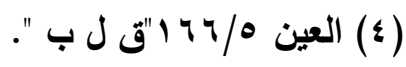




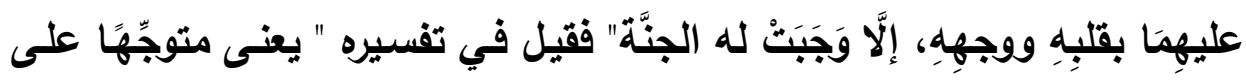

تلك الركعتين " بقلبه ووجهه"؛ يعنى: بظاهره وياطنه (')

\section{ثالثا: السياق وإلثره في تعيسن دلالة الرواية}

تمهيد: يلعب السياق دورًا مهما في تحديد دلالة الألفاظ، فهو وحده الذي يفرض قيمـة واحدة بعينها على الكلمـة بـالرغم من المعاني المتتوعـة التي في وسـعها أن تدل عليها، وهو الذي يخلص الكلمـة مـن الدلالات التي قد تتراكم

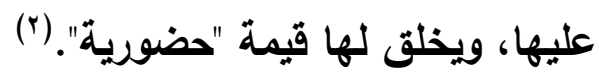

فالمعنَى الواحد للفظة مـا يتحدد على أسـاس عدد من القرائن اللفظيـة أو المقاميـة التي تخلصسه مـن الاحتماليـة الالالية. وتعدد روايـات الحديث النبوي مجال خصب لاراسـة أثر السياق في تقويـة أو تضعيف روايـة عن روايـة أخري وذلك بقدر ما تحتمله الرواية من تناغم مـع القرائن اللفظية أو المقامية، أو بعد عن تلك القرائن للحديث الشريف.

$$
1
$$

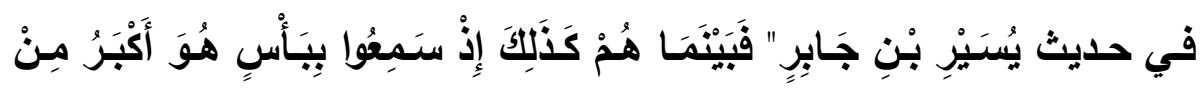

ذَنَلََِ.

\section{الدراسة والتمبيل}

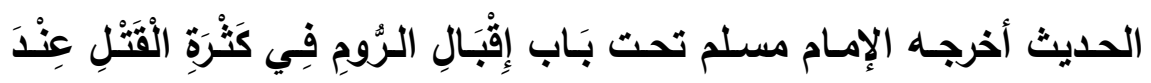

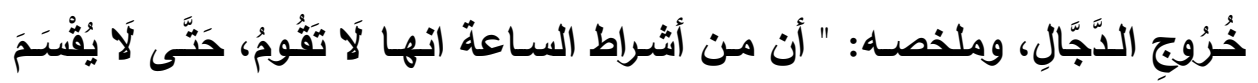

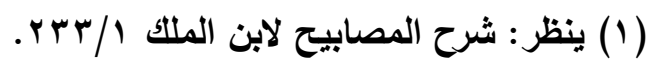

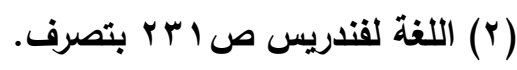

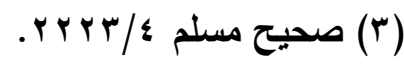




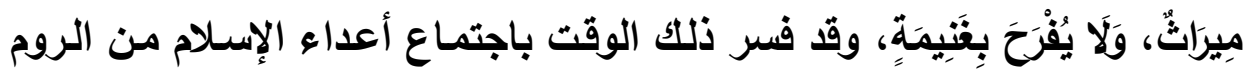

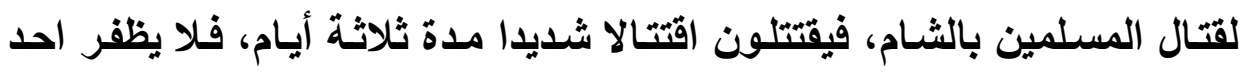

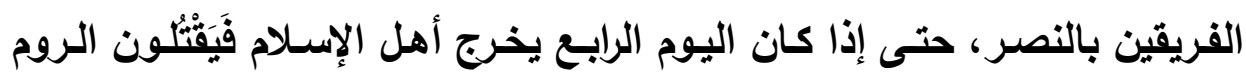

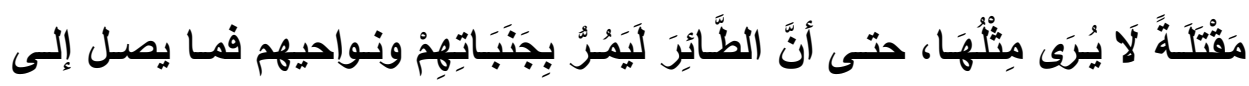

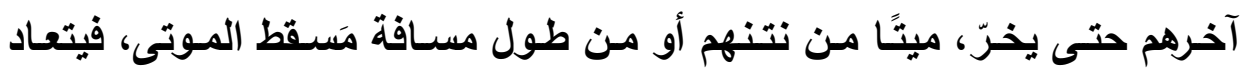

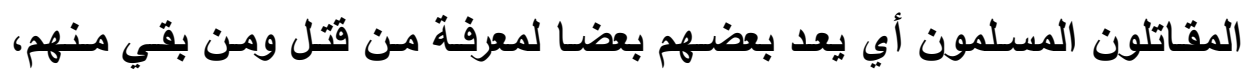

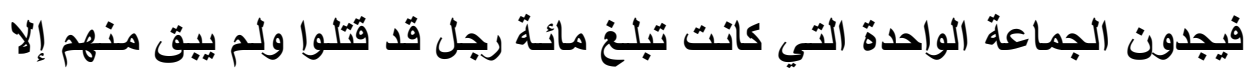

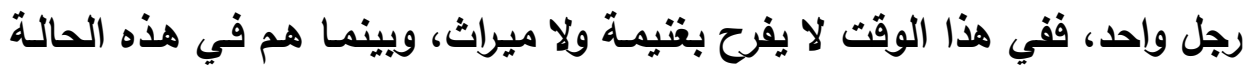

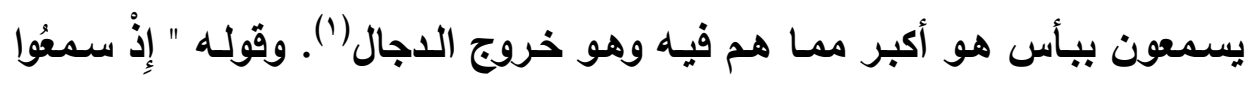

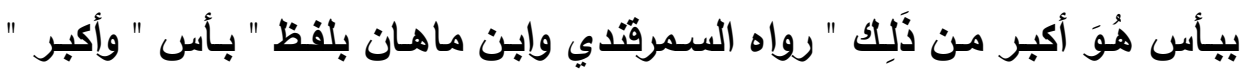

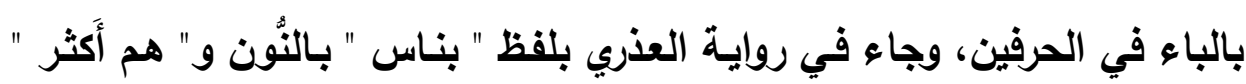

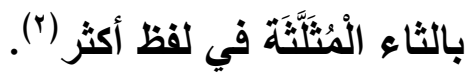
ورواية ابن ماهان " بيأس " بالباء هي الرواية المشهورة ومعناها: الحرب

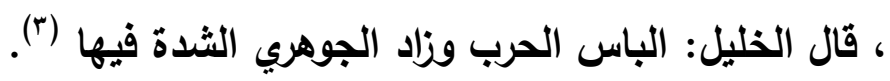
أما رواية " بناس" بالنون فأصلها أناس ويطلق على الجماعة مِنَ الإنس

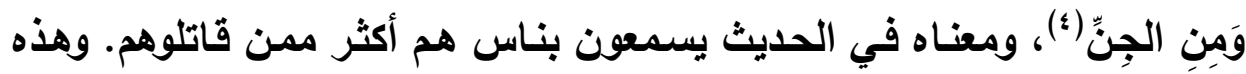

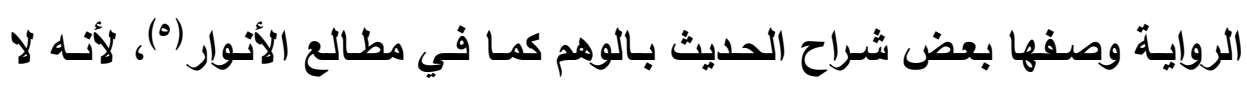
معنى يتناسب ميع هذه الرواية هنا، لأن سياق الحديث يدعم رواية ابن ماهـان

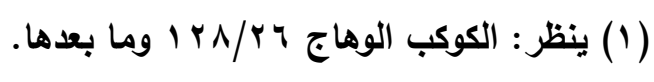

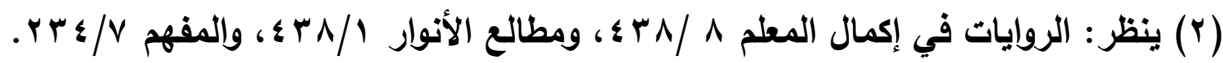

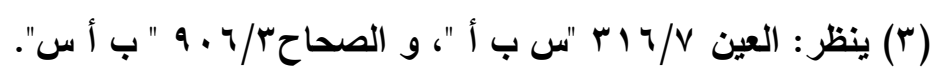

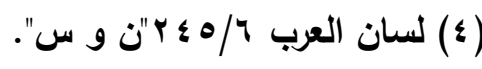
$.2 r \Lambda / 1(0)$ 


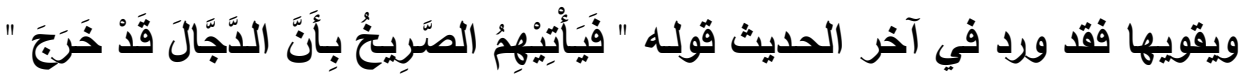
فهذا القول تفسير للبأس الأكبر على روايـة ابن ماهـان بمعنى الأمسر الهائل العظيم الذى هو أكبر من قتال الروم، وهو قتال الاجال وحريه.

كما يدعمها أيضـا مـا جاء في روايـة أبى داوود من قولـه " سمعوا بأمر

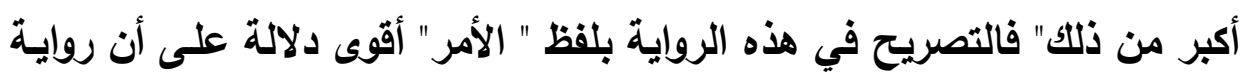

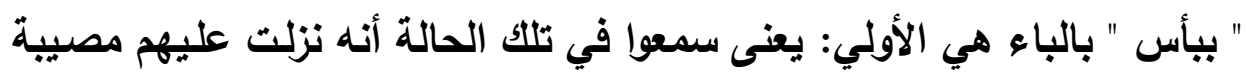

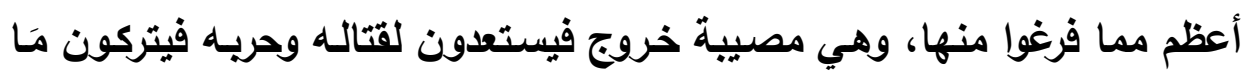

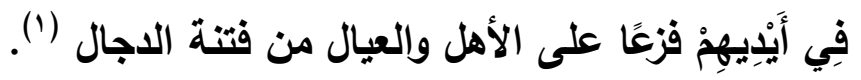

\section{r - توافوني بالصفا ويوافوني بالصغار}

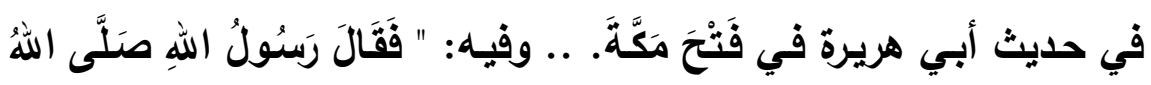

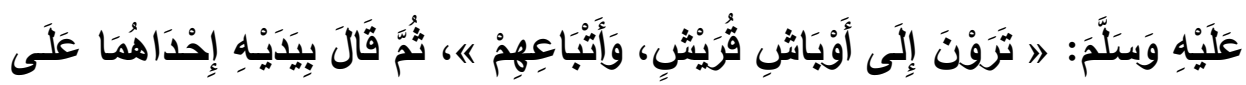

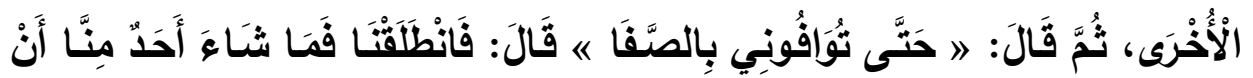

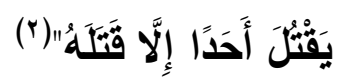

\section{الدراسة والتمليل}

الحديث في سياق بيان ما حدث يوم فتح مكة من إقبال رسول الله -صلى

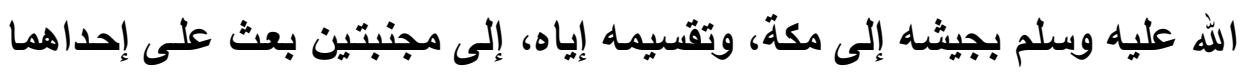

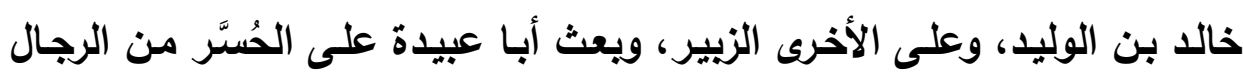

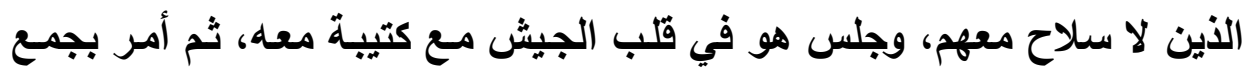

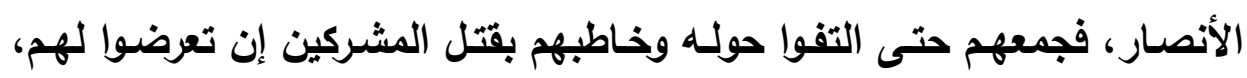

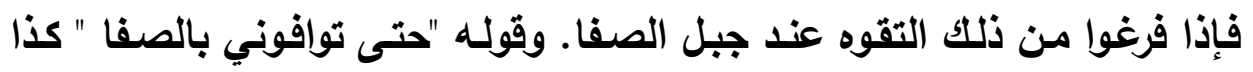

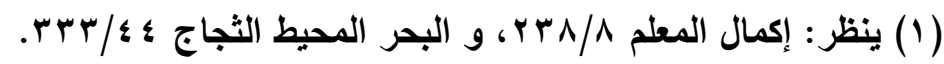

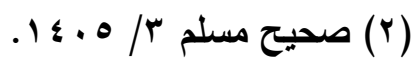


رواه كافـة الـرواة بلفظ " توافوني بالصفا، ورواه ابـن ماهـان بلفظ، " يوافوني

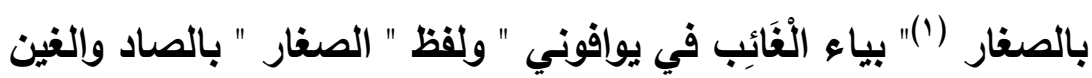

أمسا روايـة الكافة " توافوني بالصفا " فتوافوني " فيها مضارع أوفى، يقال

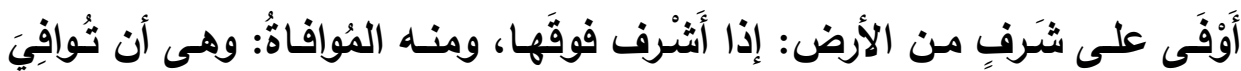

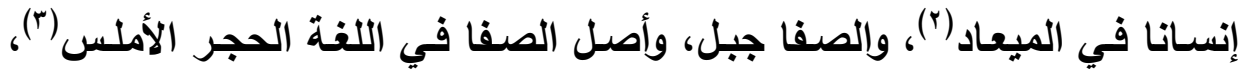

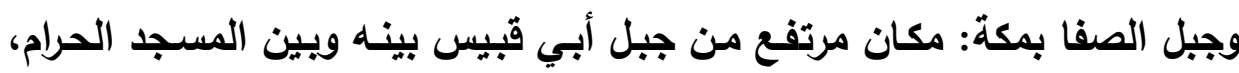
عرض الوادي الذي هو طريق وسوق، وإذا وقف الواقف عليه كان حذاء الحجر

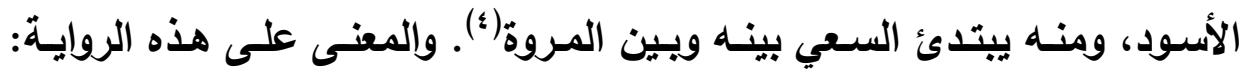
اقتلوا المشركين حتى إذا أنهيتم ذلك فالتقوني على جبل ولئ الصفا.

أمـا روايـة ابن ماهـان " يوافوني بالصـغار " هكذا بيـاء الْفَائبَ، والصـغار

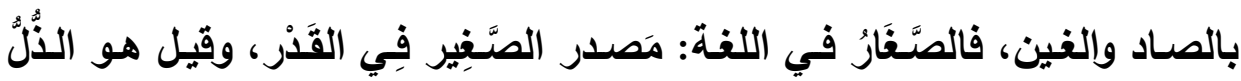

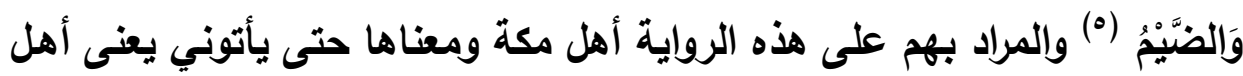

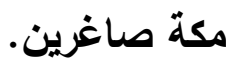

ومن خلال التحليل اللغوي للروايتين نستطيع القول بأن رواية ابن ماهان "

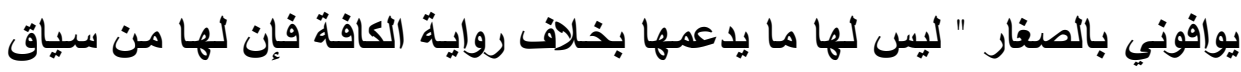

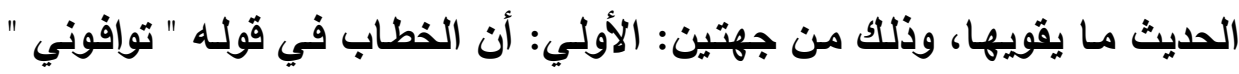

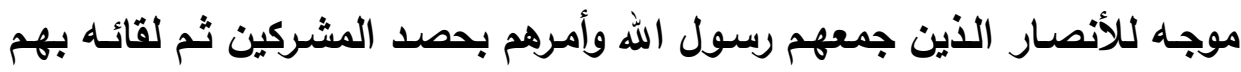

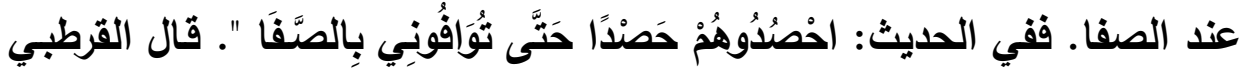

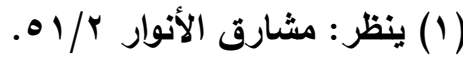

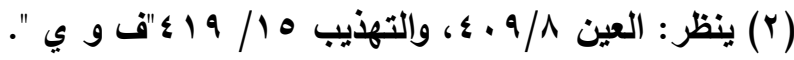

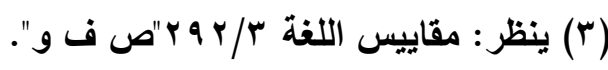

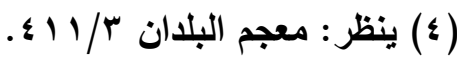

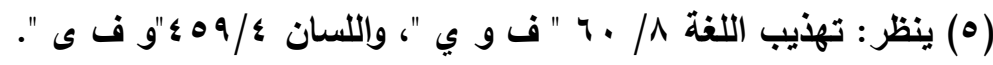


" ظاهره خطابه للأنصار ، فكأنه -صلى الله عليه وسلم - سلك الطريق الأعلى

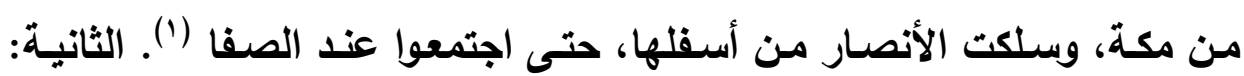

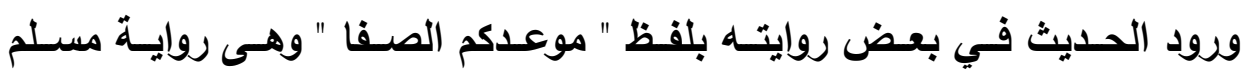

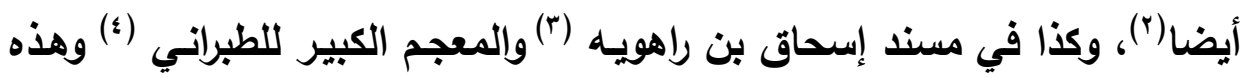

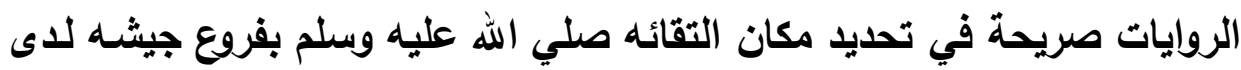

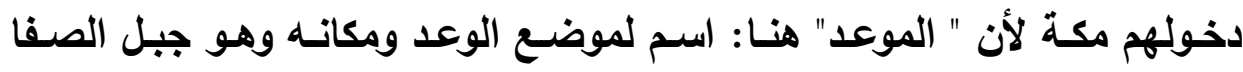
بمكة.

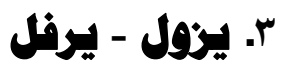

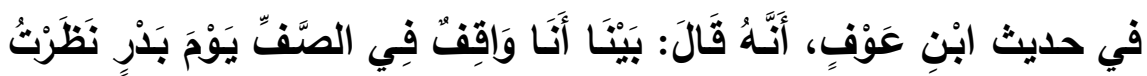

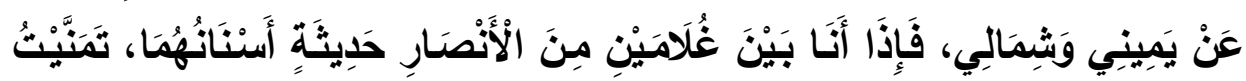

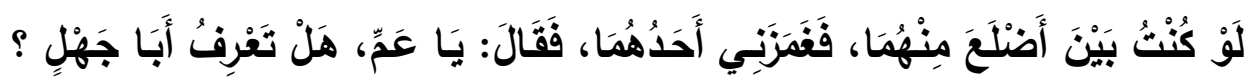

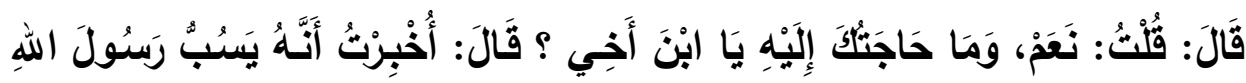

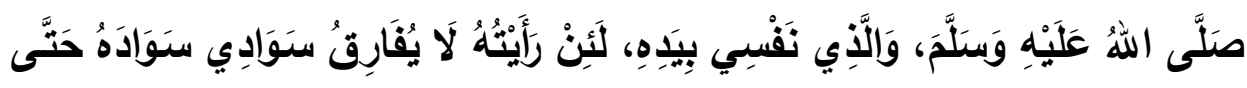

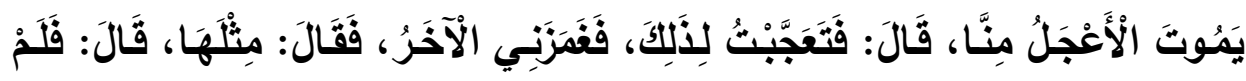

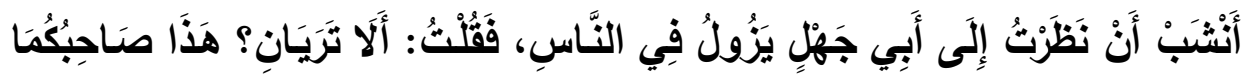

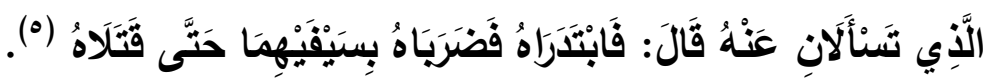

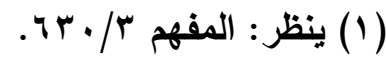

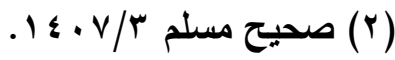

$$
\begin{aligned}
& \text {. } 499 / /(r) \\
& .1 \% / \Lambda(\xi) \\
& \text { (0) صحيح مسلم TVY/T (8) }
\end{aligned}
$$




\section{الدراسة والتمليل}

الحديث في سياق ذكر ما حدث فى غزوة بدر، وقتل أبي جهل، وقد روى قوله " يزول " هكذا بالزاي والواو والللام، وهى روايـة الجمهور، ورواه ابن ماهـان

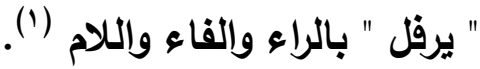

أما رواية الجمهور " يزول " فتوجه على أنه فعل مضارع من زال يزول:

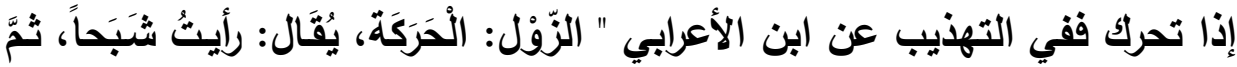

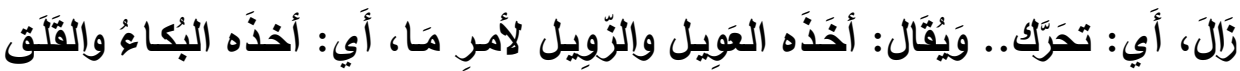

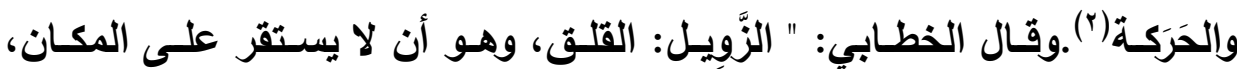

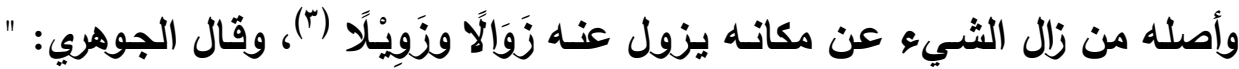

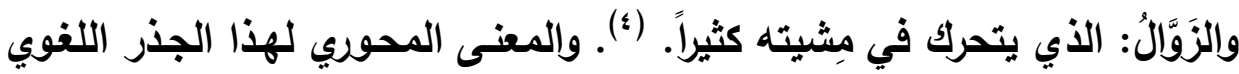
يدور حول تحرك الثيء انتقالًا عن موضعه بخفة - كزوال الثيء والثبح عن لنه

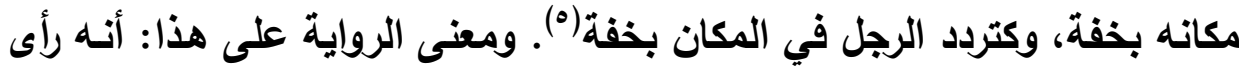
أبا جهل يتحرك فى الناس يوم بدر كأنه يحثهم على القتال فلا يستقر علي حال.

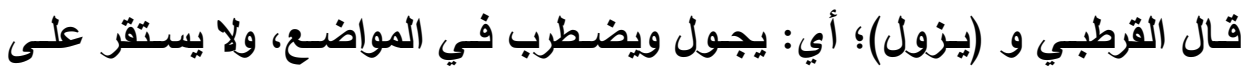

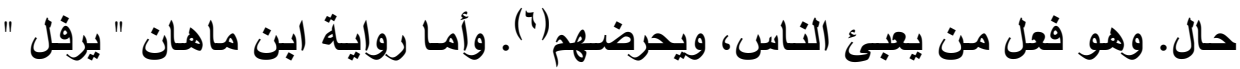

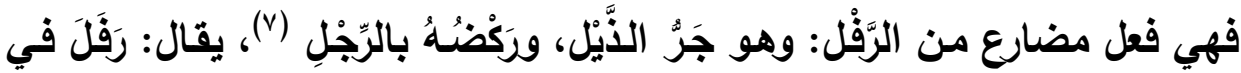

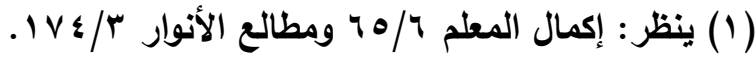

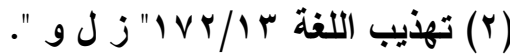

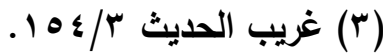

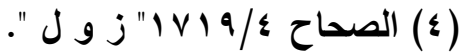

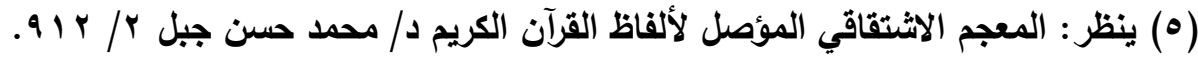

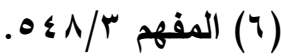

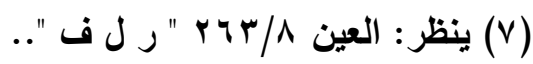




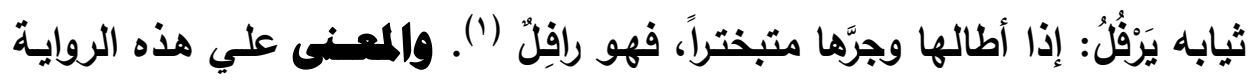

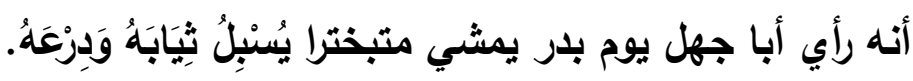

وعند الاحتكام لسياق الحديث هنا نستطيع أن نقرر أن رواية الجمهور "

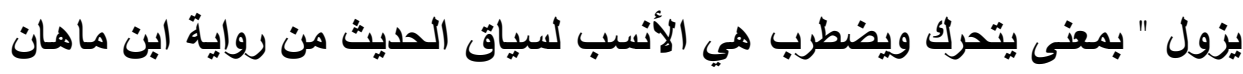

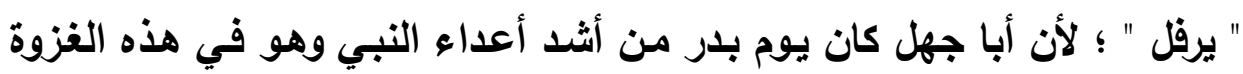

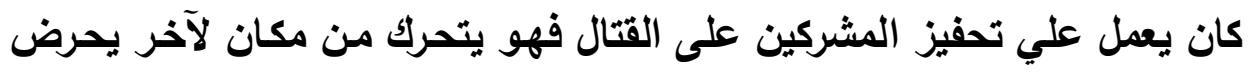

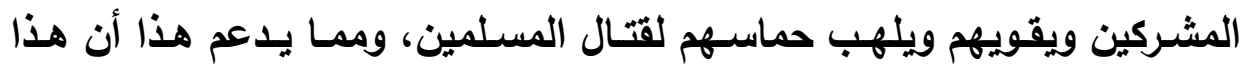

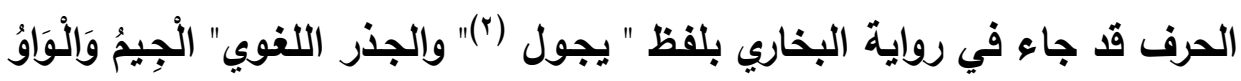

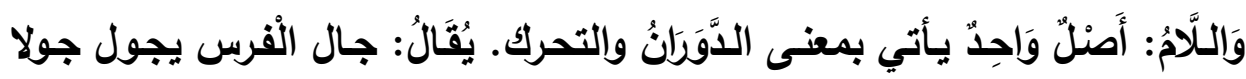

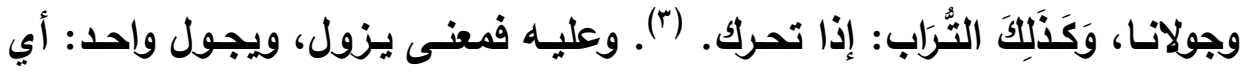
اضطرب ولا يستقر على حال. وهذا ما عناه بعض شراح الحديث من تقويتهم

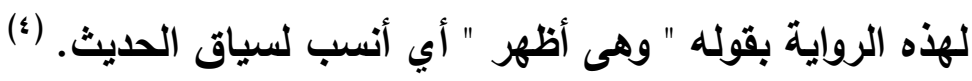

ومع تقوية السياق لرواية الجمهور " يزول " فإنه من المكن قبول رواية

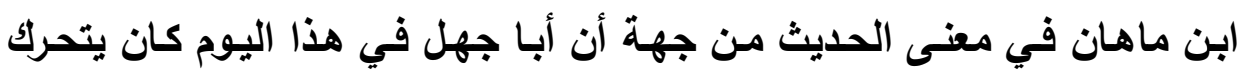

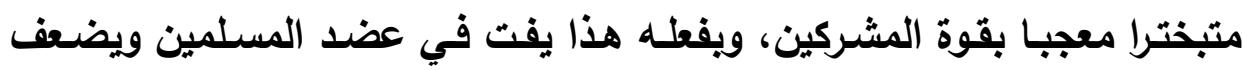
قواهم من رؤيتهم لله بهذه الهيئة من الفخر والإعجاب بالنفس.

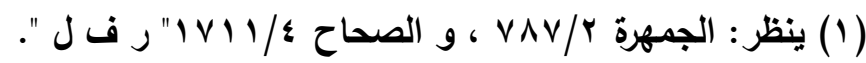

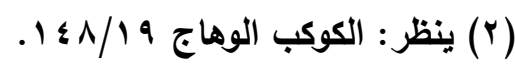

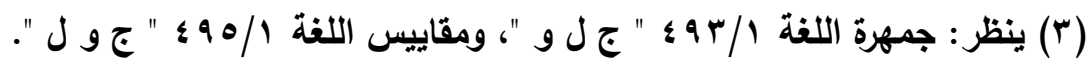

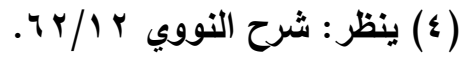




\section{رابعا: التصميف والتصريف وأثرهما الدلالي}

من المصطحات الدائرة في التراث اللغوي مصطلحا التحريف والتصحيف وقد نقل السيوطي عن المعري قوله: " أصل التصحيف أن يأخذ الرجلُ اللفظ من فئن

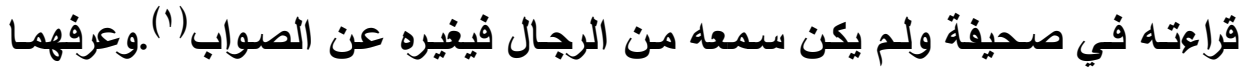

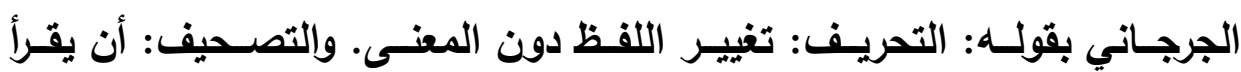
الثيء على خلاف ما أراد كاتبه، أو على ما اصطلحوا عليه (ץ). وظاهرة التصحيف والتحريف من الظواهر المنتثرة في التراث اللغوي وقتّمسا

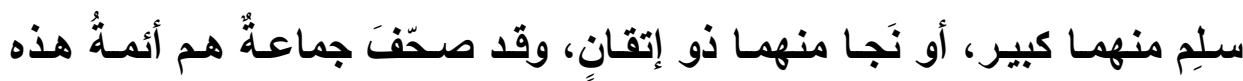

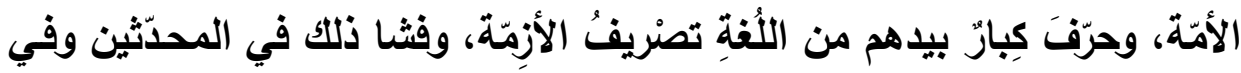

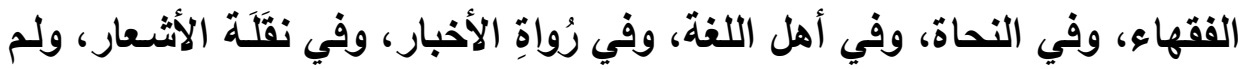

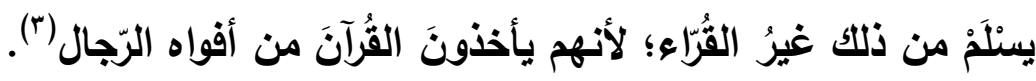
وقد جاء في روايات الأحاديث النبوية عدد من الألفاظ وقع فيها التصحيف والتحريف، ولم تخل رواية ابن ماهان أو غيره لأحاديث صحيح مسلم من ذلك:

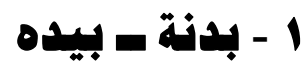

في حديث جابر بن عبد الله، رضى الله عنه وقد سئل عن حَجَّةِ رَسُولِ اللهِ

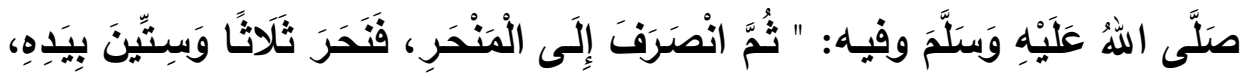

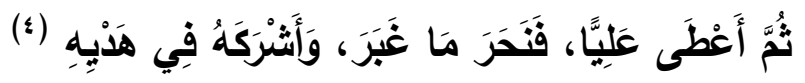

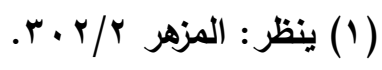

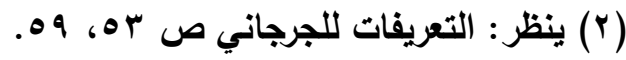

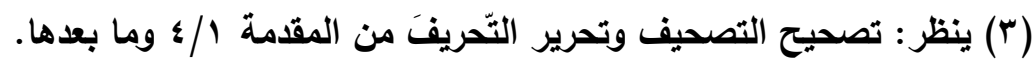

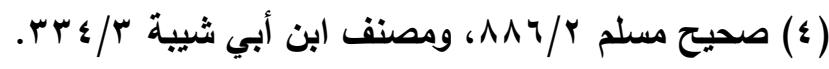




\section{الدراسة والتمليل}

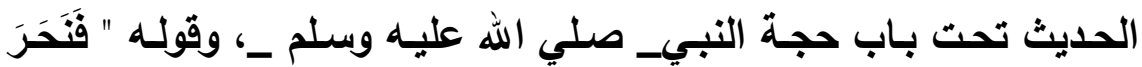

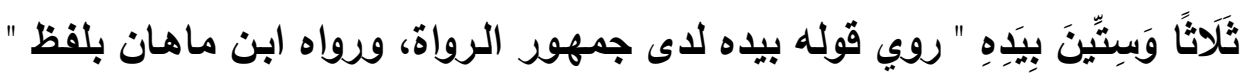

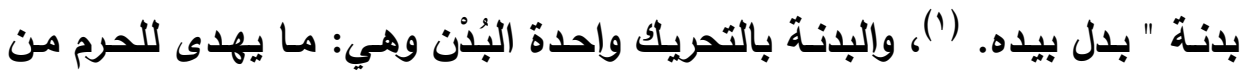
الإبل أو البقر. قال الأزهري:

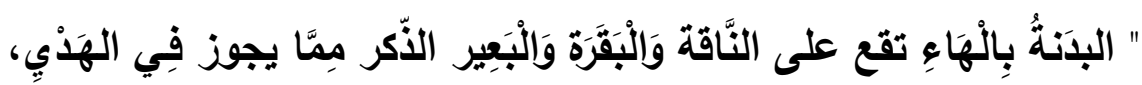

وَالْأَضَاحِي (r)

ويبدو أن لفظ " بيده " قد صحف في روايـة ابن ماهان إلى لفظ " بدنـة "

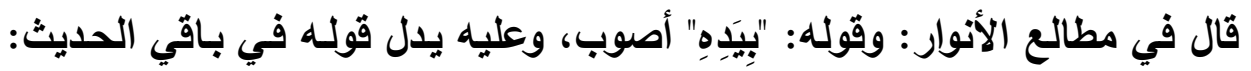

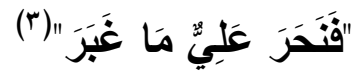

وعلى الرغم من تغاير الروايتين فهما صحيحتان من جهة المعنى ؛ لأنها.

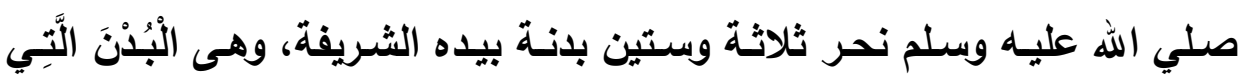

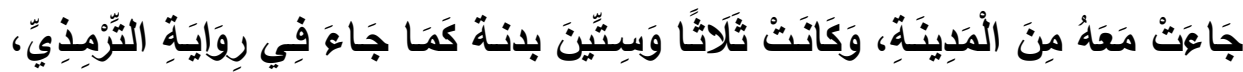

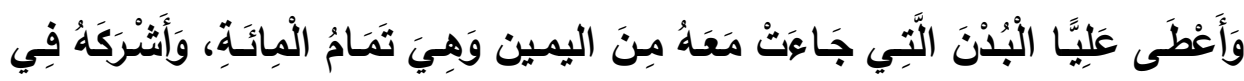

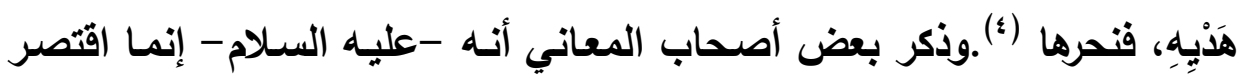

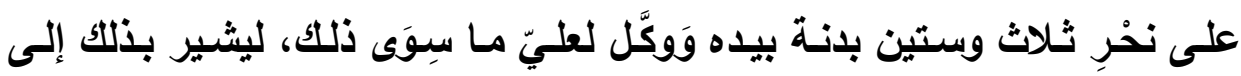

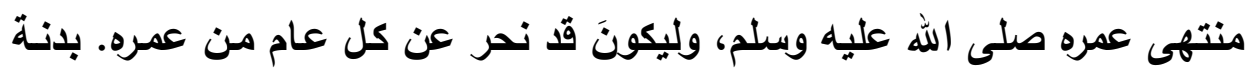

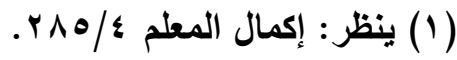

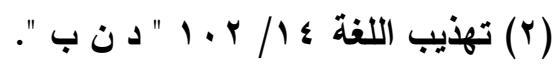

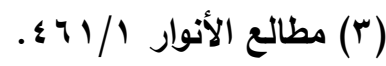

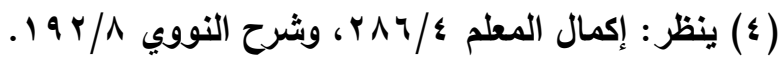




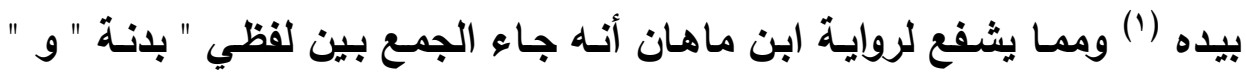

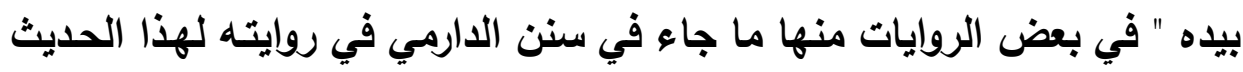

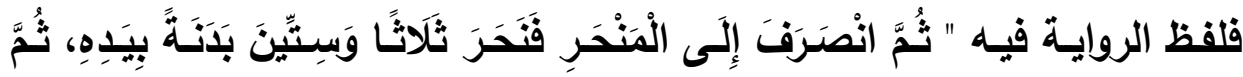

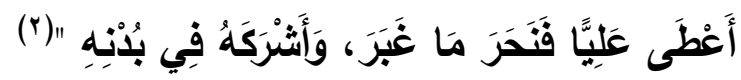

\section{r}

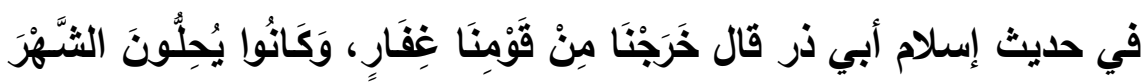

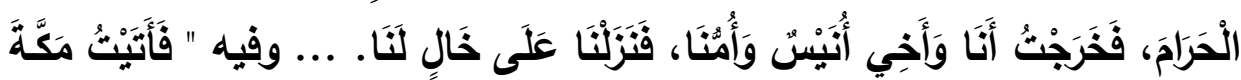

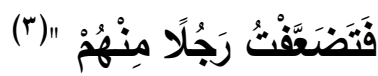

\section{الدراسة والتمليل}

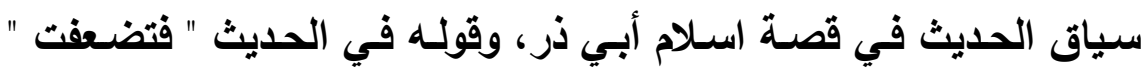

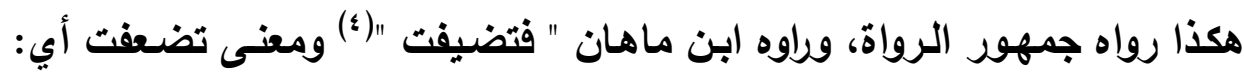

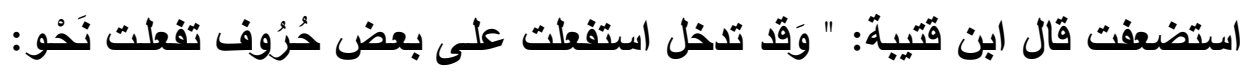

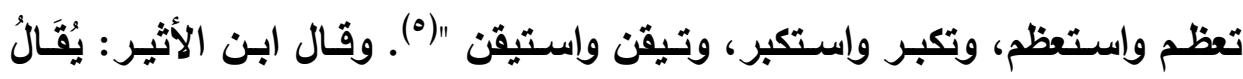

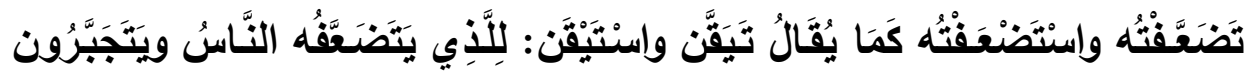

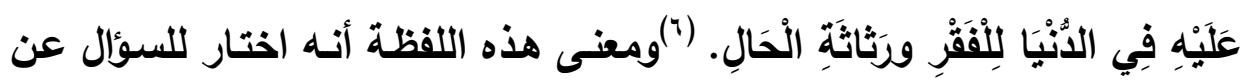

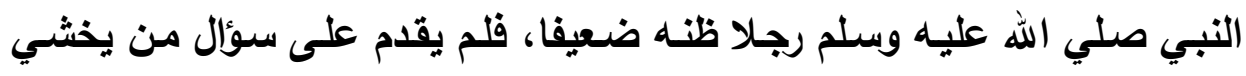

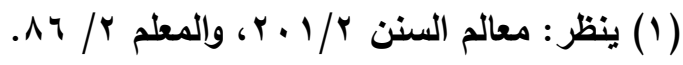

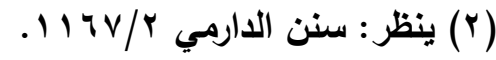

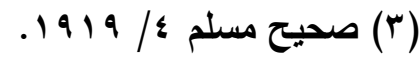

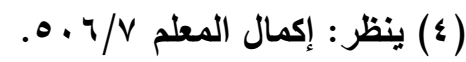

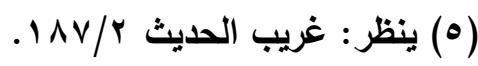

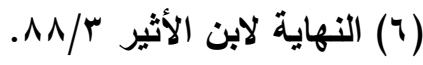


منه ويتوقع أذاه، ولِأَنْ الضَّعِيف مَأْمُون الغائلة غَالِبا. (') وقد ذكر شراح الحديث

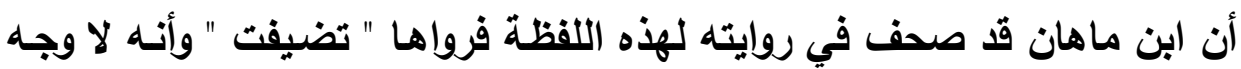

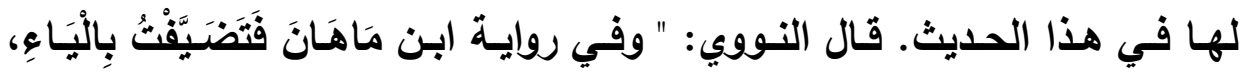

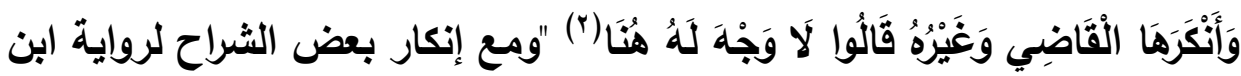

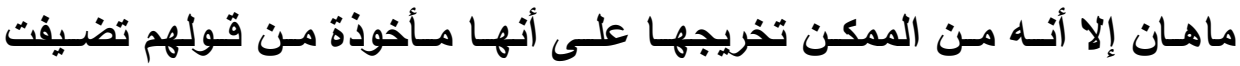

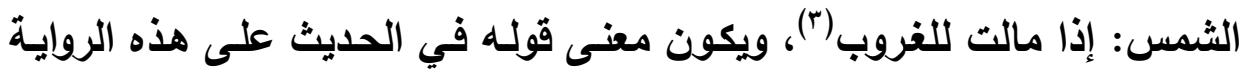
فتضيفت " أي ملت إلى رجل أسأله عن النبي عليه السلام.

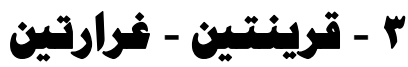

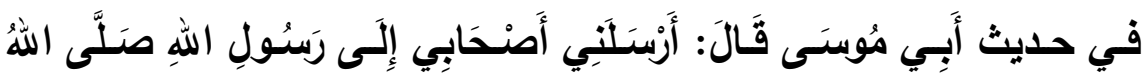

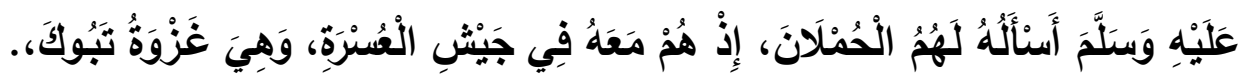

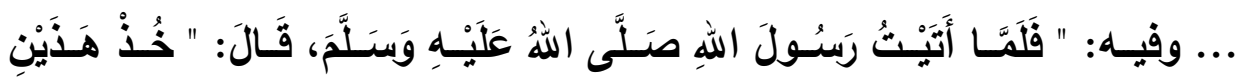

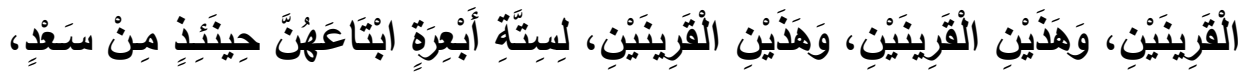

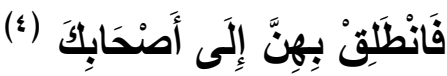

\section{الدراسة والتمليل}

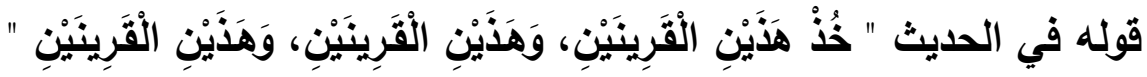

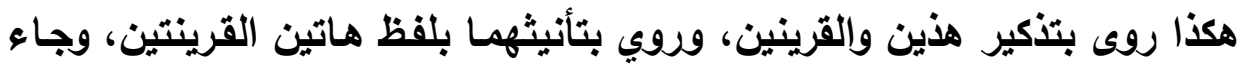

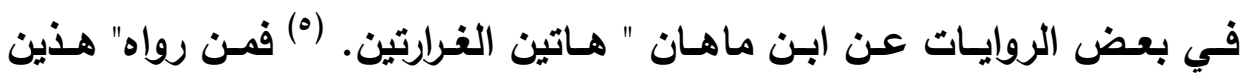

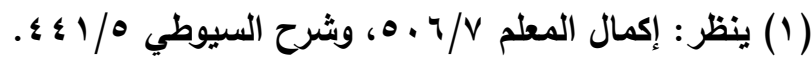

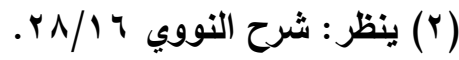

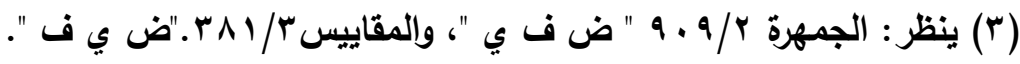

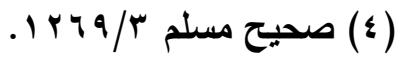

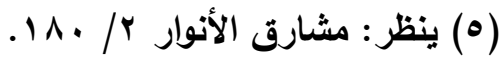


القرينين" فهذين: اسم إثـارة للمثـى للمذكر، والقرينان: هما: البعيران المقرونان

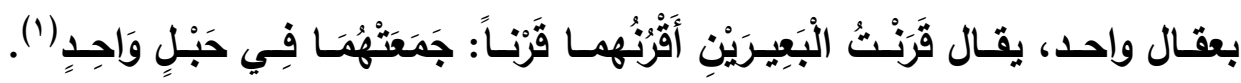

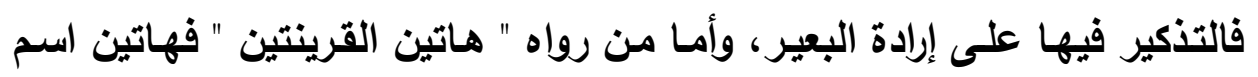

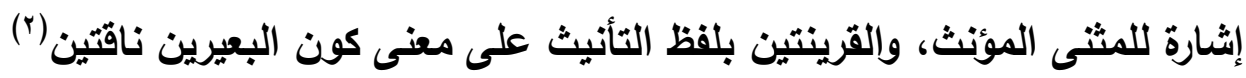

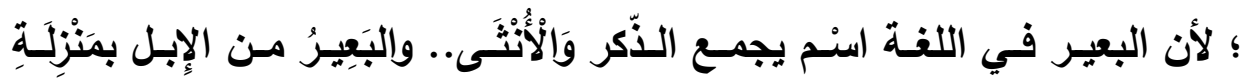

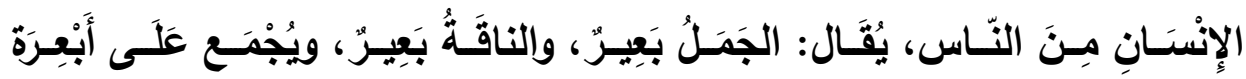

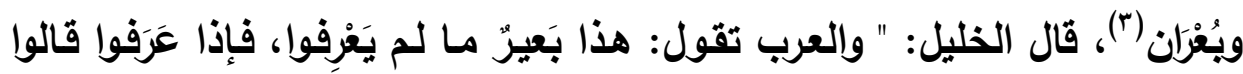

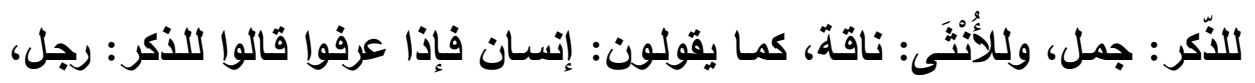

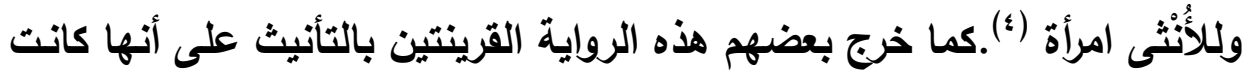

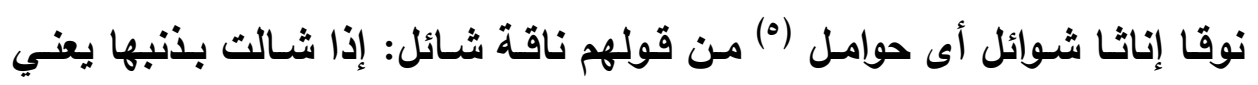

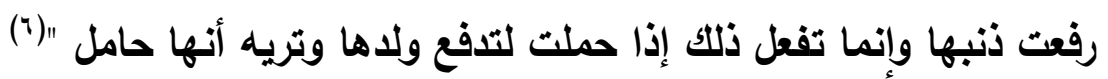
أما رواية ابن ماهان " هاتين الغرارتين" ففي توجيهها أن هاتين اسم إثـارة

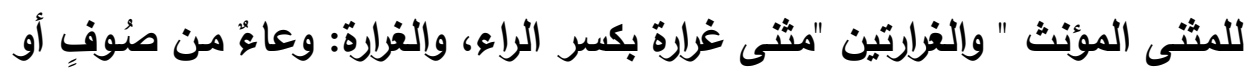

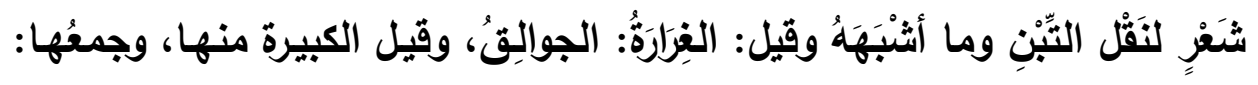

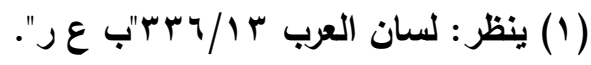

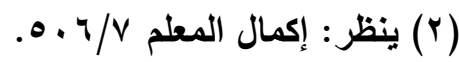

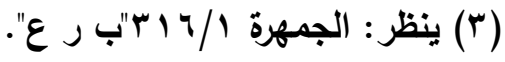

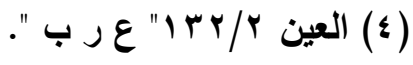

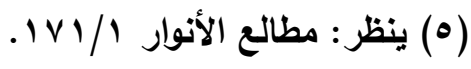

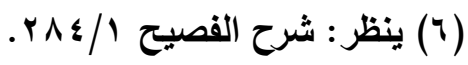




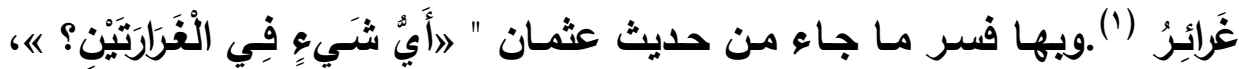

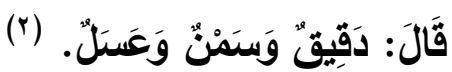

ومن خلال ما تقدم نستطيع القول بوقوع التصحيف في رواية ابن ماهان"

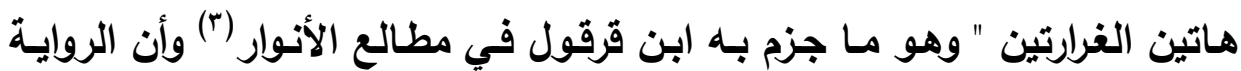
الأصسوب هـي لفظ "القرينين أو القرينتين "، لأن سياق الحـيث يـاعم تفسير القرينين أو القرينتين بالبعيرين أو الناقتين المقرون أحدهما بصاحبه في عقال

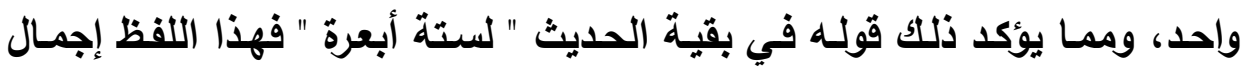

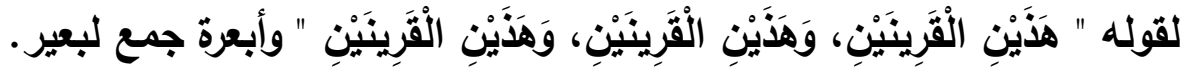
وأيضا ما جاء في رواية من روايات هذا الحديث من قوله " فأمر لنا

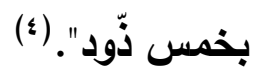

والذَّْدُد من الإِبِل: من الثَلاث إلى العشر (0)، فلفظ الذود في هذه الروايـة

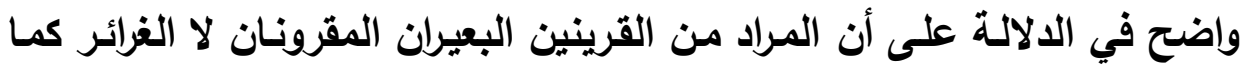
روى ابن ماهان.

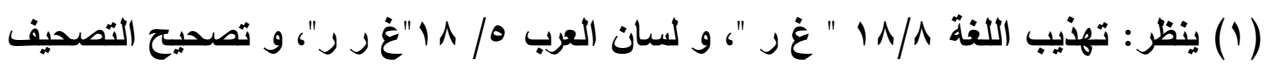

$$
\text { ص } 9 \text { ب. }
$$

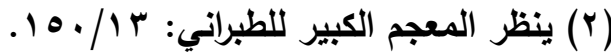

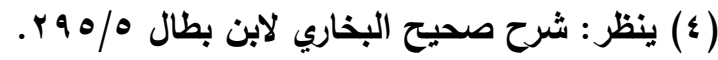

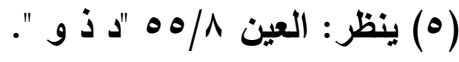




\section{الـنــاتـمة}

الحمد الله في الافتتاح والاختتام، والصـلاة والسـلام على خير الأنـام، نبينـا محمد خاتم الرسل الكرام، وعلى آله وصحبه أجمعين.

\section{פי-}

فقد فرغت ـ بعون من الله وتوفيقه ـ من هذا البحث الذي تضمن دراسـة

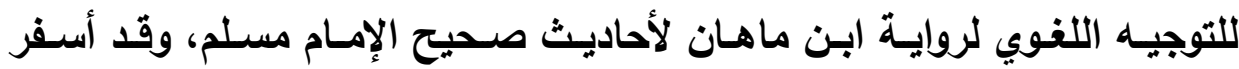

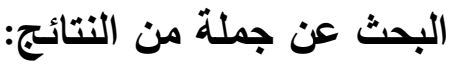

أولا: روايـة ابن ماهان لأحاديث صحيح مسلم من الروايات المعتمدة للصحيح ، وقد اعتمدها شراح الدديث ، بل هي الرواية الأم لاى المغارية.

ثانيا: مجيء رواية ابن ماهان على الأصل اللغوي في تحقيق الهمز لاى العرب مقابل التسهيل في رواية غيره.

ثالثا: موافقة رواية ابن ماهان للقياس في تخفيف الهمزة بإبدالها واوا في واخيت كطريق من طرق تذفيف الهمزة المفتوحة المضموم ما قبلها

رابعا: جريان رواية ابن ماهان على الأصل في الهمزة في ييتئر في مقابل ابدالها

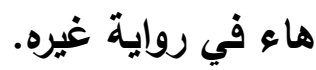

خامسـا:موافقة روايته للغة أكثر العرب وجمهورهم في فك الادغام في الفعل المضاعف المسند لضمائر الرفع. سادسا: رواية ابن ماهان موافقة للأصل اللغوي في تعدى الفعل تفصي. سـابعا: روايته برفع لفظ " جذع " ظاهرة من الوجهة الإعرابية ولا تحتاج لتأويل بخلاف رواية غيره. 
ثامنا: السياق يدعم رواية ابن ماهان "يتفقرون " بتقديم الفاء على القاف. تاسعا: السياق يقوي رواية ابن ماهان " ببأس أكبر " بالباء في الحرفين عاشرا: مجيء العياق مخالف لرواية ابن ماهان في يوافوني بالصغار. حادي عشر: رواية ابن ماهان " فتضيفت " لها وجه لغوى تحمل عليه بدلا من

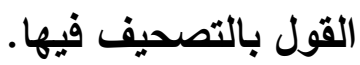




\section{فـهـرس الـمسادر والـمسراجه8}

\section{مرف الهمزة}

1. الإبدال لأبى الطيب اللغوي ـ تحقيق د/ عز الدين التنوخي ـ دمشق الـو ام. r. آثار البلاد وأخبار العباد للقزويني - ط/ دار صادر بيروت. r. أساس البلاغة للزمخشري ـ تحقيق/ محمد باسل عيون السود - نثر: دار الكتب

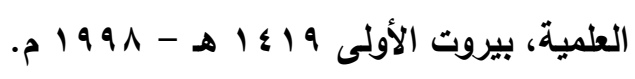

ع. إصلاح المنطق لابن السكيت - تحقيق/ محمد مرعب - ط/ دار إحياء التراث العربي

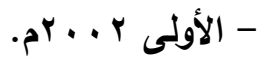
ه. الأصوات اللغوية د /إبراهيم أنيس - نشر/مكتبة الأنجلو المصرية - القاهرة - الخامسة . $19 \vee 0$ צ. الأعلام للزركلي نشر : دار العلم للملايين الطبعة: الخامسة عشر - أيار/ مايو ؟ . . Yم.

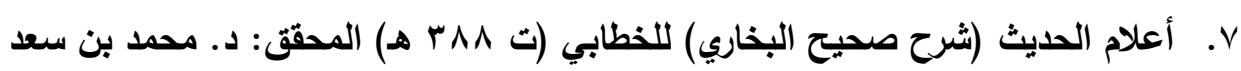

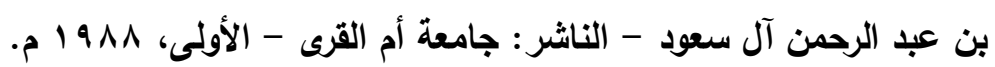
^. الإفصاح عن معانى الصحاح لابن هبيرة - تحقيق/ فؤاد عبد المنعم أحمد - الناشر : دار

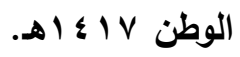

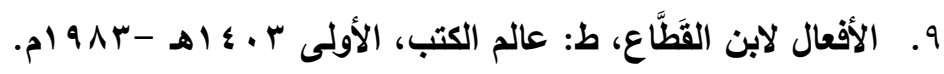

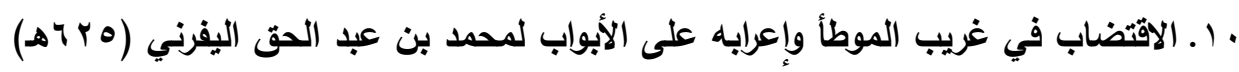

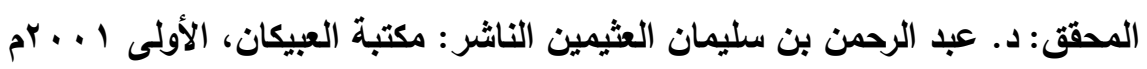

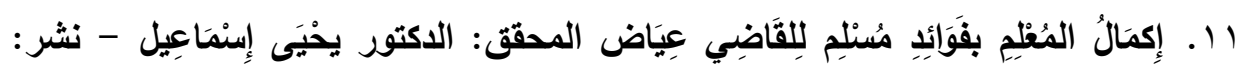

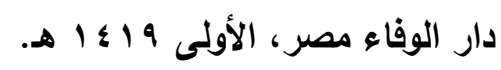

rا. . الألفاظ لابن السكيت - تحقيق د. فخر الدين قباوة الناشر: مكتبة لبنان ،الأولى . 1991

rا. الأنساب للسمعاني - تحقيق /عبد الرحمن بن يحيى اليماني وغيره - الناشر: مجلس

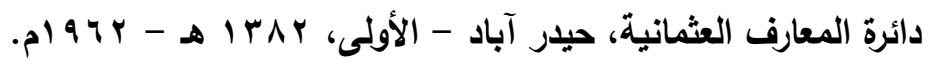




\section{هرف الباء}

ـ ا. البحر المحيط الثجاج في شرح صحيح الإمام مسلم بن الحجاج لمحمد بن علي بن آدم

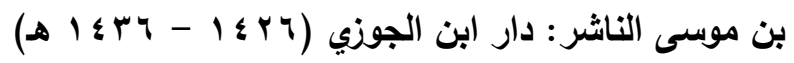

\section{مرف التقاء}

10. تأويل مشكل القرآن لابن قتيبة - تحقيق/ ابراهيم شمس الدين - نشر/ دار الكتب

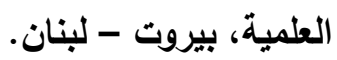

17 ا ـ تاج العروس من جواهر القاموس للزبيدي - تحقيق/ جماعة من المحققين - ط/ دار الهداية - دون تاريخ

V ا . تاج اللغة وصحاح العربية تحقيق/ أحمد عبد الغفور عطار - ط/ دار العلم للملايين

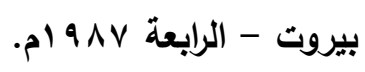

11. تاريخ الإسلام ووفيات المشاهير والأعلام لشمس الدين الأهبي تحقيق/ عمر عبد

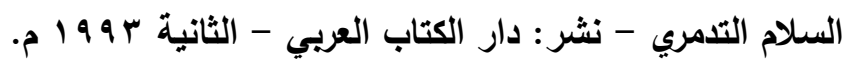

19. تاريخ بغداد للخطيب البذادي - تحقيق/ بشار عواد معروف - ط/ دار الغرب بيروت

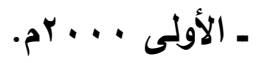

• r. تاريخ نيسابور لمحمد بن عبد الله بن البيع - تلخيص الخليفة النيسابوري - طان كتابخانة ابن سينا طهران.

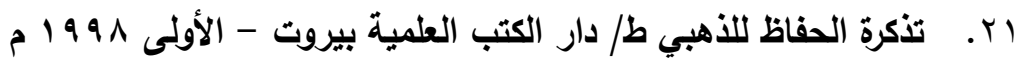
r r. تصحيح التصحيف وتحرير التحريف للصفدي - تحقيق/ السيد الثرقاوي - نشر:

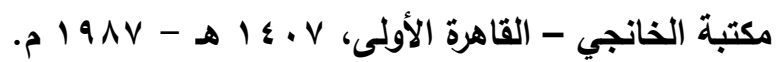
بr. التعريفات للجرجاني ط/ دار الكتب العلمية الأولي rیه ام. צ r. التعليق على الموطأ في تفسير لغاته وإعرابه ومعانيه للوقثى - تحقيق د/عبد الرحمن

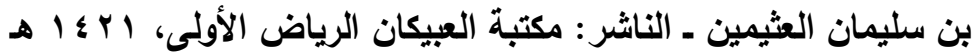
0. ت تفسير غريب ما في الصحيحين " للحميدي - تحقيق د/ زبيدة محمد سعيد عبد العزيز

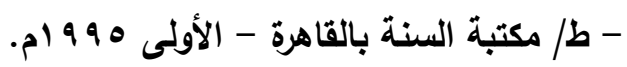


بr. التمهيد في علم التجويد لابن الجزي تحقيق د/ على حسين البواب - ط/ مكتبة

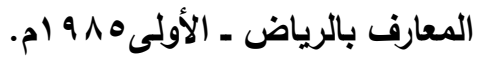

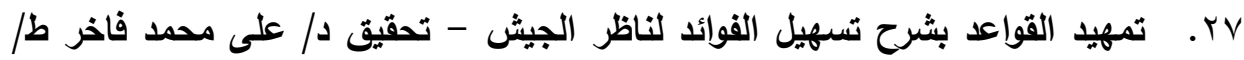

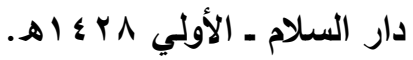

^ץ. التمهيذ لما في الموطأ من المعاني والأسانيد لابن عبد البر - تحقيق: مصطفى بن أحمد العلوي ، ومحمد عبد الكبير البكري - الناشر: وزارة عموم الأوقاف والثؤون

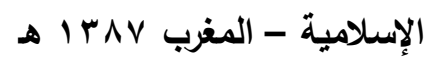

وץ. تهذيب التهذيب لابن حجر - ط/ مطبعة دائرة المعارف النظامية، الهند، الأولى ATrT

• r. تهذيب الكمال في أسماء الرجال للحافظ للمزي - تحقيق/ د. بشار عواد معروف - .

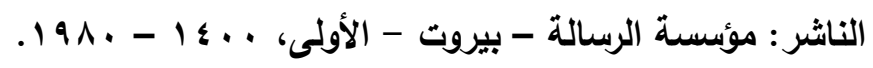

ابـ. تهذيب اللغة للأزهري تحقيق/ محمد عوض مرعب - دار إحياء التراث العربي ، بيروت

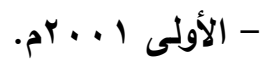

r r. التوضيح لثرح الجامع الصحيح لابن الملقن - المحقى: دار الفلاح للبحث العلمي

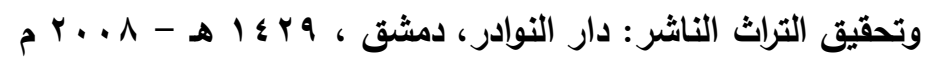

\section{هرف البيم}

بr. جمهرة اللغة لابن دريد - تحقيق/ رمزي منير بعلبكي - نشر/ دار العلم للملايين بيروت

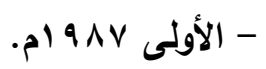

ـ ب. الجمل في النحو للخليل ـ تحقيق د/ فخر الاين قباوة - الخامسة ه999 ام.

\section{مرف الهاs}

هr. حاشية الصبان على شرح الأشموني على الألفية، نشر/ دار الكتب العلمية - بيروت

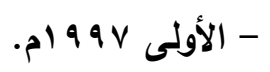

דr. حسن المحاضرة في أخبار مصر والقاهزة للسيوطي تحقيق/ محمد أبو الفضل إبراهيم

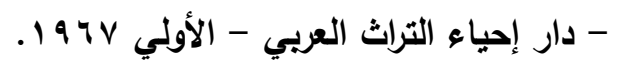

VV. الحطة في ذكر الصحاح الستة للقنوجي - ط/ دار الكتب العلمية ، ه19 ام. 
^r. لية الأولياء وطبقات الأصفياء لأبى نعيم الأصبهاني - الناشر: السعادة - مصر، . $97 \leq-8149 \leq$

\section{مرف النغاء}

qr. الخصائص لابن جنى، تحقيق /محمد علي النجار، ط/ الهيئة المصرية العامة للكتاب

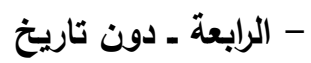

\section{هرف الدال}

•ـ. . دراسة الصوت اللغوي د/ أحمد مختار عمر ط/ عالم الكتب، القاهرة. اء. دراسات في فقه اللغة د/ صبح الصالح - نشر: دار العلم للملايين الطبعة الأولى

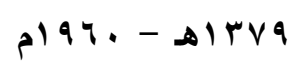

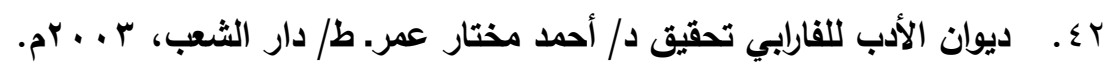

\section{هرف الراء}

بـ. الروض المعطار في خبر الأقطار للحميري تحقيق/ إحسان عباس الثانية . 91 ام.

\section{مرف السين}

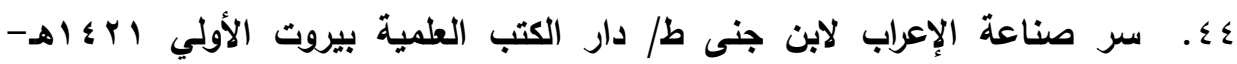
....

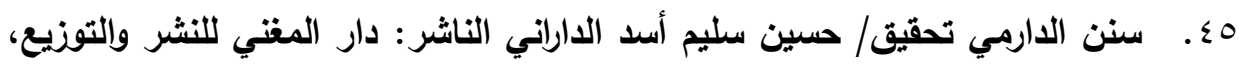

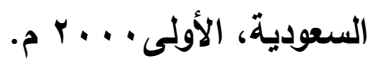

7 ـ. سير أعلام النبلاء للاهبي تحقيق/ مجموعة من المحققين ط/ مؤسسة الرسالة ،الثالثة .1910

\section{هرف الثمبـن}

ـV

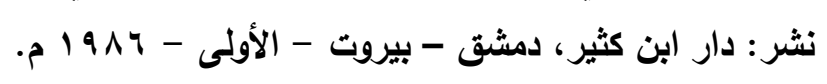

^ـ. شرح أبيات مغنى اللبيب لعبد القادر البغدادي - تحقيق /عبد العزيز رباح ورفاقه ط/ دار المأمون للتراث بيروت. 
9 . . شرح الحديث المقتفي في مبعث النبي المصطقى لأبي شامة، المحقق: جمال عزون

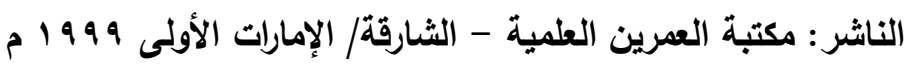

•. . . شرح السيوطي على صحيح مسلم تحقيق/ أبي اسحاق الحويني الأثري - الناشر : دار

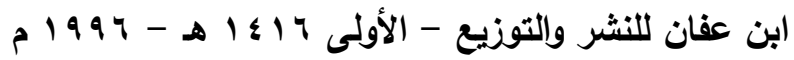

10. شرح شافية ابن الحاجب للرضى - تحقيق/ محمد نور الحسن ورفاقه - نشر: دار

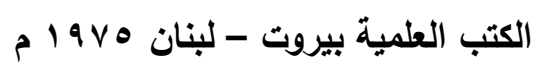

ro م. شرح صحيح البخاري لابن بطال تحقيق /أبي تميم ياسر بن إبراهيم دار النشر: مكتبة

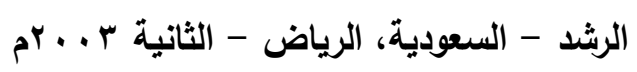

ro. شرح الفصيح لابن هشام تحقيق د/ مهذى عبيد جاسم - الأولى 911 ام ـه. شرح المشكاة للطيبي - المحقق: د. عبد الحميد هنداوي - الناشر: مكتبة نزار

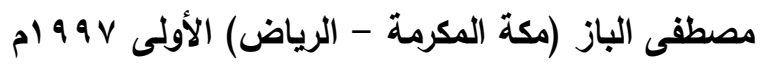

0. شرح مشكل الآثار للطحاوي تحقيق/شعيب الأرنؤوط الناشر : مؤسسة الرسالة - الأولى لـ . $1 \leq 9 \leq-$

40. شرح مصابيح السنة لابن الملك - تحقيق/ جماعة من المحققين ط/ دار الثقافة

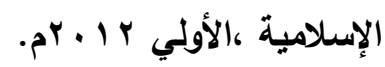

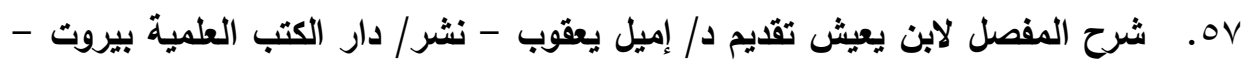

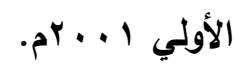

01. شرح النووي على صحيح مسلم الناشر: دار إحياء التراث العربي - بيروت ، الثانية، rar

ه. شمس العلوم ودواء كلام العرب من الكلوم لنشوان الحميري - تحقيق/د حسين ابن

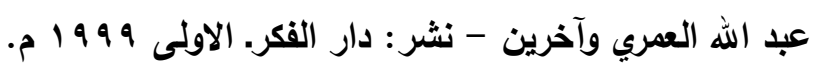

\section{مرف المساد}

• 7.

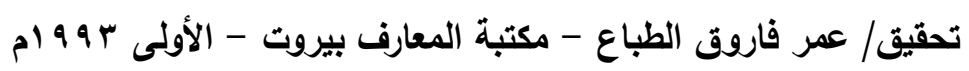


آ7. صحيح البخاري " الجامع المسند الصحيح المختصر من أمور رسول الله صلى الله عليه وسلم وسننه وأيامه " تحقيق: محمد زهير بن ناصر الناصر - الناشر : دار طوق

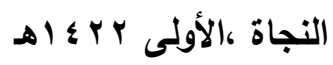

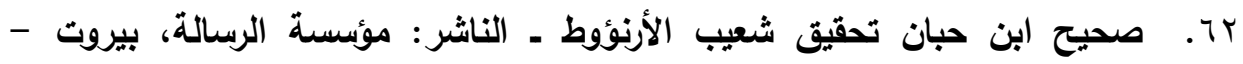

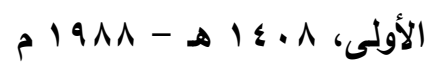

با7. صحيح مسلم - المسند الصحيح المختصر بنقل العدل عن العدل إلى رسول الله صلى الله عليه وسلم - تحقيق: محمد فؤاد عبد الباقي - الناشر: دار إحياء التراث العربي

$$
\text { - بيروت - }
$$

ع ا. صيانة صحيح مسلم لتقي الدين المعروف بابن الصلاح ، تحقيق/ موفق عبدالله

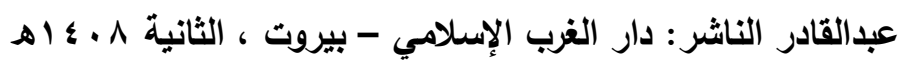

\section{مرف الطاء}

70. طبقات الحفاظ للسيوطي ط/ دار الكتب العلمية - بيروت الأولى، ب • ـ اهـ. 7T. طبقات الحنابلة لأبي يعلي - تحقيق/ محمد حامد الفقي - دار المعرفة بيروت. VV . . طبقات علماء الحديث لابن عبد الهادي، تحقيق/أكرم البوشي، وإبراهيم الزيبق الناشر :

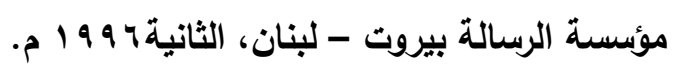

\section{هرف العين}

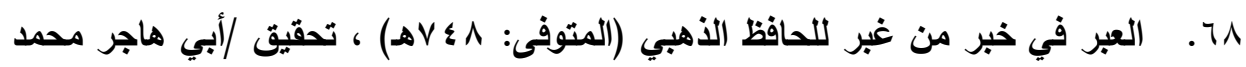

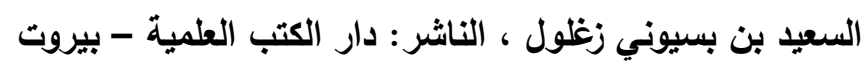
79. العدة في إعراب العمدة لابن فرحون - ط /مكتب الهاى بالدوحة - الأولى دون تاريخ. • . . . علم اللغة مقدمة للقارئ العربي د/ محمود السعران ط/ دار الفكر العربي، الثانية . $199 \mathrm{~V}$

V . عمدة القاري شرح صحيح البخاري للعيني الناثر : دار إحياء التراث العربي - بيروت r r العين للخليل بن أحمد الفراهيدي - تحقيق د/ مهذى المخزومي، ود/ إبراهيم السامرائي - نشر دار ومكتبة الهلال - دون تاريخ. 


\section{هرف الغين}

Vr. غريب الحديث لابن الجوزي تحقيق د/ عبد المطي أمين القلعجي نشر: دار الكتب

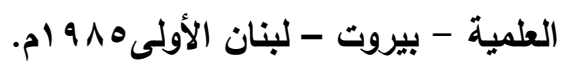

ع V . غريب الحديث للخطابي تحقيق/ عبد الكريم الغرباوي - ط/ دار الفكر دمشق

-p) $9 \wedge r$

هo . غريب الحديث لأبى عبيد تحقيق د/ محمد عبد المعيد خان ـ مطبعة دائرة المعارف

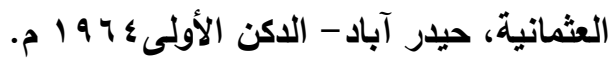

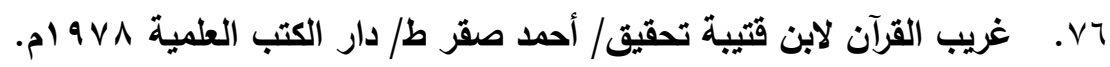

- الغريبين للهروي تحقيق/ أحمد فريد المزيدي - نشر/ مكتبة نزار مصطفى الباز . VV

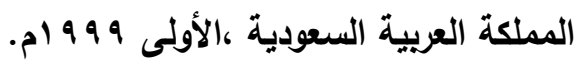

\section{مرف الفهاء}

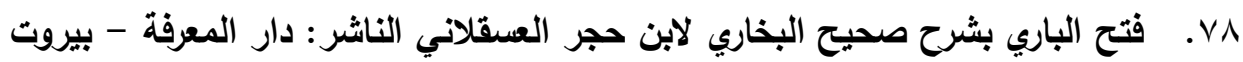
. Irva

و V9. فتح الكبير المتعال في إعراب المعلقات العشر الطوال لمحمد علي طه الدرة الناشر:

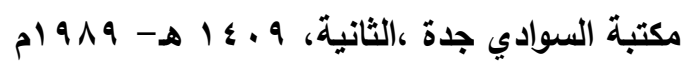

•. . فتح المنعم في شرح صحيح مسلم ،للاكتور موسى شاهين لاثين - الناشر: دار

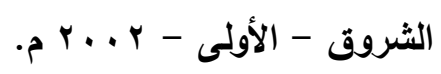

ا 1. فتح الودود في شرح سنن أبى داوود للسندي - تحقيق /محمد زكى الخولي - الأولي

$$
\text { . } 1 \text {. }
$$

r الفهرست لابن النديم - تحقيق/ إبراهيم رمضان - دار المعرفة بيروت - الثانية . $199 \mathrm{~V}$

rیم. في البحث الصوتي عند العرب د/ خليل إبراهيم العطية - نشر/ دار الجاحظ بغداد . $9 \wedge \mu$ عـ. في اللهجات العربية د/ إبراهيم أنيس - نشر/ مكتبة الأنجلو المصرية بالقاهرة - دون 


\section{هرف القاف}

هـ. القاموس المحيط للقيروزآبادي ـ تحقيق/ محمد نعيم العرقسوسي ـ ط/ مؤسسة الرسالة

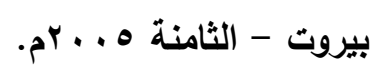

14. القبس في شرح موطأ مالك بن أنس لأبى بكر بن العربي الاشبيلي ،تحقيق/ د محمد

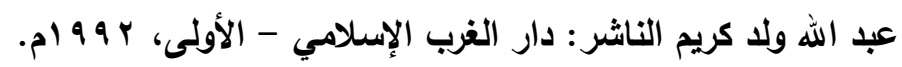
AV الخانجي بالقاهزة دون تاريخ.

1 ــ رة عين المحتاج في شرح مقدمة صحيح مسلم بن الحجاج للولوي ط/ دار ابن

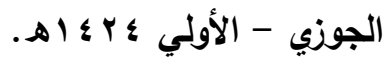

91. قلادة النحر في وفيات أعيان الدهر لابن بامخرمة - عُني به: أبو جمعة مكري ،وخالا

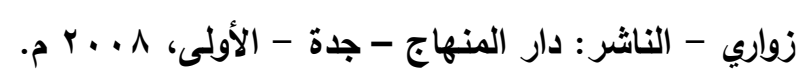

\section{هرف الكاف}

9. . الكتاب لسيبويه - تحقيق/ عبد السلام هارون - نشر مكتبة الخانجي - الثالثة

$$
\text { . }) 9 \wedge \wedge
$$

19. كثف المشكل من حديث الصحيحين لابن الجوزي - تحقيق/ علي حسين البواب -

$$
\text { الناشر: دار الوطن - الرياض. }
$$

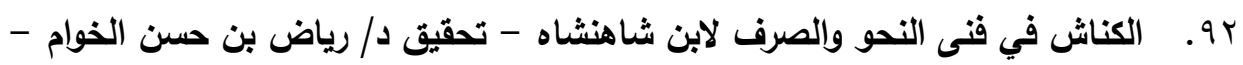

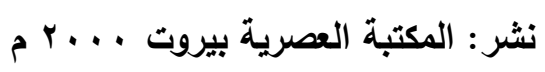

بو. الكوكب الوهاج شرح صحيح مسلم - لمحمد الأمين بن عبد الله الأُرَمي العََوَي، نشر:

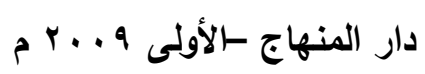

\section{مرف اللآم}

؟ . اللباب في تهذيب الأنساب لابن الأثير الجزري - نشر: دار صادر بيروت. 90 . لسان العرب لابن منظور ، ط/ دار صادر بيروت ، الثالثة ؛ إ؛ الهـ 
97 9. اللغة لجوزيف فندريس - تعريب: عبد الحميد الدواخلي، ومحمد القصاص - الناشر: مكتبة الأنجلو المصرية، ، 190 19 م.

V . . اللغة وعلم اللغة لجان ليونز ترجمة /مصطفى ذكي حسن التوني ، ط/ دار النهضة العربية دون تاريخ وعم العه نان

1. . اللامع الصبيح بشرح الجامع الصحيح لشمس الدين البرماوي تحقيق ودراسة: لجنة

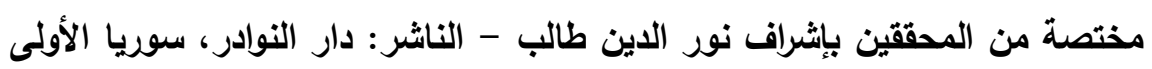

$$
\text { P. }
$$

9 9. لمعات التنقيح في شرح مشكاة المصابيح للادّلوي الحنفي ، تحقيق وتعليق/ الاكتور

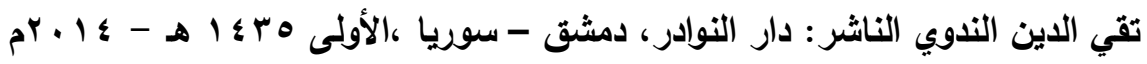

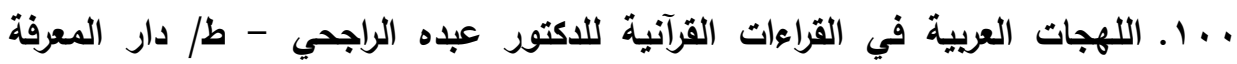

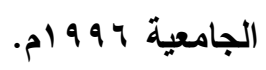

1. 1 ـ اللهجات العربية في كتاب سييويه أصواتا وينية د /صالح راشثد غنيم ب + ؛ أهـ

\section{هرف الميم}

r.1. مجمع بحار الأنوار في غرائب التزيل ولطائف الأخبار لمحمد طاهر ابن علي الكجراتي

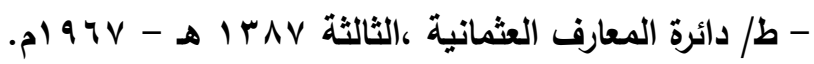
r. 1. المحكم والمحيط الأعظم لابن سيده - تحقيق/ عبد الحميد هنداوي - نثر: دار الكتب

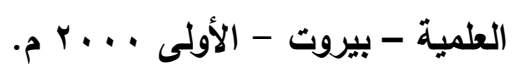

ـ ـ ا ـ المدخل إلى علم اللفة ومناهج البحث د/ رمضان عبد التواب - نشر/ مكتبة الخانجي

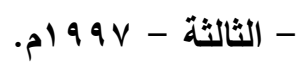

ه ـ ا ـ مرقاة المفاتيح شرح مشكاة المصابيح للملا على القاري الناشر: دار الفكر، بيروت -

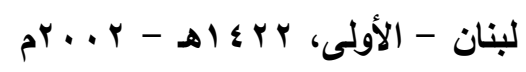

7. 1 ـ المزهر في علوم اللغة وأنواعها للسيوطي - تحقيق /فؤاد علي منصور - نثر: دار

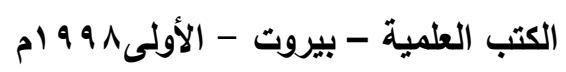

V. ا. مسند إسحاق بن راهويه ، تحقيق/ د. عبد الغفور بن عبد الحق البلوشي - الناشر:

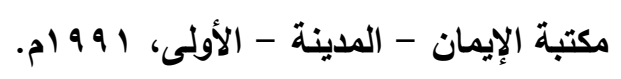


1 ـ ا ـ مسند الإمام أحمدبن حنبل - تحقيق/شعيب الأرنؤوط ، وعادل مرشد، وآخرين الناشر :

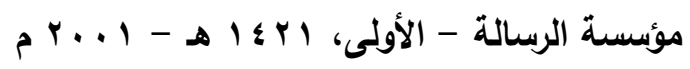

9 ـ 1 ـ مشارق الأنوار على صحاح الآثار للقاضي عياض - نشر المكتبة العتيقة. •11.

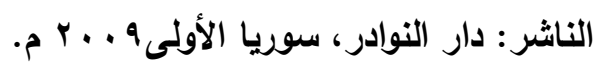

111 المصباح المنير في غريب الثرح الكبير للفيومي - ط/ المكتبة العلمية بيروت r Iا . مصنف ابن أبى شيبة تحقيق/ كمال يوسف الحوت الناشر: مكتبة الرشد - الرياض -

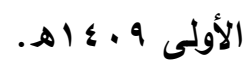

rا11. مطالع الأنوار على صحاح الآثار لابن قرقول ـ تحقيق: دار الفلاح للبحث العلمي

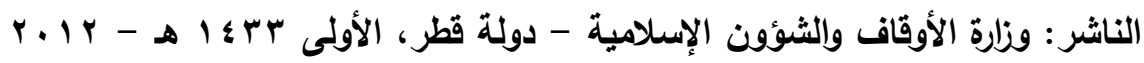

ع ا1 ـ معالم السنن للخطابي ط/ المطبعة العلمية بحلب - الأولي بr ب ام. 110

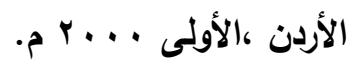

ד11. معانى القرآن للفراء - تحقيق/ محمد علي النجار ورفاقه ـ الناشر: دار المصرية للتأليف والترجمة - مصر ـ الأولى - دون تاريخ.

VIV . . معجم قبائل العرب لعمر رضا كحالة ـ الناشر: مؤسسة الرسالة، بيروت - السابعة،

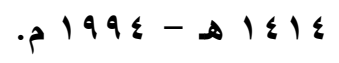

111. المعجم الكبير للطبراني - تحقيق/ حمدي بن عبد المجيد السلقي - دار النشر: مكتبة

$$
\text { ابن تيمية - القاهرة - الثانية. }
$$

19 11. المُعْلم بفوائد مسلم لمحمد بن علي التَّيمِي المازري المحقق: فضيلة الشيخ محمد

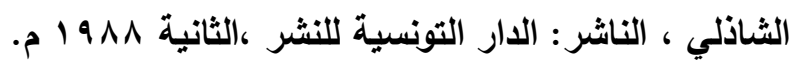

• rا. . مغتى اللبيب عن كتب الأعاريب لابن هشام ـ تحقيق د/ مازن المبارك، ط/ دار الفكر

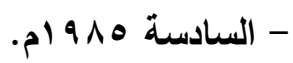


اY I ـ المفاتيح في شرح المصابيح للحسين بن محمود المظهري تحقيق /لجنة مختصة من

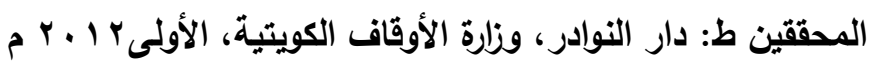

Tr ا ـ المفهم لما أثكل من تلخيص كتاب مسلم لأحمد بن عمر بن إبراهيم القرطبي تحقيق/

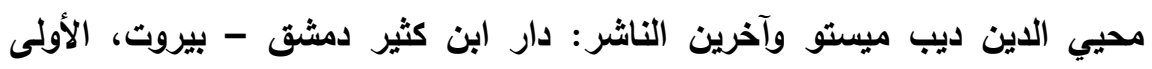

. 1999

ب ا ـ المقتضب للمبرد - تحقيق/ محمد عبد الخالق عظيمة. الناشر: عالم الكتب. - بيروت - دون تاريخ.

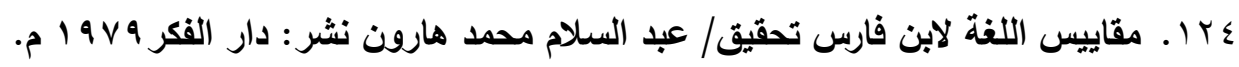

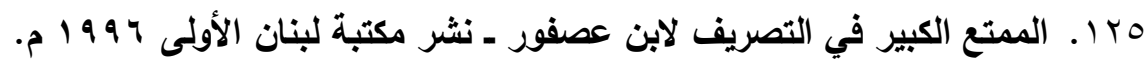
דrا. . موطأ الإمام مالك برواية محمد بن الحسن الثيباني - تحقيق: عبد الوهاب عبد اللطيف الناشر: المكتبة العلمية، الثانية.

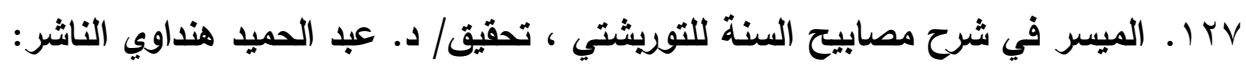

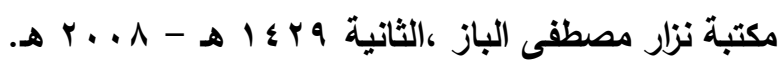

\section{هرف النون}

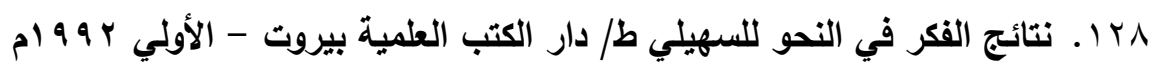
وץ1. نفح الطيب من غصن الأندلس الرطيب لثهاب الدين أحمد بن محمد التلمساني ، تحقيق /إحسان عباس ،الناشر : دار صادر - بيروت.

• با. النهاية في غريب الحديث لابن الأثير - تحقيق/ طاهر احمد الزاوي، محمود محمد

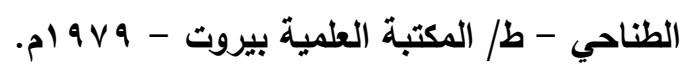

\section{هرف الهواو}

اس ا. وفيات الأعيان وأنباء أبناء الزمان لابن خلكان ـ تحقيق/ إحسان عباس ط/ دار صـادر بيروت. 